\title{
QUANTIFICATION AND CHARACTERIZATION OF PARTICULATE MATTER GENERATED FROM UNPAVED ROADS IN THE OIL DEVELOPMENT AREA OF WESTERN NORTH DAKOTA
}

\author{
A Thesis \\ Submitted to the Graduate Faculty \\ of the \\ North Dakota State University \\ of Agriculture and Applied Science
}

By

Sumon Datta

In Partial Fulfillment of the Requirements

for the Degree of MASTER OF SCIENCE

Major Department

Agricultural and Biosystems Engineering

November 2016

Fargo, North Dakota 


\section{North Dakota State University \\ Graduate School}

Title

QUANTIFICATION AND CHARACTERIZATION OF PARTICULATE

MATTER GENERATED FROM UNPAVED ROADS IN THE OIL

DEVELOPMENT AREA OF WESTERN NORTH DAKOTA

By

Sumon Datta

The Supervisory Committee certifies that this disquisition complies with North Dakota

State University's regulations and meets the accepted standards for the degree of

MASTER OF SCIENCE

SUPERVISORY COMMITTEE:

Dr. Shafiqur Rahman

Chair

Dr. Bernhardt Saini-Eidukat

Dr. Larry Cihacek

Approved:

$11 / 16 / 2016$

Date
Dr. Sreekala Bajwa

Department Chair 


\begin{abstract}
Western North Dakota, USA is experiencing particulate matter (PM) emissions, especially coarse $\left(\mathrm{PM}_{10}\right)$ and fine $\left(\mathrm{PM}_{2.5}\right)$, due to heavy traffic on unpaved roads from rapid oil development. Particulate matters may affect human and animal health, as well as soil quality. Thus, the purpose of this research was to quantify and characterize PM. Particulate matter samples were collected using miniVOL ${ }^{\mathrm{TM}}$ portable air samplers in the pre-conditioned quartz filters which were characterized using Scanning Electron Microscopy (SEM), Electron Dispersive Spectrometry (EDS). The pooled average $\mathrm{PM}_{10}$ concentrations varied between 30.84 \pm 14.19 to $70.42 \pm 38.37 \mu \mathrm{g} / \mathrm{m}^{3}$ and $\mathrm{PM}_{2.5}$ concentrations varied between $14.08 \pm 6.56 \mu \mathrm{g} / \mathrm{m}^{3}$ to $19.60 \pm 7.51 \mu \mathrm{g} / \mathrm{m}^{3}$. SEM and EDS analysis revealed that most of the particulates were quartz (46\%), followed by silicates $(36 \%)$, biogenic particles $(9 \%)$, etc. Soil analysis revealed that the average concentrations of most of the metals were below the reference level except mercury and lead.
\end{abstract}




\section{ACKNOWLEDGEMENTS}

Firstly, I would like to express my deepest appreciation to my committee chair, Associate Professor Dr. Shafiqur Rahman, who has the attitude and the substance of a genius: he continually and convincingly conveyed a spirit of adventure in regard to research. Without his help, guidance and persistent help, this thesis would not have been possible. His unwavering enthusiasm kept me constantly engaged with my research and his personal generosity helped make my time at North Dakota State University more enjoyable.

I would like to express my deepest gratitude to my committee members, Associate Professor Dr. Bernhardt Saini-Eidukat and Associate Professor Larry Cihacek for their valuable suggestions, directions, continuous support with the research and sampling. Their concise mentoring and encouragement have been especially endearing.

Special thanks goes to Dr. Saidul Borhan for his unceasing support over the research duration with the field sampling, for his valuable comments on processes and also who had to bear a heavy load of responsibility and concern in bringing this thesis to a successful end, indeed in selfless spirit.

I would also like to thank Dr. Kris Ringwall of Dickinson Research Extension Center for providing lodging during sampling and also, his continuous support over the research duration.

I would like to take this opportunity to acknowledge this research funding by North Dakota State University Dust Research fund and I would also like to acknowledge the services of Electron Microscopy Lab, NDSU and Center for Nanoscale Research Lab (CNSE) for allowing us to use their facilities. 


\section{DEDICATION}

This thesis is dedicated to my parents and my wife 


\section{TABLE OF CONTENTS}

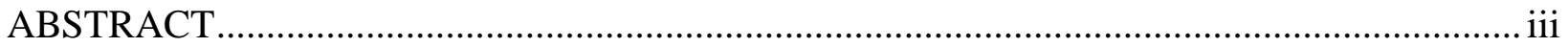

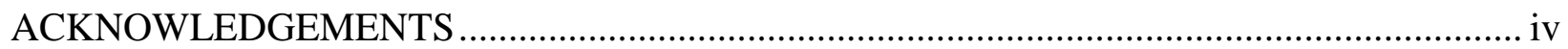

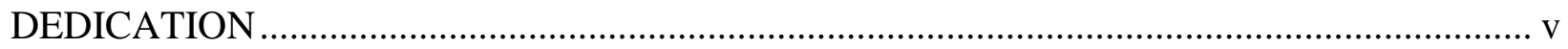

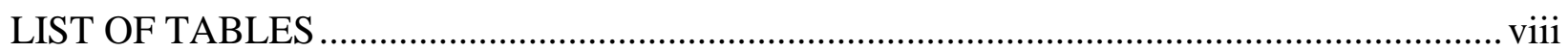

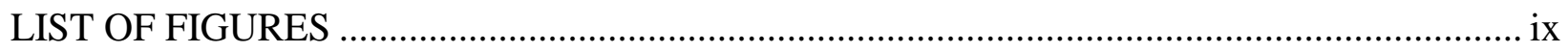

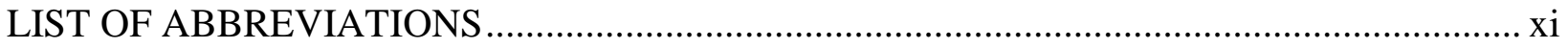

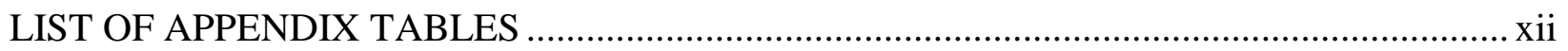

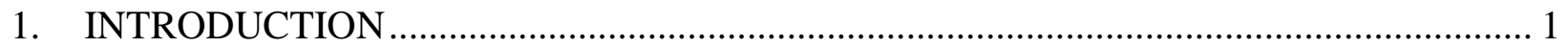

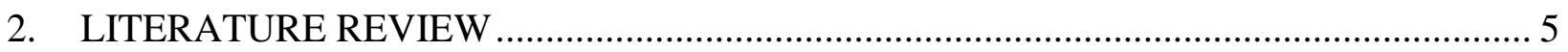

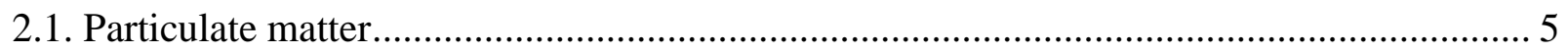

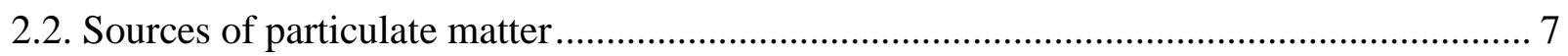

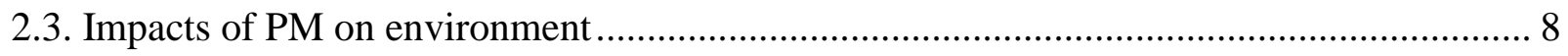

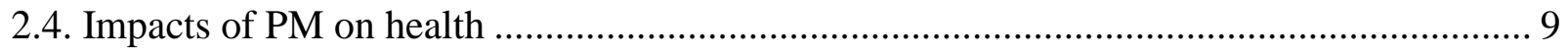

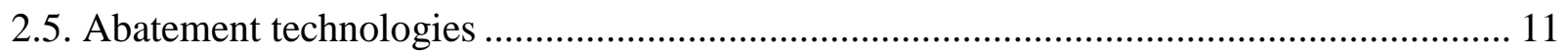

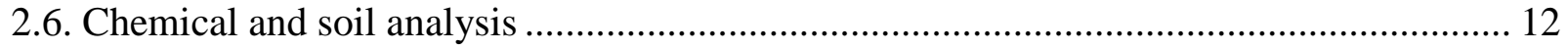

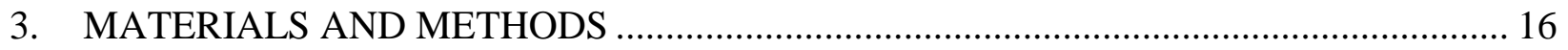

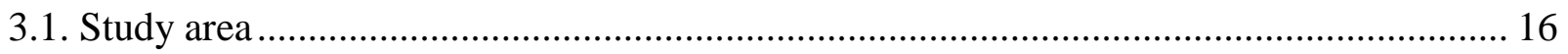

3.2. Particulate matter sampling and calculation of PM concentration..................................... 18

3.2.1. Airmetrics portable air sampler instrument ........................................................... 18

3.2.2. Filter preparation and conditioning, and setup .................................................. 20

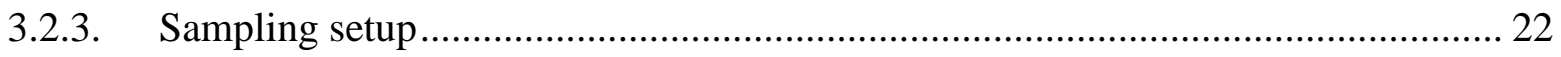

3.2.4. Meteorological data ………………………................................................. 23

3.2.5. Vehicle tracking ................................................................................................... 24

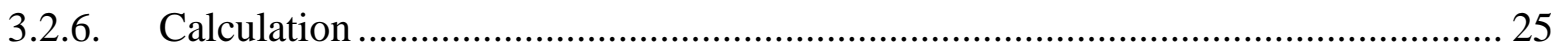




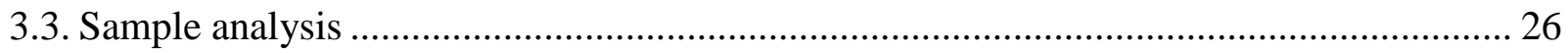

3.3.1. Identification of mineral phase from SEM results ............................................... 27

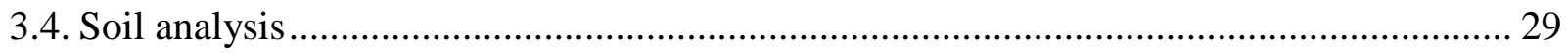

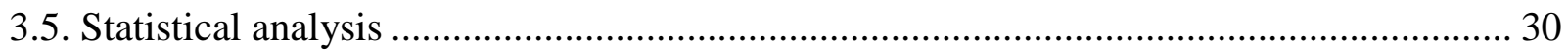

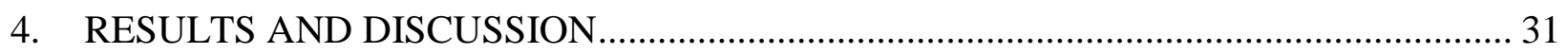

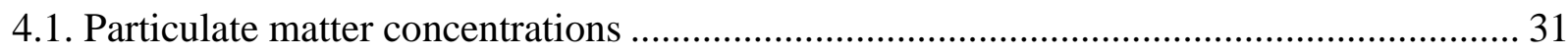

4.2. Mineralogical characterization of particulate matter........................................................... 39

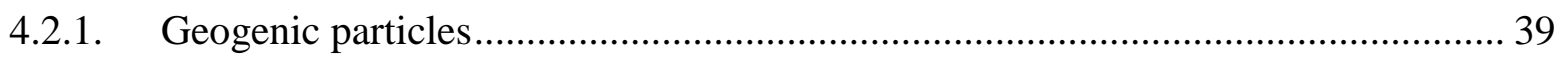

4.2.2. Anthropogenic particles ……………………................................................. 42

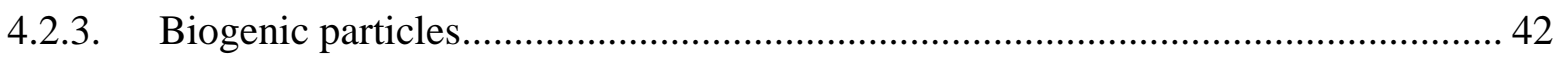

4.2.4. Relative amounts of identified particles ............................................................. 44

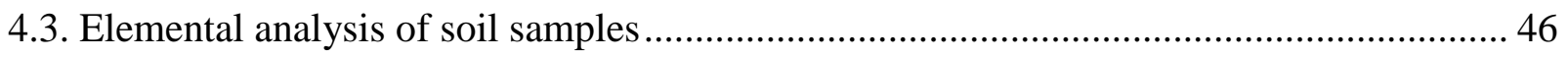

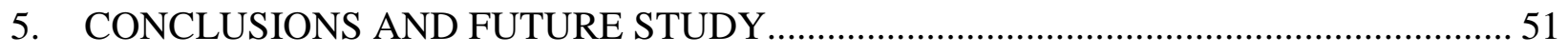

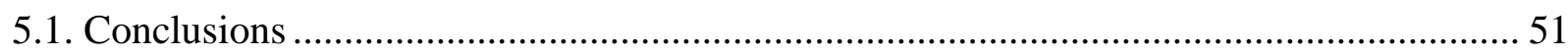

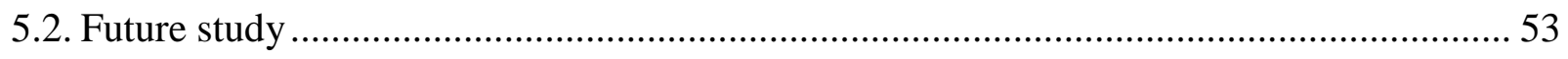

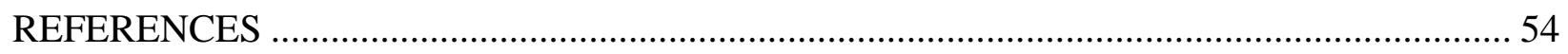

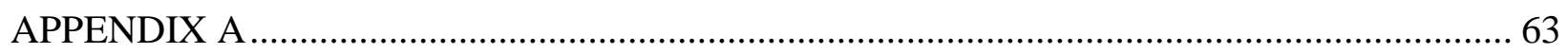

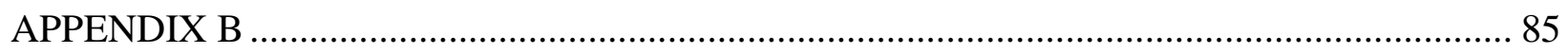

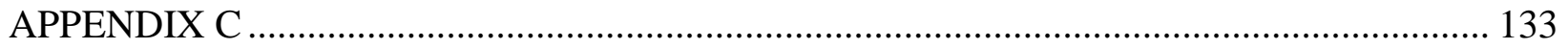




\section{LIST OF TABLES}

Table $\underline{\text { Page }}$

1. Weather Profile near DREC Ranch near Manning, ND - North Dakota Agricultural Weather Network (NDAWN) .................................................................................. 18

2. Stepwise regression analysis results of PM concentrations at site 1 ................................... 33

3. Stepwise regression analysis results of PM concentrations at site 2 ................................. 36 


\section{LIST OF FIGURES}

$\underline{\text { Figure }}$

$\underline{\text { Page }}$

1. Oil fields and oil rigs locations in North Dakota (Source: www.dmr.gov.nd) ..... 1

2. Size comparison of PM particles (USEPA, 2016) ............................................................ 6

3. Sampling locations at Manning Ranch (Blue boxes) (Approximately within 5 kilometers

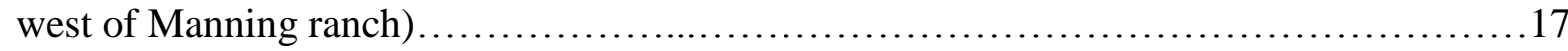

4. Map of the new sampling location (Red section is control with no additives, yellow section is brine-treated, blue section is magnesium chloride treated) (Approximately 15 kilometers east of Manning Ranch)......

5. Schematic diagram and combination of impactor of the TAS (; a. exterior of sampler, b. interior of sampler, a. PM10 impactor assembly, b. PM2.5 impactor assembly (Airmetrics, Springfield, OR, USA) Photos taken from Airmetrics MiniVol' ${ }^{\mathrm{TM}}$ TAS Manual - www.airmetrics.com)

6. MiniVol ${ }^{\mathrm{TM}}$ Portable Air Sampler in operation at site \#1 (vertically mounted) 20

7. a. Sartorius CP2P Microbalance at CNSE Lab, NDSU; b. Millipore Quartz Filters while being conditioned.

8. Experimental Setup of different locations: a. experimental setup at site \#1; b. experimental design at site \#2; c. experimental design at site 3.

9. Onset Hobo Data Logger (H21-002) (Partially taken from Onset Website www.onsetcomp.com)

10. Simmons Camera (deployed in site \#2).

11. Sample Preparation for SEM analysis: a. small sections cut from filter; b. sections placed on carbon tape on cylindrical mounts

12. Calculation of possible mineral/phase group from SEM data (Quartz)........................... 28

13. Calculating possible complex mineral formulas from SEM data (Aluminosilicates) ............ 29

14. Average PM concentrations with respect to traffic and rainfall at site 1 ........................... 31

15. Average PM concentrations on June 28-30, 2016 exceeding NAAQS value with respect to sampling locations at site $1(\mathrm{~N}-12$ refers to north side sampler at $12 \mathrm{~m}$ distance from the center of the road).

16. Yearly average PM concentrations at site 1 .... 32

17. Average PM concentrations with respect to traffic and rainfall at site 2 . 35 
18. Average PM concentrations on May 20-22, 2015 exceeding NAAQS value with respect to sampling locations at site $2(\mathrm{~N}-12$ refers to north side sampler at $12 \mathrm{~m}$ distance from the center of the road).

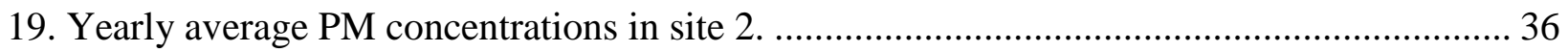

20. Average TSP concentrations in relation to types of treatments at site 3. ............................ 39

21. Particulate matter identification from actual samples (Quartz) ....................................... 40

22. Particulate matter identification from actual samples (Silicate minerals aluminosilicates)

23. Particulate matter identification from actual samples (Silicate minerals - oxides) 41

24. Particulate matter identification from actual samples (Anthropogenic minerals - soot) ....... 42

25. Particulate matter identification (Biological particles)

26. Relative amounts of minerals: (a) at all sites; (b) at site 1; (c) at site 2; (d) at site 1: $\mathrm{PM}_{10} ;(\mathrm{e})$ at site $1: \mathrm{PM}_{2.5} ;$ (f) at site 2: $\mathrm{PM}_{10} ;(\mathrm{g})$ at site $2: \mathrm{PM}_{2.5}$

27. (a) Average mercury $(\mathrm{Hg})$ concentrations in $\mathrm{ppm}$ in soil at varying distances from the road $(\mathrm{n}=8$ at $12 \mathrm{~m}, \mathrm{n}=6$ at $30 \mathrm{~m}, 60 \mathrm{~m}, 90 \mathrm{~m}) ;(\mathrm{b})$ Average mercury $(\mathrm{Hg})$ concentration in ppm with respect to the date of trip $(n=8$ for all sampling dates except, $n=6$ for April 20-22, 2015).

28. (a) Average lead $(\mathrm{Pb})$ concentrations in ppm in soil at varying distances from the road $(\mathrm{N}=8$ at $12 \mathrm{~m}, \mathrm{~N}=6$ at $30 \mathrm{~m}, 60 \mathrm{~m}, 90 \mathrm{~m})$; (b) Average lead $(\mathrm{Pb})$ concentration in ppm with respect to the date of trip ( $n=8$ for all sampling dates except, $n=6$ for April 2022, 2015).

29. (a) Average nickel (Ni) concentrations in ppm in soil at varying distances from the $\operatorname{road}(\mathrm{N}=8$ at $12 \mathrm{~m}, \mathrm{~N}=6$ at $30 \mathrm{~m}, 60 \mathrm{~m}, 90 \mathrm{~m})$; (b) Average nickel (Ni) concentration in ppm with respect to the date of trip ( $n=8$ for all sampling dates except, $n=6$ for April 20-22, 2015).

30. (a) Average calcium $(\mathrm{Ca})$ concentrations in ppm in soil at varying distances from the $\operatorname{road}(\mathrm{N}=8$ at $12 \mathrm{~m}, \mathrm{~N}=6$ at $30 \mathrm{~m}, 60 \mathrm{~m}, 90 \mathrm{~m})$; (b) Average calcium $(\mathrm{Ca})$ concentration in ppm with respect to the date of trip $(n=8$ for all sampling dates except, $n=6$ for April 20-22, 2015). 


\section{LIST OF ABBREVIATIONS}

PM

Particulate matter.

USEPA United States Environmental Protection Agency.

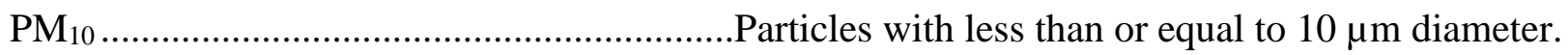

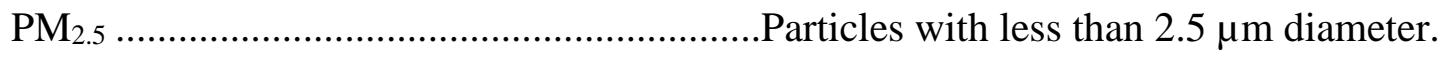

TSP ........................................................Total Suspended Particulate.

NAAQS ......................................................tional Ambient Air Quality Standards

USGS ....................................................United States Geological Survey. 


\section{LIST OF APPENDIX TABLES}

Table $\quad \underline{\text { Page }}$

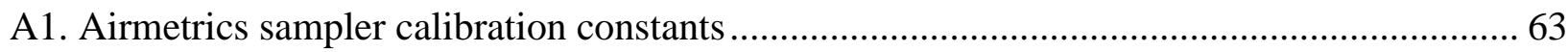

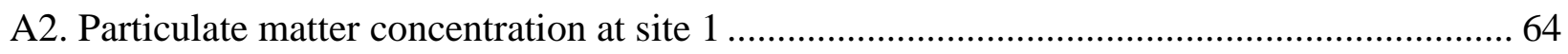

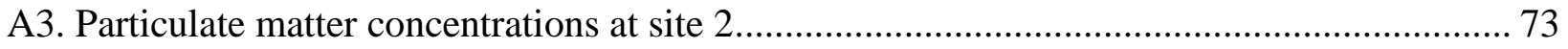

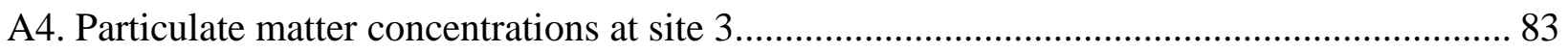

B1. Identification of filters with respect to their locations and sampling date ......................... 85

B2. Relative weight percentages of corresponding elements resulting from EDS analysis ........ 85

B3. Particulate matter type with respect to filters .............................................................. 101

B4. Particulate matter identification ......................................................................... 102

C1. Elemental compositions in soil samples (analyzed by ICP-MS) .................................. 133 


\section{INTRODUCTION}

North Dakota's oil production topped 1.1 million barrels per day in March, 2016 whereas this number was only 360 thousand barrels per day only five years ago in March, 2011. There are currently about 1600 oil wells active in North Dakota and 26 active drill rigs whereas there were 1271 active oil wells and 200 active drilling rigs in 2011 (Figure 1) (DMR, 2016) (USEIA, 2016). This significant increase in oil production has concurrently led an increase in oil rig activities and road traffic causing noticeable growth of airborne particulate matter in Western North Dakota. An oil well requires over 2,000 truck trips (1 truck carries 5460 gallons of oil) in its lifetime and these are driven mostly over unpaved roads in North Dakota (Dobb, 2013). This unpaved road traffic is a prime source of particulate matter (PM) which includes dust and has been recognized as criteria air pollutant due to its adverse impact on the environment and health (Mao et al., 2013).
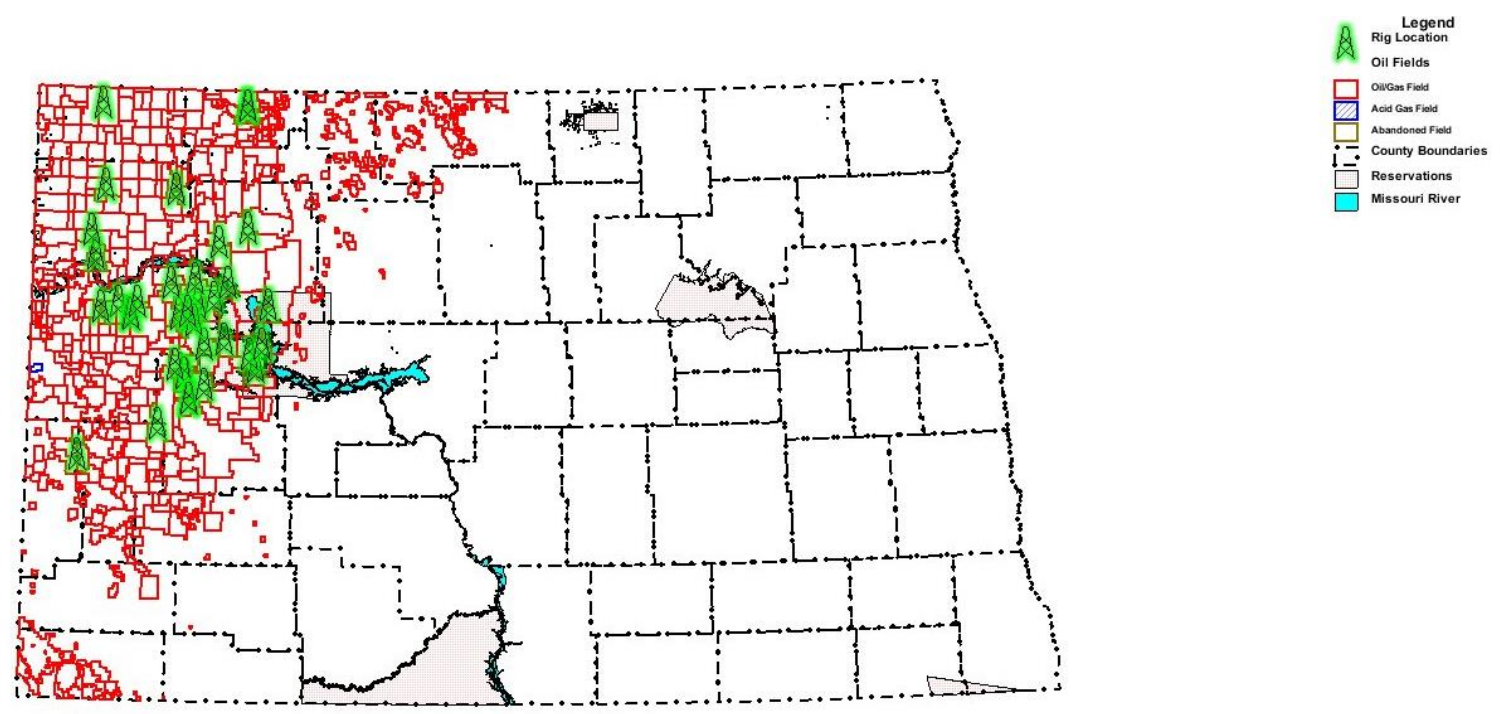

Figure 1. Oil fields and oil rigs locations in North Dakota (Source: www.dmr.gov.nd)

Particulate matter or dust particles can be of different types i.e., mineral dusts, metallic dusts, chemical dusts, organic and vegetable dusts, volcanic dusts, atmospheric dusts, cosmic dusts, etc. (IUPAC, 1990). Atmospheric or wind borne dust, also known as aeolian dust, comes 
from arid and dry regions where high velocity winds are able to remove mostly silt-sized material, deflating susceptible surfaces. This includes areas where grazing, ploughing, vehicle use, and other human activities have further destabilized the land, though not all source areas have been largely affected by anthropogenic impacts (Middleton \& Goudie, 2001).

Particulate matter constitutes a major class of air pollution and can be divided into two groups on basis of inhalable concern: fine particles $\left(\mathrm{PM}_{2.5}\right)$ and coarse particles $\left(\mathrm{PM}_{10}\right) . \mathrm{PM}_{2.5}$ results from fuel combustion from motor vehicles and power generation, while coarse particles $\left(\mathrm{PM}_{10}\right)$ are generally emitted due to vehicle traffic on unpaved roads, and materials handling, and as well as windblown dust. Inhalable PM includes both fine and coarse particles. Small particulates $\left(\mathrm{PM}_{2.5}\right)$ can be inhaled, resulting in respiratory diseases and often premature death (Donham \& Thelin, 2004; Gonzales et al., 2011; Pattey \& Qiu, 2012; Samet \& Krewski, 2007). $\mathrm{PM}_{2.5}$ from road surfaces is a significant source of air pollution (Gunawardana et al., 2012). These particles can enter and be deposited in the respiratory system and are associated with numerous health effects. Exposure to $\mathrm{PM}_{10}$ is primarily associated with the aggravation of respiratory conditions, such as asthma. In addition to health problems, PM is the major cause of reduced visibility, thus the safety concern. Dust may contain heavy metals and may be toxic to human, crop or animal health when their concentrations exceed certain thresholds (Guney et al., 2010). The amount of dust emissions from an unpaved road is dependent on amount of traffic, vehicle type, weight and speed of vehicle, wind speed and condition of the road (Mao et al., 2013).

Particulate matter can have both physical and chemical impacts on the vegetation grown alongside unpaved roads. Dust can physically block stomata of plants and chemical characteristics of dust may affect either soil or plants (Farmer, 1993). Dust cover on leaf surfaces 
may affect yield in a variety of ways, with the yield reduction depending upon the thickness of cover and to an extent, the type of plant (McCrea, 1984). The effect is likely to be greater on plants with young leaves as these retain a greater amount of dust, even after a moderate rainfall. Similarly, dust may carry and cause plant disease and increased pest infestation (Organic Life, 2015). Additionally, dust may also cause depressed appetite in livestock, which may result in a retarded growth rate of around $20 \%$ for each day the animal is kept on the contaminated pasture (McCrea, 1984). Long term exposure to dust or particulate matter to agricultural worker is likely to result in mild to chronic respiratory illness (Pattey \& Qiu, 2012). It is reasonable to postulate that oil field workers, truck drivers, and local residents may exhibit some respiratory symptoms. Therefore, it is important to quantify dust emission rates resulting from unpaved road traffic in oil development area to assist in the development of techniques or technologies to control dust from the source.

It is also beneficial to know the chemical composition and morphology of particles. This gives a better understanding about the origin of particles whether it is of anthropogenic or natural sources. Particulate matter deposited on soil by transportation by the wind or some other medium can be detrimental to health, thus negatively impacting soil quality in that region. Thus, it is necessary to quantify dust emissions and adapt appropriate technology to mitigate adverse environmental impacts. Keeping that in mind, the present work focused on to quantify diurnal dust emission due to vehicle traffic on an unpaved roads and their impact on soil health. The hypothesis of this study is that increased traffic activities in the oil development areas is likely to increase particulate matter emissions, thus may affect the soil quality.

The specific objectives of this study were:

1. To quantify $\mathrm{PM}_{10}$ and $\mathrm{PM}_{2.5}$ concentrations in the atmosphere, 
2. To quantify and characterize the mineral composition in the dust,

3. To quantify the impacts of dust on roadside soil and determine elemental composition of metals present in the soil. 


\section{LITERATURE REVIEW}

\subsection{Particulate matter}

Particulate matter $(\mathrm{PM})$ is a mixture of liquid and solid particles suspended in the air which is frequently used as a measurement of levels of atmospheric air pollution (Stanek et al., 2011). Some particles, such as dust, dirt, soot, or smoke, are large or dark enough for naked eyes to see while, others are so small that needs an electron microscope to be detected (USEPA, 2016). Dust is fine particulate matter removed from land surfaces by wind erosion and small enough to be suspended in atmosphere (Toy \& Foster, 2002). The size of these dust particles ranges from 1 to $100 \mu \mathrm{m}$ in diameter, and they settle slowly by gravity forces (IUPAC, 1990). In referring to a particle size of airborne dust, the term 'particle diameter' is not enough to describe the particle size as the geometric size of a particle does not explain how it behaves in its airborne state, rather 'particle aerodynamic diameter' is used. The particle aerodynamic diameter is the diameter of a hypothetical sphere with a density of $1000 \mathrm{~kg} / \mathrm{m}^{3}$ having the same terminal settling velocity in calm air as the particle in question, regardless of its geometric size, shape and true density. So, dust is characterized in size according to this aerodynamic diameter. Smaller particles tend to stay in the air for longer period of time and they can also travel farther. These particles may be inhaled into human respiratory tracts. Therefore, they pose a significant risk to human health if exposed to a higher concentration for a certain period of time. That's why PM is considered as one of the six criteria air pollutants by the United States Environmental Protection Agency (USEPA) (USEPA, 2015).

Many different terms are used to characterize the particles. Total Suspended Particulates (TSP) are the total airborne particles that are measured by a high volume sampler without a sizeselective inlet and an aerodynamic diameter which varies from 10 to $45 \mu \mathrm{m}$ (USDFR, 1999). 
Particulate matter can be classified into different terms. The most basic classification is based on size (i.e., coarse, and fine particles) expressed as concentration values. $\mathrm{PM}_{10}$ are inhalable particles with an aerodynamic diameter that are generally $10 \mu \mathrm{m}$ and smaller whereas, $\mathrm{PM}_{2.5}$ are fine inhalable particles with an aerodynamic diameter below $2.5 \mu \mathrm{m}$ (USEPA, 2015). USEPA continuously evaluates and revises the National Ambient Air Quality Standards (NAAQS) of $\mathrm{PM}_{10}$ and $\mathrm{PM}_{2.5}$ as required by the Clean Air Act (USEPA, 2015). NAAQS specifies that the $\mathrm{PM}_{10}$ should not exceed $150 \mu \mathrm{g} / \mathrm{m}^{3}$ for a period of 24 hours and $\mathrm{PM}_{2.5}$ should not exceed 35 $\mu \mathrm{g} / \mathrm{m}^{3}$ for a 24 -hour period. Geographic locations exceeding these standard values might pose concerns to the population living in that area by negatively impacting the public welfare. Figure 2 shows size comparisons for PM particles.

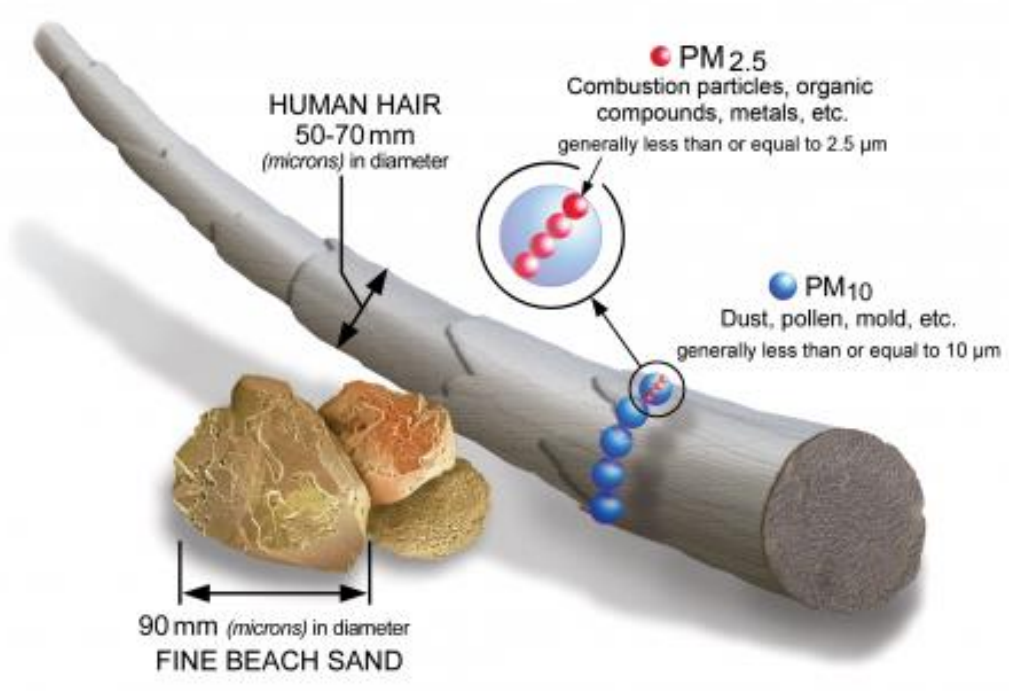

Figure 2. Size comparison of PM particles (USEPA, 2016)

Another classification of PM is based on the type of sources: primary and secondary particles. Primary particles result from various activities, such as: burning (smoke), dirt, road dust, industrial activities, spraying, and mold, pollen, etc. and then blown by the wind.

Secondary particles are smaller than primary particles and these are usually formed through chemical transformation of gases (Guttikunda, 2008). 
Numerous research studies have been carried out to quantify the particulate matter emission from different sources and its impacts on health. Thurston et al. (2011) conducted the first study in United States that used $\mathrm{PM}_{2.5}$ composition data from USEPA chemical speculation network (CSN) and applied multivariate methods to identify and quantify the $\mathrm{PM}_{2.5}$ by doing factor analysis. They identified PM sources, but, secondary aerosol constituents were not included in the source component identification factorization step. Their objective was to attribute the $\mathrm{PM}_{2.5}$ mass and avoided secondary aerosol factors. There are many environmental and man-made factors that affect the amount of PM concentrations in atmosphere. Kuhn et al. (2005) sampled road dust from vehicles, particularly PM, on the front and back of a vehicle's tire and they found a positive relationship between PM emission factor and vehicle speed.

\subsection{Sources of particulate matter}

Particulate matter can be generated from various sources such as - natural sources, anthropogenic sources, etc. Natural sources primarily include the erosion of soil by the wind. General wind-entrained soil particles fall into two distinct size ranges: the coarser fraction is mainly quartz grains which tend to deposit close to the source and the clay particles which is $<10$ $\mu \mathrm{m}$ and can get transported further in the air. Airborne particles can also accumulate from the evaporation of droplets of sea water which leaves suspended salt crystals in the atmosphere (Gunawardana et al., 2012). Other natural sources include volcanoes, spores, and pollen. These primary natural sources contribute to a global particle production rate of $4900 \times 10^{6}$ ton/year (Colls \& Tiwary, 2010).Other primary sources are biomass, wood,. and vegetative burning, vehicle emissions, secondary aerosols, etc.

Secondary aerosols are formed by photochemical, chemical and man-made processes and are known to be major constituents of fine particulate matter measured in most industrialized 
zones. All activities such as combustion, melting, grinding, crushing, ploughing or spraying produce particles; a variable portion of these will be fine enough to stay suspended in the atmosphere (Fuzzi et al., 2015). Oil combustion and diesel emissions from road transport are also major sources of PM emission. Particulate matter composition reveals high concentrations of elements including Al, Ca, Fe, Ti and Si classified as re-suspended road dust (Vallius et al., 2003), crustal dust (Koçak et al., 2009) or dust from construction activities. These can be interpreted as anthropogenic sources of PM which have a widespread impact on public health (WHO, 1999). Squizzato et al. (2016) quantified $\mathrm{PM}_{1}$ (particles with aerodynamic diameter less than $1 \mu \mathrm{m}$ ) which provides better information on the anthropogenic fraction of PM pollution and found out 7 potential sources. Secondary inorganic aerosol (33\%) and biomass burning (33\%) were the major contributor followed by primary emissions, fossil fuel combustion, aged sulfate, road, traffic, and marine aerosols. Health impacts and environmental concerns are likely to depend on the PM sources and level of exposure.

\subsection{Impacts of PM on environment}

Particulate matter has various impacts on the environment. The emergence of air pollution as a public health issue in the 1950s led to the development of federally funded research programs which culminated into Clean Air Act and establishment of EPA in 1970. The mounting anecdotal evidence of PM's harmful effects on terrestrial and aquatic ecosystems launched acid rain as the first air pollution threat to the environment to receive international attention. Particulate matter also impairs vision which can lead to various dangers. Acid-forming aerosols have been found to limit the life expectancy of paints by causing discolorations, loss of gloss, and loss of thickness of the paint film layer. Various building stones and cement products are damaged from exposure to acid-forming aerosols (Riediker, 2007; Valavanidis et al., 2008). 
These aerosols, when finally deposited in aquatic systems, cause deaths in aquatic life. The higher the light scattering efficiency, the less light from any given object reaches an observer's eyes, decreasing visibility. The light-scattering efficiency differs considerably for fine and coarse particles, ranging from 2.4 to $3.1 \mathrm{~m}^{2} / \mathrm{g}$ for fine particles and 0.2 to $0.4 \mathrm{~m}^{2} / \mathrm{g}$ for coarse particles. So, this widespread impacts of PM are negatively affecting the environment and our life regularly (Guney et al., 2010; Princeton; Samet \& Krewski, 2007). However, the PM generated from vehicles in the oil development area of Western North Dakota are not well quantified and their impact on the health, soil and crops are not well documented.

\subsection{Impacts of PM on health}

Particulate matter is known to adversely affect human health by deep penetration into alveolar regions of lungs where it can diffuse into the circulatory system and accumulate in vital organs such as liver, brain, heart, etc. (Campbell et al., 2005). A limited number of epidemiologic studies have evaluated the linkages between $\mathrm{PM}_{2.5}$ factors and health outcomes with a focus on mortality. PM sources i.e., crustal/soil/road dust have been linked directly to cardiovascular effects (Gong et al., 2003; Lanki et al., 2006). According to Valavanidis et al. (2008), fine particulate matter causes toxicity in human as they can penetrate deeper into the respiratory tract airways. Fine particulate matter $\left(\mathrm{PM}_{2.5}\right)$ exposure in the ambient air increases daily deaths and hospitalization for cardiovascular diseases (Schwartz et al., 2002) (Ballester et

al., 2001). Kim et al. (2016) investigated the association between prenatal and postnatal exposure to $\mathrm{PM}_{10}$ and children's weight from birth to 60 months of age. It was determined that air pollution may delay growth in early childhood and exposure to air pollution may be more harmful to children when their birth weight is low. Volk et al. (2013) found that exposure to traffic-related air pollution, nitrogen dioxide, $\mathrm{PM}_{2.5}$, and $\mathrm{PM}_{10}$ during pregnancy and during the 
first year of life was associated with autism. Further epidemiological and toxicological examinations of likely biological pathways will help determine whether these associations are causal.

These particles also promote the development of atherosclerosis (Künzli et al., 2005). It is estimated that an excess of 800,000 deaths each year may be attributed to particulate matter air pollution each year (WHO, 1999), secondary to myocardial infraction, life-threatening arrhythmias, or heart failure (Brook et al., 2004). Schwartz (1994) investigated the relationship between PM and hospital admissions for the elderly in Minneapolis-St. Paul, MN and collected data for persons who were 65 years or older for a period of 3 years (1986-1989). He looked for chronic obstructive pulmonary disease and for pneumonia. Time trends, weather, and seasonal fluctuations were three factors controlled by Poisson regression. $\mathrm{PM}_{10}$ and ozone were risk factors for pneumonia admissions and $\mathrm{PM}_{10}$ was solely responsible for obstructive pulmonary disease admissions. Hefflin et al. (1994) studied the effects of dust storms and respiratory diseases in southeast Washington State during October 1991. $\mathrm{PM}_{10}$ levels exceeded $1000 \mu \mathrm{g} / \mathrm{m}^{3}$ which is about 6-7 times greater than the EPA standard for 24-hour value. Emergency room visits for bronchitis were slightly increased, estimated at $3.5 \%$ per $100 \mu \mathrm{g} / \mathrm{m}^{3}$ increase in $\mathrm{PM}_{10}$. Naturally occurring $\mathrm{PM}_{10}$ has a weaker effect on the respiratory health than $\mathrm{PM}_{10}$ that resulted from anthropogenic sources.

Particles of motor vehicle origin appear to be potent in increased mortality (Lanki et al., 2006; Schwartz et al., 2002). Microenvironments represented by vehicles produces a pathway for the air pollutants from mobile sources to expose to humans (Riediker, 2007). Less consistency was observed in associations between PM sources and respiratory health effects which may be due to a limited number of studies. But there is some evidence for associations with a $\mathrm{PM}_{2.5}$ 
secondary sulfate factors. So, the negative impacts of PM on human health is significant enough to encourage further studies in the context.

\subsection{Abatement technologies}

Airborne particulate matter emissions can be minimized by pollution prevention and emission control measures. Prevention is more cost-effective than control. Approaches include management, choice of fuel, choice of technology and processes, fuel cleaning, use of natural shelter belts, buffers, etc. (Group, 1998). By improving combustion efficiency in vehicles, the amount of products of incomplete combustion, PM can be significantly reduced. PM can also be reduced by choosing cleaner fuels. Natural gas used as fuel emits much less particulate matter (WHO, 1999). Also, reduction of ash by fuel cleaning procedure can also reduce PM.

Sedimentation is used for comparatively larger particles with an aerodynamic diameter more than $20 \mu \mathrm{m}$ that works by regimenting the particles under gravity to a large volume chamber. For particles less than $20 \mu \mathrm{m}$ aerodynamic diameter, a cyclone separator is used. These cyclone separators are cheap, reliable, straightforward devices used as pre-cleaners.

Apart from that, emission control technologies have existed for a long time. Inertial or impingement separators collects medium-size and coarse particles. Electrostatic precipitators' collection efficiency is over $99 \%$ and they effectively reduce dust loading (Moore, 1994). Fabric filters - baghouses are another option for control of PM emissions which can be used in industries (efficiency $=99.9 \%$ at $0.1 \mu \mathrm{m}$ ). Wet scrubbers rely on a liquid spray to remove dust particles from a gas stream. It is used where the contaminant cannot be removed easily in a dry form, soluble gases and wettable particles are present, and the contaminant will undergo some subsequent wet process. Krasowsky et al. (2015) quantified PM emission from in-use locomotives along with black carbon (BC), particle number, $\mathrm{PM}_{2.5}$, and lung-deposited surface 
area (LDSA) and suggested LDSA as a potentially important health-relevant metric for nearsource exposures.

There are numerous mitigation practices that are being practiced around the world. The objective of mitigation is to reduce dust on the roads as well as maintaining a viable application cost at all seasons. Cavanagh (2006) proposed the design of roadside vegetation having the potential to capture road generated air pollution but no design features like tree width, tree height, etc. were given in the study. In cases of road dust mitigation by chemicals, a study done by Schwindt (2013) revealed that magnesium chloride is most commonly used and the most costeffective form of treatment. It effectively reduces dust but the dry conditions in summer reduces its efficiency. Calcium chloride has effectiveness similar to magnesium chloride, but it is costlier and its effectiveness depends on the dryness. Calcium chloride with polymers which is called 'Durablend' is also used for controlling dust. Wisp is a synthetic oil that provided slight dust reduction for a very short period of time. Rhino snot is an acrylic copolymer that increased the hardness of the road and provided limited amount of dust control. Coherex is a petroleum emulsion that provided veneer to the surface of the road controlling dust until the veneer started breaking up due to traffic. 'Durabond' is lignin with additives that provides a veneer to the surface of the road. Brine water (reject from oil extraction activities) which consists of $20 \%$ salt (primarily sodium chloride) is also used to control dusts, but its impacts to the environment, especially salinity, are not well documented. However, brine water is free and has a very low application cost. One visual study reveals that it is effective in reducing dust (Schwindt, 2013).

\subsection{Chemical and soil analysis}

In recent years, there has been significant emphasis on physical (size and morphology) and chemical (composition) characterization of individual atmospheric particles due to their 
effect on chemical properties which may impact human health, soil health, animal health and thus, the environment. Detailed characterization of individual particles provides useful information about their atmospheric history, sources, reactivity, formation, transport and removal of atmospheric chemical species (Adachi \& Tainosho, 2004; Li et al., 2010; Sen-lin et al., 2006). Scanning Electron Microscopy (SEM) along with Energy Dispersive X-Ray Spectroscopy (EDS) is commonly used for single particle study which provides particle morphology, elemental composition, and particle density of aerosols (Shi et al., 2003). It also gives better understanding about the origin of particles whether it is anthropogenic or natural.

In a study conducted in Beijing, China, Sen-lin et al. (2006) characterized mineralogy of certain airborne particulate matter $\left(\mathrm{PM}_{10}\right)$ by SEM/EDX and identified 38 minerals. Clay minerals were leading in the composition (30.1\%). Annual average of quartz, calcite, compound particulates, carbonates were $13.5 \%, 10.9 \%, 11.95 \%, 10.31 \%$, respectively. Čabanova et al. (2012) collected samples near a crosswalk of a busy road and near the parking place, and did chemical and phase analysis on them. The samples were characterized by a combination of analytical and microscopic techniques. SEM/EDS were used for characterizing morphology and size of particles and a total carbon analyzer was used for carbon. Fourier Transform Infrared Spectroscopy and Raman micro-spectroscopy were used for determining phase composition of dust samples. Major compounds were quartz, calcium aluminum silicate, and crystalline carbon.

Gunawardana et al. (2012) collected samples from Gold Coast, Southeast Queensland, Australia from different land uses and backgrounds. They analyzed the mineralogy and morphology of dust samples which were collected using a dry and wet vacuuming system. Results showed that $60 \%$ of the samples were quartz, clay, albite, microcline, chlorite, and 
muscovite. It had $2 \%$ organic matter and $30 \%$ potential pollutants. This large ratio of pollutants can have significant impact on the atmospheric aerosol content.

Inductively coupled plasma-mass spectrometry (ICP-MS) is considered attractive and one of the most sensitive techniques for the multi-elemental analysis of trace metals in various environmental samples. This technique usually requires a transformation (extraction) of the samples into solution before analysis. Using ICP-MS apparatus, the detection limits for trace metals can be down to sub-ppt or picomol/L levels in simple matrix solutions (Ahmed et al.; Dolan et al., 1990). The chemistry of PM is important as the particles may carry heavy metal and elements that are fine enough, so that they get attached with aerosols and they may travel further (Farmer, 1993). Studies suggest that heavy metals may be concentrated within the first few meters from the road and their concentration sharply decreases with distance from the center of the road (Blok, 2005; Guney et al., 2010). If heavy metals are deposited on agricultural crops due to off-road traffic, it may impact crop productivity and soil quality as well as the quality of crop productivity. Therefore, it is critically important to monitor soil quality next to oil development area. However, limited information is available on dust quantification and characterization in the Western North Dakota, USA and their impact on soil health.

Todhunter and Cihacek (1999) investigated the historical frequency of airborne dust in the Red River Valley, USA, however, they did not quantify the PM in their study. They reported the number of airborne dust events in the Red River Valley from 1948 to 1994. Ljepoja (2015) conducted a limited dust sampling in the Western North Dakota, but didn't factor in environmental parameters and vehicle traffic. It is important to consider weather conditions, road conditions, and vehicle traffic while quantifying dust emission. At the same time, suitable management practices are needed to minimize dust emission. 
Also, Schwindt (2013) conducted a dust mitigation study with different types of suppressants, but this study was limited to observation, no real quantification was carried out. This is why it is necessary to quantify and characterize the PM emissions in the Western North Dakota to adapt suitable management practices to minimize health and environmental impacts. 


\section{MATERIALS AND METHODS}

\subsection{Study area}

This study was conducted near the North Dakota State University Dickinson Research Extension Center Manning Ranch Headquarters (Latitude: $47^{\circ} 12^{\prime} \mathrm{N}$, Longitude: $102^{\circ} 50^{\prime} \mathrm{W}$ ), located in Dunn County about 35 kilometers north of Dickinson and 5 kilometers west of Manning, North Dakota, USA (Figure 3) (Site 1 and 2). Site 1, at the first location, was approximately 7 kilometers away from site 2. Another test location (Site 3) (Latitude: $47^{\circ} 12^{\prime} 45.6^{\prime \prime} \mathrm{N}$, Longitude: $102^{\circ} 36^{\prime} 16.7^{\prime \prime} \mathrm{W}$ ) was about 35 kilometers north and 13 kilometers east of Dickinson, North Dakota (Figure 4). There were two separate locations and were several miles apart from each other. These sites were chosen to represent a virgin location of oil drilling (site \#2) and an established oil pad (site \#1) for dust quantification due to vehicle movement. Site 1 was next to a busy road ( $15^{\text {th }}$ St., ND-22 Highway), where several oil pads existed, road was periodically treated with magnesium chloride. In contrast, site 2 was chosen next to a new oil pad drilling area, with a newly constructed gravel road for that oil pad activities only. Additional dust samples were collected from a new location (Figure 4), where sections of road were treated with different dust suppressants (e.g., control, brine, magnesium chloride) and this site had a comparatively high traffic ( $14^{\text {th }}$ St., ND-22 Highway).

The soil in study area mainly consisted of silt loams (more than $20 \%$ sand, silt plus clay content between $70 \%$ and $87 \%$ ). Occasional badlands and buttes are common characteristics of the topography of this area. Prairie grasses are natural in this area and cultivated lands support crops such as alfalfa (Medicago sativa), spring wheat (Triticum aestivum), sunflower (Helianthus аппииs). 


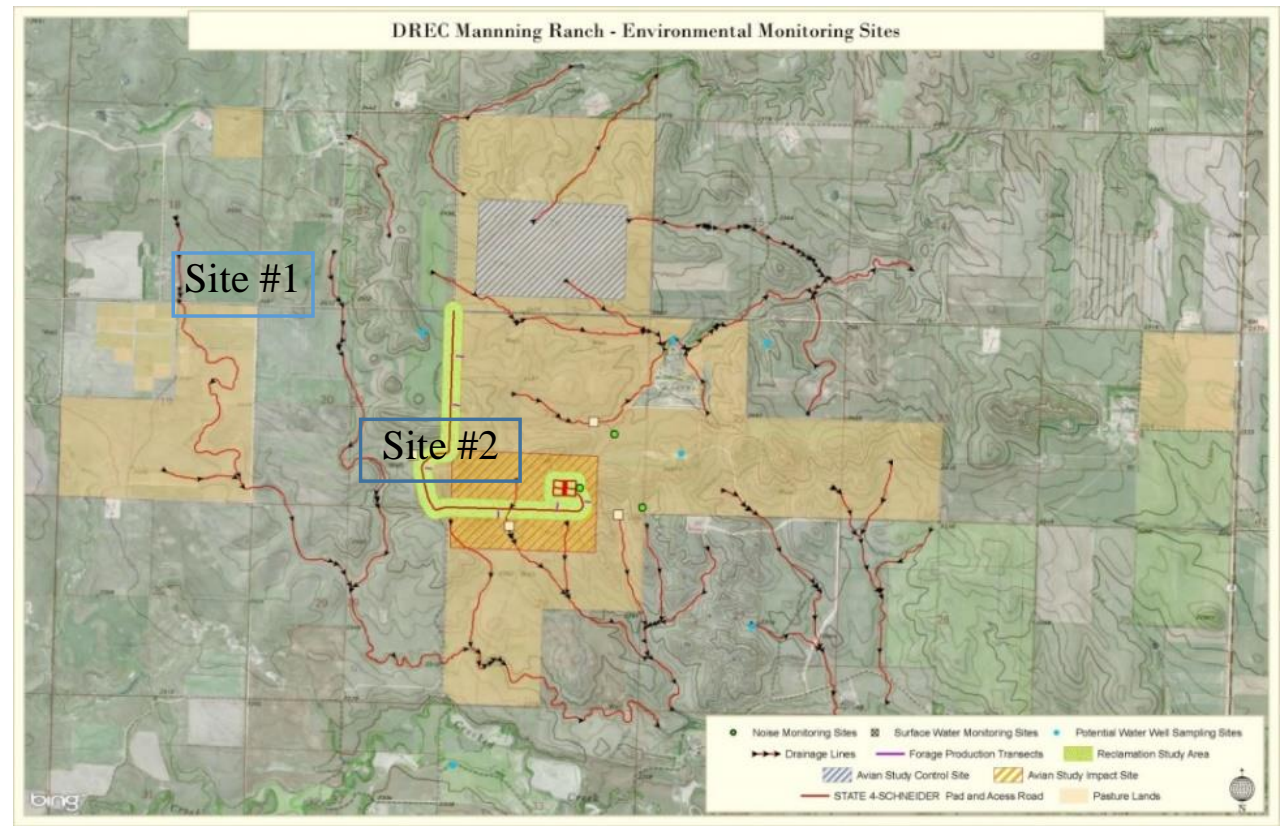

Figure 3. Sampling locations at Manning Ranch (Blue boxes) (Approximately within 5 kilometers west of Manning Ranch)

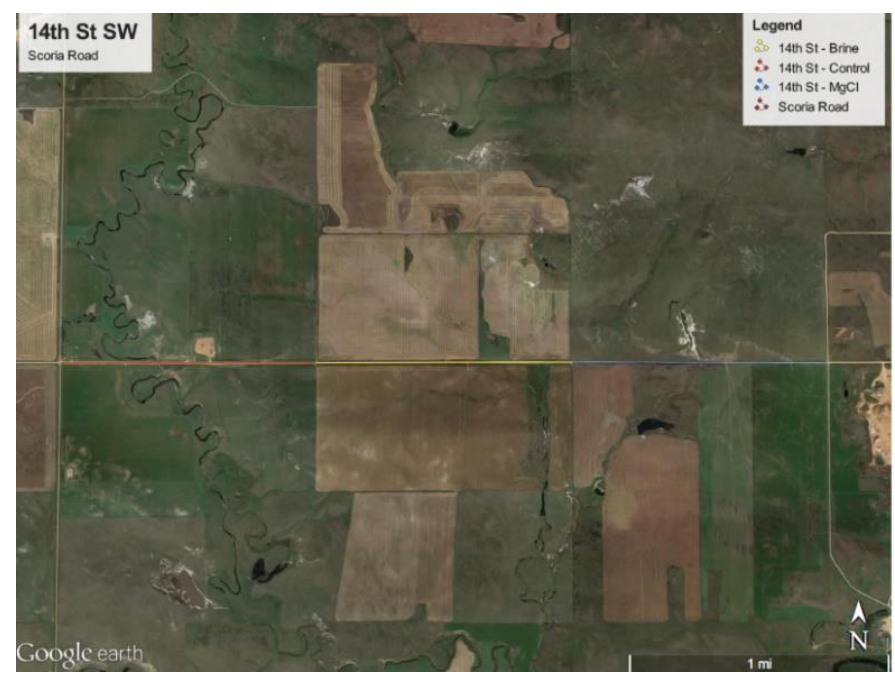

Figure 4. Map of the new sampling location (Red section is control with no additives, yellow section is brine-treated, blue section is magnesium chloride treated) (Approximately 15 kilometers east of Manning Ranch)

The weather profile for the study area is given in the following table (Table 1) (NDAWN, 2015). Average rainfall in this area is $423.8 \mathrm{~mm}$ (averaged over last 6 years) and during the study period the rainfall amount for year 2015 was lower than the normal range $(416.56 \mathrm{~mm})$. During 
sampling period in June, 2015, recorded rainfall was the highest (158.6 mm). Similarly, a strong wind pattern is also observed in the study area and average wind speed varies between 12.2 kmph to $13 \mathrm{kmph}$.

Table 1

Weather Profile near DREC Ranch near Manning, ND - North Dakota Agricultural Weather Network (NDAWN)

\begin{tabular}{ccccccc}
\hline Year & Month & $\begin{array}{c}\text { Average Air } \\
\text { Temperature } \\
\left({ }^{\circ} \mathrm{C}\right)\end{array}$ & $\begin{array}{c}\text { Bare Soil } \\
\text { Temperature } \\
\left({ }^{\circ} \mathrm{C}\right)\end{array}$ & $\begin{array}{c}\text { Average Wind } \\
\text { Speed }(\mathrm{kmph})\end{array}$ & $\begin{array}{c}\text { Maximum } \\
\text { Wind Speed } \\
(\mathrm{kmph})\end{array}$ & $\begin{array}{c}\text { Total } \\
\text { Rainfall } \\
(\mathrm{mm})\end{array}$ \\
\hline 2015 & April & 6 & 7 & 15.1 & 39.6 & 13.0 \\
2015 & May & 11 & 14 & 14.4 & 38.2 & 46.3 \\
2015 & June & 18 & 21 & 10.4 & 37.4 & 158.6 \\
2015 & July & 21 & 23 & 11.5 & 37.0 & 51.6 \\
2015 & August & 11 & 22 & 9.0 & 32.4 & 59.5 \\
\hline
\end{tabular}

\subsection{Particulate matter sampling and calculation of PM concentration}

In this study, soil sample, dust samples and weather data were collected during the study period and their collection procedure have been described below:

\subsubsection{Airmetrics portable air sampler instrument}

Dust samples were collected using EPA approved Airmetrics portable air samplers (Airmetrics, Springfield, OR, USA), which were lightweight, portable and battery operated. The sampler is equipped with particulate matter (PM) and total suspended particulate (TSP) heads. Depending on the type of impactor, $\mathrm{PM}_{2.5}$ or $\mathrm{PM}_{10}$ samples can be collected (Figure 5). Airmetrics portable samplers were chosen due to low cost, portability, and flexibility (programmable capacity) that measure particulate matter: $\mathrm{PM}_{10}$ are particles that have aerodynamic diameter less than or equal to 10 micrometers $(\mu \mathrm{m}) ; \mathrm{PM}_{2.5}$ are particles that have 
aerodynamic diameter less than 2.5 micrometers $(\mu \mathrm{m})$ and Total Suspended Particulates (TSP) are particles that have an aerodynamic diameter up to 45 micrometers $(\mu \mathrm{m})$.
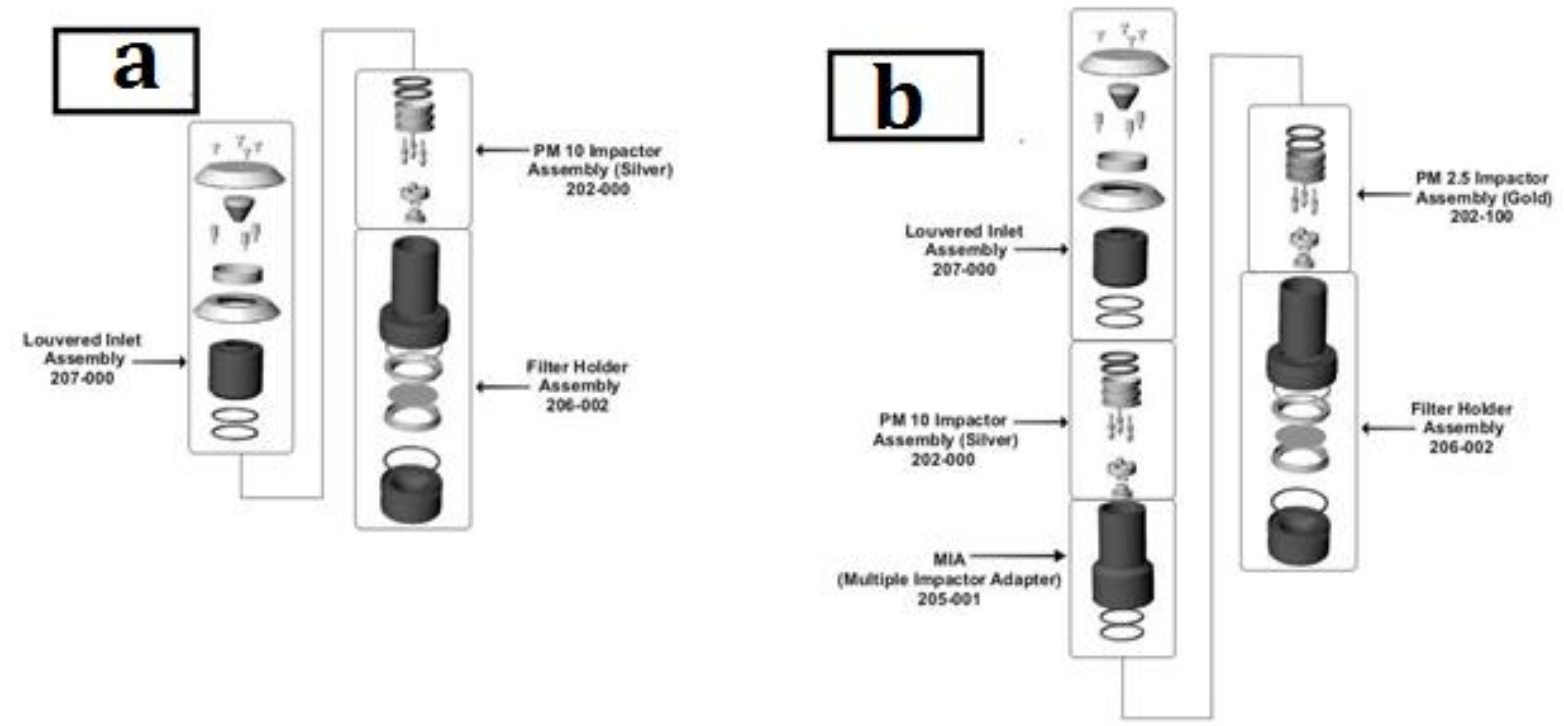

Figure 5. Schematic diagram and combination of impactor of the TAS (; a. exterior of sampler, b. interior of sampler, a. PM10 impactor assembly, b. PM2.5 impactor assembly (Airmetrics, Springfield, OR, USA) Photos taken from Airmetrics MiniVol ${ }^{\mathrm{TM}}$ TAS Manual www.airmetrics.com)

Before deploying samplers, they were checked in the lab for any leakage by performing a single point flow check, and compared with the calibration curve that was established during the original calibration. The typical set air flow rate for the sampler is $0.005 \pm(0.05 \times 0.005)$ cubic meter per minute under ambient conditions. However, based on the ambient temperature and barometric pressure, actual rotameter set point was adjusted to operate at $0.005 \mathrm{~m}^{3} / \mathrm{min}(5$ liter/min) at actual condition. The sampler flow rate was set according to flow rate calculated as $\mathrm{Q}_{\text {ind }}=1_{\mathrm{sp}}$. This is given by the equation 1 .

$$
Q_{\text {ind }}=l_{\mathrm{sp}}=\frac{5 \times \sqrt{\left[\frac{\mathrm{P}_{\mathrm{std}}}{\mathrm{P}_{\mathrm{act}}} \times \frac{\mathrm{T}_{\mathrm{act}}}{\mathrm{T}_{\mathrm{std}}}\right]}-\mathrm{b}_{\mathrm{vol}}}{\mathrm{m}_{\mathrm{vol}}}
$$

Where: 
$\mathrm{m}_{\mathrm{vol}}, \mathrm{b}_{\mathrm{vol}}=$ the sampler's calibration slope and intercept

$\mathrm{Q}_{\text {ind }}=$ Flow Rate $($ liters $/ \mathrm{min})=1_{\mathrm{sp}}$

$\mathrm{P}_{\text {std }}=$ standard atmospheric pressure, $760 \mathrm{mmHg}$

$\mathrm{P}_{\text {act }}=$ actual ambient pressure, $\mathrm{mmHg}$

$\mathrm{T}_{\text {std }}=$ standard temperature, $298 \mathrm{~K}$

$\mathrm{T}_{\mathrm{act}}=$ actual ambient temperature, $\mathrm{K}$

For each sampler, separate $Q_{\text {ind }}$ was calculated and set point flow rate was adjusted to achieve an actual flow rate of $0.005 \mathrm{~m}^{3} / \mathrm{min} \pm(0.05 \times 0.005) \mathrm{m}^{3} / \mathrm{min}$.

The sampler was mounted to a pole vertically as shown in Figure 6. After several samplings, the impactor was cleaned and greased for the next sampling.

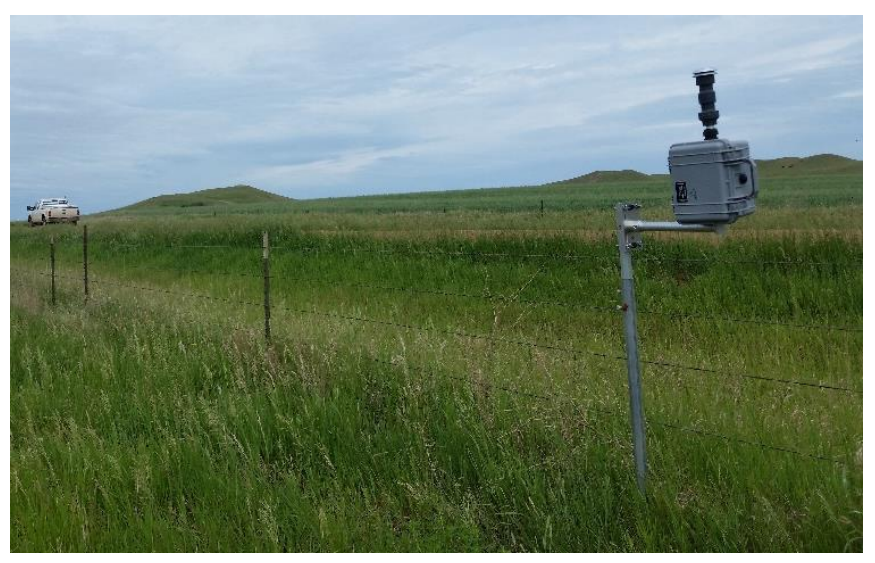

Figure 6. MiniVol ${ }^{\mathrm{TM}}$ Portable Air Sampler in operation at site \#1 (vertically mounted)

\subsubsection{Filter preparation and conditioning, and setup}

High purity fiber circular Whatman ${ }^{\mathrm{TM}}$ Millipore ${ }^{\circledR} 47 \mathrm{~mm}$ quartz $\left(\mathrm{SiO}_{2}\right)($ pore size $=2.2$ $\mu \mathrm{m})$ (Figure 7b) (GE Healthcare Bio-sciences, Pittsburgh, PA, USA) filters were used in this study for dust sampling. These quartz filters were used because they have high filtration rate, good trace level analysis, are heat resistant and useful for measuring diesel emissions. Before using them for dust sampling, filters were labelled with ultra-fine Sharpie ${ }^{\circledR}$ pen while wearing 
latex gloves and kept into petri-dishes (48 $\mathrm{mm}$ in diameter) and conditioned in an environmentally controlled room (relative humidity $=50.5 \pm 0.2 \%$, temperature $=22.6 \pm 1.4{ }^{\circ} \mathrm{C}$ ) at the Nanoscale Science and Engineering (CNSE) Research lab at NDSU. Conditioning was done for eliminating organic species and presence of semi-volatile materials. Pre- and postsampling weight of filters were measured with a Sartorius CP2P microbalance (Sartorius Corporation, NY, USA) in an environmentally controlled room to determine particulate matter mass with a resolution of $1 \mu \mathrm{g}(0.001 \mathrm{mg})$ (Figure $7 \mathrm{a})$. To avoid static, a polonium bar at the back of the microbalance was used. During conditioning, filters were reweighted 2-3 times for consistent weight. The differences in weight after each measurement should not exceed $0.5 \%$ of the previous weight. After conditioning, filters were used within 7 days and protective holders were used during transportation. On the field, a cassette separator was used for insertion and removal of these filters to and from the cassette. After inserting the filter, pre-calculated actual flow rate was adjusted for the sampler and sampling was started.

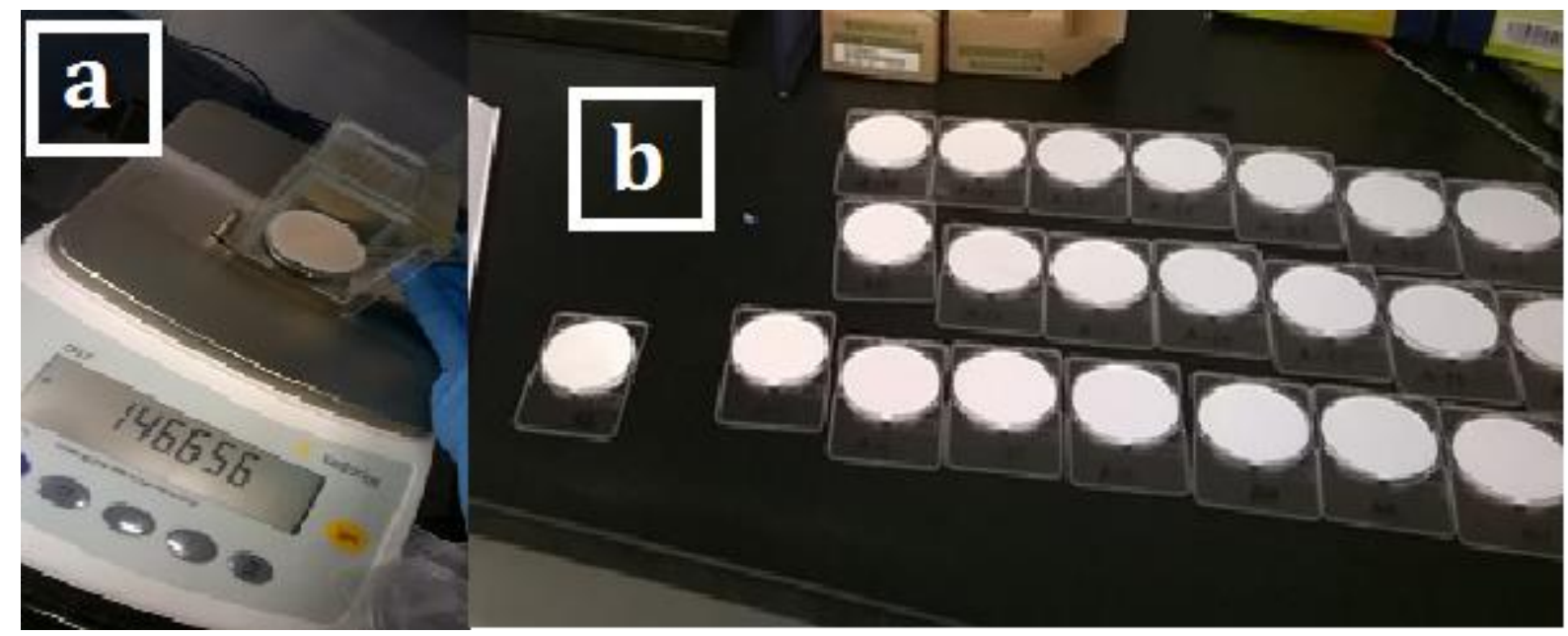

Figure 7. a. Sartorius CP2P Microbalance at CNSE Lab, NDSU; b. Millipore Quartz Filters while being conditioned. 


\subsubsection{Sampling setup}

At each site, four air samplers were used and their deployment has been illustrated in Figure 8. For site \#1 (Figure 8a), three samplers were set on the south side (downwind) (Ljepoja, 2015) of the road and one sampler was set on the north side. The north side of the road had PM 10 only, whereas south side had two $\mathrm{PM}_{10}$ and one $\mathrm{PM}_{2.5}$ configured samplers. The weather station was installed about $60 \mathrm{~m}$ away from the road on the south side. In site \#2 (Figure 8b), same configuration was applied, but no weather station was installed, since both stations were only 5 kilometers apart. In the case of the additional new site (Figure 8c), TSP configured samplers were deployed on the both north and south side of the untreated section. For the brine treated section, the north side of the road had one TSP sampler and south side of the road had one TSP, one $\mathrm{PM}_{10}$ and one $\mathrm{PM}_{2.5}$ sampler. However, for magnesium chloride treated section of the road, only TSP samplers were deployed on both sides.

Besides the dust sample, composite soil samples (mixture of three samples) were collected at site 2 at different distances $(12 \mathrm{~m}, 30 \mathrm{~m}, 60 \mathrm{~m}, 90 \mathrm{~m}$ from the center of the road on both south and north side) using a $25.4 \mathrm{~mm}$ soil core sampler (inside the cutting tip, diameter $=$ $19 \mathrm{~mm}$ ). Each soil core was taken at a $150 \mathrm{~mm}$ depth. Before collecting the soil sample in sampler bags, vegetation and ground litter were removed to avoid contamination by plant materials. Then, the cores were stored in ziploc bags and labelled with a unique ID. The sampling was done on a monthly basis to see the impact of dust on soil quality. 

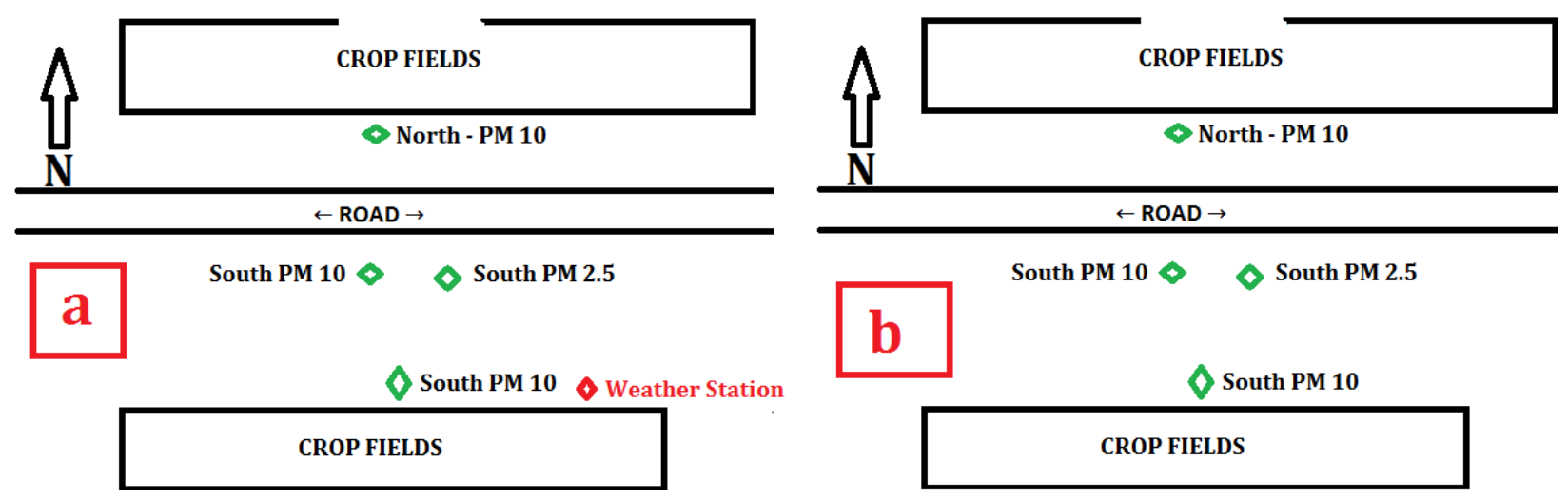

South PM $10 \diamond \quad \diamond$ South PM 2.5

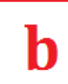

South PM 10

CROP FIELDS

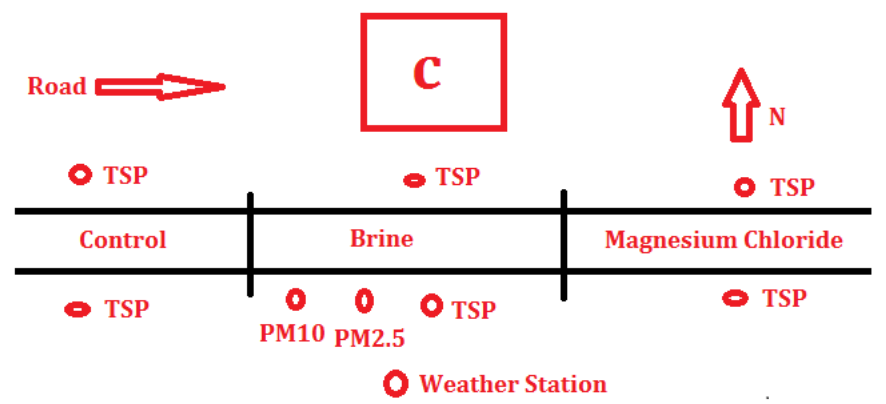

Figure 8. Experimental Setup of different locations: a. experimental setup at site \#1; b. experimental design at site \#2; c. experimental design at site 3

\subsubsection{Meteorological data}

In-situ meteorological data (e.g., temperature, relative humidity, pressure, wind speed, gust speed, and wind direction) were collected at site 1 using Hobo micro weather station data logger (H21-002) (Onset, Bourne, MA, USA) (Figure 9). Additionally, weather data was also downloaded from North Dakota Agricultural Weather Network (NDAWN) and National Weather Service (NWS) to correlate important factors with the dust emissions. 


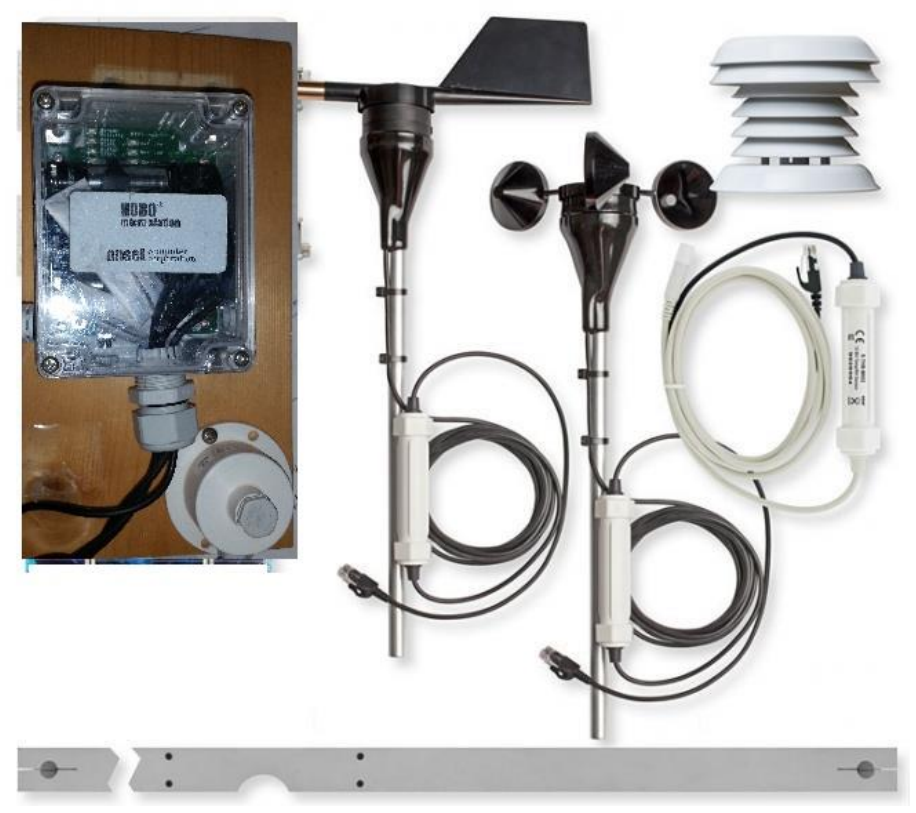

Figure 9. Onset Hobo Data Logger (H21-002) (Partially taken from Onset Website www.onsetcomp.com)

\subsubsection{Vehicle tracking}

Two battery-operated Simmons Whitetail Cameras (119234C) (Simmons Outdoor Products, Overland Park, KS, USA) were used for tracking the number of vehicles passing through the study site (Figure 10). Camera was equipped with motion sensor and night vision (Infra-red) capabilities for capturing photos even during night time of a passing vehicle. These cameras were set up on the same pole as the air sampler in such a way that it would pick up both fast and slow moving objects efficiently. After each sampling, number of vehicles passed during the sampling period was counted and correlated with total dust emission during the sampling. 


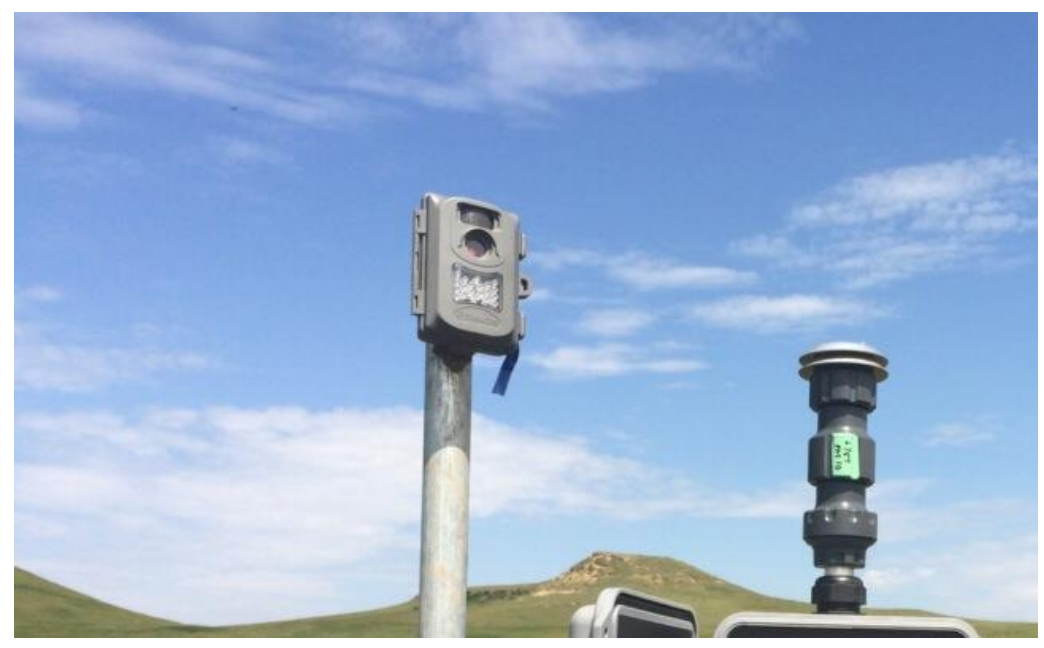

Figure 10. Simmons Camera (deployed in site \#2)

\subsubsection{Calculation}

PM concentration of air sample taken with the MiniVol sampler was calculated as follows:

$$
\mathrm{PM}_{\mathrm{act}}=\frac{\mathrm{M}_{\mathrm{PM}}}{\mathrm{V}_{\mathrm{act}}}
$$

Where:

$\mathrm{PM}_{\text {act }}=$ actual $\mathrm{PM}$ concentration, $\mu \mathrm{g} / \mathrm{m}^{3}$ (actual condition)

$\mathrm{M}_{\mathrm{PM}}=\mathrm{PM}$ concentration, $\mu \mathrm{g} / \mathrm{m}^{3}$ (Standard condition)

$\mathrm{V}_{\mathrm{act}}=$ Volume of air, $\mathrm{m}^{3}$ (actual condition)

The volume of actual air passed through the filter during sampling period at actual ambient condition would be calculated as:

$$
\mathrm{V}_{\mathrm{act}}=\frac{60_{\mathrm{min} / \mathrm{hr}} \times \mathrm{Q}_{\mathrm{act}} \times \mathrm{t}_{\mathrm{hr}}}{1000_{1 / \mathrm{m}^{3}}}
$$

Where:

$\mathrm{Q}_{\mathrm{act}}=$ Flow rate of the sampler, liters/min; 
$\mathrm{t}_{\mathrm{hr}}=$ Sampling period, $\mathrm{hr}$

The flow rate through the sampler is:

$$
\mathrm{Q}_{\mathrm{act}}=\left(\mathrm{m}_{\mathrm{vol}} \times \mathrm{Q}_{\mathrm{ind}}+\mathrm{b}_{\mathrm{vol}}\right) \times \sqrt{\left[\frac{\mathrm{P}_{\mathrm{std}}}{\mathrm{P}_{\mathrm{act}}} \times \frac{\mathrm{T}_{\mathrm{act}}}{\mathrm{T}_{\text {std }}}\right]}
$$

Where:

$\mathrm{m}_{\mathrm{vol}}, \mathrm{b}_{\mathrm{vol}}=$ the sampler's calibration slope and intercept

$\mathrm{Q}_{\text {ind }}=$ Flow Rate (liters $\left./ \mathrm{min}\right)$

$\mathrm{P}_{\text {std }}=$ standard atmospheric pressure, $760 \mathrm{mmHg}$

$\mathrm{P}_{\mathrm{act}}=$ actual ambient pressure, $\mathrm{mmHg}$

$\mathrm{T}_{\text {std }}=$ standard temperature, $298 \mathrm{~K}$

$\mathrm{T}_{\text {act }}=$ actual ambient temperature, $\mathrm{K}$

\subsection{Sample analysis}

After the quantification of dust amount, random filters were taken for Scanning Electron Microscope (SEM) analysis. At the same time, dust morphology and mineral identification were done by the Energy Dispersive X-Ray Spectroscopy (EDS) analysis. Both SEM and EDS analysis were done in Electron Microscopy Center, NDSU on a JEOL JSM-6490LV SEM (JEOL USA, Inc, MA, USA). For SEM analysis, four small rectangular sections were taken from each filter with a razor blade and attached to cylindrical aluminum mounts with a double-stick carbon adhesive tape (Ted Pella, Redding, CA, USA) (Figure 11). In this analysis, samples were not coated with carbon or gold because of the possibility of having biogenic organisms in the filters, because biogenic organisms are basically made of carbon and oxygen $(\mathrm{C}+\mathrm{O}>75 \%$ of the total molecular weight), which may bias the quantification. During EDS analysis, when the carbon was $<10 \%$, the carbon was excluded from ‘quant spectrum' option. About 10-20 images were 
taken per sub-sample and when necessary, EDS was done on the image by picking up several points. The magnification level used for taking the images was $\mathrm{x} 1500$.

The magnification level and spot size was fixed according to particles countered in the filters. Energy-dispersive X-ray information was also collected using a Nanotrace EDS detector with a NORVAR light-element window and Noran System Six imaging system (ThermoFisher Scientific, Madison WI, USA) at an accelerating voltage of $15 \mathrm{keV}$ for the JSM-6490LV.

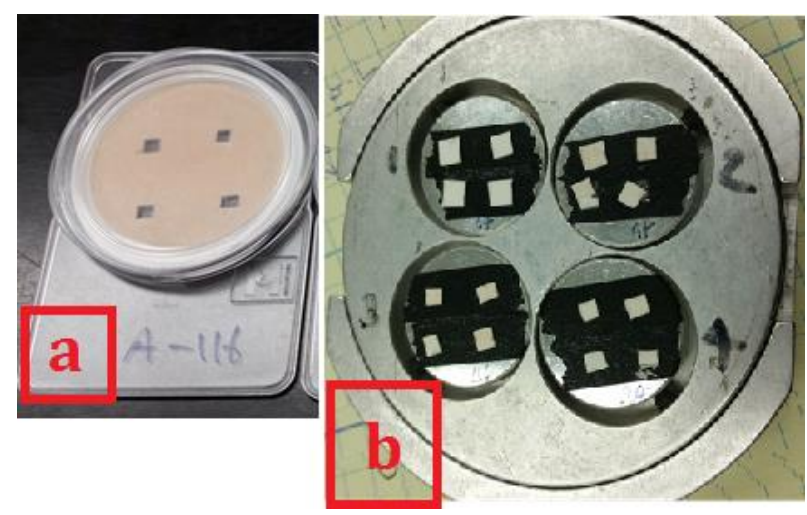

Figure 11. Sample Preparation for SEM analysis: a. small sections cut from filter; b. sections placed on carbon tape on cylindrical mounts

\subsubsection{Identification of mineral phase from SEM results}

Relative atomic weight percentages were taken from SEM results to calculate approximate empirical formulas. In ideal case, each coefficient for a crystallographic site will be a whole number, and will give accurate mineral formula. SEM/EDS outputs data as percentage weight of atoms or oxides present in the sample. These data together with the atomic mass of corresponding elements are used to calculate empirical formula of the mineral. The procedure is simple for pure phases and complex with phases with impurities and trace elements. Figure 12 shows a sample SEM image and EDS spectrum for quartz mineral, and the calculation procedure for identifying the mineral. 


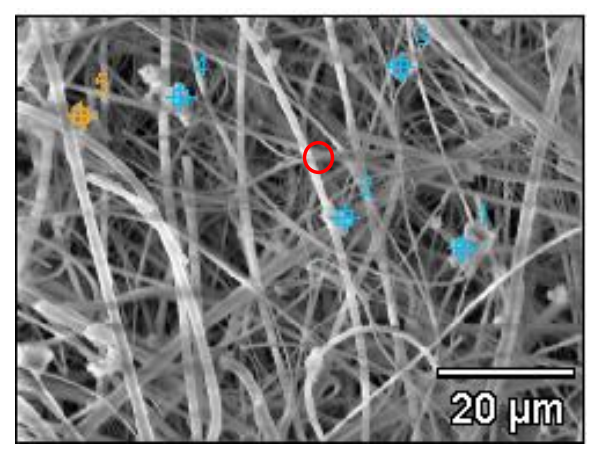

Full scale counts: 4673

158426-A9(8)_pt3

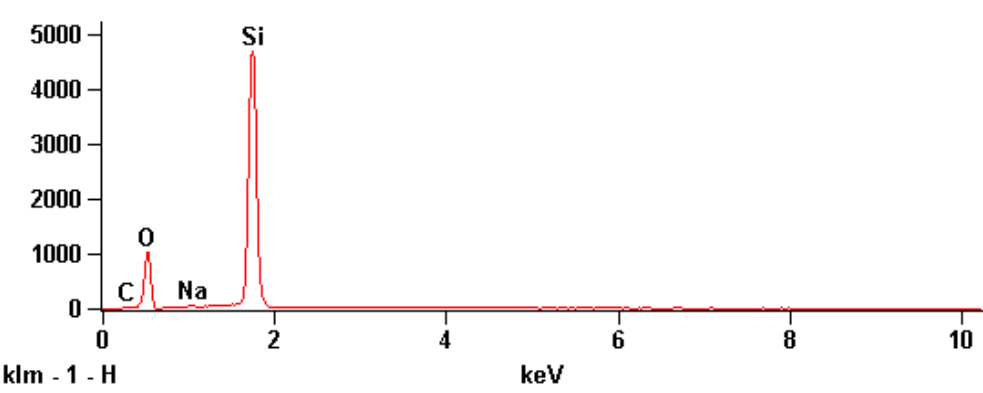

\begin{tabular}{|l|l|l|l|l|}
\hline Elements & $\mathrm{O}$ & $\mathrm{Si}$ & $\mathrm{Na}$ & Notes \\
\hline wt. \% & 53.06 & 46.40 & 0.54 & Mineral: Quartz $\left(\mathrm{SiO}_{2}\right) ;$ \\
\cline { 1 - 4 } grams/mol & 16.0 & 28.09 & 22.98 & Major elements: O, Si; Trace elements: Na; \\
\cline { 1 - 4 } mols & 3.32 & 1.65 & 0.02 & Nearly Spherical particles; \\
\cline { 1 - 3 } Normalized mols & 2 & 1 & Negligible & \\
\cline { 1 - 2 } & & & & \\
\hline
\end{tabular}

Figure 12. Calculation of possible mineral/phase group from SEM data (Quartz)

Reported weight percentages were divided by atomic mass to obtain number of moles normalized. this particular sample had the ratio of $1 \mathrm{~mol} \mathrm{Si}$ and $2 \mathrm{~mol} \mathrm{O}$ (and a trace amount of $\mathrm{Na})$. So, it was determined to be quartz.

The procedure is similar for a complex mineral oxide weight as shown in Figure 13. In this case, molar mass of oxide is used instead of the atomic mass. In this case, the calculation is complex. If the number of moles could not be brought to a whole number, an approximate empirical formula is calculated. Morphology and knowledge in mineralogy and crystallography can be beneficial in this case for identification. Figure 13 shows the calculation for an aluminosilicate mineral phase. The mole numbers can't be brought to whole numbers which could be due to the electron beam accuracy of SEM machine and fluorescence from silica filters. 


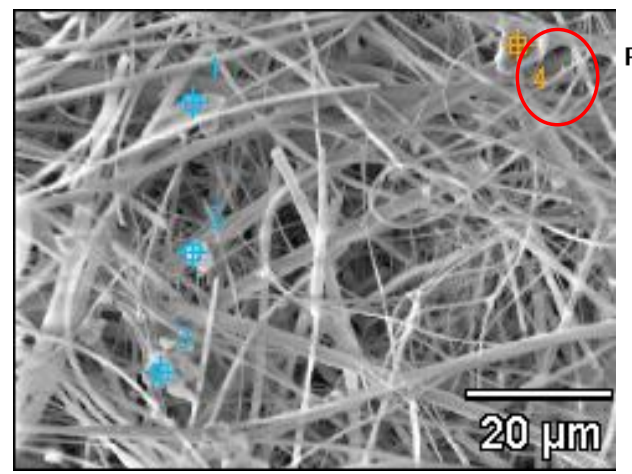

Full scale counts: $3723 \quad$ 158426-A9(1)_pt4

\begin{tabular}{|c|c|c|c|c|c|c|c|c|c|c|}
\hline Elements & $\mathrm{O}$ & $\mathrm{Na}$ & $\mathrm{Mg}$ & $\mathrm{Al}$ & $\mathrm{Si}$ & $\mathrm{S}$ & $\mathrm{K}$ & $\mathrm{Ca}$ & $\mathrm{Fe}$ & Notes \\
\hline wt. $\%$ & 47.58 & 1.18 & 0.61 & 15.63 & 26.55 & 0.70 & 3.01 & 1.42 & 3.31 & Possible Mineral \\
\hline grams/mol & 16.0 & 22.98 & 24.3 & 26.98 & 28.09 & 32.06 & 39.09 & 40.07 & 55.86 & Phase: \\
\hline mols & 2.97 & 0.05 & 0.025 & 0.58 & 0.94 & 0.02 & 0.078 & 0.035 & 0.059 & Aluminosilicates \\
\hline $\begin{array}{l}\text { Normalized } \\
\text { mols }\end{array}$ & 136 & 2 & 1 & 27 & 43 & 1 & 4 & 2 & 3 & $\begin{array}{l}\text { Major elements: } \\
\mathrm{O}, \mathrm{Si}, \mathrm{Al} \text {; Trace } \\
\text { elements: } \mathrm{Na} \text {, } \\
\mathrm{Mg}, \mathrm{S}, \mathrm{K}, \mathrm{Ca}, \\
\mathrm{Fe} \text {; } \\
\text { Nearly Spherical } \\
\text { particles; } \\
\text { Formula: } 136 \mathrm{O} \text {, } \\
2 \mathrm{Na}, 1 \mathrm{Mg}, 27 \\
\mathrm{Al}, 43 \mathrm{Si}, 1 \mathrm{~S}, 4 \\
\mathrm{~K}, 2 \mathrm{Ca}, 3 \mathrm{Fe}\end{array}$ \\
\hline
\end{tabular}

Figure 13. Calculating possible complex mineral formulas from SEM data (Aluminosilicates)

\subsection{Soil analysis}

After collecting the soil cores from site 2, soil samples were air dried for at least 72 hours before processing and unique ID was given to each sample. The soil was hand crushed to pass through a $2 \mathrm{~mm}$ sieve and plants residues and rock fragments were removed. Then, a $10 \mathrm{~g}$ subsample of soil was taken from the bulk samples for ball-milling. The soil subsamples were milled to pass through a No. $80(80$-mesh opening=180 $\mu \mathrm{m})$. Then, the prepared samples were analyzed using Inductively coupled plasma mass spectrometry (ICP-MS) at Activation Laboratories Ltd (Ancaster, ON, Canada) using the Ultratrace 2 method (aqua regia digest). 


\subsection{Statistical analysis}

Statistical analysis was done using SAS 9.4 software to predict particulate matter concentration by PROC STEPWISE statement with Forward Selection Method (FSM). PROC CORR was also used to determine the correlation between independent and dependent variables. The independent variables were temperature, pressure, vehicle count, rainfall, wind speed, and wind direction. This PROC STEPWISE statement chooses the best model and provides an equation with maximized $r^{2}$ value. 


\section{RESULTS AND DISCUSSION}

\subsection{Particulate matter concentrations}

Particulate matter (PM) is one of the Ambient Air Quality Standards (AAQSs) pollutants and constitute a major class of air pollution (Cooper \& Alley, 2002). Figure 14 shows the average $\mathrm{PM}$ concentrations $\left(\mathrm{PM}_{10}\right.$ and $\left.\mathrm{PM}_{2.5}\right)$ measured at site 1 over two years with respect to the number of vehicles and the amount of rainfall during the corresponding sampling dates, while, figure 15 shows an example of PM concentrations exceeding NAAQS values on June 2830, 2016 with respect to the sampling locations (i.e., north or south side, corresponding distances from the center of the roads). Figure 16 shows the yearly average PM concentrations ( $\mathrm{PM}_{10}$ and $\mathrm{PM}_{2.5}$ ). Table 2 shows the stepwise regression analysis of PM at site 1.

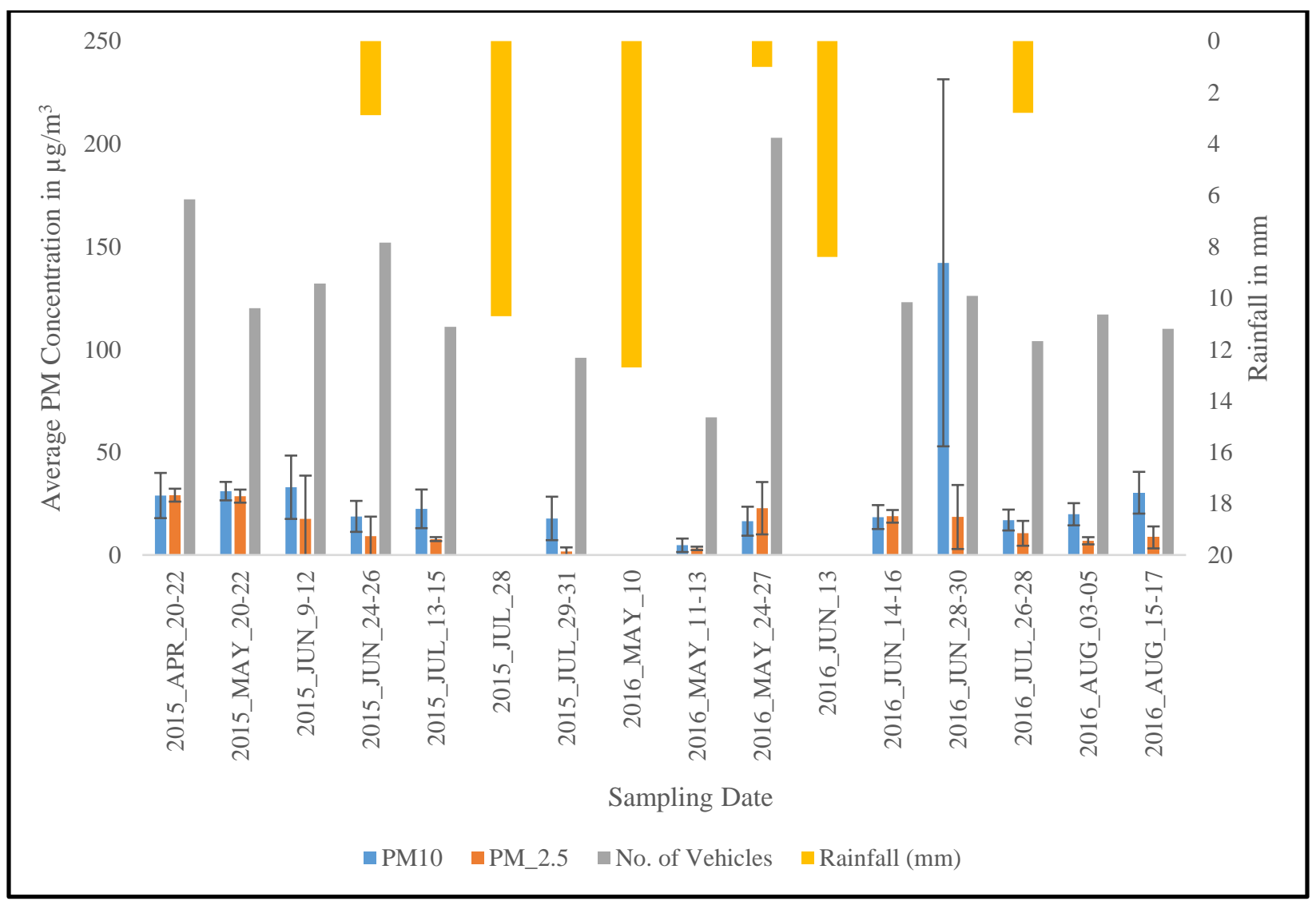

Figure 14. Average PM concentrations with respect to traffic and rainfall at site 1. 


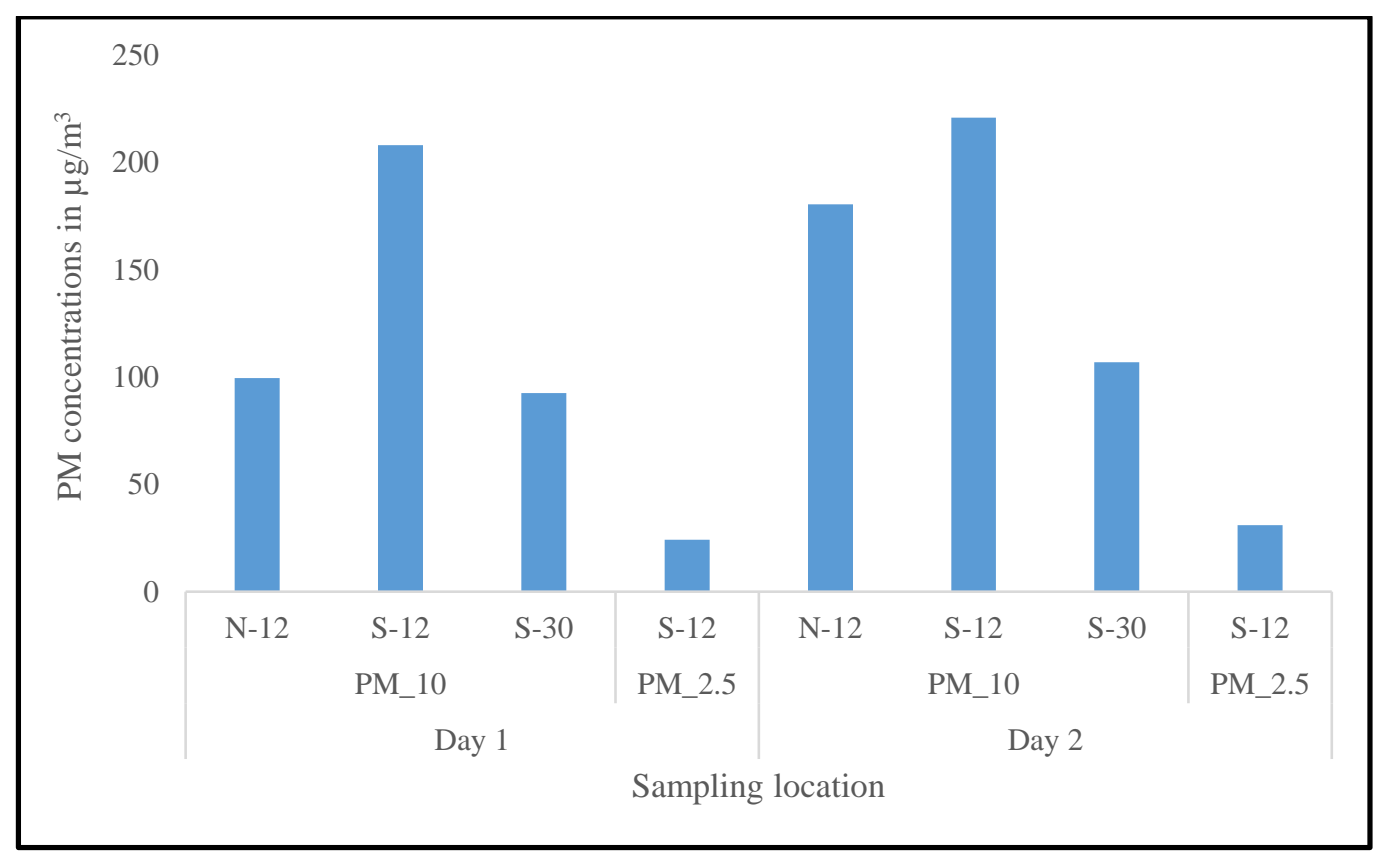

Figure 15. Average PM concentrations on June 28-30, 2016 exceeding NAAQS value with respect to sampling locations at site $1(\mathrm{~N}-12$ refers to north side sampler at $12 \mathrm{~m}$ distance from the center of the road).

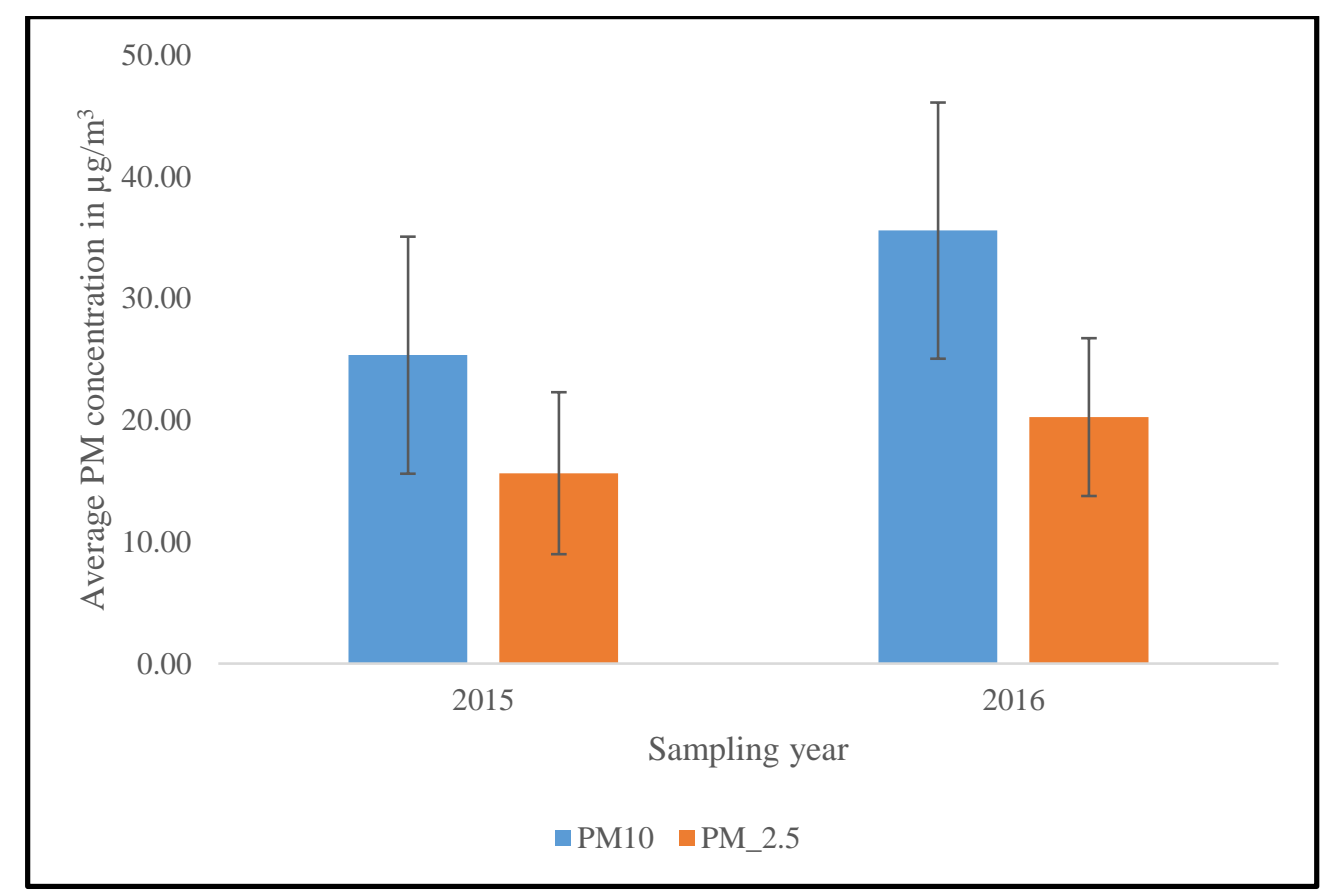

Figure 16. Yearly average PM concentrations at site 1. 
Table 2

Stepwise regression analysis results of PM concentrations at site 1

\begin{tabular}{|c|c|c|}
\hline $\begin{array}{l}\text { Particulate } \\
\text { matter type }\end{array}$ & $\begin{array}{l}\text { Year of } \\
\text { sampling }\end{array}$ & Stepwise regression model equations \\
\hline \multirow{3}{*}{$\mathrm{PM}_{10}$} & $\begin{array}{c}2015 \& 2016 \\
\text { combined }\end{array}$ & No variables were statistically significant \\
\hline & 2015 & $\begin{array}{c}\mathrm{PM}_{10}=28.516-79.55 \times \text { rainfall_in_mm } \\
\left(r^{2}=0.07\right)\end{array}$ \\
\hline & 2016 & $\begin{array}{c}\mathrm{PM}_{10}=46.978+1.4615 \times \text { vehicle_count }-32.2796 \times \\
\text { wind_speed }-0.37429 \times \text { wind_direction }-51.06820 \times \\
\text { rainfall_in_mm } \\
\left(r^{2}=0.30\right)\end{array}$ \\
\hline \multirow{3}{*}{$\mathrm{PM}_{2.5}$} & $\begin{array}{c}2015 \& 2016 \\
\text { combined }\end{array}$ & $\begin{array}{c}\mathrm{PM}_{2.5}=-0.75421+0.19184 \times \text { vehicle_count } \\
\left(r^{2}=0.16\right)\end{array}$ \\
\hline & 2015 & $\begin{array}{c}\mathrm{PM}_{2.5}=0.98252+0.02480 \times \text { wind_direction }+63.485 \times \\
\text { rainfall_in_mm } \\
\left(r^{2}=0.51\right)\end{array}$ \\
\hline & 2016 & $\begin{array}{c}\mathrm{PM}_{2.5}=-11.33165+0.43686 \times \text { vehicle_count } \\
\left(r^{2}=0.38\right)\end{array}$ \\
\hline
\end{tabular}

Notes: All variables here are significant at 0.15 level $(\mathrm{p}=0.15), \mathrm{r}^{2}$ values reported are model $\mathrm{r}^{2}$ values.

However, based on 24-hour sampling period, the $\mathrm{PM}_{10}$ concentration value ranged from $7.55 \mu \mathrm{g} / \mathrm{m}^{3}$ to $60.5 \mu \mathrm{g} / \mathrm{m}^{3}$ in 2015 and from $0.79 \mu \mathrm{g} / \mathrm{m}^{3}$ to $261.45 \mu \mathrm{g} / \mathrm{m}^{3}$ in 2016 . Similarly, the $\mathrm{PM}_{2.5}$ concentration value ranged from $0.34 \mu \mathrm{g} / \mathrm{m}^{3}$ to $15.85 \mu \mathrm{g} / \mathrm{m}^{3}$ in 2015 and from $2.63 \mu \mathrm{g} / \mathrm{m}^{3}$ to $37.00 \mu \mathrm{g} / \mathrm{m}^{3}$ in 2016. Figure 16 shows the average $\mathrm{PM}_{10}$ concentrations in 2015 and 2016 were $25.33 \pm 9.74 \mu \mathrm{g} / \mathrm{m}^{3}$ and $35.56 \pm 20.25 \mu \mathrm{g} / \mathrm{m}^{3}$, respectively; and the average $\mathrm{PM}_{2.5}$ concentrations in 2015 and 2016 were $15.64 \pm 6.65 \mu \mathrm{g} / \mathrm{m}^{3}$ and $20.25 \pm 6.48 \mu \mathrm{g} / \mathrm{m}^{3}$, respectively. Most of the time, the $\mathrm{PM}_{10}$ concentration was below the NAAQS value $\left(150 \mu \mathrm{g} / \mathrm{m}^{3}\right)$. However, during June 28-30, 2016 sampling (figure 15), the average $\mathrm{PM}_{10}$ concentration was $142.14 \pm$ $89.28 \mu \mathrm{g} / \mathrm{m}^{3}$ which exceeded the NAAQS threshold values. This may be attributed to the gravel road construction and ongoing well pad construction near site $1\left(15^{\text {th }} \mathrm{St}\right)$. The average PM 
concentrations for 2016 were slightly higher than that of 2015 which might be due to drier weather and road construction/leveling activities. In site $1, \mathrm{PM}_{2.5}$ concentration value exceeded $\left(37 \mu \mathrm{g} / \mathrm{m}^{3}\right)$ NAAQS reference value for $\mathrm{PM}_{2.5}\left(35 \mu \mathrm{g} / \mathrm{m}^{3}\right.$ for 24 -hour sampling period) for one instance (June 28-30, 2016) during the sampling time. Except for one or two incidents, the PM concentrations were below the NAAQS reference value despite of having high traffic.

PM emissions from a road likely depends on road conditions (dry vs. wet, treated vs. untreated), the number of vehicles, and weather conditions (precipitation, calm vs. windy), etc. The lower PM concentration in site \#1 during June 24-26, 2015 was likely due to road treatment. The road $\left(15^{\text {th }} \mathrm{St}\right)$ adjacent to site 1 was periodically treated with dust suppressants i.e., magnesium chloride. Besides, there was $2.88 \mathrm{~mm}$ of rainfall during that sampling period, which might also contribute to lower PM emissions. There was a significant drop in PM emissions during May 1113, 2016, which may be attributed to freezing and thawing effect as well as lower traffic activities.

A stepwise regression analysis was conducted to find out the impact of different variables on PM emission. Statistical analysis revealed that, in 2015 sampling, the rainfall was poorly correlated $\left(\mathrm{r}^{2}=0.07\right)$ with $\mathrm{PM}_{10}$ concentrations; but, the combination of rainfall and wind direction had a better relationship $\left(\mathrm{r}^{2}=0.51\right)$ in case of $\mathrm{PM}_{2.5}$ concentration emission at a significance level of $\mathrm{p}=0.15$. In $2016, \mathrm{PM}_{10}$ concentrations were moderately correlated $\left(\mathrm{r}^{2}=\right.$ 0.30) with vehicle passing by, wind speed, wind direction, and rainfall. A similar or equally better correlation $\left(\mathrm{r}^{2}=0.39\right)$ was observed for the $\mathrm{PM}_{2.5}$ concentrations.

Figure 17 shows the average $\mathrm{PM}$ concentrations $\left(\mathrm{PM}_{10}\right.$ and $\left.\mathrm{PM}_{2.5}\right)$ measured at site 2 with respect to the number of vehicles and the amount of rainfall during the corresponding sampling dates. Figure 18 shows an example sampling date (May 20-22, 2015) when the measured PM 
concentration exceeded the NAAQS values at site 2 and figure 19 shows the yearly average PM concentration at site 2 . Table 3 shows the stepwise regression analysis of PM at site 2 .

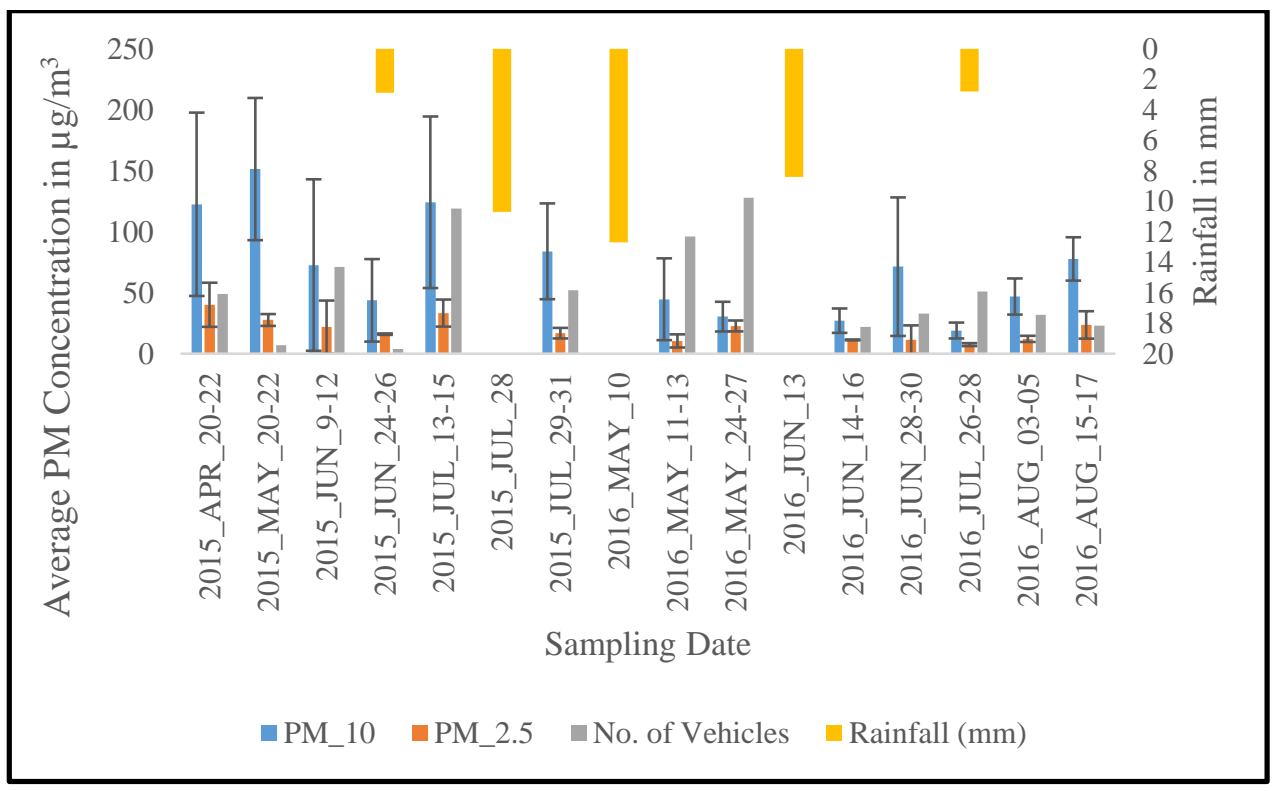

Figure 17. Average PM concentrations with respect to traffic and rainfall at site 2.

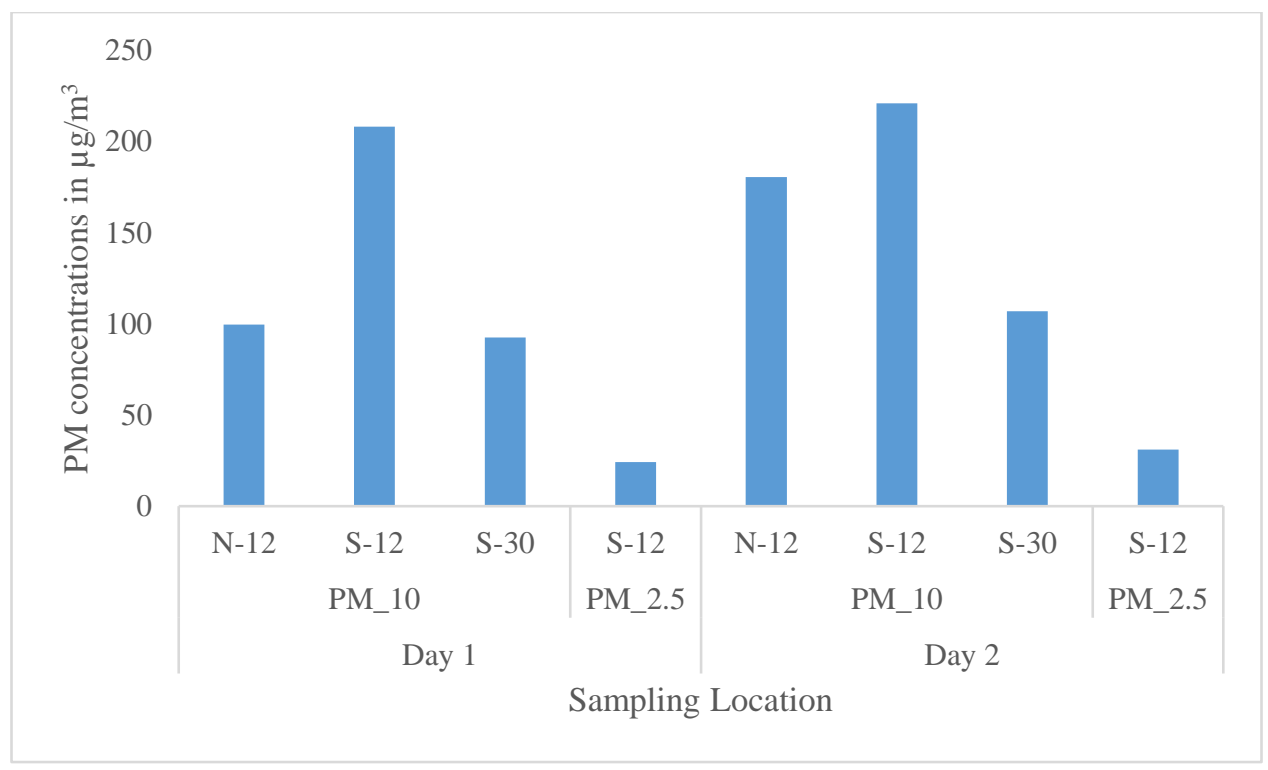

Figure 18. Average PM concentrations on May 20-22, 2015 exceeding NAAQS value with respect to sampling locations at site $2(\mathrm{~N}-12$ refers to north side sampler at $12 \mathrm{~m}$ distance from the center of the road). 


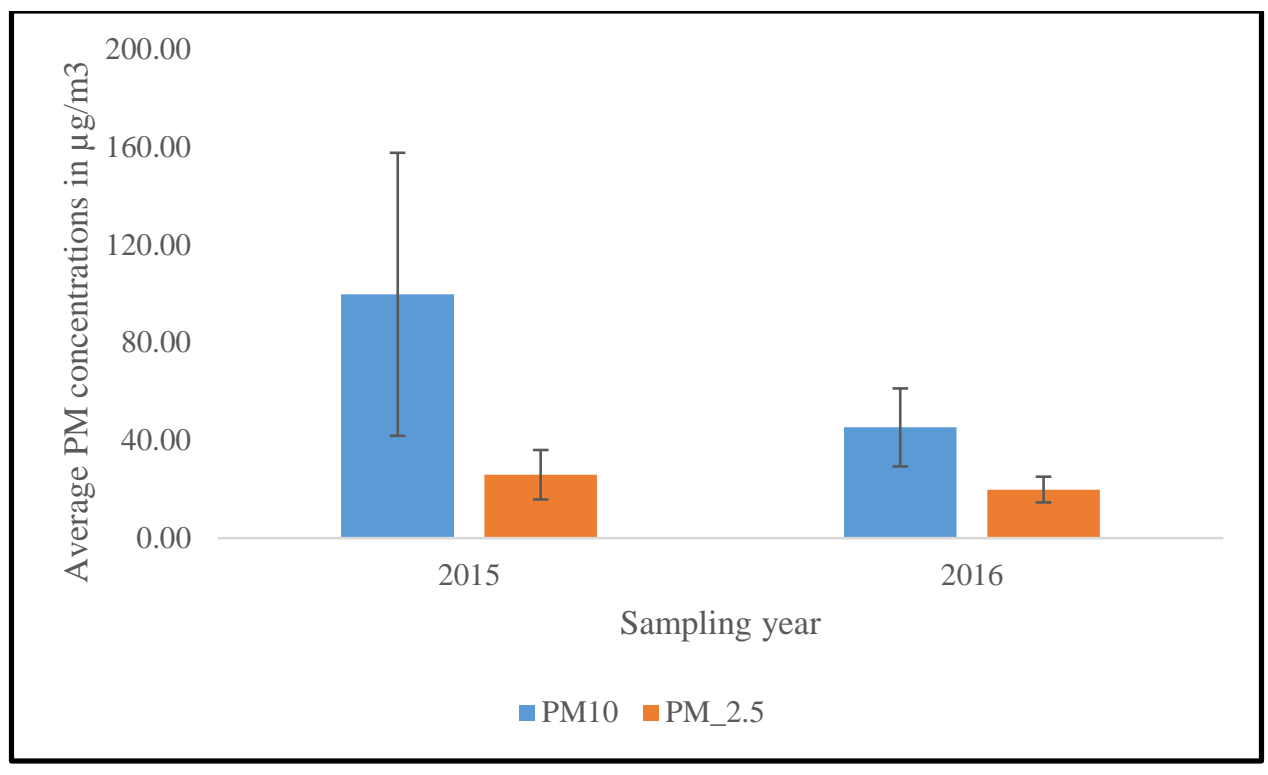

Figure 19. Yearly average PM concentrations in site 2.

Table 3

Stepwise regression analysis results of PM concentrations at site 2

\begin{tabular}{|c|c|c|}
\hline $\begin{array}{l}\text { Particulate } \\
\text { matter type }\end{array}$ & $\begin{array}{l}\text { Year of } \\
\text { sampling }\end{array}$ & Stepwise regression model equations \\
\hline \multirow{3}{*}{$\mathrm{PM}_{10}$} & $\begin{array}{c}2015 \& 2016 \\
\text { combined }\end{array}$ & $\begin{array}{c}\mathrm{PM}_{10}=72.08904-51.12641 \times \text { rainfall_in_mm } \\
\left(r^{2}=0.07\right)\end{array}$ \\
\hline & 2015 & $\begin{array}{c}\mathrm{PM}_{10}=99.74191-552.38530 \times \text { rainfall_in_mm } \\
\left(r^{2}=0.10\right)\end{array}$ \\
\hline & 2016 & $\begin{array}{c}\mathrm{PM}_{10}=70.44775-2.63587 \times \text { wind_speed }-35.85478 \times \\
\text { rainfall_in_mm } \\
\left(r^{2}=0.20\right)\end{array}$ \\
\hline \multirow{3}{*}{$\mathrm{PM}_{2.5}$} & $\begin{array}{c}2015 \& 2016 \\
\text { combined }\end{array}$ & No variables were statistically significant \\
\hline & 2015 & $\begin{array}{c}\mathrm{PM}_{2.5}=-14.91731+0.50329 \times \text { vehicle_count }+0.11719 \times \\
\text { wind_direction } \\
\left(r^{2}=0.58\right)\end{array}$ \\
\hline & 2016 & No variables were statistically significant \\
\hline
\end{tabular}

Notes: All variables here are significant at 0.15 level $(\mathrm{p}=0.15), \mathrm{r}^{2}$ values reported are model $\mathrm{r}^{2}$ values. 
The pooled average $\mathrm{PM}_{10}$ concentrations at site 2 were $70.42 \pm 38.37 \mu \mathrm{g} / \mathrm{m}^{3}$ and $\mathrm{PM}_{2.5}$ concentrations were $19.60 \pm 7.51 \mu \mathrm{g} / \mathrm{m}^{3}$ at standard pressure and temperature measured over a two-year sampling period. However, the $\mathrm{PM}_{10}$ concentration over a 24-h sampling ranged from $1.91 \mu \mathrm{g} / \mathrm{m}^{3}$ to $253.60 \mu \mathrm{g} / \mathrm{m}^{3}$ in 2015 and from $5.17 \mu \mathrm{g} / \mathrm{m}^{3}$ to $179.66 \mu \mathrm{g} / \mathrm{m}^{3}$ in 2016 , which is higher than the pooled average concentration. Similarly, $\mathrm{PM}_{2.5}$ concentration value ranged from $2.56 \mu \mathrm{g} / \mathrm{m}^{3}$ to $52.91 \mu \mathrm{g} / \mathrm{m}^{3}$ in 2015 and from $3.27 \mu \mathrm{g} / \mathrm{m}^{3}$ to $31.52 \mu \mathrm{g} / \mathrm{m}^{3}$ in 2016 . Figure 19 shows that the average $\mathrm{PM}_{10}$ concentrations in 2015 and 2016 were $99.74 \pm 57.88 \mu \mathrm{g} / \mathrm{m}^{3}$ and $45.29 \pm 15.95 \mu \mathrm{g} / \mathrm{m}^{3}$, respectively, and the average $\mathrm{PM}_{2.5}$ concentrations in 2015 and 2016 were $25.94 \pm 10.12 \mu \mathrm{g} / \mathrm{m}^{3}$ and $19.88 \pm 5.27 \mu \mathrm{g} / \mathrm{m}^{3}$, respectively. Same as site \#1, $\mathrm{t}$ the average $\mathrm{PM}_{10}$ concentrations in site \#2 were lower in 2016 than 2015. This may be attributed to lower traffic from decrease oil extraction activities in the sampling area.

In 2016, the average $\mathrm{PM}_{10}$ concentrations $\left(199.32 \pm 36.13 \mu \mathrm{g} / \mathrm{m}^{3}\right)$ and $\mathrm{PM}_{2.5}$ concentrations $(47.02 \pm 8.33 \mu \mathrm{g} . / \mathrm{m} 3)$ exceeded the NAAQS reference values $\left(\mathrm{PM}_{10}=150\right.$ $\mu \mathrm{g} / \mathrm{m}^{3} ; \mathrm{PM}_{2.5}=35 \mu \mathrm{g} / \mathrm{m}^{3}$ for 24 -hour sampling period). This was likely attributed to various factors i.e., high traffic on a loose gravel road and untreated road conditions. Also, traffic next to the sampling area likely contributed to higher PM concentration, except May 20-22, 2015 when gravel were applied to road. For example, on May 20-22, 2015, the average $\mathrm{PM}_{10}$ concentration was $151.4 \pm 58.32 \mu \mathrm{g} / \mathrm{m}^{3}$ that exceeded NAAQS PM 10 value (figure 18). The lower PM concentrations during June 24-26, 2015 was likely due to lower traffic and $2.88 \mathrm{~mm}$ rainfall. During July 13-15, 2015, there were higher PM concentrations compared to the amount of traffic which may be attributed to the ongoing underground cable/pipe installation about $30 \mathrm{~m}$ to the south of the road, as well as drier road conditions. Despite of having comparatively higher traffic count, the PM concentrations during May 11-13, 2016 were low likely due to the rainfall on May 
$10^{\text {th }}(12.5 \mathrm{~mm})$ and high wind speeds. A similar pattern was also observed during May 24-27, $2016\left(2.8 \mathrm{~mm}\right.$ rainfall on May $\left.25^{\text {th }}\right)$, June $14-16,2016\left(8.4 \mathrm{~mm}\right.$ rainfall on June $\left.13^{\text {th }}\right)$ and July 26-28, 2016 (2.88 $\mathrm{mm}$ rainfall).

From stepwise regression analysis, in 2015 , the $\mathrm{PM}_{10}$ concentrations had weak correlation $\left(\mathrm{r}^{2}=0.07\right)$ with rainfall but $\mathrm{PM}_{2.5}$ concentrations seemed to have a better relationship $\left(r^{2}=0.58\right)$ with vehicle count and wind direction $(\mathrm{p}=0.15)$. In 2016 , the $\mathrm{PM}_{10}$ concentrations had a weak correlation $\left(\mathrm{r}^{2}=0.20\right)$ with wind speed and rainfall, whereas $\mathrm{PM}_{2.5}$ had no association with other factors $(\mathrm{p}=0.15)$.

Figure 20 shows the average Total Suspended Particulates (TSP) concentrations in site 3. This site had three 1 mile segments: a) control section (with no additives or treatments), b) treated with brine, and c) treated with magnesium chloride. The TSP concentrations in control, brine treated section, and magnesium chloride treated section were $374.59 \pm 214.27 \mu \mathrm{g} / \mathrm{m}^{3}$, $407.66 \pm 220.84 \mu \mathrm{g} / \mathrm{m}^{3}$, and $200.94 \pm 90.11 \mu \mathrm{g} / \mathrm{m}^{3}$, respectively. Magnesium chloride was found to be most effective in reducing dust because of its hygroscopic property. It captures moisture from air and keeps the surface damp, thus, keeping particles together and minimizing emissions. Magnesium chloride is easily available, easy to apply, and inexpensive. On the other hand, brine was less effective in reducing dust. However, due to limited data, it may not be conclusive which treatment is more effective in reducing the dust. 


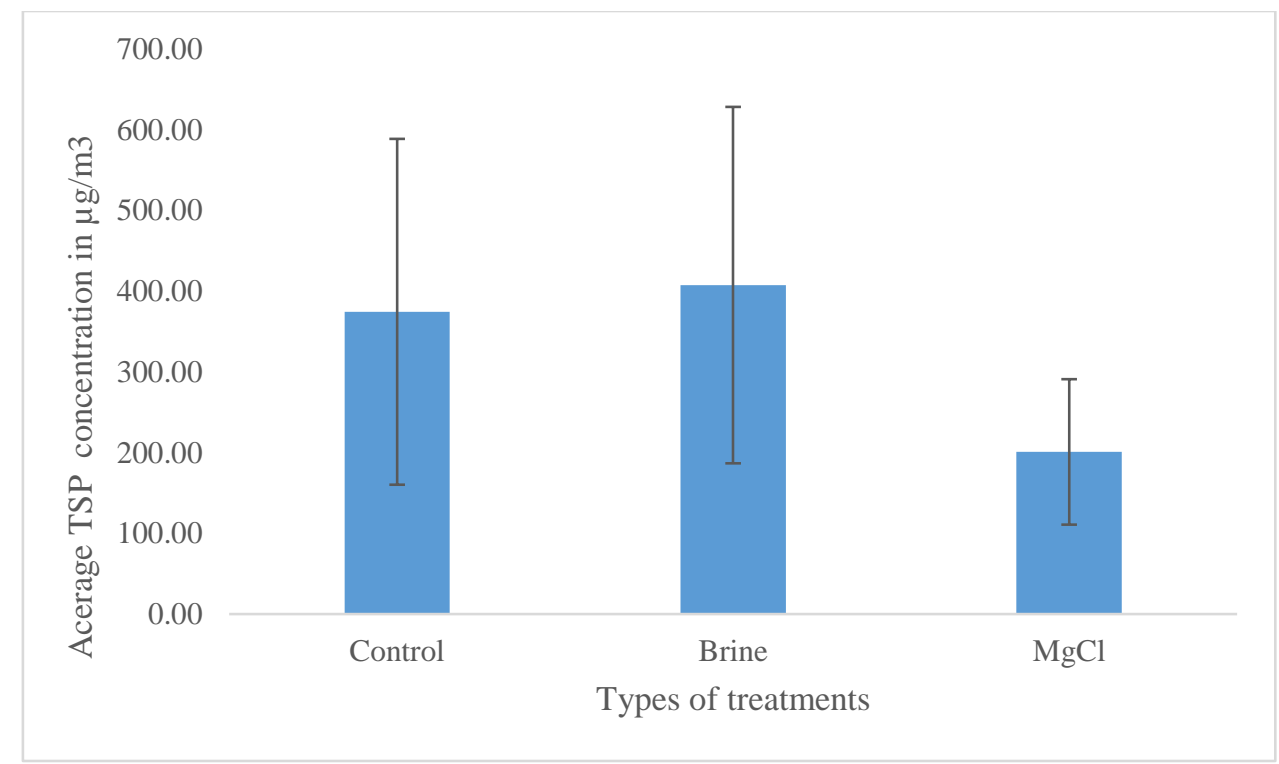

Figure 20. Average TSP concentrations in relation to types of treatments at site 3.

\subsection{Mineralogical characterization of particulate matter}

Based on elemental composition and morphology, 299 particles were analyzed using SEM-EDS. These particles were classified into three major groups: geogenic particles (derived from soil sediments, weathered rock surfaces), anthropogenic particles (particles derived from industrial and combustion activities), and biogenic particles (fungal hyphae with root outgrowth, organic plant fragments, living micro-organisms).

\subsubsection{Geogenic particles}

Most of the analyzed particles were found to be geogenic particles. These particles with crustal origin include silicates of iron, magnesium, aluminum, calcium, quartz, Fe/Ti oxides, calcium particles, chloride particles, carbonate minerals etc.

Quartz $\left(\mathrm{SiO}_{2}\right)$ is one of the most common minerals found in on earth's surface as it is a significant component of many sedimentary, metamorphic, and igneous rocks. Quartz can occur in many different colors, habits, and forms. Quartz crystals can be prismatic and can also appear in massive form with no definable shape with no visible aggregate or crystals. The source of 
quartz can be of both anthropogenic and natural origins. Quartz is characterized by high content of oxygen $(\mathrm{O})$ and silicon $(\mathrm{Si})(\mathrm{Si}+\mathrm{O}>90 \%$ by weight) summing up to $100 \%$ with an atomic ratio of $1 \mathrm{Si}$ to $2 \mathrm{O}$. Figure 21 shows a quartz particle with a spherical particle morphology with $\mathrm{Na}$ as trace element.

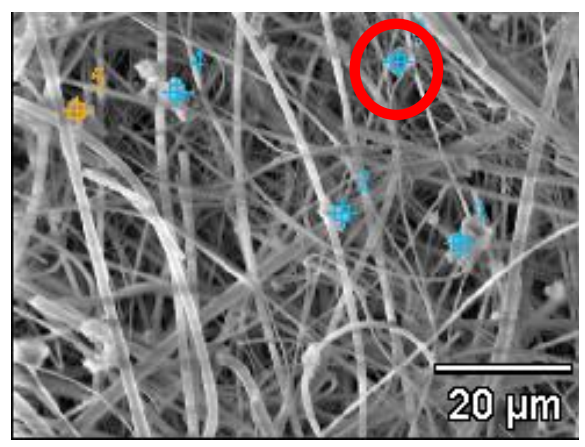

Full scale counts: 4673

158426-A9(8)_pt3

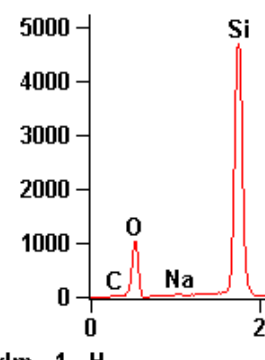

$\mathrm{klm}$ - 1 - H

keV

\begin{tabular}{|l|l|l|l|l|l|l|l|l|l|}
\hline Weight \% & $\mathrm{O}$ & $\mathrm{Na}$ & $\mathrm{Mg}$ & $\mathrm{Al}$ & $\mathrm{Si}$ & $\mathrm{K}$ & $\mathrm{Ca}$ & $\mathrm{Ti}$ & $\mathrm{Fe}$ \\
\hline 158426-A9(8)_pt3 & $53.06 \mathrm{~S}$ & 0.54 & & & 46.40 & & & & \\
\hline
\end{tabular}

\begin{tabular}{|l|l|l|l|l|l|}
\hline SEM ID Number & $\begin{array}{l}\text { Mineral } \\
\text { Group }\end{array}$ & Major Elements & Minor Elements & Morphology & Formulas from SEM data \\
\hline 158426-A9(8)_pt3 & Quartz & Si, O & Na & Spherical & $141 \mathrm{O}, 1 \mathrm{Na}, 70 \mathrm{Si}$ \\
\hline
\end{tabular}

Figure 21. Particulate matter identification from actual samples (Quartz)

Non-quartz silicates particles are identified by high $\mathrm{Si}$, aluminum (Al), O, and iron (Fe) content with variable content of sodium $(\mathrm{Na})$, magnesium $(\mathrm{Mg})$, potassium $(\mathrm{K})$, calcium $(\mathrm{Ca})$, titanium (Ti) with trace amounts of phosphorus $(\mathrm{P})$ and sulfur $(\mathrm{S})$, and sometimes carbon (C). Most particles in this group showed irregular, sub-spherical, and spherical morphology. Possible phases/minerals include feldspars, clays, oxides, carbonates, etc. Figure 22 shows possible identification of aluminosilicates group $\left(\mathrm{Al}_{2} \mathrm{SiO}_{5}\right)$ containing $\mathrm{O}, \mathrm{Si}$, and $\mathrm{Al}$ with lesser amounts of $\mathrm{Na}, \mathrm{Mg}, \mathrm{K}$, and $\mathrm{Ca}$. It showed irregular morphology. 
Oxide minerals are identified by high content of $\mathrm{O}$ and other elements like $\mathrm{Fe}, \mathrm{Al}$ with low amount of trace elements. They tend to have sub-spherical shape. Figure 23 shows an oxide mineral which has high $\mathrm{Al}$ and $\mathrm{O}$ content with trace amount of $\mathrm{Na}, \mathrm{Mg}, \mathrm{K}, \mathrm{Ca}$, and Fe. It likely is aluminum oxide.
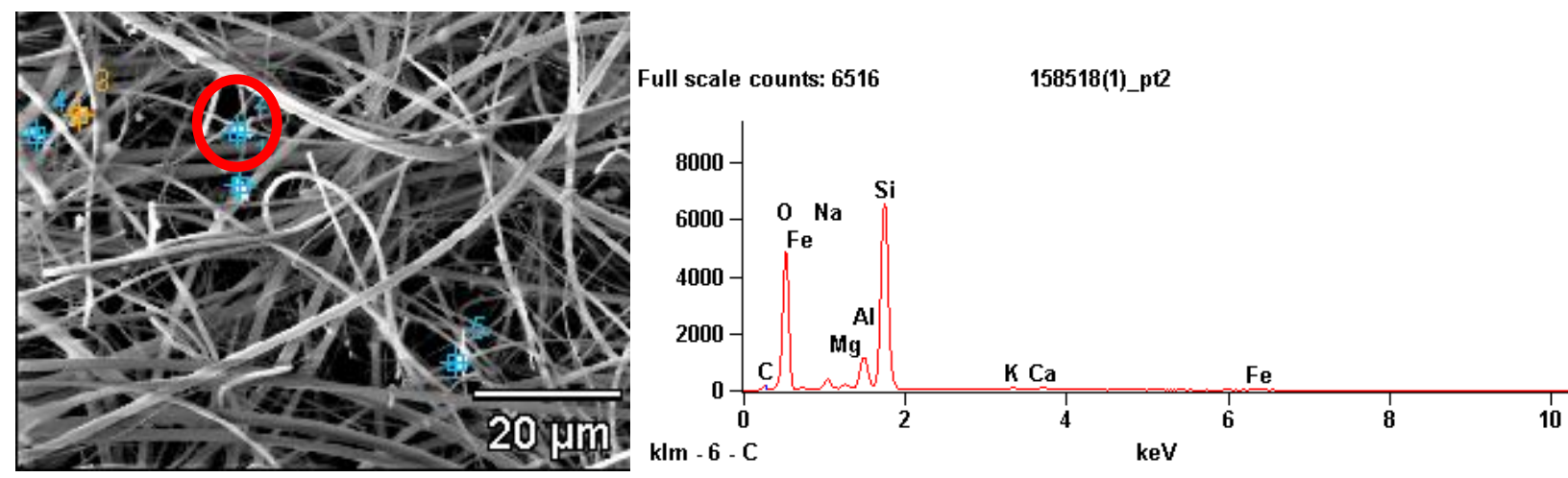

\begin{tabular}{|l|l|l|l|l|l|l|l|l|}
\hline Weight & $\mathrm{O}$ & $\mathrm{Na}$ & $\mathrm{Mg}$ & $\mathrm{Al}$ & $\mathrm{Si}$ & $\mathrm{K}$ & $\mathrm{Ca}$ & $\mathrm{Fe}$ \\
\hline $158518(1) \_\mathrm{pt} 2$ & $50.27 \mathrm{~S}$ & 2.76 & 0.56 & 5.49 & 37.64 & 0.88 & 1.28 & 1.11 \\
\hline
\end{tabular}

\begin{tabular}{|l|l|l|l|l|l|}
\hline SEM ID Number & $\begin{array}{l}\text { Mineral } \\
\text { Group }\end{array}$ & Major Elements & $\begin{array}{l}\text { Minor } \\
\text { Elements }\end{array}$ & Morphology & Formulas from SEM data \\
\hline 158518(1)_pt2 & Silicates & $\mathrm{O}, \mathrm{Si}, \mathrm{Al}$ & $\begin{array}{l}\mathrm{Na}, \mathrm{Mg}, \mathrm{K}, \mathrm{Ca}, \\
\mathrm{Fe}\end{array}$ & Irregular & $\begin{array}{l}158 \mathrm{O}, 6 \mathrm{Na}, 1 \mathrm{Mg}, 10 \mathrm{Al}, 67 \mathrm{Si}, 1 \mathrm{~K} \\
2 \mathrm{Ca}, 1 \mathrm{Fe}\end{array}$ \\
\hline
\end{tabular}

Figure 22. Particulate matter identification from actual samples (Silicate minerals aluminosilicates)
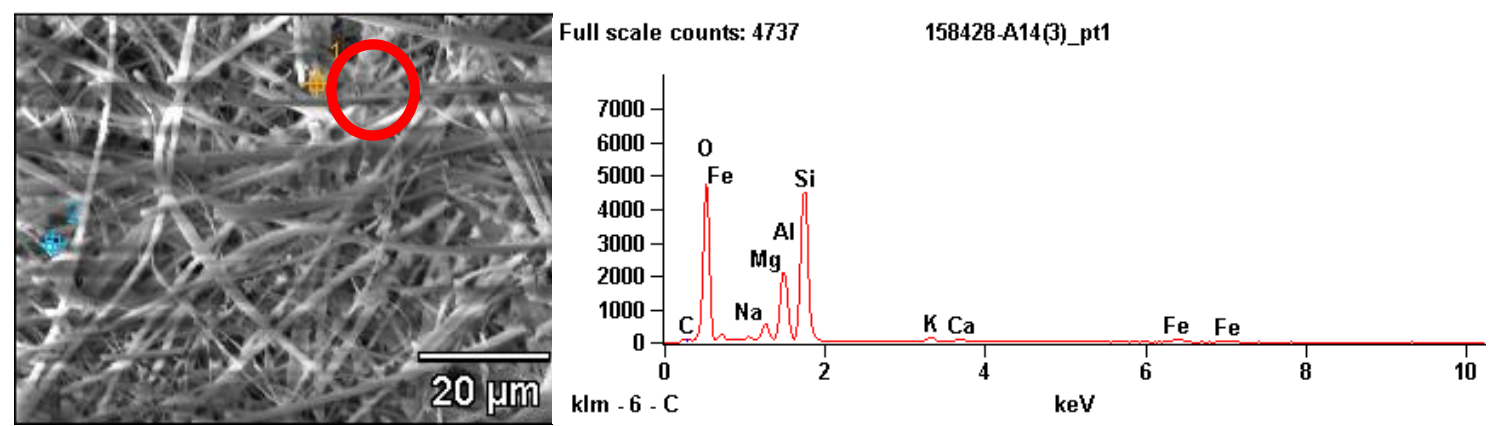

\begin{tabular}{|l|l|l|l|l|l|l|l|}
\hline Weight \% & $\mathrm{O}$ & $\mathrm{Na}$ & $\mathrm{Mg}$ & $\mathrm{Al}$ & $\mathrm{K}$ & $\mathrm{Ca}$ & $\mathrm{Fe}$ \\
\hline 158428-A14(3)_pt1 & $40.50 \mathrm{~S}$ & 2.35 & 6.36 & 31.36 & 3.02 & 2.42 & 13.98 \\
\hline
\end{tabular}

\begin{tabular}{|l|l|l|l|l|l|}
\hline $\begin{array}{l}\text { SEM ID } \\
\text { Number }\end{array}$ & $\begin{array}{l}\text { Mineral } \\
\text { Group }\end{array}$ & $\begin{array}{l}\text { Major } \\
\text { Elements }\end{array}$ & $\begin{array}{l}\text { Minor } \\
\text { Elements }\end{array}$ & Morphology & Formulas from SEM data \\
\hline 158428-A14(3) & Oxides & O, Al & $\begin{array}{l}\mathrm{Na}, \mathrm{Mg}, \mathrm{K}, \\
\mathrm{Ca}, \mathrm{Fe}\end{array}$ & $\begin{array}{l}\text { Sub- } \\
\text { spherical }\end{array}$ & $42 \mathrm{O}, 2 \mathrm{Na}, 4 \mathrm{Mg}, 19 \mathrm{Al}, 1 \mathrm{~K}, 1 \mathrm{Ca}, 4 \mathrm{Fe}$ \\
\hline
\end{tabular}

Figure 23. Particulate matter identification from actual samples (Silicate minerals - oxides) 


\subsubsection{Anthropogenic particles}

Anthropogenic particles include carbonaceous and industrial particles. Among industrial particles, the dominant metalliferous particles contain $\mathrm{Cr}>40 \%, \mathrm{Mn}>50 \%$ and $\mathrm{Ni}>10 \%$ by weight in combination with trace particles. Very few industrial particles were found in this study as the sampling sites were very far from industrial zones. Carbonaceous particles are significant as they contribute highly to the total mass of the particles. In figure 24 , soot was identified. It had high carbon content and low oxygen content. This type of particle can be produced from biomass and biofuel burning. Earlier studies show that this spherical particle can scatter and absorb light (Cong et al., 2008). Agricultural burning, tire residue, and waste incineration might be origin of these particles.

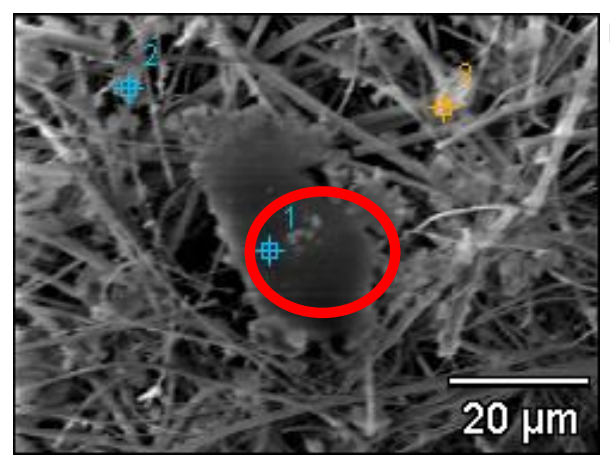

Full scale counts: 9480

158427-A14(2)_pt1

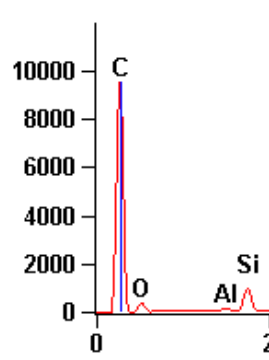

$k \mathrm{~km}-6-\mathrm{C}$

\begin{tabular}{|l|l|l|l|l|l|l|l|l|l|}
\hline Weight \% & $\mathrm{C}$ & $\mathrm{O}$ & $\mathrm{Na}$ & $\mathrm{Mg}$ & $\mathrm{Al}$ & $\mathrm{Si}$ & $\mathrm{K}$ & $\mathrm{Ca}$ & $\mathrm{Fe}$ \\
\hline 158427-A14(2)_pt1 & 95.66 & $2.30 \mathrm{~S}$ & & & 0.13 & 1.92 & & & \\
\hline
\end{tabular}

\begin{tabular}{|l|l|l|l|l|l|}
\hline SEM ID Numb & $\begin{array}{l}\text { Mineral } \\
\text { Group }\end{array}$ & $\begin{array}{l}\text { Major } \\
\text { Elements }\end{array}$ & $\begin{array}{l}\text { Minor } \\
\text { Elements }\end{array}$ & Morphology & Formulas from SEM data \\
\hline $158427-\mathrm{A} 14(2)$ & Soot & $\mathrm{C}, \mathrm{O}$ & $\mathrm{Al}, \mathrm{Si}$ & Sub-spherical/irregular & $1653 \mathrm{O}, 30 \mathrm{O}, 1 \mathrm{Al}, 14 \mathrm{Si}$ \\
\hline
\end{tabular}

Figure 24. Particulate matter identification from actual samples (Anthropogenic minerals - soot)

\subsubsection{Biogenic particles}

Particles of biological origin were quantified by the method used by Matthias-Maser and Jaenicke (Matthias-Maser \& Jaenicke, 1994). Both dead and alive biogenic aerosols contain minor amounts of $\mathrm{Na}, \mathrm{Mg}, \mathrm{K}, \mathrm{P}, \mathrm{Si}, \mathrm{Cl}, \mathrm{Al}$ and $\mathrm{Ca}$. These elements sum to approximately $10 \%$ of 
the whole weight of the particle. These elements are also essential trace elements present in plants (Artaxo \& Hansson, 1995). The rule to identify such particles is: biological aerosols will have combined weight percentage of greater than $75 \%$ of carbon and oxygen, and phosphorus, potassium and chlorine will have weight percentage of between $1 \%$ and $10 \%$ (Coz et al., 2010). $\mathrm{S}, \mathrm{Si}, \mathrm{Zn}$, and $\mathrm{Ca}$ are also tracers of biogenic materials. Figure 25 shows a round shaped outgrowth. It has a high carbon and oxygen content which sums up to more than $75 \%$ by weight with trace amounts of $\mathrm{K}, \mathrm{Na}, \mathrm{Cl}$, and $\mathrm{Ca}$. The silica content is probably from the filter fibers.
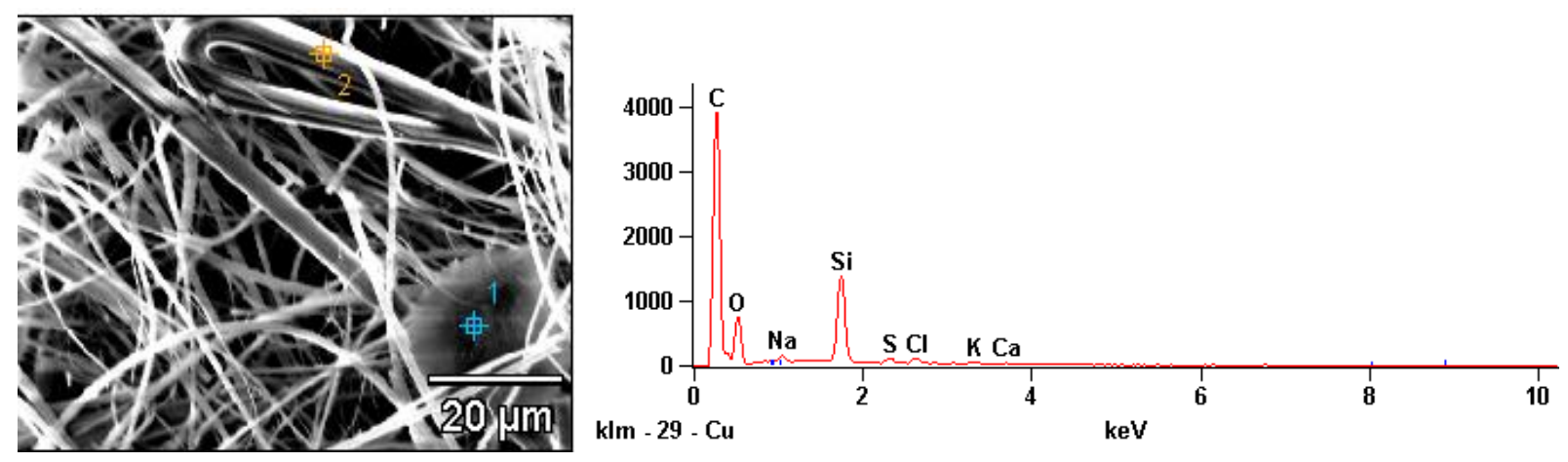

\begin{tabular}{|l|l|l|l|l|l|l|l|l|}
\hline Weight, \% & $\mathrm{C}$ & $\mathrm{O}$ & $\mathrm{Na}$ & $\mathrm{Si}$ & $\mathrm{S}$ & $\mathrm{Cl}$ & $\mathrm{K}$ & $\mathrm{Ca}$ \\
\hline 158426-A10(1)_pt1 & 26.32 & $71.87 \mathrm{~S}$ & 0.16 & 1.33 & 0.10 & 0.12 & 0.06 & 0.04 \\
\hline
\end{tabular}

\begin{tabular}{|l|l|l|l|l|l|}
\hline $\begin{array}{l}\text { SEM ID } \\
\text { Number }\end{array}$ & $\begin{array}{l}\text { Mineral } \\
\text { Group }\end{array}$ & Major Eleme & Minor Eleme & Morphology & Formulas from SEM data \\
\hline $158426-\mathrm{A} 10(1)$ & $\begin{array}{l}\text { Biological } \\
\text { group }\end{array}$ & $\mathrm{C}, \mathrm{O}$ & $\begin{array}{l}\mathrm{Si}, \mathrm{Na}, \mathrm{S}, \\
\mathrm{Cl}, \mathrm{K}, \mathrm{Ca}\end{array}$ & Round/spherical & $\begin{array}{l}2195 \mathrm{C}, 4500 \mathrm{O}, 7 \mathrm{Na}, 47 \mathrm{Si}, 3 \mathrm{~S}, \\
3 \mathrm{Cl}, 2 \mathrm{~K}, 1 \mathrm{Ca}\end{array}$ \\
\hline
\end{tabular}

Figure 25. Particulate matter identification (Biological particles)

Such biological particles include microorganisms and fragments of all varieties of living matter like viruses, bacteria, fungal growth, spores, pollen, plant debris, etc. (Cong et al., 2008; Coz et al., 2010; Matthias-Maser \& Jaenicke, 2000). 


\subsubsection{Relative amounts of identified particles}

Figure 26(a) shows that out of all particles analyzed, $46 \%$ were quartz, $36 \%$ were silicates, $9 \%$ were of biological origin followed by $7 \%$ oxides, $1 \%$ soot, and $1 \%$ chlorides. At site $1,53 \%$ of the particles were quartz followed by $33 \%$ silicates, $9 \%$ biological, $3 \%$ chlorides, etc. Among $\mathrm{PM}_{10}$ particles, majority of particles were silicates (41\%), and quartz (39\%), biological (12\%), etc. in site 1 .

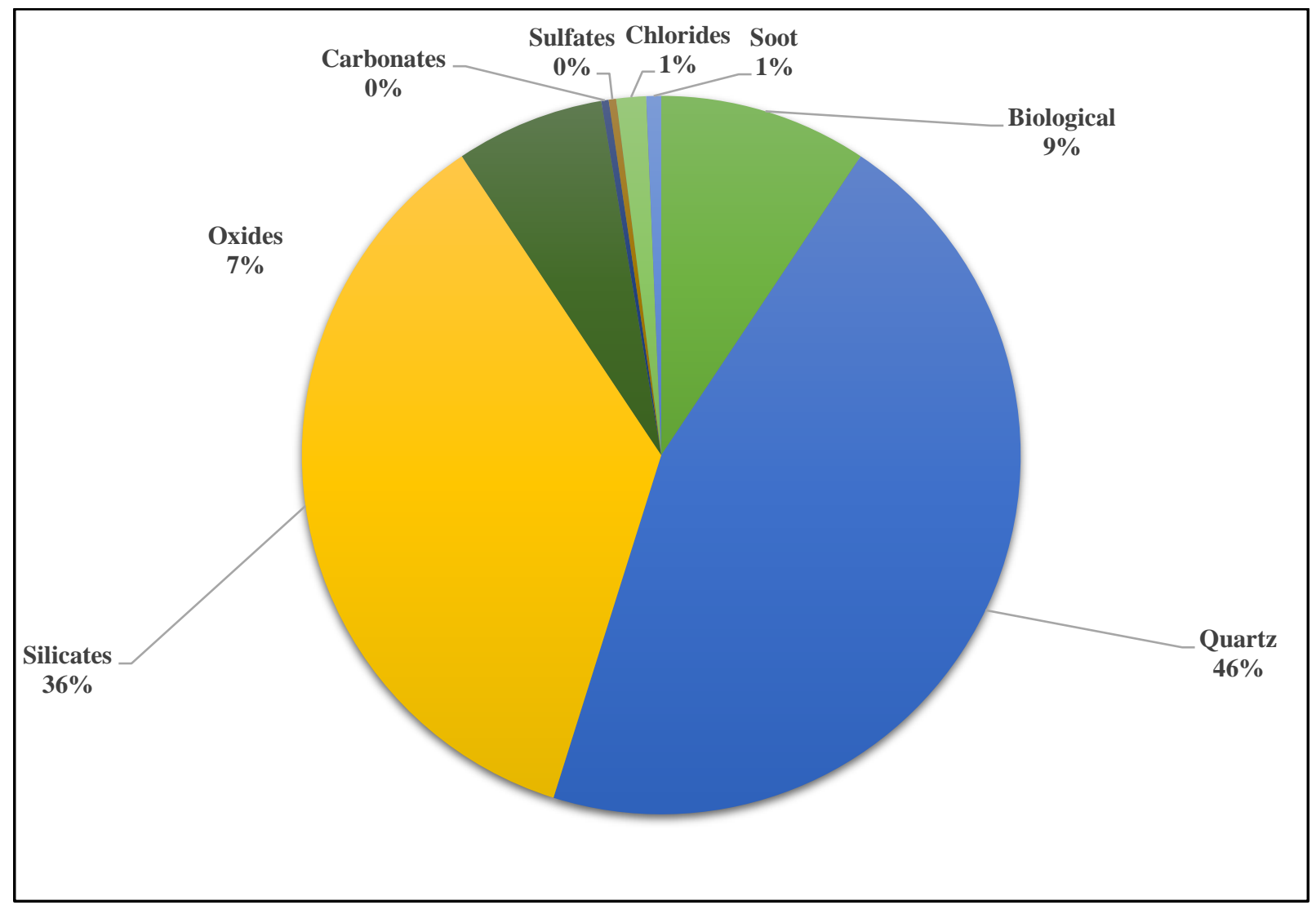

(a)

Figure 26. Relative amounts of minerals: (a) at all sites; (b) at site 1; (c) at site 2; (d) at site 1: $\mathrm{PM}_{10} ;(\mathrm{e})$ at site $1: \mathrm{PM}_{2.5} ;(\mathrm{f})$ at site $2: \mathrm{PM}_{10} ;(\mathrm{g})$ at site $2: \mathrm{PM}_{2.5}$ 


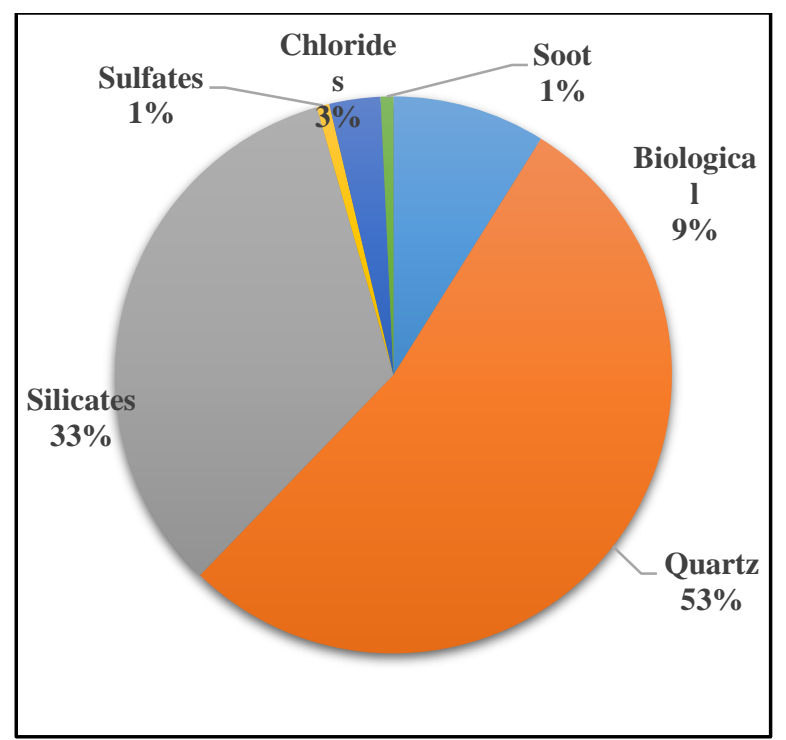

(b)

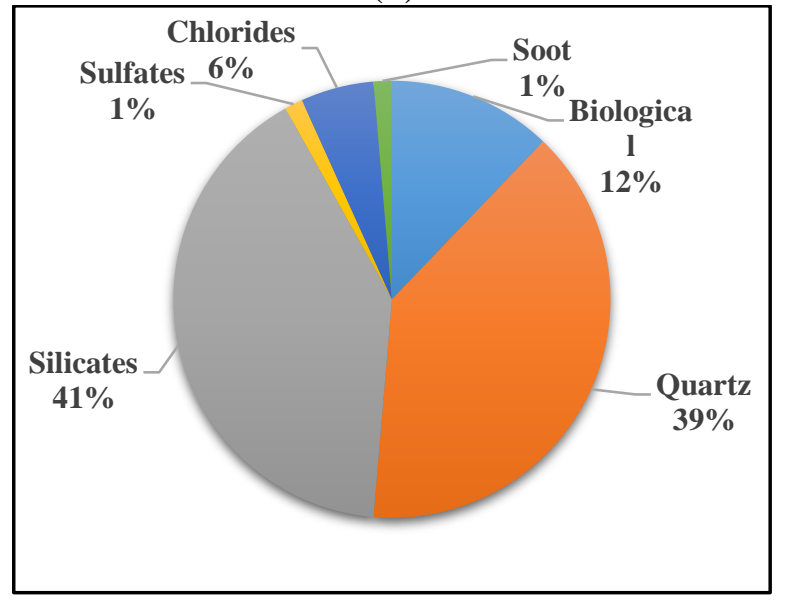

(d)

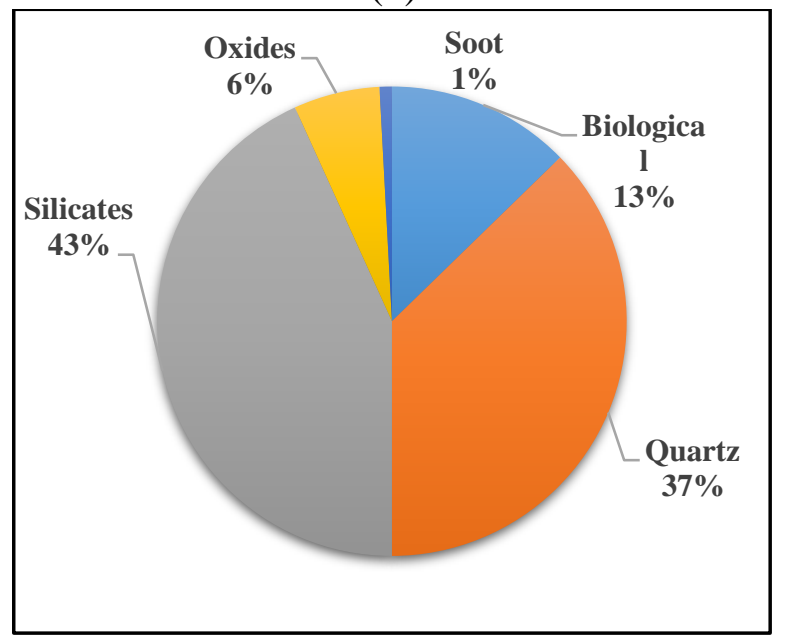

(f)

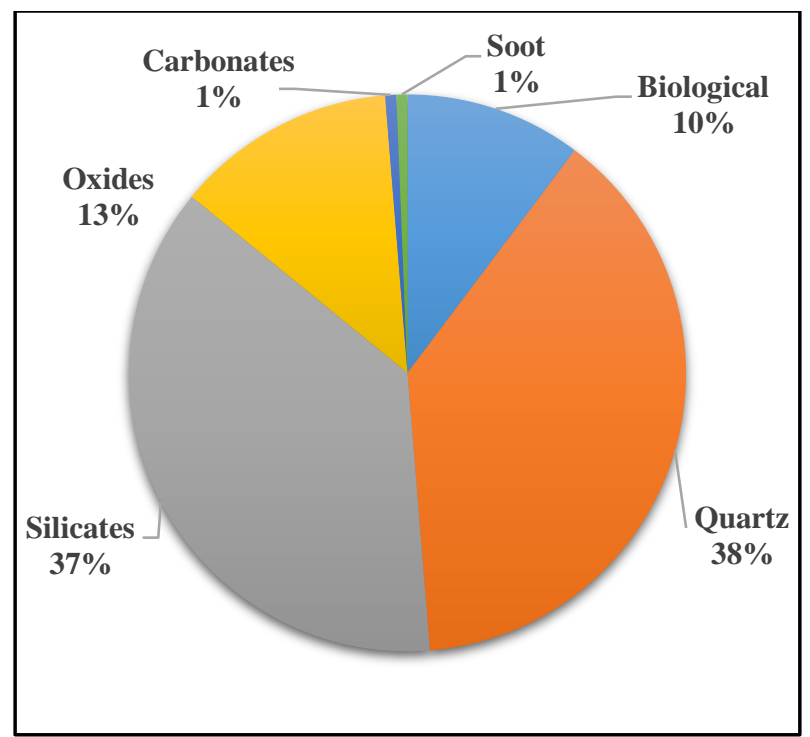

(c)

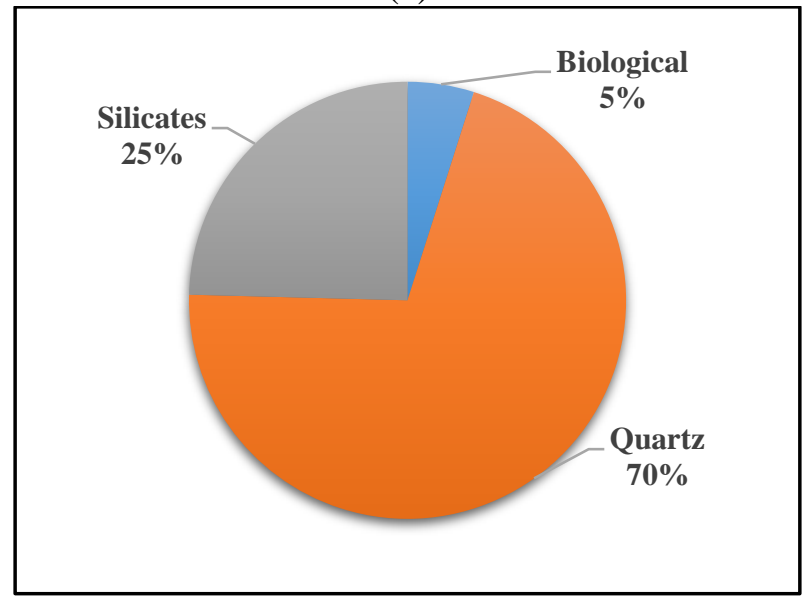

(e)

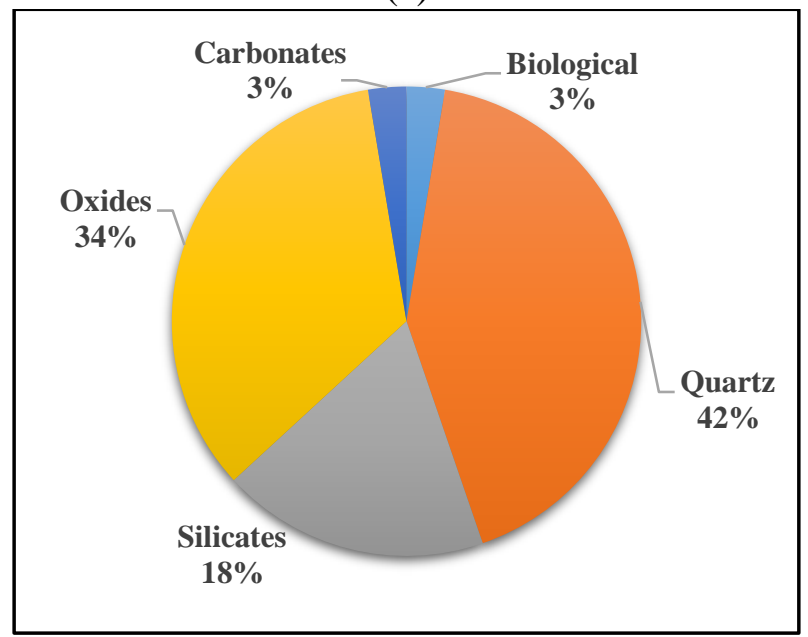

(g)

Figure 26. Relative amounts of minerals: (a) at all sites; (b) at site 1; (c) at site 2; (d) at site 1: $\mathrm{PM}_{10} ;(\mathrm{e})$ at site $1: \mathrm{PM}_{2.5}$; (f) at site 2: $\mathrm{PM}_{10} ;(\mathrm{g})$ at site 2: $\mathrm{PM}_{2.5}$ (continued) 
Among $\mathrm{PM}_{2.5}$ particles, majority of particles were quartz (70\%) followed by $25 \%$ silicates and $5 \%$ biological particles at site 1 . The prominence of quartz in $\mathrm{PM}_{2.5}$ particles is likely due to weathering action in the area by high traffic or transport of particles over long distances. At site 2, majority of particles were quartz (38\%) and silicates (37\%) followed by $10 \%$ biological particles, and $13 \%$ oxides, and with traces of carbonate minerals. Among $\mathrm{PM}_{10}$ particles in site 2 , silicates contributed to $43 \%$ followed by quartz (37\%), biological particles (13\%), oxides (6\%), etc. Among $\mathrm{PM}_{2.5}$ particles in site 2, majority of particles were quartz (42\%) and oxides (34\%) followed by $18 \%$ silicates, 3\% biological and 3\% carbonates particles.

\subsection{Elemental analysis of soil samples}

The soil samples were analyzed to determine their elemental composition with regard to sixty chemical elements by ICP-MS. Selected metals of interest were chosen because of their potential impact on the local environment and, essentially, crops and human health. There were several studies conducted in early 1980s which depict the elemental compositions of metals and their reference values in the soil (Shacklette \& Boerngen, 1984). In this study, concentrations of most of the metals were lower than the reference values. Additional data collected by the United States Geological Survey (USGS) Mineral Resources National Geochemical Survey (NGS) (USGS, 2003) (Sample ID: C - 250179, C - 237228, C-237239) and Smith et al. (2013) (Lab ID: C - 340224) were used to compare the measured values with these previously published values. Evaluation of the analytical data from this study showed few elements that appeared to be potentially influenced by dust from road traffic. However, some anomalies appeared to occur in the data from mercury $(\mathrm{Hg})$, lead $(\mathrm{Pb})$, and nickel $(\mathrm{Ni})$. Thus, these elements were examined more closely. Figure 27 and 28 show the average mercury $(\mathrm{Hg})$, and lead $(\mathrm{Pb})$ concentrations 
with increasing distances from the center of the road and their concentrations with respect to sampling dates.

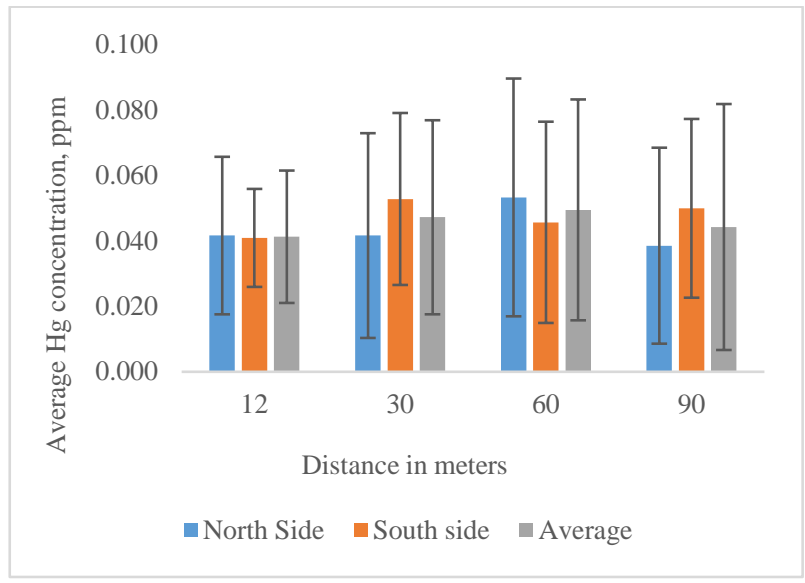

(a)

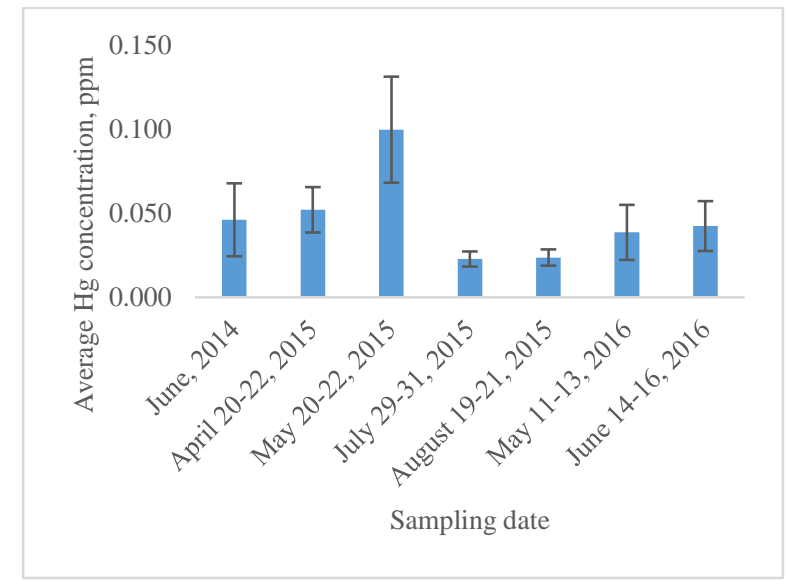

(b)

Figure 27. (a) Average mercury $(\mathrm{Hg})$ concentrations in ppm in soil at varying distances from the $\operatorname{road}(\mathrm{n}=8$ at $12 \mathrm{~m}, \mathrm{n}=6$ at $30 \mathrm{~m}, 60 \mathrm{~m}, 90 \mathrm{~m})$; (b) Average mercury (Hg) concentration in ppm with respect to the date of trip ( $n=8$ for all sampling dates except, $n=6$ for April 20-22, 2015).

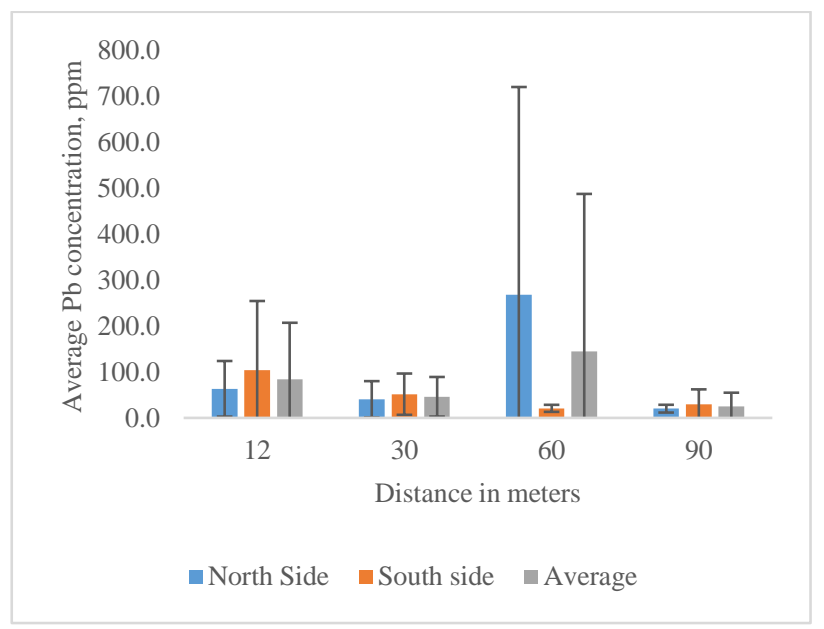

(a)

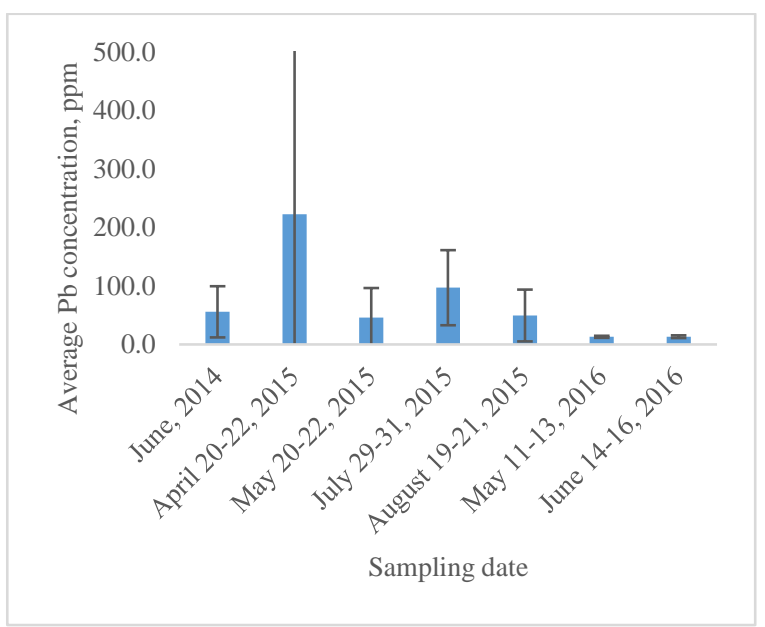

(b)

Figure 28. (a) Average lead $(\mathrm{Pb})$ concentrations in ppm in soil at varying distances from the road $(\mathrm{N}=8$ at $12 \mathrm{~m}, \mathrm{~N}=6$ at $30 \mathrm{~m}, 60 \mathrm{~m}, 90 \mathrm{~m})$; (b) Average lead $(\mathrm{Pb})$ concentration in ppm with respect to the date of trip ( $n=8$ for all sampling dates except, $n=6$ for April 20-22, 2015). 
The pooled average $\mathrm{Hg}$ concentration for the 7 sampling dates was $0.046 \pm 0.029 \mathrm{ppm}$ sampled over a period of three years. The concentration of $\mathrm{Hg}$ varied from 0.020 to $0.10 \mathrm{ppm}$. The reference value from NGS was found to be $0.020 \mathrm{ppm}$ and $0.07 \mathrm{ppm}$ (Smith et al., 2013). The average Hg concentrations on north side of the road were higher than that on the south side of the road. The mercury concentration is highest in the month of May, 2015 and then decreased significantly. There is a rise in $\mathrm{Hg}$ concentration in 2015, but the concentrations during 2014 and 2016 were low. It could be also due to disturbance of soil on the south side of the road as the underground cable/pipe installation activities were going on at that time.

The pooled average $\mathrm{Pb}$ concentration was $76.7 \pm 168 \mathrm{ppm}$ sampled over a period of three years. The reason of large error range is due to high $\mathrm{Pb}$ concentrations on April 20-22, 2015 sampling date (222.3 $\pm 391.5 \mathrm{ppm})$, and on July $29-31,2015$ sampling date $(97 \pm 64.2 \mathrm{ppm})$. The $\mathrm{Pb}$ concentrations varied from 6.4 to $435.9 \mathrm{ppm}$. The reference value from NGS was found to be $8.3 \pm 1.5 \mathrm{ppm}$ and $15.2 \mathrm{ppm}$ (Smith et al., 2013). The average $\mathrm{Pb}$ concentrations increased over distance to the $60 \mathrm{~m}$ sampling point and then dropped at $90 \mathrm{~m}$. The $\mathrm{Pb}$ concentrations, like $\mathrm{Hg}$, were much higher in 2015 than that of 2014 and 2016's. The high $\mathrm{Pb}$ concentrations during the 2015 sampling period could cause health issues to human working in the area and the animals that are feeding off the site, if the soil is ingested. As the soil $\mathrm{pH}$ (5.92) was below 6.50, it could also become available to plants.

Figure 29 and 30 show the average nickel (Ni), and calcium (Ca) concentrations with increasing distances from the center of the road and their concentrations with respect to sampling dates, respectively. 


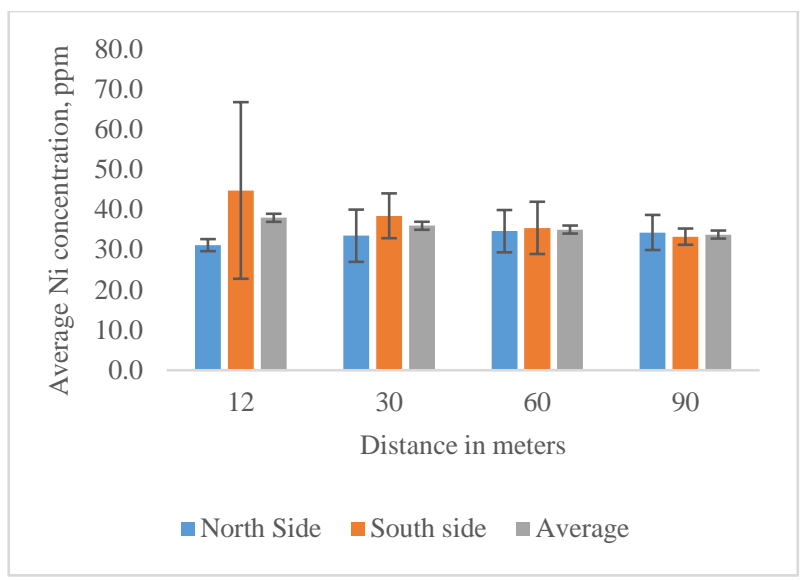

(a)

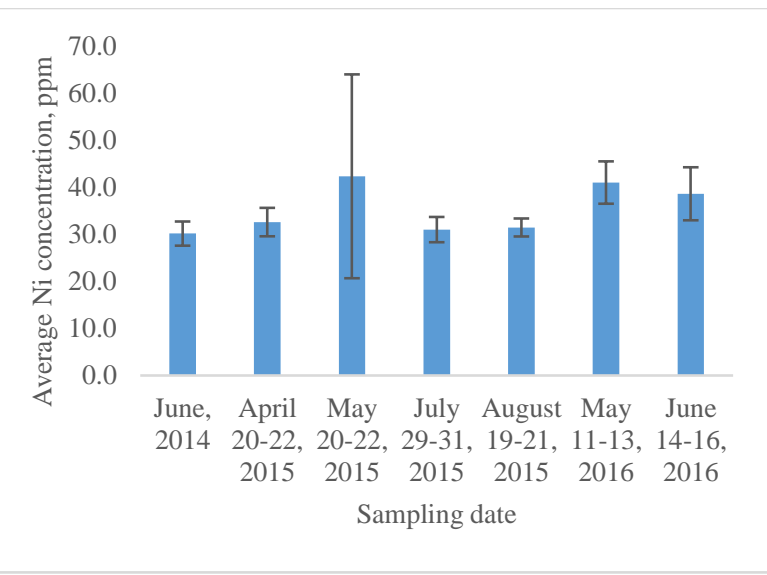

(b)

Figure 29. (a) Average nickel (Ni) concentrations in ppm in soil at varying distances from the $\operatorname{road}(\mathrm{N}=8$ at $12 \mathrm{~m}, \mathrm{~N}=6$ at $30 \mathrm{~m}, 60 \mathrm{~m}, 90 \mathrm{~m})$; (b) Average nickel (Ni) concentration in ppm with respect to the date of trip ( $n=8$ for all sampling dates except, $n=6$ for April 20-22, 2015).

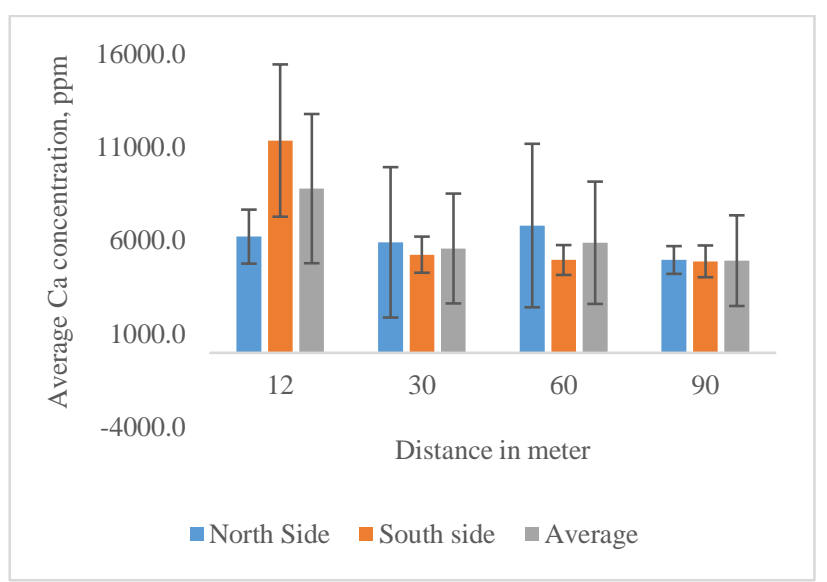

(a)

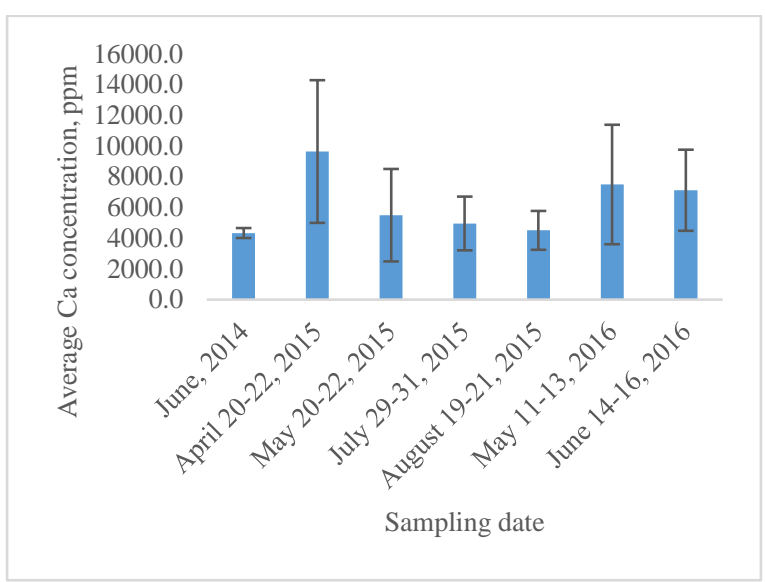

(b)

Figure 30. (a) Average calcium (Ca) concentrations in ppm in soil at varying distances from the $\operatorname{road}(\mathrm{N}=8$ at $12 \mathrm{~m}, \mathrm{~N}=6$ at $30 \mathrm{~m}, 60 \mathrm{~m}, 90 \mathrm{~m})$; (b) Average calcium (Ca) concentration in ppm with respect to the date of trip ( $n=8$ for all sampling dates except, $n=6$ for April 20-22, 2015).

The pooled average Ni concentration was $34.1 \pm 9.7$ ppm over a three-year sampling period. The Ni concentration values ranged from 18.2 to $97.5 \mathrm{ppm}$. The USGS NGS reference value of Ni concentration was $27.7 \pm 4.0 \mathrm{ppm}$ and $40.9 \mathrm{ppm}$ (Smith et al., 2013). This rise in $\mathrm{Ni}$ 
concentrations may be due to increased oil drilling in the area or due to natural variability in background specific to the sampling site.

The pooled average Ca concentration was $6273.89 \pm 6112.43$ ppm over a three-year sampling period. The Ca concentration values ranged from 3400 to $17000 \mathrm{ppm}$. The USGS NGS reference value for Ca concentration was $2529.7 \pm 1738.9$ ppm and 17000 ppm (Smith et al., 2013). This increase might be due to cable/pipe installation activities near the road which might have exposed lime (calcareous) geologic materials beneath the natural soil surface and brought it to the surface, subjected o displacement by wind or rainfall. 


\section{CONCLUSIONS AND FUTURE STUDY}

\subsection{Conclusions}

The primary objective of this project was to quantify particulate matter $\left(\mathrm{PM}_{10}, \mathrm{PM}_{2.5}\right)$ emissions from unpaved roads (treated vs untreated) in well development area in the Western North Dakota. Airmetrics miniVOL TM Tactical Air Samplers (Springfield, OR, USA) were used to quantify $\mathrm{PM}_{10}, \mathrm{PM}_{2.5}$, TSP at selected locations. The pooled average $\mathrm{PM}_{10}$ and $\mathrm{PM}_{2.5}$ concentrations were $30.84 \pm 14.19 \mu \mathrm{g} / \mathrm{m}^{3}$ and $14.08 \pm 6.56 \mu \mathrm{g} / \mathrm{m}^{3}$ from a periodically treated road (Site 1), respectively over a two-year sampling period. The $\mathrm{PM}_{10}$ emissions at site 1 were found to be weakly correlated with rainfall in $2015\left(\mathrm{r}^{2}=0.07\right)$ and moderately correlated with vehicle count, wind speed, wind direction, and rainfall in $2016\left(r^{2}=0.30\right)$ at $p=0.15$. Likewise, the $\mathrm{PM}_{2.5}$ emissions were strongly correlated with wind direction and rainfall in $2015\left(\mathrm{r}^{2}=0.51\right)$ and with vehicle count in $2016\left(\mathrm{r}^{2}=0.38\right)$. So, most of the time, the PM concentrations were high when the vehicle count was high and PM concentrations were low when there was a rainfall event. However, the average PM concentrations in 2015 were higher than 2016 but they were still below the NAAQS threshold values. In addition, the PM concentrations were low when magnesium chloride was applied on the road surface.

The pooled average $\mathrm{PM}_{10}$ and $\mathrm{PM}_{2.5}$ concentrations (over a two-year sampling period) were found to be $70.42 \pm 38.37 \mu \mathrm{g} / \mathrm{m}^{3}$ and $19.60 \pm 7.51 \mu \mathrm{g} / \mathrm{m}^{3}$ from an untreated loose gravel road (Site 2), respectively. There were some instances when the PM concentrations exceeded NAAQS values which could be due to construction activities on road or high vehicle count or new gravel application on the road or due to the untreated road surface. The $\mathrm{PM}_{10}$ concentrations were loosely correlated $\left(\mathrm{r}^{2}=0.10\right)$ with rainfall in 2015 and with wind speed and rainfall $\left(\mathrm{r}^{2}=\right.$ $0.20)$ in 2016 . The $\mathrm{PM}_{2.5}$ concentrations were strongly correlated $\left(\mathrm{r}^{2}=0.58\right)$ with vehicle count 
and wind direction in 2015 and no correlation was found in $2016(\mathrm{p}=0.15)$. The PM concentrations in 2016 were lower than that of 2015 because of a decrease in oil rigging activities in the sampling area.

Another location (site 3) was selected to determine the effectiveness of different types of treatments on the roads. Out of three treatments (control, brine, magnesium chloride), the most effective form of treatment was magnesium chloride.

Elemental composition, and morphology of samples were analyzed by scanning electron microscopy energy dispersive spectroscopy (SEM/EDS) which revealed there is a wide range of minerals, biological aerosols, and little amount of anthropogenic particles in the area. $46 \%$ of the particles analyzed was quartz which could have resulted from weathering processes of rocks, and $36 \%$ of the particles were found to be silicates which are basically constituents of roads in the sampling area. There were small amounts of biological particles (9\%), and oxides (7\%). Very limited amount of anthropogenic particles (Soot, 1\%) was found in the area. The relative amount of quartz was higher in site 1 than that of site 2 which could be due to accelerated weathering process from high number of traffic. Quartz and oxides were predominant in $\mathrm{PM}_{2.5}$ samples too.

Soil samples were analyzed using inductively coupled plasma - mass spectroscopy (ICPMS) to find out elemental compositions of metals present in the sampling area. To compare the measured value, elemental compositions of metals from three reference sites were compared with the United States Geological Survey (USGS) - National Geochemical Survey website and (Smith et al., 2013). It was found that the concentrations of most metal decreased with increasing distances from the center of the road to the north and south sides. Concentrations of the metals were higher in some cases which were likely due to increased oil drilling activities, higher traffic, disturbance of soil from underground cable installations, etc. The concentrations of most 
of the metals were higher in 2015 than that of 2014 and 2016, during which, traffic and oil activities were the highest. However, most of the metal concentrations were lower than the USGS reference values, thus may not pose any concern based on this study.

\subsection{Future study}

This study provided PM emissions along with their elemental composition of particles in the dust as well as elemental compositions of metals present in the soil in the study area. Further approach could be made to determine emission factor in the Western North Dakota. Another possible work could be a determination of "Emission Potential" for a road surface.

The overall dust distribution across the landscape could be demonstrated using remote sensing or by geographic information system. An air quality modeling could be done using AERMOD to predict the PM concentrations more accurately by taking topography, spatial data into consideration. Since, limited scientific information is available on dust suppressant, different dust mitigation and control techniques could be explored to find an economically viable as well as effective dust reduction method. Also, more studies could be carried out to find impacts of dust on the human living next to the oil development area, as well as the welfare of the animals. 


\section{REFERENCES}

Adachi, K., \& Tainosho, Y. (2004). Characterization of heavy metal particles embedded in tire dust. Environ Int, 30(8), 1009-1017. doi:10.1016/j.envint.2004.04.004

Ahmed, M., Chin, Y. H., Guo, X., \& Zhao, X.-M. Microwave assisted digestion followed by ICP-MS for determination of trace metals in atmospheric and lake ecosystem. Journal of Environmental Sciences. doi:http://dx.doi.org/10.1016/j.jes.2016.06.014

Artaxo, P., \& Hansson, H.-C. (1995). Size distribution of biogenic aerosol particles from the amazon basin. Atmospheric Environment, 29(3), 393-402. doi:http://dx.doi.org/10.1016/1352-2310(94)00178-N

Atlas, W. Cardinal directions and the compass rose. Retrieved from http://www.worldatlas.com/aatlas/infopage/comprose.htm

Ballester, F., Tenias, J., \& Perez-Hoyos, S. (2001). Air pollution and emergency hospital admissions for cardiovascular diseases in Valencia, Spain. Journal of Epidemiology and Community Health, 55(1), 57-65. doi:10.1136/jech.55.1.57

Blok, J. (2005). Environmental exposure of road borders to zinc. Science of The Total Environment, 348(1-3), 173-190. doi:http://dx.doi.org/10.1016/j.scitotenv.2004.12.073

Brook, R. D., Franklin, B., Cascio, W., Hong, Y., Howard, G., Lipsett, M., Luepker, R., Mittleman, M., Samet, J., Smith, S. C., \& Tager, I. (2004). Air Pollution and Cardiovascular Disease. Circulation, 109(21), 2655. Retrieved from http://circ.ahajournals.org/content/109/21/2655.abstract

Čabanova, K., Daniela Plachá, Jana Kukutschová, \& Kučerová, R. (2012). Chemical and Phase Analysis of Road Dust. Nanocon. 
Campbell, A., Oldham, M., Becaria, A., Bondy, S. C., Meacher, D., Sioutas, C., Misra, C., Mendez, L. B., \& Kleinman, M. (2005). Particulate Matter in Polluted Air May Increase Biomarkers of Inflammation in Mouse Brain. NeuroToxicology, 26(1), 133-140. doi:http://dx.doi.org/10.1016/j.neuro.2004.08.003

Cavanagh, J. E. (2006). Potential of vegetation to mitigate road generated air pollution - part 1 Review of background information. Retrieved from Lincoln, New Zealand:

Colls, J., \& Tiwary, A. (2010). Air Pollution: Measurement, Modelling and Mitigation, Third Edition (Third ed.). London, UK

Cong, Z., Kang, S., Dong, S., Liu, X., \& Qin, D. (2008). Elemental and individual particle analysis of atmospheric aerosols from high Himalayas. Environmental Monitoring and Assessment, 160(1), 323-335. doi:10.1007/s10661-008-0698-3

Cooper, C. D., \& Alley, F. C. (2002). Air pollution control: a design approach: Waveland Press. Coz, E., Artínano, B., Clark, L. M., Hernandez, M., Robinson, A. L., Casuccio, G. S., Lersch, T. L., \& Pandis, S. N. (2010). Characterization of fine primary biogenic organic aerosol in an urban area in the northeastern United States. Atmospheric Environment, 44(32), 39523962. doi:http://dx.doi.org/10.1016/j.atmosenv.2010.07.007

DMR, N. (2016). North Dakota Drilling and Production Statistics Retrieved from https://www.dmr.nd.gov/oilgas/stats/statisticsvw.asp. from Department of Mineral Resources, North Dakota https://www.dmr.nd.gov/oilgas/stats/statisticsvw.asp Dobb, E. (2013). The New Oil Landscape

The fracking frenzy in North Dakota has boosted the U.S. fuel supply—but at what cost? Retrieved from http://ngm.nationalgeographic.com/2013/03/bakken-shale-oil/dobb-text 
Dolan, R., Van Loon, J., Templeton, D., \& Paudyn, A. (1990). Assessment of ICP-MS for routine multielement analysis of soil samples in environmental trace element studies. Fresenius' Journal of Analytical Chemistry, 336(2), 99-105. doi:10.1007/BF00322545

Donham, K. J., \& Thelin, A. (2004). Agricultural medicine: Occupational and environmental health for the health professions: Victoria: Blackwell Publishing Asia.

Farmer, A. M. (1993). The effects of dust on vegetation—a review. Environmental Pollution, 79(1), 63-75. doi:http://dx.doi.org/10.1016/0269-7491(93)90179-R

Fuzzi, S., Baltensperger, U., Carslaw, K., Decesari, S., Denier van der Gon, H., Facchini, M. C., Fowler, D., Koren, I., Langford, B., Lohmann, U., Nemitz, E., Pandis, S., Riipinen, I., Rudich, Y., Schaap, M., Slowik, J. G., Spracklen, D. V., Vignati, E., Wild, M., Williams, M., \& Gilardoni, S. (2015). Particulate matter, air quality and climate: lessons learned and future needs. Atmos. Chem. Phys., 15(14), 8217-8299. doi:10.5194/acp-15-82172015

Gong, J. H., Linn, W. S., Sioutas, C., Terrell, S. L., Clark, K. W., Anderson, K. R., \& Terrell, L. L. (2003). Controlled Exposures of Healthy and Asthmatic Volunteers to Concentrated Ambient Fine Particles in Los Angeles. Inhalation Toxicology, 15(4), 305-325. doi:10.1080/08958370304455

Gonzales, H. B., Maghirang, R. G., Wilson, J. D., Razote, E. B., \& Guo, L. (2011). Measuring cattle feedlot dust using laser diffraction analysis. Transactions of ASABE, 54(6), 23192327.

Group, W. B. (1998). Airborne Particulate Matter: Pollution Prevention and Control. Retrieved from 
http://www.ifc.org/wps/wcm/connect/ab848080488557a8bd44ff6a6515bb18/HandbookA irborneParticulateMatterPollutionPreventionAndControl.pdf?MOD=AJPERES

Gunawardana, C., Goonetilleke, A., Egodawatta, P., Dawes, L., \& Kokot, S. (2012). Source characterisation of road dust based on chemical and mineralogical composition. Chemosphere, 87(2), 163-170. doi:http://dx.doi.org/10.1016/j.chemosphere.2011.12.012

Guney, M., Onay, T. T., \& Copty, N. K. (2010). Impact of overland traffic on heavy metal levels in highway dust and soils of Istanbul, Turkey. Environmental Monitoring and Assessment, 164(1), 101-110. doi:10.1007/s10661-009-0878-9

Guttikunda, S. (2008). A Primer on Air Quality Management. New Delhi.

Hefflin, B. J., Jalaludin, B., McClure, E., Cobb, N., Johnson, C. A., Jecha, L., \& Etzel, R. A. (1994). Surveillance for dust storms and respiratory diseases in Washington State, 1991. Arch Environ Health, 49(3), 170-174. doi:10.1080/00039896.1994.9940378

IUPAC. (1990). Glossary of Atmospheric Chemistry. International Union of Pure and Applied Chemistry (IUPAC) Terms 62, 2167-2219.

Kim, E., Park, H., Park, E. A., Hong, Y.-C., Ha, M., Kim, H.-C., \& Ha, E.-H. (2016). Particulate matter and early childhood body weight. Environment International, 94, 591-599. doi:http://dx.doi.org/10.1016/j.envint.2016.06.021

Koçak, M., Mihalopoulos, N., \& Kubilay, N. (2009). Origin and source regions of PM10 in the Eastern Mediterranean atmosphere. Atmospheric Research, 92(4), 464-474. doi:http://dx.doi.org/10.1016/j.atmosres.2009.01.005

Krasowsky, T., Daher, N., Sioutas, C., \& Ban-Weiss, G. (2015). Measurement of particulate matter emissions from in-use locomotives. Atmospheric Environment, 113, 187-196. doi:http://dx.doi.org/10.1016/j.atmosenv.2015.04.046 
Kuhn, T., Biswas, S., Fine, P. M., Geller, M., \& Sioutas, C. (2005). Physical and Chemical Characteristics and Volatility of PM in the Proximity of a Light-Duty Vehicle Freeway. Aerosol Science and Technology, 39(4), 347-357. doi:10.1080/027868290930024

Künzli, N., Jerrett, M., Mack, W. J., Beckerman, B., LaBree, L., Gilliland, F., Thomas, D., Peters, J., \& Hodis, H. N. (2005). Ambient Air Pollution and Atherosclerosis in Los Angeles. Environmental Health Perspectives, 113(2), 201-206. doi:10.1289/ehp.7523

Lanki, T., de Hartog, J. J., Heinrich, J., Hoek, G., Janssen, N. A. H., Peters, A., Stölzel, M., Timonen, K. L., Vallius, M., Vanninen, E., \& Pekkanen, J. (2006). Can We Identify Sources of Fine Particles Responsible for Exercise-Induced Ischemia on Days with Elevated Air Pollution? The ULTRA Study. Environmental Health Perspectives, 114(5), 655-660. doi:10.1289/ehp.8578

Li, W., Shao, L., Wang, Z., Shen, R., Yang, S., \& Tang, U. (2010). Size, composition, and mixing state of individual aerosol particles in a South China coastal city. Journal of Environmental Sciences, 22(4), 561-569. doi:http://dx.doi.org/10.1016/S10010742(09)60146-7

Ljepoja, D. (2015). Characterization of Road Dust in Western North Dakota. (Masters), North Dakota State University, Fargo, ND.

Mao, Y., Wilson, J. D., \& Kort, J. (2013). Effects of a shelterbelt on road dust dispersion. Atmospheric Environment, 79, 590-598. doi:http://dx.doi.org/10.1016/j.atmosenv.2013.07.015

Matthias-Maser, S., \& Jaenicke, R. (1994). Examination of atmospheric bioaerosol particles with radii $>0.2 \mu \mathrm{m}$. Journal of Aerosol Science, 25(8), 1605-1613. doi:http://dx.doi.org/10.1016/0021-8502(94)90228-3 
Matthias-Maser, S., \& Jaenicke, R. (2000). The size distribution of primary biological aerosol particles in the multiphase atmosphere. Aerobiologia, 16(2), 207-210. doi:10.1023/a:1007607614544

McCrea, P. R. (1984). An assessment of the effects of road dust on agricultural production systems / by P.R. McCrea. [Lincoln, N.Z.]: Agricultural Economics Research Unit, Lincoln College.

Middleton, N. J., \& Goudie, A. S. (2001). Saharan dust: sources and trajectories. Transactions of the Institute of British Geographers, 26(2), 165-181. doi:10.1111/1475-5661.00013

Moore, T. (1994). Hazardous Air Pollutants: Measuring in Micrograms. EPRI Journal, 19(1). Organic Life, R. (2015). Grow Healthy Food By Identifying + Treating These Common Plant Diseases. Retrieved from http://www.rodalesorganiclife.com/garden/common-plantdiseases

Pattey, E., \& Qiu, G. (2012). Trends in primary particulate matter emissions from Canadian agriculture. Journal of the Air \& Waste Management Association, 62(7), 737-747. doi:10.1080/10962247.2012.672058

Princeton. Environmental effects of Particulate Matter. Retrieved from https://www.princeton.edu/step/conferences-reports/reports/ch5.pdf

Riediker, M. (2007). Cardiovascular Effects of Fine Particulate Matter Components in Highway Patrol Officers. Inhalation Toxicology, 19, 99-105. doi:10.1080/08958370701495238

Samet, J., \& Krewski, D. (2007). Health Effects Associated With Exposure to Ambient Air Pollution. Journal of Toxicology and Environmental Health Part A, 70(3-1), 227-242. doi:10.1080/15287390600884644 
Schwartz, J. (1994). PM10, ozone, and hospital admissions for the elderly in Minneapolis-St. Paul, Minnesota. Arch Environ Health, 49(5), 366-374. doi:10.1080/00039896.1994.9954989

Schwartz, J., Laden, F., \& Zanobetti, A. (2002). The concentration-response relation between $\operatorname{PM}(2.5)$ and daily deaths. Environmental Health Perspectives, 110(10), 1025-1029. Retrieved from http://www.ncbi.nlm.nih.gov/pmc/articles/PMC1241029/

Schwindt, F. (2013). Investigation of methodologies to control dust on County roads in western North Dakota. Retrieved from

Sen-lin, L., Long-yi, S., Ming-hong, W., Zheng, J., Sen-lin, L., Long-yi, S., Ming-hong, W., \& Zheng, J. (2006). Mineralogical characterization of airborne individual particulates in

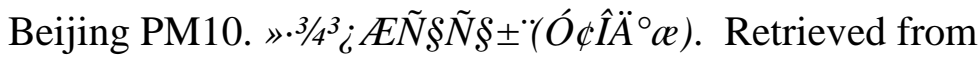
http://www.alljournals.cn/get_abstract_url.aspx?pcid=3FF3ABA7486768130C3FF83037 6F43B398E0C97F0FF2DD53\&cid=A7CA601309F5FED03C078BCE383971DC\&jid=6 CB1530875F53489BF1E81BD87B7F5E6\&aid=EE7D7853813D63B5CE509F264A21A 48A\&yid=37904DC365DD7266\&vid=13553B2D12F347E8\&iid=CA4FD0336C81A37 A\&sid=869807E2D7BED9EC\&eid=C36EC077A8A90308\&journal_id=10010742\&journal_name=Journalofenvironmentalsciences(China)\&referenced_num=0\&refer ence_num $=26$

Shacklette, H. T., \& Boerngen, J. G. (1984). Elemental Concentrations in Soils and Other Surficial Materials of the Conterminous United States (1270). Retrieved from

Shi, Z., Shao, L., Jones, T. P., Whittaker, A. G., Lu, S., Bérubé, K. A., He, T., \& Richards, R. J. (2003). Characterization of airborne individual particles collected in an urban area, a 
satellite city and a clean air area in Beijing, 2001. Atmospheric Environment, 37(29), 4097-4108. doi:http://dx.doi.org/10.1016/S1352-2310(03)00531-4

Smith, D. B., Cannon, W. F., Woodruff, L. G., Solano, F., Kilburn, J. E., \& Fey, D. L. (2013). Geochemical and Mineralogical Data for Soils of the Conterminous United States. Retrieved from http://pubs.usgs.gov/ds/801/

Squizzato, S., Masiol, M., Agostini, C., Visin, F., Formenton, G., Harrison, R. M., \& Rampazzo, G. (2016). Factors, origin and sources affecting PM1 concentrations and composition at an urban background site. Atmospheric Research, 180, 262-273. doi:http://dx.doi.org/10.1016/j.atmosres.2016.06.002

Stanek, L. W., Sacks, J. D., Dutton, S. J., \& Dubois, J.-J. B. (2011). Attributing health effects to apportioned components and sources of particulate matter: An evaluation of collective results. Atmospheric Environment, 45(32), 5655-5663. doi:http://dx.doi.org/10.1016/j.atmosenv.2011.07.023

Thurston, G. D., Ito, K., \& Lall, R. (2011). A source apportionment of U.S. fine particulate matter air pollution. Atmospheric Environment, 45(24), 3924-3936. doi:http://dx.doi.org/10.1016/j.atmosenv.2011.04.070

Todhunter, P. E., \& Cihacek, L. J. (1999). Historical reduction of airborne dust in the Red River Valley of the North. Journal of Soil and Water Conservation, 54(3), 543-551.

Toy, T. J., \& Foster, G. R. (2002). Soil erosion: processes, prediction, measurement and control. New York, NY: John Wiley \& Sons.

USDFR. (1999). The Code of Federal Regulations of the United States of America: U.S. Government Printing Office. 
USEIA. (2016). Crude Oil Production. Annual Report of United States Energy Information Administration. Retrieved from http://www.eia.gov/dnav/pet/pet_crd_crpdn_adc_mbblpd_m.htm

USEPA. (2015). NAAQS Table. Retrieved from https://www.epa.gov/criteria-airpollutants/naaqs-table

USEPA. (2016). Particulate Matter (PM) Basics. Retrieved from https://www.epa.gov/pmpollution/particulate-matter-pm-basics

USGS. (2003). USGS Mineral Resources: National Geochemical Survey. Retrieved from: http://mrdata.usgs.gov/geochemistry/ngs.html

Valavanidis, A., Fiotakis, K., \& Vlachogianni, T. (2008). Airborne particulate matter and human health: toxicological assessment and importance of size and composition of particles for oxidative damage and carcinogenic mechanisms. J Environ Sci Health C Environ Carcinog Ecotoxicol Rev, 26(4), 339-362. doi:10.1080/10590500802494538

Vallius, M., Lanki, T., Tiittanen, P., Koistinen, K., Ruuskanen, J., \& Pekkanen, J. (2003). Source apportionment of urban ambient PM25 in two successive measurement campaigns in Helsinki, Finland. Atmospheric Environment, 37(5), 615-623.

Volk, H. E., Lurmann, F., Penfold, B., Hertz-Picciotto, I., \& McConnell, R. (2013). Trafficrelated air pollution, particulate matter, and autism. JAMA Psychiatry, 70(1), 71-77. doi:10.1001/jamapsychiatry.2013.266

WHO. (1999). Hazard prevention and control in the work environment: Airborne dust. Retrieved from http://www.who.int/occupational_health/publications/airdust/en/ 


\section{APPENDIX A}

Table A1

Airmetrics sampler calibration constants

\begin{tabular}{|r|r|r|r|r|}
\hline \multirow{2}{*}{ Sampler No. } & \multicolumn{2}{|c|}{2015} & \multicolumn{2}{|c|}{2016} \\
\cline { 2 - 5 } & $\begin{array}{c}\text { Regression } \\
\text { slope, } \mathrm{m}_{\mathrm{vol}}\end{array}$ & $\begin{array}{c}\text { Intersect, } \\
\mathrm{b}_{\mathrm{vol}}\end{array}$ & $\begin{array}{c}\text { Regression slope, } \\
\mathrm{m}_{\mathrm{vol}}\end{array}$ & $\begin{array}{c}\text { Intersect, } \\
\mathrm{b}_{\mathrm{vol}}\end{array}$ \\
\hline 5941 & 1.1775 & -0.37940 & 1.1156 & $\begin{array}{r}- \\
0.32850\end{array}$ \\
\hline 5939 & 1.1650 & -0.34250 & 1.1432 & $\begin{array}{r}- \\
0.49800\end{array}$ \\
\hline 5942 & 1.1805 & -0.41300 & 1.1562 & $\begin{array}{r}- \\
0.50470\end{array}$ \\
\hline 5940 & 1.1850 & -0.39650 & 1.1600 & - \\
\hline 6786 & 1.1941 & -0.54200 & 1.1153 & 0.42130 \\
\hline 6785 & 1.1861 & -0.46850 & 1.1336 & - \\
\hline 6784 & 1.1862 & -0.48690 & 1.1369 & - \\
\hline 6787 & 1.1798 & -0.43530 & 1.1228 & 0.54560 \\
\hline & & & & - \\
\hline
\end{tabular}

A2. Particulate matter concentration at site 1

S1-10 means that the sampler is on the south side ( $\mathrm{N}$ means north) of the road about 38 feet from the center of the road with $\mathrm{PM}_{10}$ configuration. S2-10 means the sampler is 100 feet from the center of the road. S1-2.5 means a sampler with $\mathrm{PM}_{2.5}$ configuration. $\mathrm{N}-10$ refers to a sampler at about 38 feet from the center of the road to the north side with a $\mathrm{PM}_{10}$ configuration. Wind direction is expressed in cardinal degree system which was converted to compass (Atlas). 
Table A2

Particulate matter concentration at site 1

\begin{tabular}{|c|c|c|c|c|c|c|c|c|c|c|c|c|c|c|}
\hline \multirow[t]{2}{*}{ Date } & \multicolumn{2}{|c|}{ Time } & \multirow[t]{2}{*}{$\begin{array}{c}\text { Sampler } \\
\text { ID }\end{array}$} & \multirow[t]{2}{*}{$\begin{array}{c}\text { Filter } \\
\text { No. }\end{array}$} & \multirow{2}{*}{$\begin{array}{c}\begin{array}{c}\text { Net } \\
\text { Mass }\end{array} \\
M_{\mathrm{PM}} \\
(\mu \mathrm{g})\end{array}$} & \multirow{2}{*}{$\begin{array}{c}\begin{array}{l}\text { Run } \\
\text { Time }\end{array} \\
\text { (hrs) }\end{array}$} & \multirow{2}{*}{$\begin{array}{c}\begin{array}{c}\text { Flow } \\
\text { Rate }\end{array} \\
1_{\mathrm{sp}} \\
(\mathrm{lpm})\end{array}$} & \multirow{2}{*}{$\begin{array}{c}\begin{array}{c}\text { Actual } \\
\text { Temp }\end{array} \\
{ }^{\circ} \mathrm{C}\end{array}$} & \multirow{2}{*}{$\begin{array}{c}\text { Actual } \\
\text { Pressure } \\
(\mathrm{mm} \\
\mathrm{Hg}) \\
\end{array}$} & \multirow{2}{*}{$\begin{array}{r}\begin{array}{r}\text { STD } \\
\text { Vol }\end{array} \\
\left(\mathrm{m}^{3}\right)\end{array}$} & \multirow{2}{*}{$\begin{array}{c}\text { STD } \\
\text { Conc. } \\
\left(\mu \mathrm{g} / \mathrm{m}^{3}\right)\end{array}$} & \multirow[t]{2}{*}{$\begin{array}{l}\text { Vehicle } \\
\text { Count }\end{array}$} & \multirow{2}{*}{$\begin{array}{c}\text { Wind } \\
\text { Speed } \\
\text { mph }\end{array}$} & \multirow{2}{*}{$\begin{array}{c}\text { Wind } \\
\text { Direction } \\
\text { Cardinal } \\
\text { degree }\end{array}$} \\
\hline & Initial & Final & & & & & & & & & & & & \\
\hline $\begin{array}{l}4 / 20 / \\
2015\end{array}$ & 146.1 & 167.3 & $\begin{array}{c}5941 \\
S 1-10\end{array}$ & A-1 & 115 & 21.2 & 5.0 & 4.916 & 693.144 & 6.93 & 16.60 & \multirow{4}{*}{86} & & \\
\hline $\begin{array}{l}4 / 20 / \\
2015\end{array}$ & 145.0 & 166.3 & $\begin{array}{c}5939 \\
\text { S1-2.5 }\end{array}$ & A-4 & 75 & 21.3 & 5.0 & 4.916 & 693.144 & 6.93 & 10.82 & & & \\
\hline $\begin{array}{l}4 / 20 / \\
2015\end{array}$ & 146.5 & 167.5 & $\begin{array}{c}5942 \\
\text { S2-10 }\end{array}$ & A-2 & 143 & 21.0 & 5.0 & 4.916 & 693.144 & 6.84 & 20.91 & & & \\
\hline $\begin{array}{l}4 / 20 / \\
2015\end{array}$ & 168.6 & 190.0 & $\begin{array}{l}5940 \\
\mathrm{~N}-10\end{array}$ & A-3 & 137 & 21.4 & 5.0 & 4.916 & 693.144 & 7.02 & 19.52 & & & \\
\hline $\begin{array}{l}4 / 21 / \\
2015\end{array}$ & 167.3 & 189.3 & $\begin{array}{c}5941 \\
S 1-10\end{array}$ & A-11 & 283 & 22.0 & 5.0 & 2.296 & 696.659 & 7.24 & 39.08 & \multirow{4}{*}{87} & & \\
\hline $\begin{array}{l}4 / 21 / \\
2015\end{array}$ & 166.3 & 188.3 & $\begin{array}{c}5939 \\
S 1-2.5\end{array}$ & A-10 & 110 & 22.0 & 5.0 & 2.296 & 696.659 & 7.21 & 15.26 & & & \\
\hline $\begin{array}{l}4 / 21 / \\
2015\end{array}$ & 167.5 & 189.8 & $\begin{array}{c}5942 \\
\text { S2-10 }\end{array}$ & A-9 & 273 & 22.3 & 5.0 & 2.296 & 696.659 & 7.32 & 37.31 & & & \\
\hline $\begin{array}{l}4 / 21 / \\
2015\end{array}$ & 190.0 & 212.0 & $\begin{array}{l}5940 \\
\mathrm{~N}-10\end{array}$ & A-12 & 292 & 22.0 & 5.0 & 2.296 & 696.659 & 7.27 & 40.17 & & & \\
\hline $\begin{array}{l}5 / 20 / \\
2015\end{array}$ & 189.4 & 210.1 & $\begin{array}{c}5941 \\
S 1-10\end{array}$ & A-18 & 190 & 20.7 & 5.0 & 14.415 & 702.676 & 6.70 & 28.37 & \multirow{4}{*}{57} & & \\
\hline $\begin{array}{l}5 / 20 / \\
2015\end{array}$ & 188.3 & 209.2 & $\begin{array}{c}5939 \\
S 1-2.5\end{array}$ & A-17 & 51 & 20.9 & 5.0 & 14.415 & 702.676 & 6.73 & 7.58 & & & \\
\hline $\begin{array}{l}5 / 20 / \\
2015\end{array}$ & 189.7 & 210.8 & $\begin{array}{c}5942 \\
\text { S2-10 }\end{array}$ & A-19 & 184 & 21.1 & 5.0 & 14.415 & 702.676 & 6.80 & 27.04 & & & \\
\hline $\begin{array}{l}5 / 20 / \\
2015\end{array}$ & 212.0 & 233.0 & $\begin{array}{l}5940 \\
\mathrm{~N}-10\end{array}$ & A-20 & 199 & 21.0 & 5.0 & 14.415 & 702.676 & 6.82 & 29.18 & & & \\
\hline
\end{tabular}


Table A2. Particulate matter concentration at site 1 (continued)

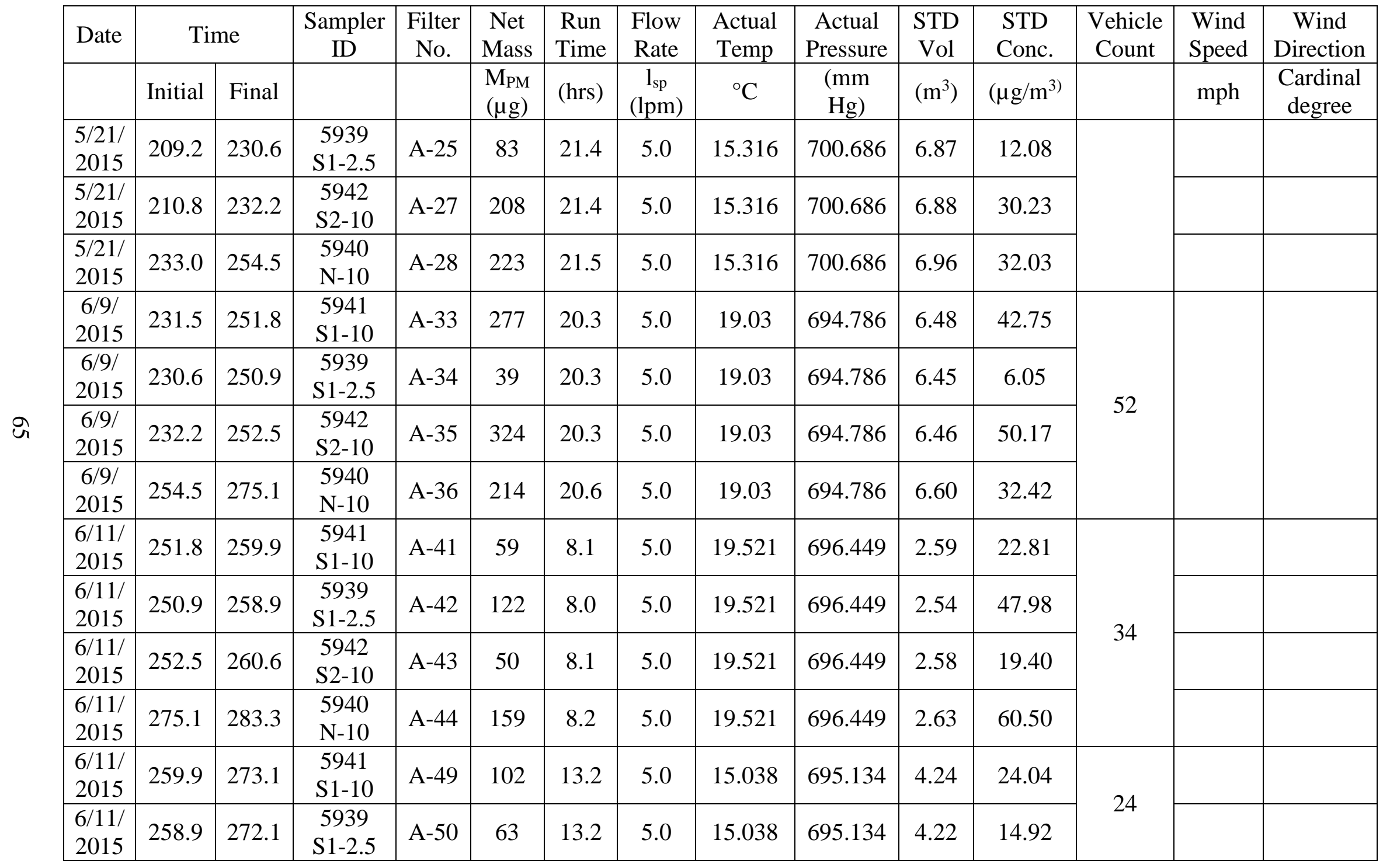


Table A2. Particulate matter concentration at site 1 (continued)

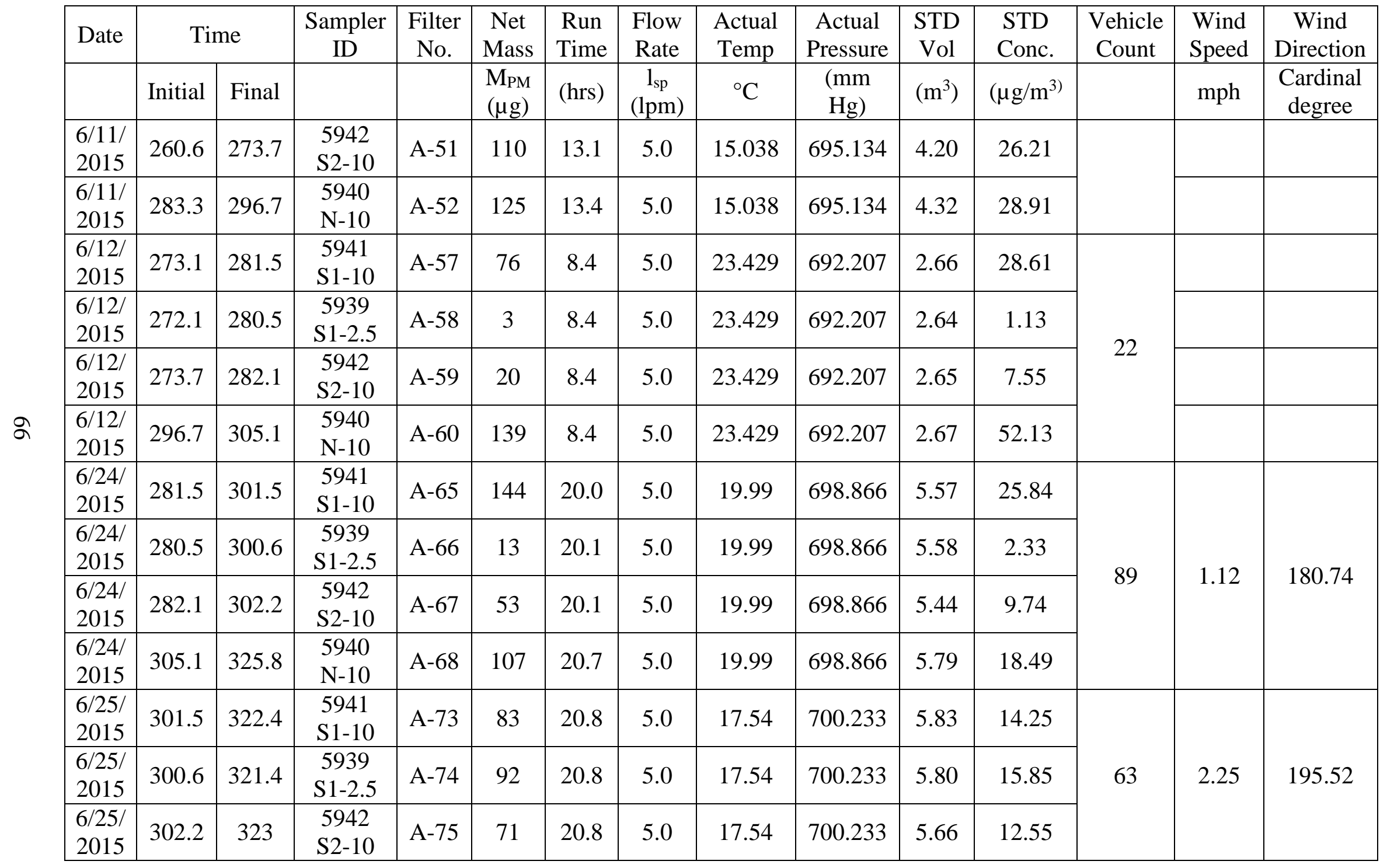


Table A2. Particulate matter concentration at site 1 (continued)

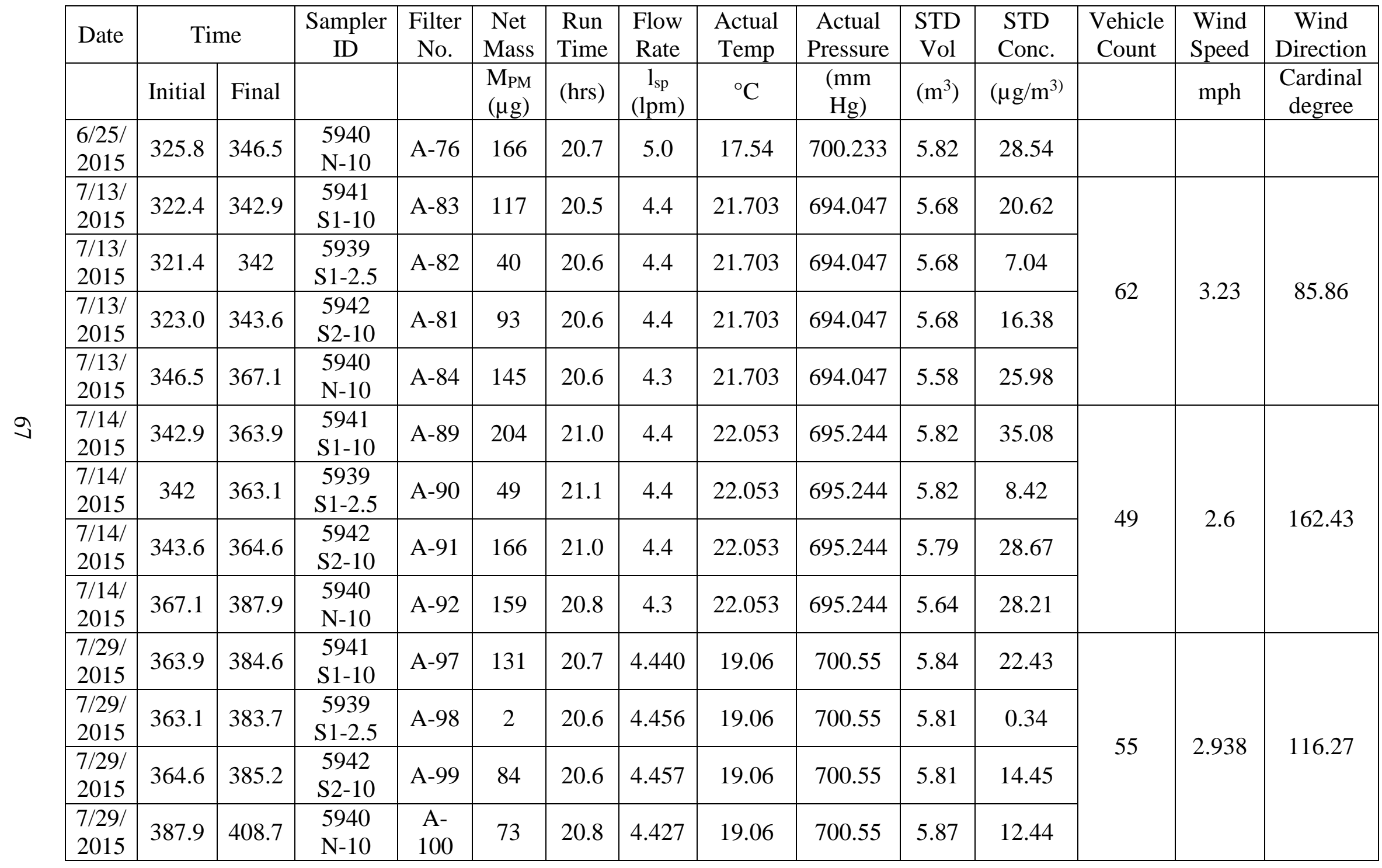


Table A2. Particulate matter concentration at site 1 (continued)

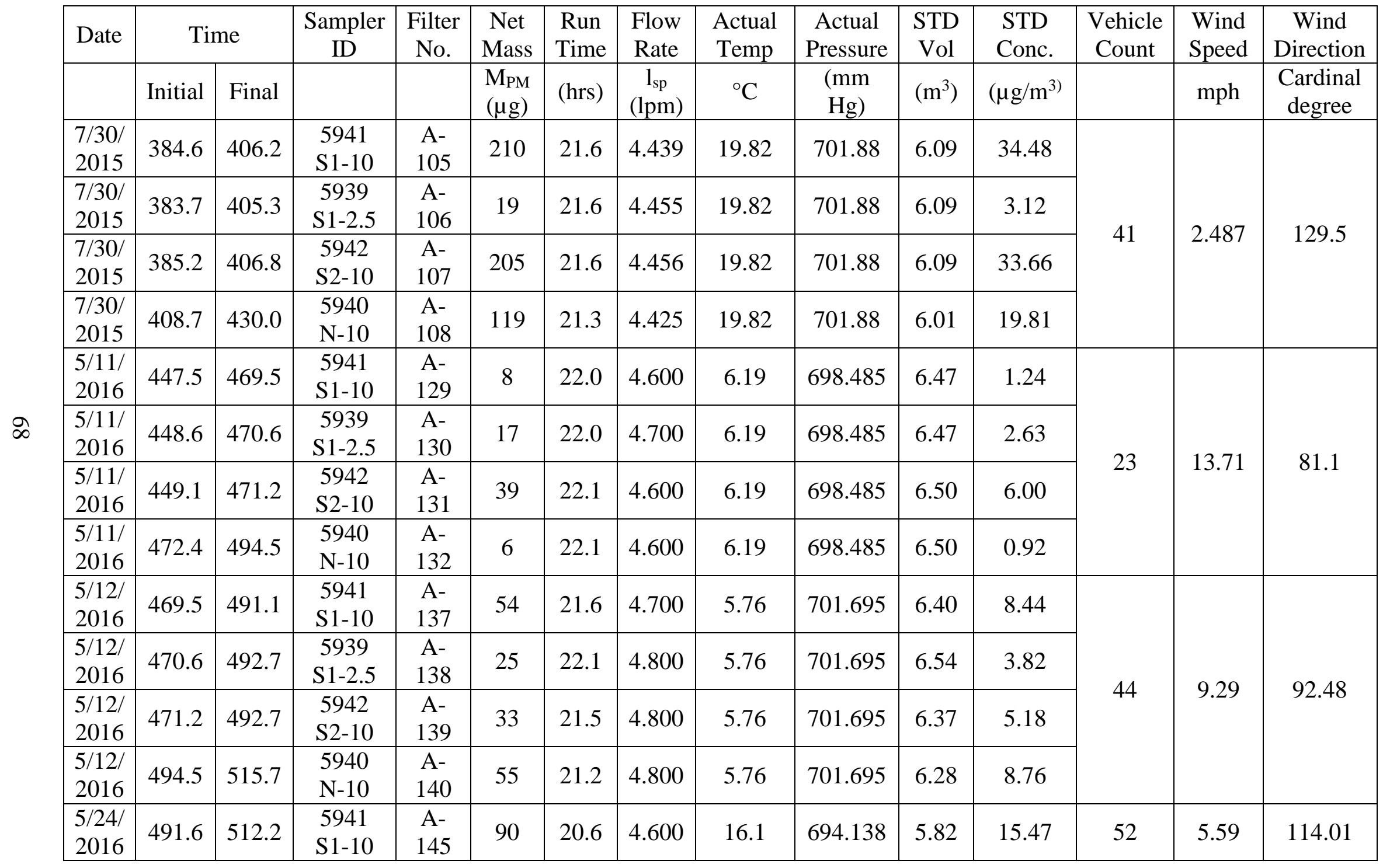


Table A2. Particulate matter concentration at site 1 (continued)

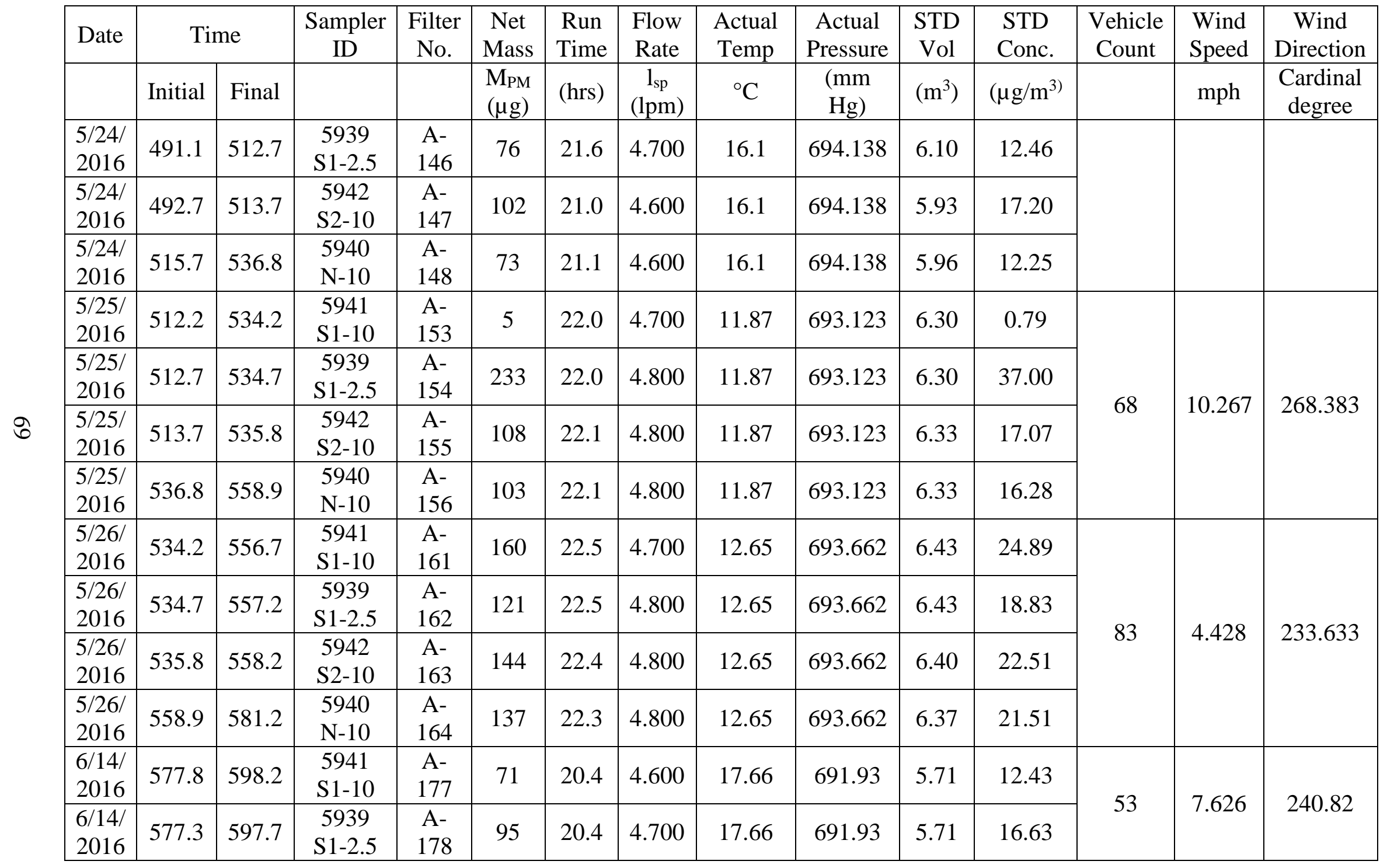


Table A2. Particulate matter concentration at site 1 (continued)

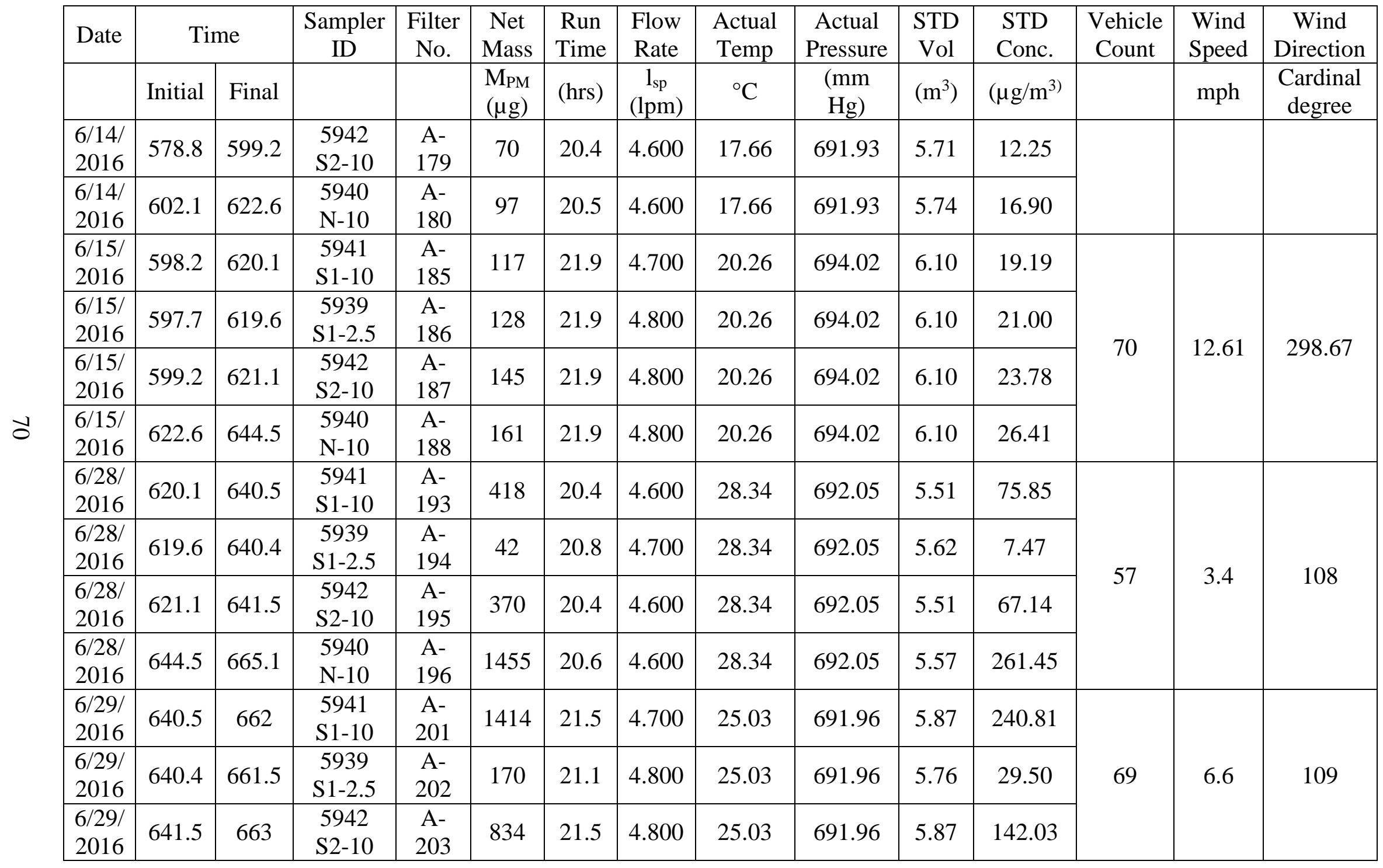


Table A2. Particulate matter concentration at site 1 (continued)

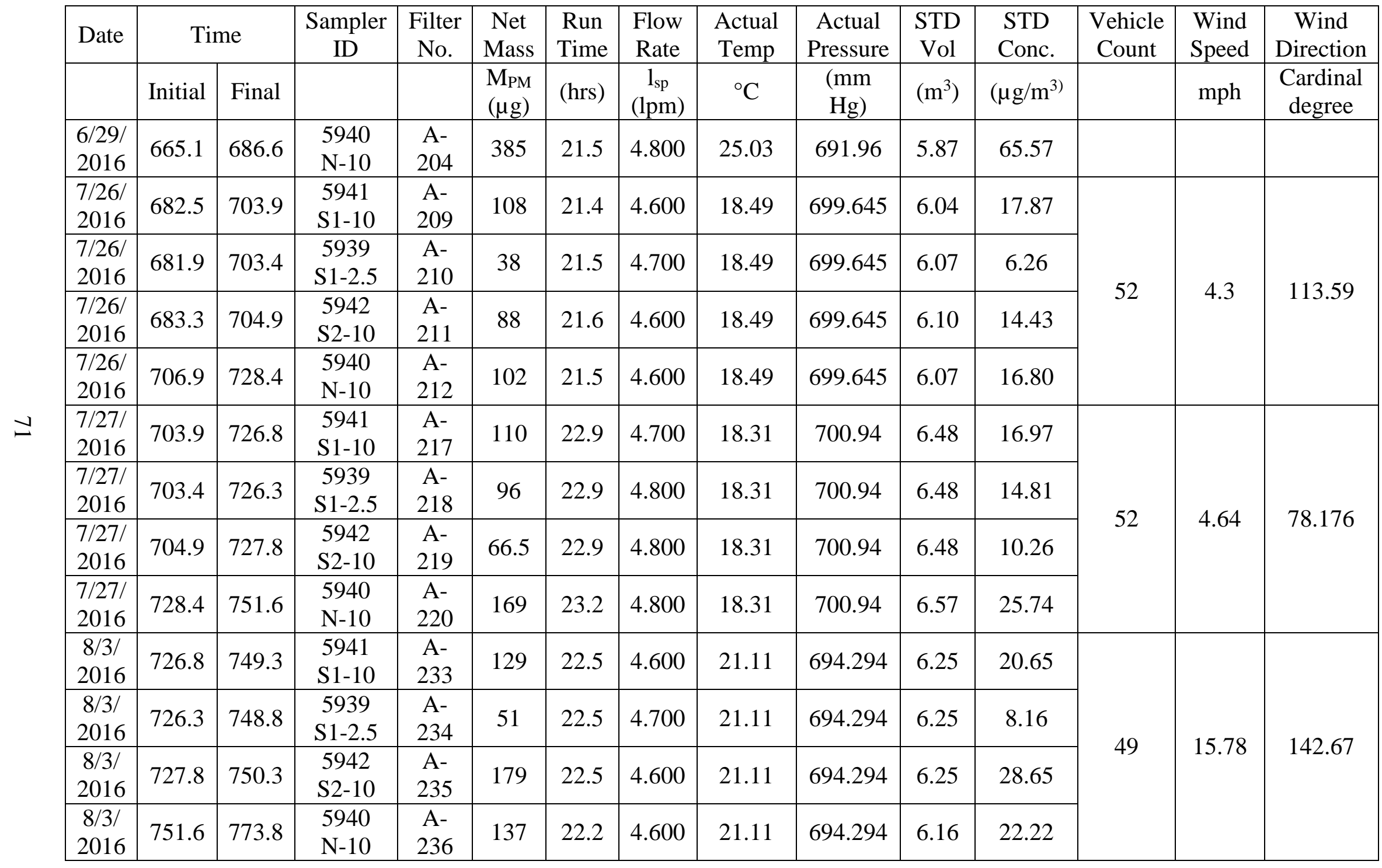


Table A2. Particulate matter concentration at site 1 (continued)

\begin{tabular}{|c|c|c|c|c|c|c|c|c|c|c|c|c|c|c|}
\hline \multirow[t]{2}{*}{ Date } & \multicolumn{2}{|c|}{ Time } & \multirow[t]{2}{*}{$\begin{array}{c}\text { Sampler } \\
\text { ID }\end{array}$} & \multirow[t]{2}{*}{$\begin{array}{c}\text { Filter } \\
\text { No. }\end{array}$} & \multirow{2}{*}{$\begin{array}{c}\text { Net } \\
\text { Mass } \\
\begin{array}{c}\text { MPM } \\
(\mu \mathrm{g})\end{array}\end{array}$} & \multirow{2}{*}{$\begin{array}{r}\text { Run } \\
\text { Time } \\
\text { (hrs) }\end{array}$} & \multirow{2}{*}{$\begin{array}{c}\begin{array}{c}\text { Flow } \\
\text { Rate }\end{array} \\
\begin{array}{c}1_{\mathrm{sp}} \\
(\mathrm{lpm})\end{array}\end{array}$} & \multirow{2}{*}{$\begin{array}{c}\begin{array}{c}\text { Actual } \\
\text { Temp }\end{array} \\
{ }^{\circ} \mathrm{C}\end{array}$} & \multirow{2}{*}{$\begin{array}{c}\begin{array}{c}\text { Actual } \\
\text { Pressure }\end{array} \\
(\mathrm{mm} \\
\mathrm{Hg})\end{array}$} & \multirow{2}{*}{$\begin{array}{l}\begin{array}{r}\text { STD } \\
\text { Vol }\end{array} \\
\left(\mathrm{m}^{3}\right)\end{array}$} & \multirow{2}{*}{$\begin{array}{c}\text { STD } \\
\text { Conc. }\end{array}$} & \multirow[t]{2}{*}{$\begin{array}{l}\text { Vehicle } \\
\text { Count }\end{array}$} & \multirow{2}{*}{$\begin{array}{c}\begin{array}{c}\text { Wind } \\
\text { Speed }\end{array} \\
\text { mph }\end{array}$} & \multirow{2}{*}{\begin{tabular}{|c|} 
Wind \\
Direction \\
$\begin{array}{c}\text { Cardinal } \\
\text { degree }\end{array}$
\end{tabular}} \\
\hline & Initial & Final & & & & & & & & & & & & \\
\hline $\begin{array}{c}8 / 4 / \\
2016\end{array}$ & 749.3 & 770.4 & $\begin{array}{c}5941 \\
S 1-10\end{array}$ & $\begin{array}{c}\text { A- } \\
241\end{array}$ & 112 & 21.1 & 4.700 & 17.14 & 699.27 & 5.98 & 18.72 & \multirow{4}{*}{68} & \multirow{4}{*}{7.77} & \multirow{4}{*}{138.4} \\
\hline $\begin{array}{c}8 / 4 / \\
2016\end{array}$ & 748.8 & 769.9 & $\begin{array}{c}5939 \\
S 1-2.5\end{array}$ & $\begin{array}{c}\text { A- } \\
242\end{array}$ & 34 & 21.1 & 4.800 & 17.14 & 699.27 & 5.98 & 5.68 & & & \\
\hline $\begin{array}{c}8 / 4 / \\
2016\end{array}$ & 750.3 & 771.4 & $\begin{array}{c}5942 \\
\text { S2-10 }\end{array}$ & $\begin{array}{c}\text { A- } \\
243\end{array}$ & 87 & 21.1 & 4.800 & 17.14 & 699.27 & 5.98 & 14.54 & & & \\
\hline $\begin{array}{c}8 / 4 / \\
2016\end{array}$ & 773.8 & 795.0 & $\begin{array}{l}5940 \\
\mathrm{~N}-10\end{array}$ & $\begin{array}{c}\text { A- } \\
244\end{array}$ & 85 & 21.2 & 4.800 & 17.14 & 699.27 & 6.01 & 14.14 & & & \\
\hline $\begin{array}{l}8 / 15 / \\
2016\end{array}$ & 770.4 & 791.4 & $\begin{array}{c}5941 \\
\text { S1-10 }\end{array}$ & $\begin{array}{c}\text { A- } \\
249\end{array}$ & 173 & 21.0 & 4.600 & 21.22 & 698.08 & 5.86 & 29.52 & \multirow{4}{*}{54} & \multirow{4}{*}{3.61} & \multirow{4}{*}{250.74} \\
\hline $\begin{array}{l}8 / 15 / \\
2016\end{array}$ & 769.9 & 790.9 & $\begin{array}{c}5939 \\
S 1-2.5\end{array}$ & $\begin{array}{c}\text { A- } \\
250\end{array}$ & 28 & 21.0 & 4.700 & 21.22 & 698.08 & 5.86 & 4.78 & & & \\
\hline $\begin{array}{l}8 / 15 / \\
2016\end{array}$ & 771.4 & 792.4 & $\begin{array}{c}5942 \\
\text { S2-10 }\end{array}$ & $\begin{array}{c}\text { A- } \\
251\end{array}$ & 114 & 21.0 & 4.600 & 21.22 & 698.08 & 5.86 & 19.45 & & & \\
\hline $\begin{array}{l}8 / 15 / \\
2016\end{array}$ & 795.0 & 816.1 & $\begin{array}{l}5940 \\
\mathrm{~N}-10\end{array}$ & $\begin{array}{c}\text { A- } \\
252\end{array}$ & 119 & 21.1 & 4.600 & 21.22 & 698.08 & 5.89 & 20.21 & & & \\
\hline $\begin{array}{l}8 / 16 / \\
2016\end{array}$ & 791.4 & 813.3 & $\begin{array}{c}5941 \\
\text { S1-10 }\end{array}$ & $\begin{array}{c}\text { A- } \\
257\end{array}$ & 287 & 21.9 & 4.700 & 22.97 & 699.007 & 6.08 & 47.17 & \multirow{4}{*}{56} & \multirow{4}{*}{3.77} & \multirow{4}{*}{205.15} \\
\hline $\begin{array}{l}8 / 16 / \\
2016\end{array}$ & 790.9 & 812.8 & $\begin{array}{c}5939 \\
S 1-2.5\end{array}$ & $\begin{array}{c}\text { A- } \\
258\end{array}$ & 75 & 21.9 & 4.800 & 22.97 & 699.007 & 6.08 & 12.33 & & & \\
\hline $\begin{array}{l}8 / 16 / \\
2016\end{array}$ & 792.4 & 814.3 & $\begin{array}{c}5942 \\
\text { S2-10 }\end{array}$ & $\begin{array}{c}\text { A- } \\
259\end{array}$ & 198 & 21.9 & 4.800 & 22.97 & 699.007 & 6.08 & 32.54 & & & \\
\hline $\begin{array}{l}8 / 16 / \\
2016\end{array}$ & 816.1 & 837.8 & $\begin{array}{l}5940 \\
\mathrm{~N}-10\end{array}$ & $\begin{array}{c}\text { A- } \\
260\end{array}$ & 198 & 21.7 & 4.800 & 22.97 & 699.007 & 6.03 & 32.84 & & & \\
\hline
\end{tabular}


A3. Particulate matter concentrations at site 2

S1-10 means sampler on the south side ( $\mathrm{N}$ means north) of the road about 100 feet from the center of the road with $\mathrm{PM}_{10}$ configuration. S2-10 means the sampler is 38 feet from the center of the road. S2-2.5 means a sampler with $\mathrm{PM}_{2.5}$ configuration.

Table A3

Particulate matter concentrations at site 2

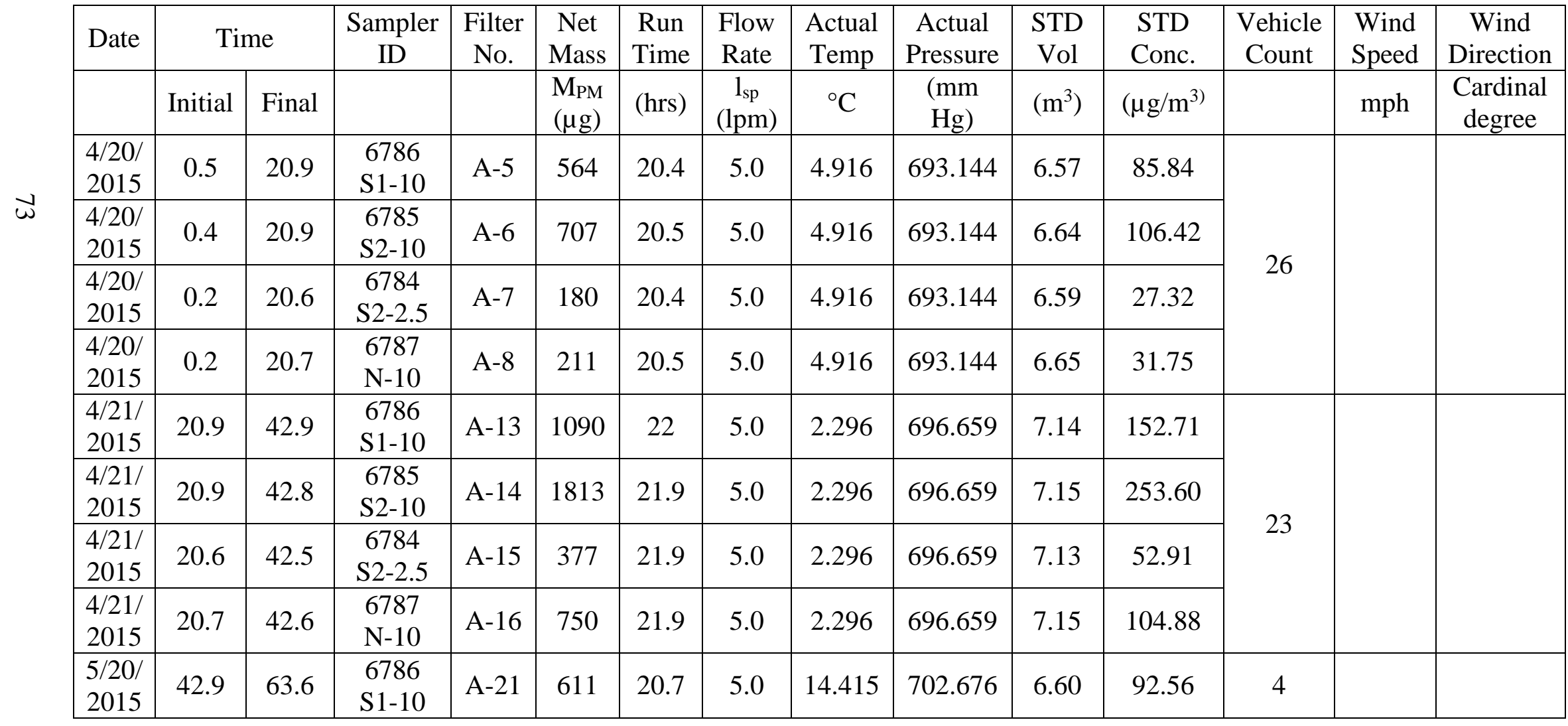


Table A3. Particulate matter concentrations at site 2 (continued)

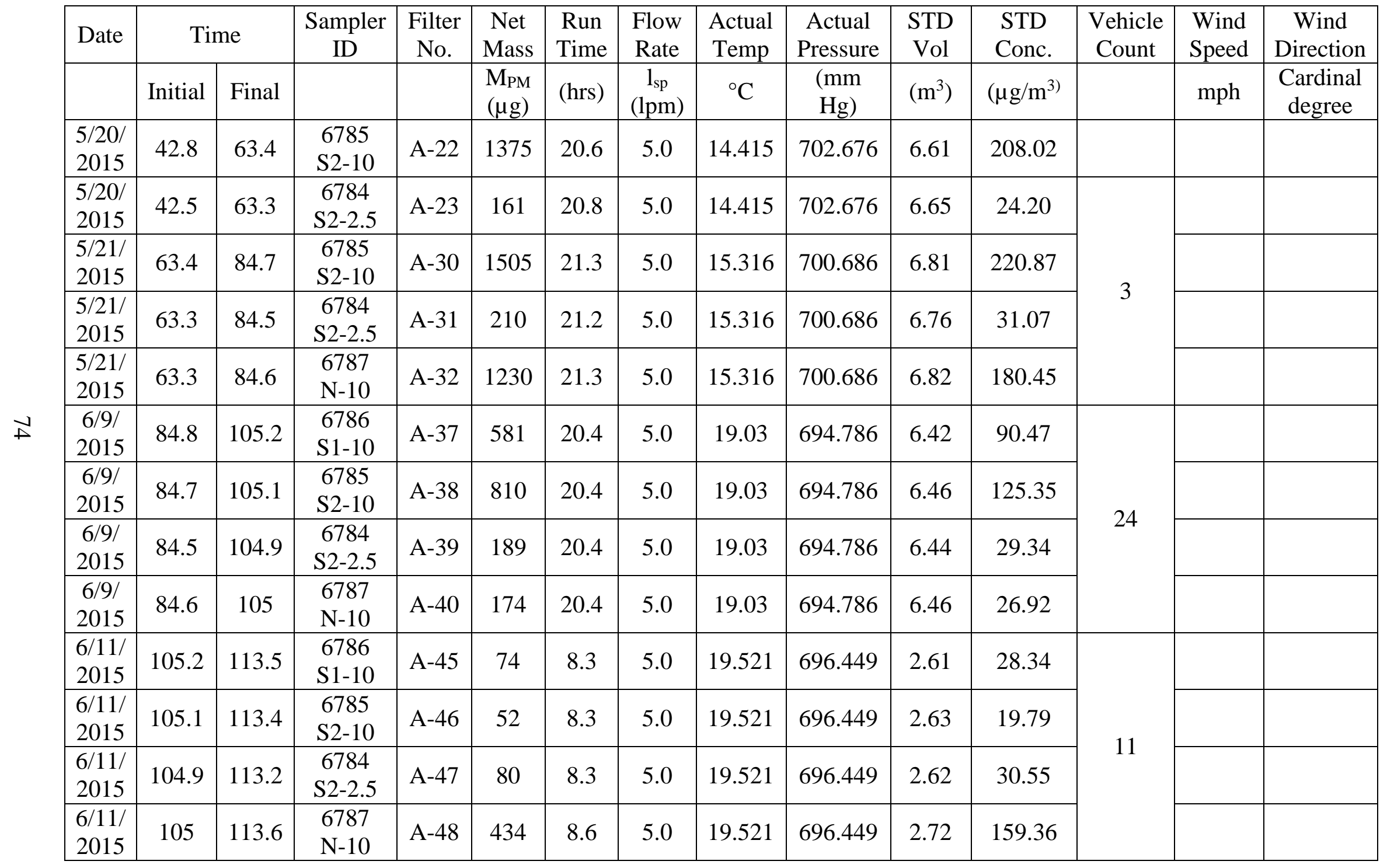


Table A3. Particulate matter concentrations at site 2 (continued)

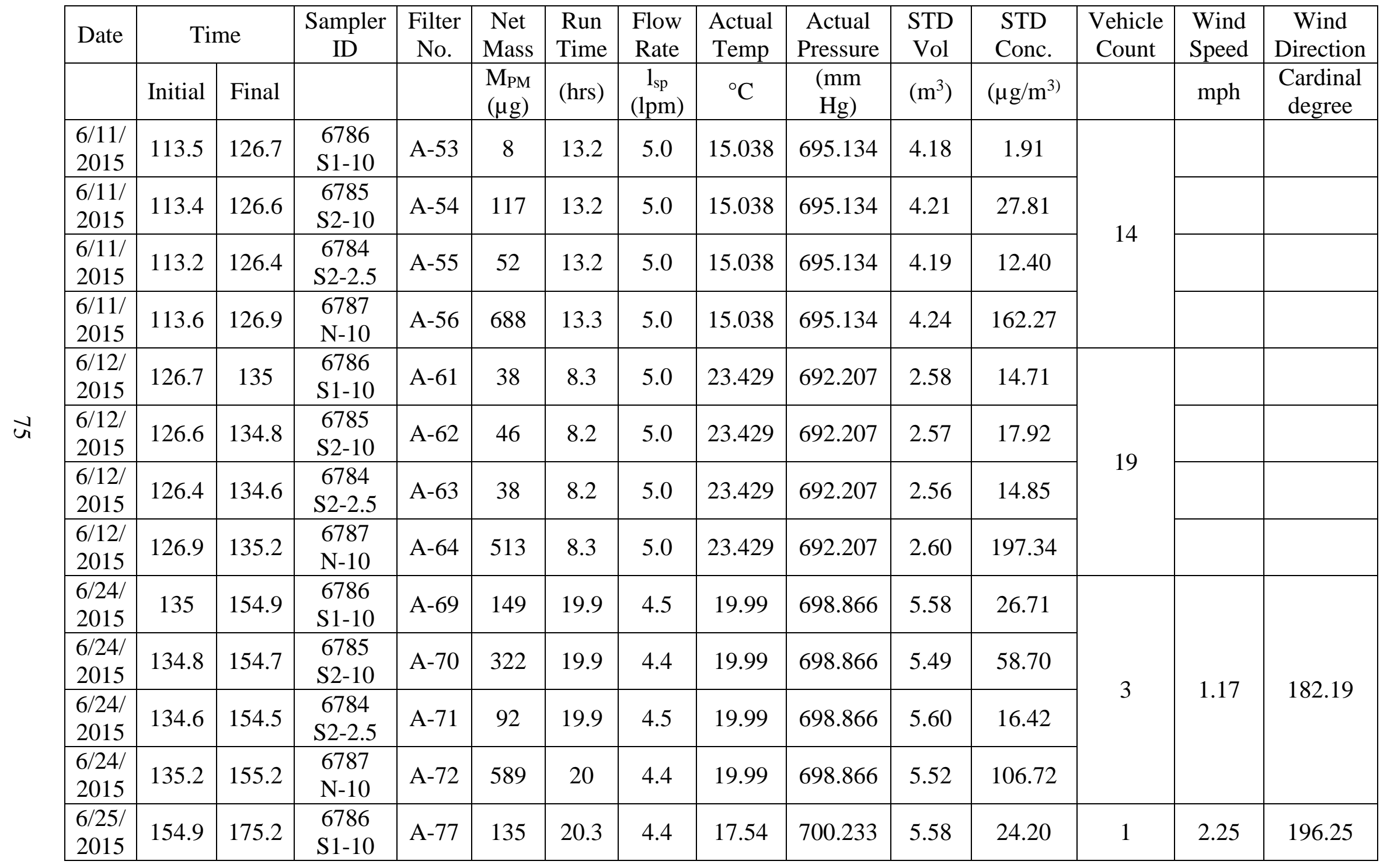


Table A3. Particulate matter concentrations at site 2 (continued)

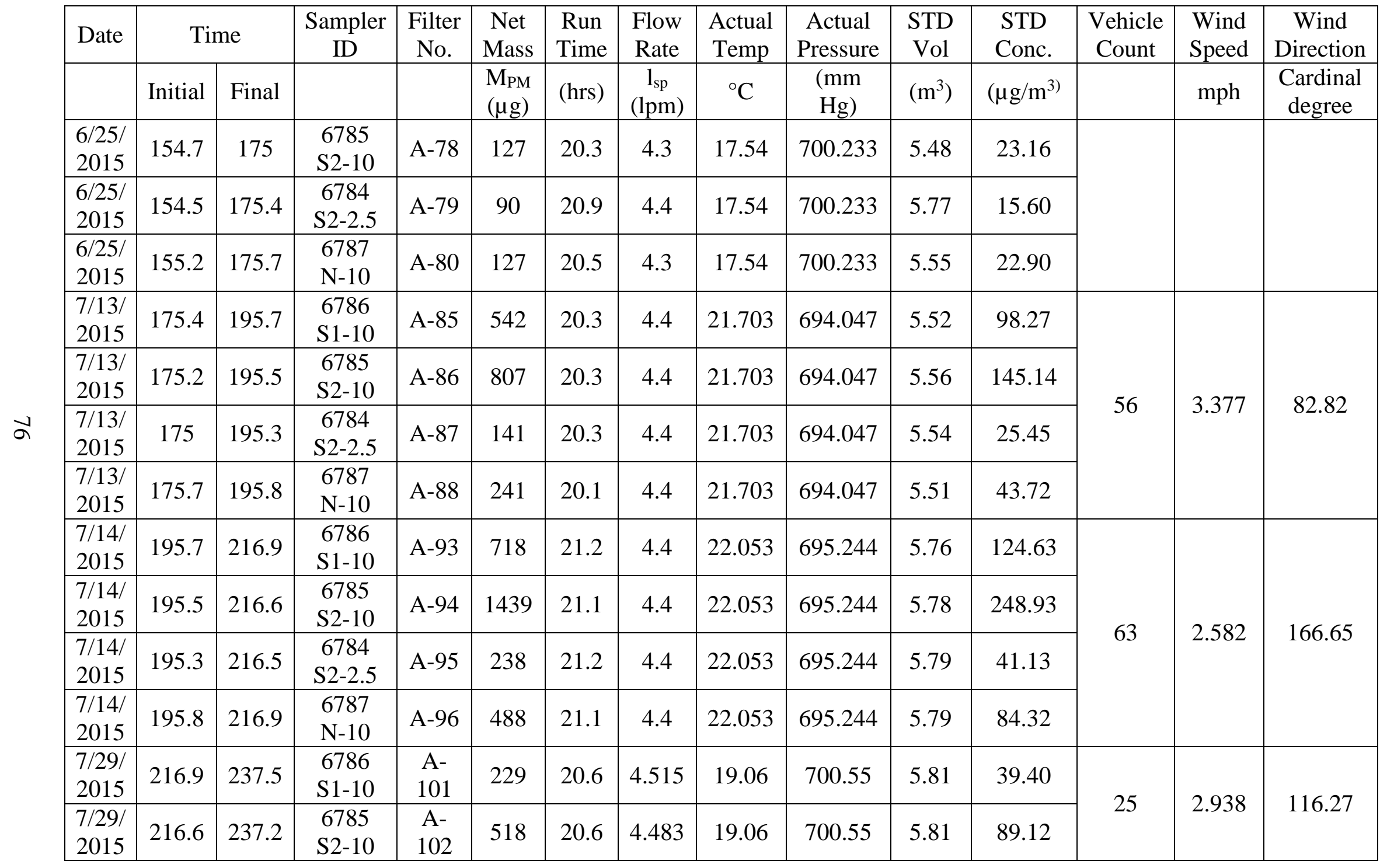


Table A3. Particulate matter concentrations at site 2 (continued)

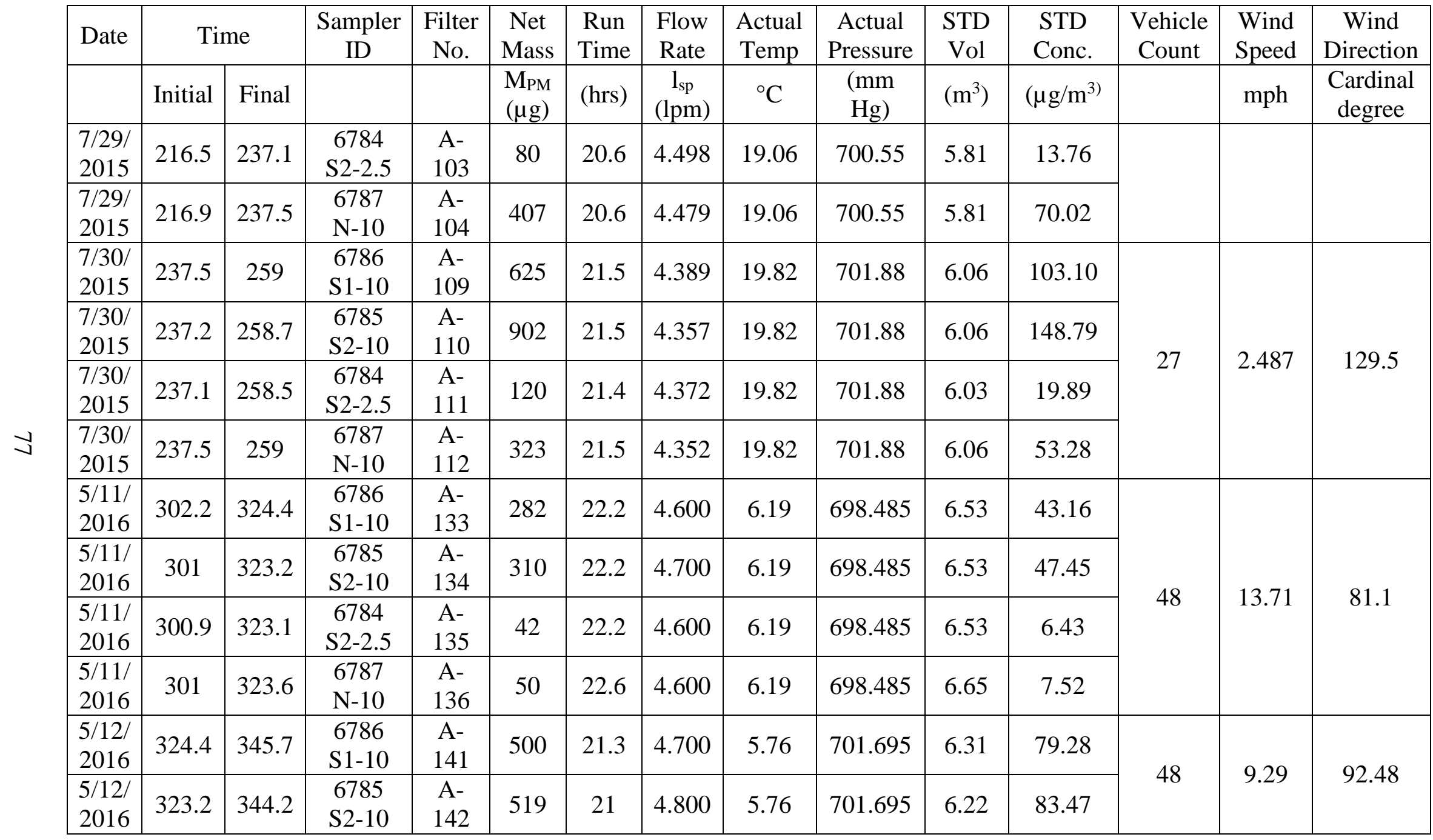


Table A3. Particulate matter concentrations at site 2 (continued)

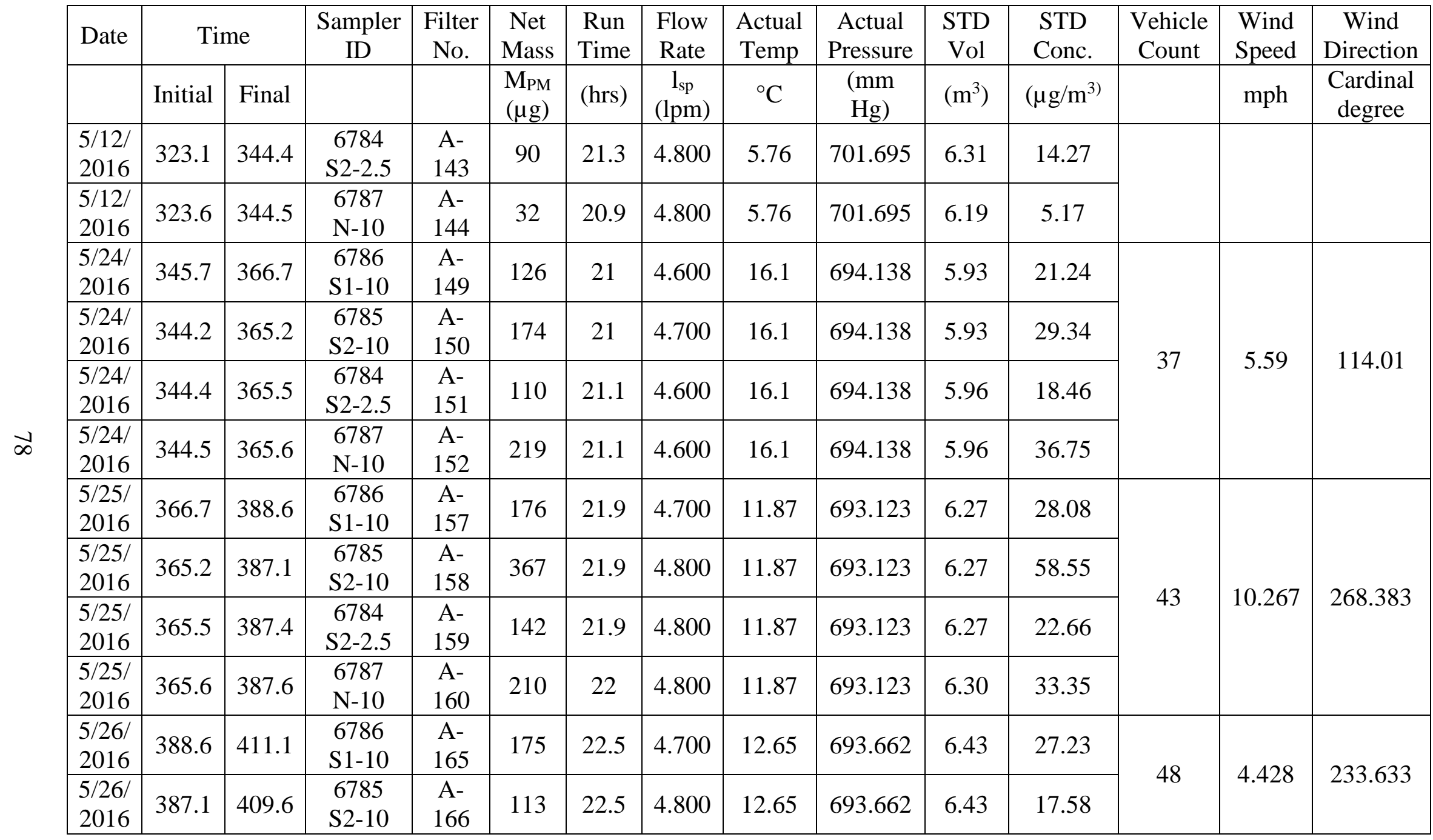


Table A3. Particulate matter concentrations at site 2 (continued)

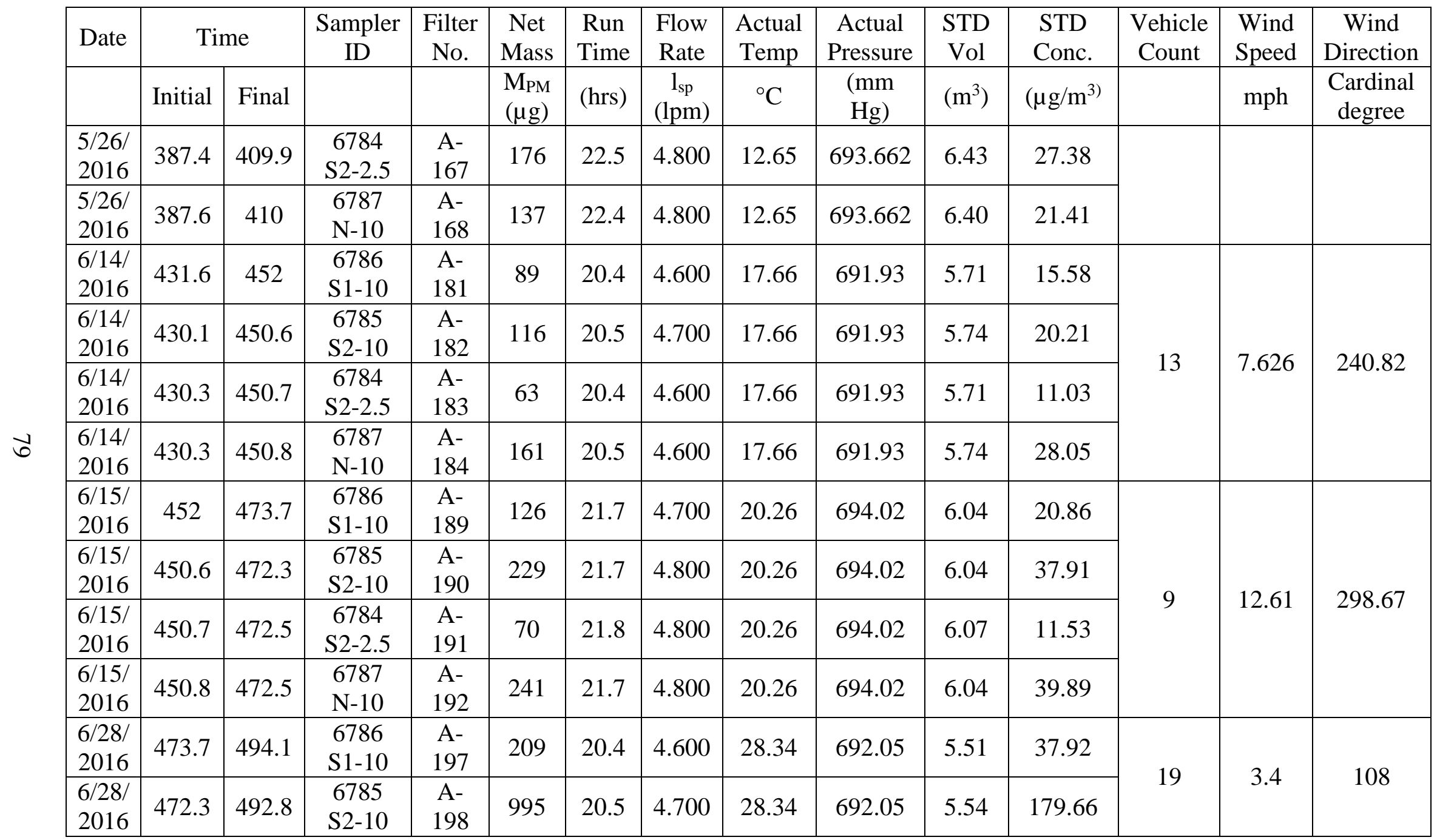


Table A3. Particulate matter concentrations at site 2 (continued)

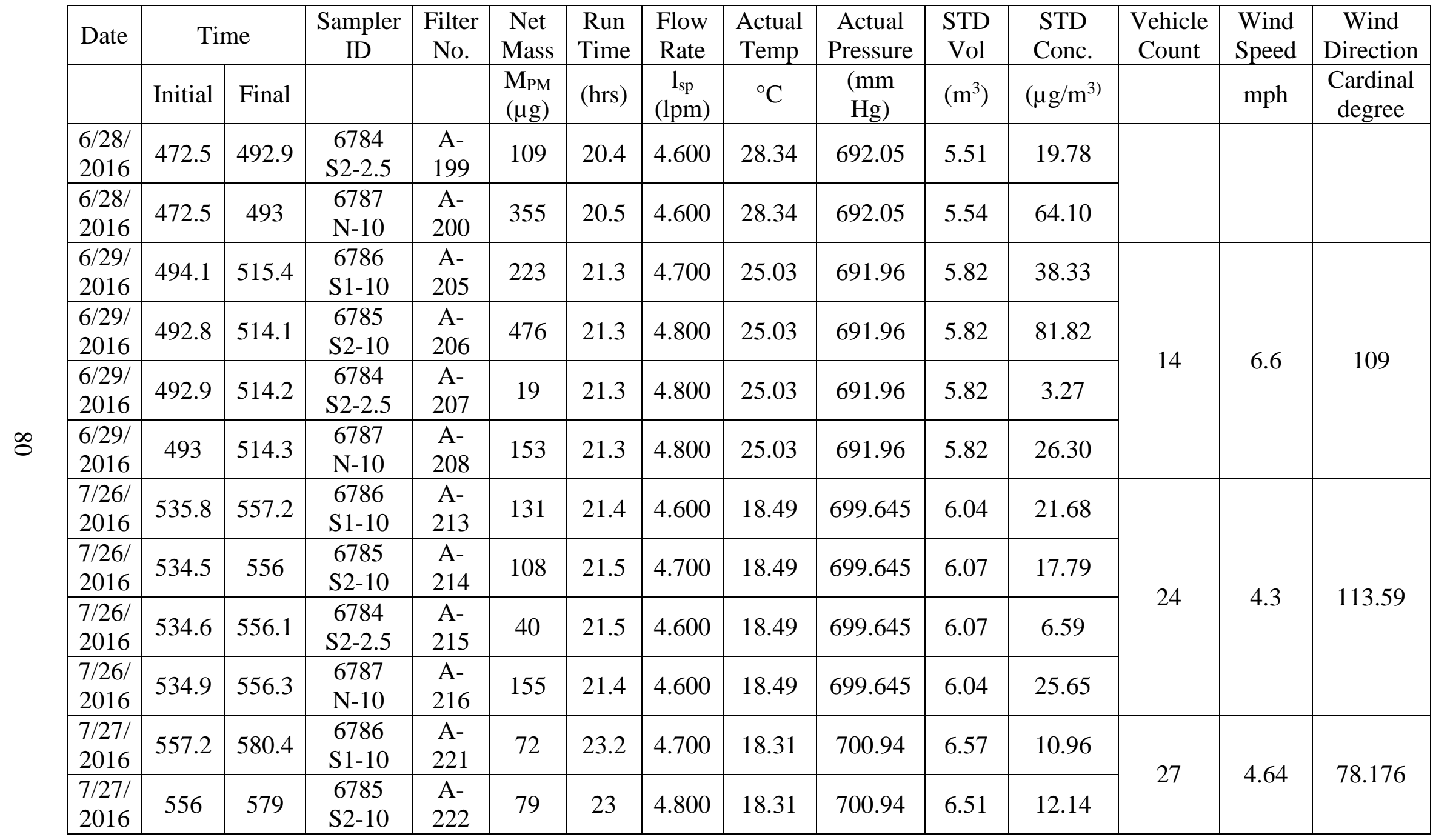


Table A3. Particulate matter concentrations at site 2 (continued)

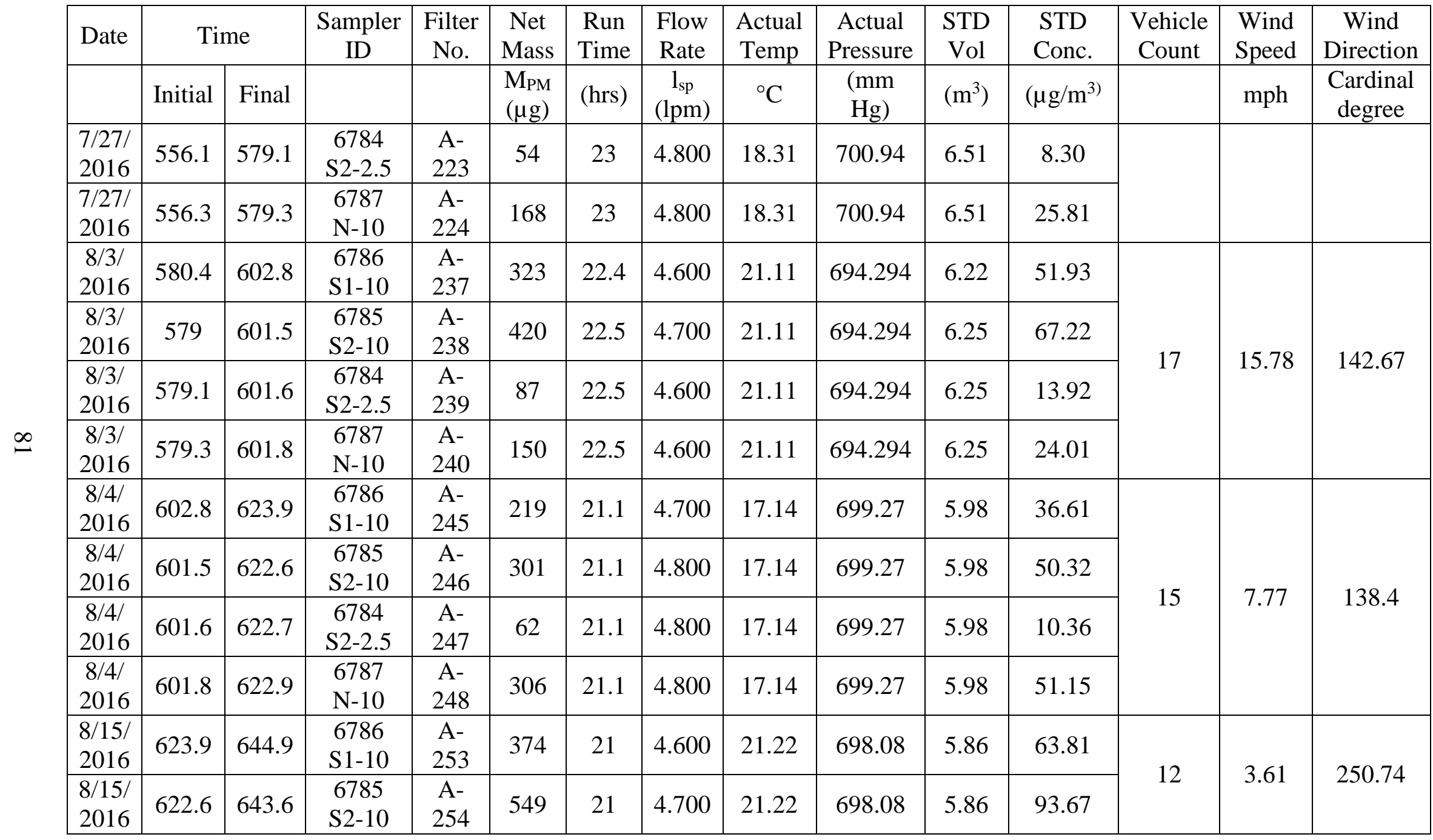


Table A3. Particulate matter concentrations at site 2 (continued)

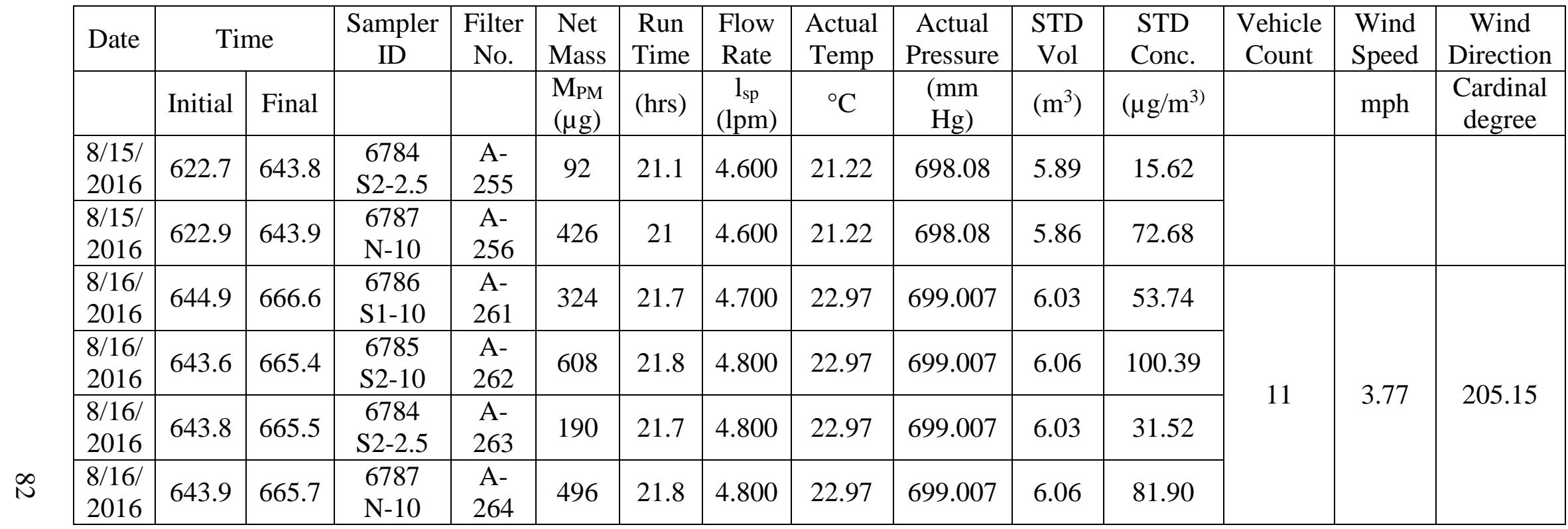

A4. Particulate matter concentrations at site 3

$\mathrm{C}$ is for control section, $\mathrm{N}$ and $\mathrm{S}$ indicate north and south side of the road, respectively. $\mathrm{B}$ means brine treated section and $\mathrm{M}$ is for magnesium chloride treated section. TSP is for total suspended particulates. 
Table A4.

Particulate matter concentrations at site 3

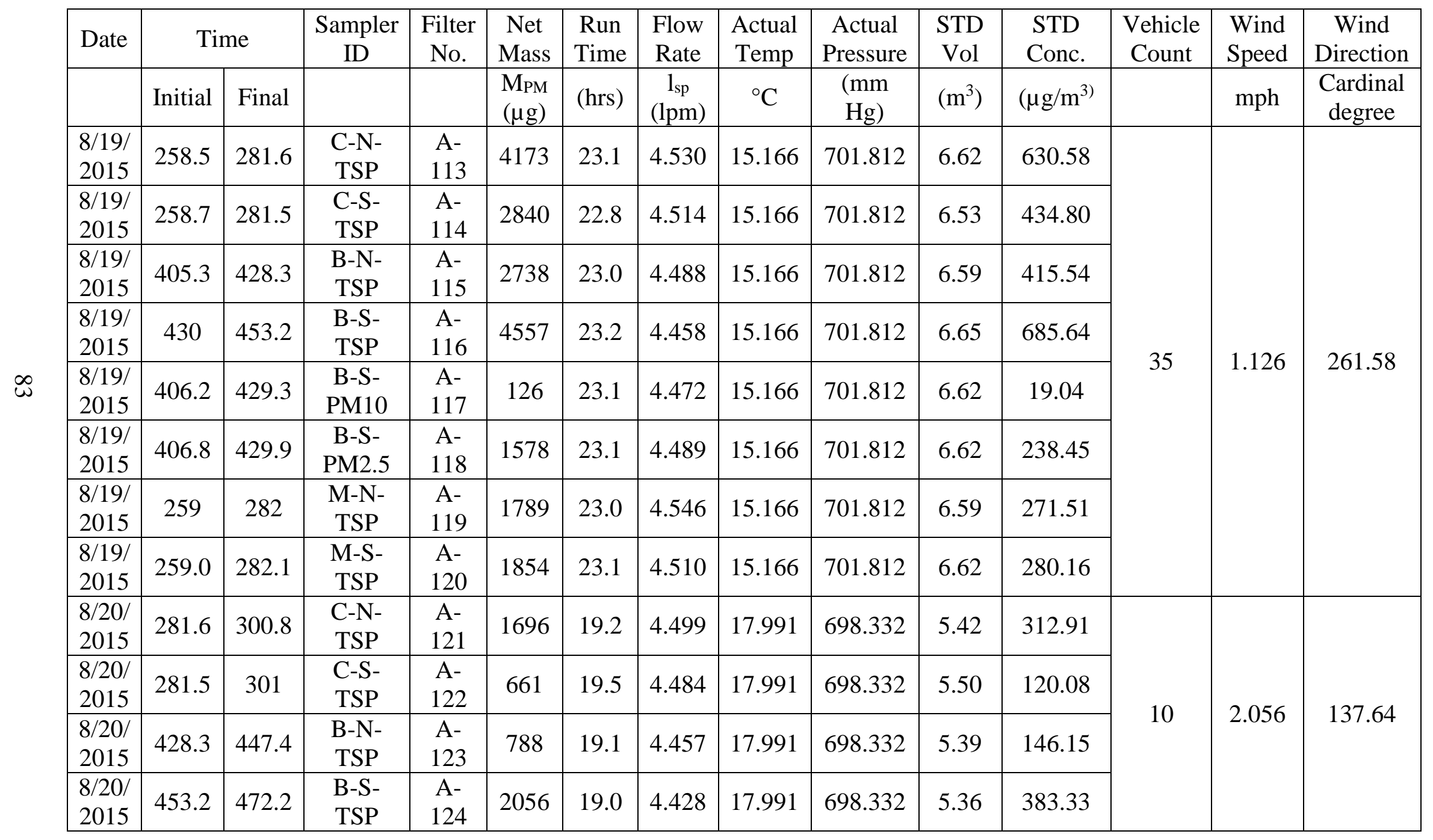


Table A4. Particulate matter concentrations at site 3 (continued)

\begin{tabular}{|c|c|c|c|c|c|c|c|c|c|c|c|c|c|c|}
\hline Date & \multicolumn{2}{|c|}{ Time } & $\begin{array}{l}\text { Sampler } \\
\text { ID }\end{array}$ & $\begin{array}{c}\text { Filter } \\
\text { No. }\end{array}$ & $\begin{array}{l}\text { Net } \\
\text { Mass }\end{array}$ & $\begin{array}{l}\text { Run } \\
\text { Time }\end{array}$ & $\begin{array}{l}\text { Flow } \\
\text { Rate }\end{array}$ & $\begin{array}{c}\text { Actual } \\
\text { Temp }\end{array}$ & $\begin{array}{c}\text { Actual } \\
\text { Pressure }\end{array}$ & $\begin{array}{l}\text { STD } \\
\text { Vol } \\
\end{array}$ & $\begin{array}{l}\text { STD } \\
\text { Conc. }\end{array}$ & $\begin{array}{l}\text { Vehicle } \\
\text { Count }\end{array}$ & $\begin{array}{l}\text { Wind } \\
\text { Speed }\end{array}$ & $\begin{array}{c}\text { Wind } \\
\text { Direction }\end{array}$ \\
\hline & Initial & Final & & & $\begin{array}{l}M_{P M} \\
(\mu g)\end{array}$ & (hrs) & $\begin{array}{c}1_{\mathrm{sp}} \\
(\mathrm{lpm})\end{array}$ & ${ }^{\circ} \mathrm{C}$ & $\begin{array}{c}(\mathrm{mm} \\
\mathrm{Hg})\end{array}$ & $\left(\mathrm{m}^{3}\right)$ & $\left(\mu \mathrm{g} / \mathrm{m}^{3}\right)$ & & mph & $\begin{array}{c}\text { Cardinal } \\
\text { degree }\end{array}$ \\
\hline $\begin{array}{l}8 / 20 / \\
2015\end{array}$ & 429.3 & 448.4 & $\begin{array}{l}\text { B-S- } \\
\text { PM10 }\end{array}$ & $\begin{array}{c}\text { A- } \\
125\end{array}$ & 124 & 19.1 & 4.441 & 17.991 & 698.332 & 5.39 & 23.00 & & & \\
\hline $\begin{array}{l}8 / 20 / \\
2015\end{array}$ & 429.9 & 449 & $\begin{array}{c}\text { B-S- } \\
\text { PM2.5 }\end{array}$ & $\begin{array}{l}\text { A- } \\
126\end{array}$ & 272 & 19.1 & 4.458 & 17.991 & 698.332 & 5.39 & 50.45 & & & \\
\hline $\begin{array}{l}8 / 20 / \\
2015\end{array}$ & 282 & 300.1 & $\begin{array}{l}\text { M-N- } \\
\text { TSP }\end{array}$ & $\begin{array}{l}\text { A- } \\
127\end{array}$ & 801 & 18.1 & 4.516 & 17.991 & 698.332 & 5.11 & 156.77 & & & \\
\hline $\begin{array}{l}8 / 20 / \\
2015 \\
\end{array}$ & 282.1 & 300.9 & $\begin{array}{c}\text { M-S- } \\
\text { TSP }\end{array}$ & $\begin{array}{c}\text { A- } \\
128 \\
\end{array}$ & 506 & 18.8 & 4.480 & 17.991 & 698.332 & 5.31 & 95.34 & & & \\
\hline
\end{tabular}




\section{APPENDIX B}

Table B1

Identification of filters with respect to their locations and sampling date

\begin{tabular}{|c|c|c|}
\hline Filter No. & Site number & Sampling date \\
\hline $\mathrm{A}-9$ & 1 & $04 / 21 / 2015$ \\
\hline $\mathrm{A}-10$ & 1 & $04 / 21 / 2015$ \\
\hline $\mathrm{A}-14$ & 2 & $04 / 21 / 2016$ \\
\hline $\mathrm{A}-15$ & 2 & $04 / 21 / 2015$ \\
\hline $\mathrm{A}-25$ & 1 & $05 / 21 / 2015$ \\
\hline $\mathrm{A}-27$ & 1 & $05 / 21 / 2015$ \\
\hline $\mathrm{A}-30$ & 2 & $05 / 21 / 2015$ \\
\hline $\mathrm{A}-31$ & 2 & $05 / 21 / 2015$ \\
\hline $\mathrm{A}-64$ & 2 & $06 / 12 / 2015$ \\
\hline $\mathrm{A}-94$ & 2 & $7 / 14 / 2015$ \\
\hline $\mathrm{A}-120$ & 3 & $8 / 20 / 2015$ \\
\hline $\mathrm{A}-129$ & 1 & $05 / 11 / 2016$ \\
\hline $\mathrm{A}-150$ & 2 & $5 / 24 / 2016$ \\
\hline
\end{tabular}

Table B2

Relative weight percentages of corresponding elements resulting from EDS analysis

\begin{tabular}{|c|c|c|c|c|c|c|c|c|c|c|c|c|}
\hline $\begin{array}{c}\text { SEM } \\
\text { sample ID }\end{array}$ & $\mathrm{O}$ & $\mathrm{Na}$ & $\mathrm{Mg}$ & $\mathrm{Al}$ & $\mathrm{Si}$ & $\mathrm{P}$ & $\mathrm{S}$ & $\mathrm{Cl}$ & $\mathrm{K}$ & $\mathrm{Ca}$ & $\mathrm{Mn}$ & $\mathrm{Fe}$ \\
\hline 158426-A9(1)_pt1 & 49.0 & 5.8 & & 8.86 & 33.34 & & & & & 2.9 & & \\
\hline 158426-A9(1)_pt2 & 47.9 & 0.8 & 1.49 & 6.61 & 31.52 & 0.22 & & & 0.2 & 5.1 & & 5.9 \\
\hline 158426-A9(1)_pt3 & 37.1 & 0.3 & 0.74 & 2.66 & 13.46 & 0.32 & & 0.31 & 0.4 & 0.6 & 1.7 & 42.0 \\
\hline 158426-A9(1)_pt4 & 47.5 & 1.1 & 0.61 & 15.63 & 26.55 & & 0.7 & & 3.0 & 1.4 & & 3.3 \\
\hline 158426-A9(2)_pt1 & 46.9 & 0.9 & 1.33 & 6.21 & 30.12 & & & & 0.8 & 3.1 & & 10.4 \\
\hline 158426-A9(2)_pt2 & 50.1 & 2.4 & 0.04 & 6.83 & 36.67 & & & & 0.6 & 2.3 & & 0.8 \\
\hline 158426-A9(2)_pt3 & 53.2 & & & 0.03 & 46.71 & & & & & & & \\
\hline 158426-A9(2)_pt4 & 47.1 & 2.0 & 0.35 & 8.61 & 31.47 & & & & 7.4 & 1.1 & & 1.7 \\
\hline
\end{tabular}


Table B2. Relative weight percentages of corresponding elements resulting from EDS analysis (continued)

\begin{tabular}{|c|c|c|c|c|c|c|c|c|c|c|c|c|c|}
\hline SEM sample ID & $\mathrm{O}$ & $\mathrm{Na}$ & $\mathrm{Mg}$ & $\mathrm{Al}$ & $\mathrm{Si}$ & $\mathrm{P}$ & $S$ & $\mathrm{Cl}$ & $\mathrm{K}$ & $\mathrm{Ca}$ & $\mathrm{Ti}$ & $\mathrm{Mn}$ & $\mathrm{Fe}$ \\
\hline 158426-A9(3)_pt1 & 53.12 & 0.37 & & & 46.51 & & & & & & & & \\
\hline 158426-A9(3)_pt2 & 46.99 & 1.57 & 1.63 & 6.36 & 31.01 & & 1.00 & 0.41 & 1.08 & 3.66 & & & 6.29 \\
\hline 158426-A9(3)_pt3 & 52.22 & 0.91 & 0.36 & 1.58 & 43.86 & & & & 0.71 & 0.37 & & & \\
\hline 158426-A9(4)_pt1 & 50.50 & 1.97 & & 0.59 & 41.07 & & & & & 5.30 & 0.57 & & \\
\hline 158426-A9(4)_pt2 & 51.23 & 1.12 & 0.46 & 2.81 & 41.05 & & & & 0.59 & 1.13 & & & 1.62 \\
\hline 158426-A9(4)_pt3 & 53.12 & 0.37 & & & 46.51 & & & & & & & & \\
\hline 158426-A9(5)_pt1 & 28.75 & 39.05 & & & 2.43 & & 6.16 & 10.46 & 10.65 & 2.52 & & & \\
\hline 158426-A9(5)_pt2 & 27.44 & 24.85 & & 0.83 & 5.01 & & 6.19 & 23.17 & 9.83 & 2.66 & & & \\
\hline 158426-A9(5)_pt3 & 32.44 & 31.04 & 0.86 & & 9.43 & & 4.98 & 9.43 & 9.46 & 2.35 & & & \\
\hline 158426-A9(5)_pt4 & 31.69 & 17.09 & & 0.34 & 17.51 & & 1.37 & 15.24 & 16.76 & & & & \\
\hline 158426-A9(6)_pt1 & 53.26 & & & & 46.74 & & & & & & & & \\
\hline 158426-A9(6)_pt2 & 51.79 & 0.53 & 0.54 & 0.17 & 40.29 & 1.03 & 1.82 & & 2.00 & 1.83 & & & \\
\hline 158426-A9(6)_pt3 & 50.79 & 1.06 & 0.64 & 4.46 & 39.30 & & & & 1.49 & 0.54 & & & 1.73 \\
\hline 158426-A9(6)_pt4 & 49.45 & 0.89 & 0.45 & 13.13 & 30.97 & & & & 1.36 & 0.62 & & & 3.13 \\
\hline 158426-A9(7)_pt1 & 47.87 & 0.83 & 1.18 & 11.64 & 29.12 & & & & 3.17 & 0.85 & & & 5.34 \\
\hline 158426-A9(7)_pt2 & 50.24 & 1.09 & 0.86 & 4.66 & 38.17 & & & & 1.98 & 1.18 & & & 1.82 \\
\hline 158426-A9(8)_pt1 & 45.77 & 0.57 & 2.11 & 6.39 & 27.71 & & 0.31 & 0.55 & 2.30 & 5.20 & & & 9.09 \\
\hline 158426-A9(8)_pt2 & 51.00 & 0.92 & 0.67 & 2.99 & 40.43 & & & & 0.76 & 0.86 & & & 2.36 \\
\hline 158426-A9(8)_pt3 & 53.06 & 0.54 & & & 46.40 & & & & & & & & \\
\hline 158426-A9(8)_pt4 & 52.50 & 0.50 & 0.11 & & 45.55 & & & & 0.86 & 0.48 & & & \\
\hline 158426-A9(8)_pt5 & 48.79 & 0.81 & 1.31 & 10.89 & 30.50 & & 0.22 & & 2.01 & 0.91 & 0.64 & & 3.92 \\
\hline 158426-A9(9)_pt1 & 45.08 & 0.75 & 1.44 & 2.94 & 27.02 & 0.65 & 0.48 & & 0.48 & 4.95 & & 0.87 & 15.34 \\
\hline 158426-A9(9)_pt2 & 43.58 & & 1.55 & 7.36 & 22.48 & & & 0.32 & 0.79 & 1.47 & & & 22.45 \\
\hline 158426-A9(9)_pt3 & 47.72 & & & 0.14 & 3.24 & & 22.21 & & & 26.69 & & & \\
\hline 158426-A9(9)_pt4 & 53.24 & & & 0.12 & 46.64 & & & & & & & & \\
\hline 158426-A9(9)_pt5 & 53.26 & & & & 46.74 & & & & & & & & \\
\hline
\end{tabular}


Table B2. Relative weight percentages of corresponding elements resulting from EDS analysis (continued)

\begin{tabular}{|c|c|c|c|c|c|c|c|c|c|c|c|c|c|c|c|}
\hline SEM sample ID & $\mathrm{N}$ & $\mathrm{C}$ & $\mathrm{O}$ & $\mathrm{Na}$ & $\mathrm{Mg}$ & $\mathrm{Al}$ & $\mathrm{Si}$ & $\mathrm{P}$ & $\mathrm{S}$ & $\mathrm{Cl}$ & $\mathrm{K}$ & $\mathrm{Ca}$ & $\mathrm{Ti}$ & $\mathrm{Mn}$ & $\mathrm{Fe}$ \\
\hline $\begin{array}{l}\text { 158426- } \\
\text { A9(10)_pt1 }\end{array}$ & & & 53.02 & 0.48 & & 0.48 & 46.02 & & & & & & & & \\
\hline $\begin{array}{l}\text { 158426- } \\
\text { A9(10)_pt2 }\end{array}$ & & & 52.68 & 1.37 & & & 45.00 & 0.68 & & & 0.26 & & & & \\
\hline $\begin{array}{l}\text { 158426- } \\
\text { A9(10)_pt3 }\end{array}$ & & & 52.49 & 0.61 & 0.42 & 2.07 & 43.94 & & & & 0.47 & & & & \\
\hline $\begin{array}{l}\text { 158426- } \\
\text { A9(11)_pt1 }\end{array}$ & & & 36.08 & & 0.67 & 2.10 & 10.86 & & & 0.32 & 0.26 & 0.46 & & & 49.25 \\
\hline $\begin{array}{l}\text { 158426- } \\
\text { A9(11)_pt2 }\end{array}$ & & & 53.26 & & & & 46.74 & & & & & & & & \\
\hline $\begin{array}{l}\text { 158426- } \\
\text { A9(11)_pt3 }\end{array}$ & & & 49.43 & 1.01 & 0.64 & 7.26 & 35.10 & & & & 2.63 & 0.70 & & & 3.24 \\
\hline $\begin{array}{l}\text { 158426- } \\
\text { A9(11)_pt4 }\end{array}$ & & & 53.26 & & & & 46.74 & & & & & & & & \\
\hline $\begin{array}{l}\text { 158426- } \\
\text { A9(11)_pt5 }\end{array}$ & & & 53.26 & & & & 46.74 & & & & & & & & \\
\hline $\begin{array}{l}\text { 158426- } \\
\text { A9(2ndDay)(1)_p } \\
\text { t1 }\end{array}$ & 3.71 & & 55.71 & 0.66 & & 0.07 & 38.79 & & 0.35 & 0.41 & & 0.30 & & & \\
\hline $\begin{array}{l}\text { 158426- } \\
\text { A9(2ndDay)(1)_p } \\
\text { t2 }\end{array}$ & & & 47.30 & 0.37 & 2.89 & 9.20 & 29.73 & & & 0.49 & 4.87 & & & & 5.16 \\
\hline $\begin{array}{l}\text { 158426- } \\
\text { A9(2ndDay)(2)_p } \\
\text { t1 }\end{array}$ & & & 50.32 & 0.94 & 0.47 & 5.56 & 37.70 & & & & 1.59 & 0.40 & & & 3.01 \\
\hline
\end{tabular}


Table B2. Relative weight percentages of corresponding elements resulting from EDS analysis (continued)

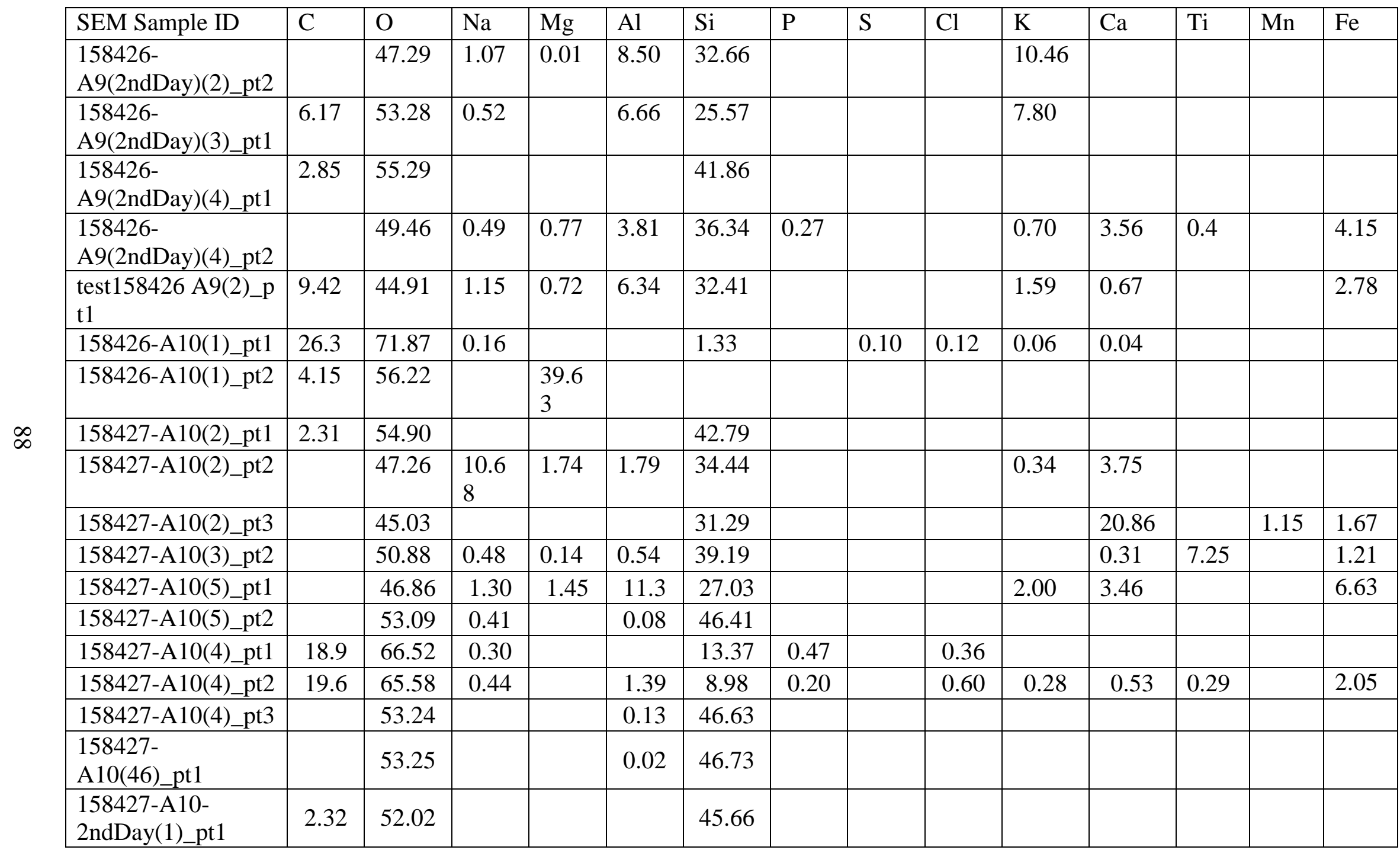


Table B2. Relative weight percentages of corresponding elements resulting from EDS analysis (continued)

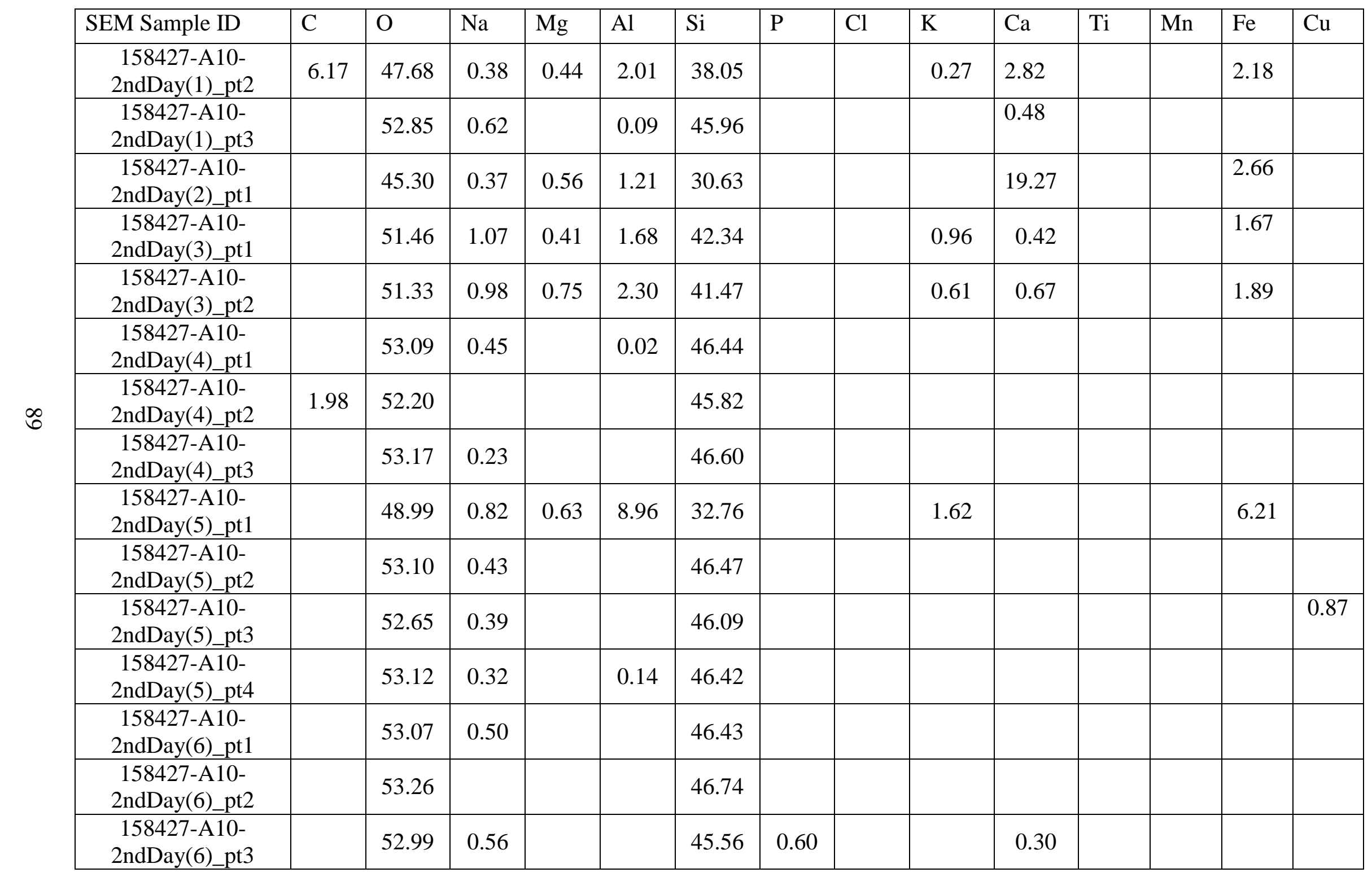


Table B2. Relative weight percentages of corresponding elements resulting from EDS analysis (continued)

\begin{tabular}{|c|c|c|c|c|c|c|c|c|c|c|c|c|c|}
\hline SEM Sample ID & $\mathrm{C}$ & $\mathrm{O}$ & $\mathrm{Na}$ & $\mathrm{Mg}$ & $\mathrm{Al}$ & $\mathrm{Si}$ & $\mathrm{P}$ & $\mathrm{Cl}$ & $\mathrm{K}$ & $\mathrm{Ca}$ & $\mathrm{Ti}$ & $\mathrm{Mn}$ & $\mathrm{Fe}$ \\
\hline $\begin{array}{c}\text { 158427-A10- } \\
\text { 2ndDay(7)_pt1 }\end{array}$ & & 49.96 & 0.83 & 0.82 & 3.52 & 37.97 & & & 0.68 & 2.63 & & & 3.60 \\
\hline $\begin{array}{c}\text { 158427-A10- } \\
\text { 2ndDay(7)_pt2 }\end{array}$ & & 47.41 & 0.92 & 2.27 & 12.02 & 27.45 & & & 3.09 & 0.94 & 0.36 & & 5.55 \\
\hline $\begin{array}{c}\text { 158427-A10- } \\
\text { 2ndDay(7)_pt3 }\end{array}$ & & 45.25 & 0.23 & 7.18 & 15.02 & 18.66 & & & 0.89 & 0.35 & 0.69 & & 11.72 \\
\hline $\begin{array}{c}\text { 158427-A10- } \\
\text { 2ndDay(7)_pt4 }\end{array}$ & & 42.57 & 2.20 & 1.19 & 5.03 & 22.30 & & & 0.36 & 18.40 & 1.25 & & 6.70 \\
\hline $\begin{array}{l}\text { 158427-A10- } \\
\text { 2ndDay(7)_pt6 }\end{array}$ & & 52.00 & 0.52 & 0.35 & 2.10 & 42.93 & & & 0.31 & 0.58 & & & 1.19 \\
\hline $\begin{array}{l}\text { 158427-A10- } \\
\text { 2ndDay(7)_pt7 }\end{array}$ & & 50.79 & 0.31 & 0.20 & 1.13 & 41.40 & & & 1.05 & 1.06 & & & 4.05 \\
\hline $\begin{array}{c}\text { 158427-A10- } \\
\text { 2ndDay(7)_pt10 }\end{array}$ & & 41.30 & & 0.52 & 1.09 & 23.20 & & & & 32.87 & & & 1.03 \\
\hline 158427-A14(1)_pt1 & & 49.02 & 1.16 & 0.85 & 8.34 & 33.17 & & & 1.71 & 1.91 & 0.36 & & 3.46 \\
\hline 158427-A14(2)_pt1 & 95.66 & 2.30 & & & 0.13 & 1.92 & & & & & & & \\
\hline 158427-A14(2)_pt2 & 6.31 & 40.92 & 0.62 & 5.08 & 11.28 & 17.12 & & & 0.82 & 0.43 & & & 17.42 \\
\hline 158427-A14(2)_pt3 & & 47.98 & 1.01 & 0.58 & 14.72 & 28.16 & & & 5.11 & 0.82 & & & 1.62 \\
\hline 158427-A14(3)_pt1 & & 47.97 & 0.97 & 1.70 & 10.97 & 29.37 & & & 2.42 & 1.03 & & & 5.56 \\
\hline
\end{tabular}


Table B2. Relative weight percentages of corresponding elements resulting from EDS analysis (continued)

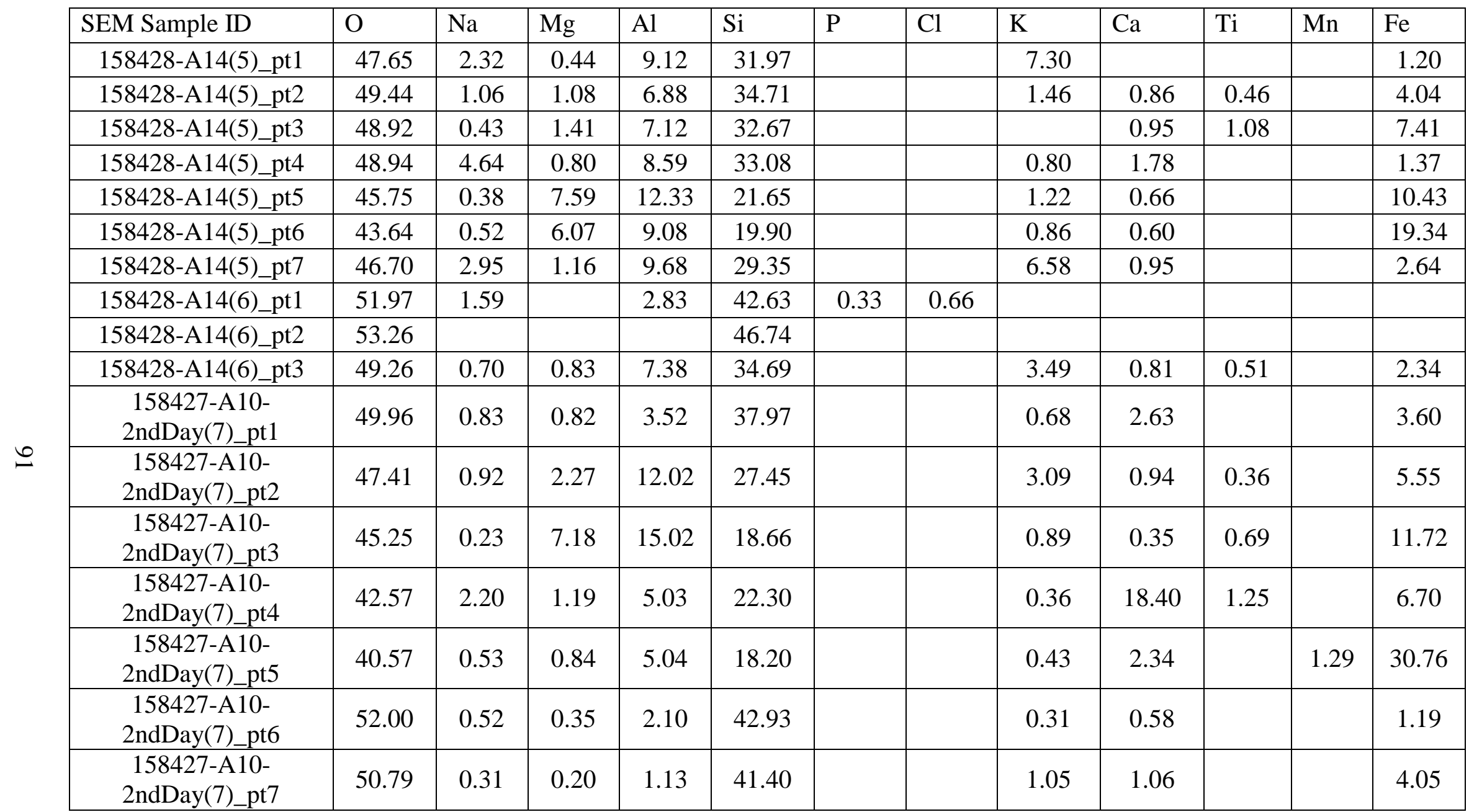


Table B2. Relative weight percentages of corresponding elements resulting from EDS analysis (continued)

\begin{tabular}{|c|c|c|c|c|c|c|c|c|c|c|c|c|c|}
\hline SEM Sample ID & $\mathrm{C}$ & $\mathrm{O}$ & $\mathrm{Na}$ & $\mathrm{Mg}$ & $\mathrm{Al}$ & $\mathrm{Si}$ & $\mathrm{S}$ & $\mathrm{Cl}$ & $\mathrm{K}$ & $\mathrm{Ca}$ & $\mathrm{Ti}$ & Mn & $\mathrm{Fe}$ \\
\hline $\begin{array}{c}\text { 158427-A10- } \\
\text { 2ndDay(7)_pt8 }\end{array}$ & & 53.22 & & & 0.28 & 46.49 & & & & & & & \\
\hline $\begin{array}{c}\text { 158427-A10- } \\
\text { 2ndDay(7)_pt9 }\end{array}$ & & 51.38 & 0.33 & 0.77 & 3.64 & 40.58 & & & 0.50 & 0.28 & & & 2.52 \\
\hline $\begin{array}{c}\text { 158427-A10- } \\
\text { 2ndDay(7)_pt10 }\end{array}$ & & 41.30 & & 0.52 & 1.09 & 23.20 & & & & 32.87 & & & 1.03 \\
\hline 158428-A14(1)_pt1 & 34.90 & 27.53 & 0.95 & 1.89 & 3.51 & 13.37 & & & 0.48 & 13.66 & 1.89 & & 1.82 \\
\hline 158428-A14(1)_pt2 & 20.22 & 34.89 & 1.23 & 2.73 & 5.95 & 17.83 & & & 1.31 & 11.71 & 1.43 & & 2.70 \\
\hline 158428-A14(1)_pt3 & 67.06 & 15.35 & 0.29 & 0.40 & 1.20 & 7.81 & 0.83 & & 1.04 & 1.33 & 4.28 & & 0.41 \\
\hline 158428-A14(1)_pt4 & 18.94 & 33.27 & 2.66 & 3.85 & 24.44 & & 1.50 & & 2.78 & 4.63 & & & 7.93 \\
\hline 158428-A14(2)_pt1 & & 40.55 & 1.67 & 1.33 & 38.62 & & & & 12.94 & & & & 4.89 \\
\hline 158428-A14(2)_pt2 & & 40.46 & 13.41 & 5.10 & 32.74 & & & & & 8.30 & & & \\
\hline 158428-A14(3)_pt1 & & 40.50 & 2.35 & 6.36 & 31.36 & & & & 3.02 & 2.42 & & & 13.98 \\
\hline 158428-A14(3)_pt2 & & 38.11 & 18.53 & & 29.29 & & & & & 14.07 & & & \\
\hline 158428-A14(4)_pt1 & & 39.23 & 6.50 & 5.13 & 24.04 & & & & 4.13 & 9.83 & 11.15 & & \\
\hline 158428-A14(4)_pt2 & & 36.68 & 11.93 & 5.32 & 23.43 & & & & 6.22 & 4.76 & & & 11.68 \\
\hline 158429-A15(1)_pt1 & & 100.00 & & & & & & & & & & & \\
\hline 158429-A15(1)_pt2 & & 38.60 & & & 28.75 & & & & & 32.65 & & & \\
\hline 158429-A15(1)_pt3 & & 47.07 & & & 52.93 & & & & & & & & \\
\hline 158429-A15(2)_pt1 & 76.56 & 9.24 & 6.27 & & 7.93 & & & & & & & & \\
\hline 158429-A15(2)_pt2 & 40.49 & 17.92 & 0.56 & 0.29 & 2.60 & & & & & 38.15 & & & \\
\hline 158429-A15(3)_pt1 & & 38.54 & 8.21 & 6.37 & 22.85 & & & & & 5.07 & 4.17 & & 14.79 \\
\hline 158429-A15(3)_pt2 & & 35.27 & 41.19 & & 23.54 & & & & & & & & \\
\hline 158429-A15(4)_pt1 & 80.79 & 8.69 & 0.49 & 0.03 & 9.38 & & & 0.14 & 0.17 & 0.32 & & & \\
\hline 158429-A15(4)_pt2 & & 37.71 & 15.68 & 8.59 & 23.29 & & & & & 14.73 & & & \\
\hline
\end{tabular}


Table B2. Relative weight percentages of corresponding elements resulting from EDS analysis (continued)

\begin{tabular}{|c|c|c|c|c|c|c|c|c|c|c|c|c|c|}
\hline SEM Sample ID & $\mathrm{C}$ & $\mathrm{O}$ & $\mathrm{Na}$ & $\mathrm{Mg}$ & $\mathrm{Al}$ & $\mathrm{Si}$ & $S$ & $\mathrm{Cl}$ & $\mathrm{K}$ & $\mathrm{Ca}$ & $\mathrm{Ti}$ & $\mathrm{Mn}$ & $\mathrm{Fe}$ \\
\hline 158429-A15(5)_pt1 & & 29.90 & & & & & & & & 7.32 & & & 62.78 \\
\hline 158429-A15(5)_pt2 & & 33.78 & 32.34 & & 18.37 & & & & & 15.51 & & & \\
\hline 158429-A15(5)_pt3 & & 38.16 & 9.81 & 6.28 & 26.54 & & & & 4.68 & 6.58 & & & 7.96 \\
\hline 158429-A15(5)_pt4 & & 39.73 & 6.84 & 4.69 & 32.42 & & & & 6.53 & 3.61 & & & 6.17 \\
\hline 158429-A15(6)_pt1 & & 37.71 & 21.32 & & 28.43 & & & & & 12.55 & & & \\
\hline 158429-A15(6)_pt2 & & 40.46 & 6.04 & 3.53 & 32.18 & & & & & 7.42 & & & 10.37 \\
\hline 158429-A15(6)_pt3 & & 100.0 & & & & & & & & & & & \\
\hline 158429-A15(6)_pt4 & & 37.75 & & & 36.52 & & & & 25.73 & & & & \\
\hline 158503(1)_pt1 & 5.67 & 53.59 & 0.33 & 0.96 & 2.37 & 27.99 & & & 0.37 & 0.75 & & 0.43 & 7.53 \\
\hline 158503(2)_pt1 & & 50.93 & 1.85 & 0.22 & 2.94 & 41.08 & & & 2.39 & 0.58 & & & \\
\hline 158503(2)_pt2 & & 48.83 & 5.89 & 1.20 & 1.36 & 37.62 & & & 0.57 & 4.52 & & & \\
\hline 158503(3)_pt1 & & 51.47 & 0.67 & & 5.09 & 40.60 & & & 2.17 & & & & \\
\hline 158503(4)_pt1 & & 53.01 & 0.60 & 0.11 & & 46.28 & & & & & & & \\
\hline 158503(4)_pt2 & & 50.94 & 0.46 & 0.41 & 1.27 & 41.42 & & & 0.29 & 3.48 & & & 1.73 \\
\hline 158503(4)_pt3 & & 53.03 & 0.48 & & 0.47 & 46.03 & & & & & & & \\
\hline 158503(4)_pt4 & & 52.30 & & 0.45 & 1.24 & 43.21 & 0.50 & & 0.23 & 0.35 & & & 1.73 \\
\hline 158503(4)_pt5 & & 53.15 & 0.30 & & & 46.56 & & & & & & & \\
\hline 158503(4)_pt6 & & 50.66 & 0.60 & 0.22 & 0.14 & 41.71 & & & & 6.66 & & & \\
\hline 158503(5)_pt1 & & 51.50 & 1.09 & 0.26 & 2.67 & 41.71 & & & 0.48 & 0.86 & & & 1.42 \\
\hline 158503(5)_pt2 & & 53.26 & & & & 46.74 & & & & & & & \\
\hline 158503(5)_pt3 & & 53.26 & & & & 46.74 & & & & & & & \\
\hline 158503(5)_pt4 & & 48.95 & 0.23 & 3.44 & 4.51 & 34.54 & & & 1.23 & 2.14 & & & 4.97 \\
\hline 158503(5)_pt5 & & 52.97 & 0.30 & & 0.66 & 45.85 & & & 0.23 & & & & \\
\hline 158503(5)_pt6 & & 50.18 & 0.47 & 0.17 & 0.73 & 40.08 & & & & 0.35 & & & 8.02 \\
\hline 158503(5)_pt7 & & 51.56 & 0.74 & 0.58 & 3.13 & 41.36 & & & 0.48 & 0.60 & & & 1.55 \\
\hline
\end{tabular}


Table B2. Relative weight percentages of corresponding elements resulting from EDS analysis (continued)

\begin{tabular}{|c|c|c|c|c|c|c|c|c|c|c|c|c|}
\hline SEM Sample ID & $\mathrm{C}$ & $\mathrm{O}$ & $\mathrm{Na}$ & $\mathrm{Mg}$ & $\mathrm{Al}$ & $\mathrm{Si}$ & $\mathrm{S}$ & $\mathrm{Cl}$ & $\mathrm{K}$ & $\mathrm{Ca}$ & $\mathrm{Ti}$ & $\mathrm{Fe}$ \\
\hline 158504(1)_pt1 & & 51.55 & 0.41 & 0.34 & 2.70 & 41.78 & & & 0.90 & & & 2.31 \\
\hline 158504(1)_pt2 & & 51.02 & 0.19 & 0.21 & 0.30 & 42.16 & & & & 4.11 & & 2.00 \\
\hline 158504(1)_pt3 & & 49.88 & 0.26 & 2.12 & 10.04 & 32.49 & 0.36 & & 0.75 & & & 4.10 \\
\hline 158504(1)_pt4 & 10.20 & 56.34 & 0.27 & 3.41 & 0.70 & 19.57 & 0.13 & & 0.30 & 8.16 & & 0.93 \\
\hline 158504(2)_pt1 & & 53.13 & 0.35 & & 46.52 & & & & & & & \\
\hline 158504(2)_pt2 & & 51.3 & 0.54 & 2.65 & 42.26 & 3.19 & & & & & & \\
\hline 158504(2)_pt3 & & 52.8 & 0.84 & 0.13 & 45.97 & 0.21 & & & & & & \\
\hline 158504(3)_pt1 & & 48.0 & 0.45 & 3.90 & 0.98 & 34.42 & 0.74 & & & 9.88 & & 1.24 \\
\hline 158504(3)_pt2 & & 52.05 & 0.87 & & 1.71 & 43.05 & 0.38 & & 0.85 & 1.09 & & \\
\hline 158504(3)_pt3 & & 50.36 & 0.70 & 0.83 & 1.94 & 38.85 & 0.47 & & 0.20 & 0.59 & & 6.06 \\
\hline 158504(3)_pt4 & & 48.99 & 0.46 & 3.27 & 1.85 & 36.05 & & & 0.28 & 4.95 & 0.58 & 3.56 \\
\hline 158504(3)_pt5 & & 53.07 & 0.49 & & & 46.43 & & & & & & \\
\hline 158504(3)_pt6 & & 53.26 & & & & 46.74 & & & & & & \\
\hline 158504(3)_pt7 & & 53.00 & 0.61 & 0.12 & & 46.26 & & & & & & \\
\hline 158504(3)_pt8 & & 52.07 & 0.62 & 0.31 & 0.64 & 43.60 & & & 0.31 & 0.38 & 1.24 & 0.83 \\
\hline 158504(3)_pt9 & & 51.33 & 3.09 & 0.30 & 3.06 & 41.22 & & & 0.25 & & & 0.76 \\
\hline 158504(3)_pt10 & & 53.11 & 0.41 & & & 46.49 & & & & & & \\
\hline 158507 A-27 (A)(1)_pt1 & 27.12 & 29.23 & 0.28 & 0.19 & 0.37 & 15.64 & & & & 26.65 & & 0.54 \\
\hline 158507 A-27 (A)(1)_pt2 & 8.30 & 46.29 & 0.48 & 1.50 & 4.41 & 34.49 & & & 0.33 & 0.68 & 0.25 & 3.26 \\
\hline 158507 A-27 (A)(1)_pt3 & 5.42 & 45.90 & 0.95 & 2.10 & 7.00 & 30.61 & & & 1.58 & & & 6.44 \\
\hline 158507 A-27 (A)(1)_pt4 & 19.33 & 35.96 & 0.40 & 4.40 & 6.81 & 18.27 & 0.11 & 0.14 & 2.06 & 1.34 & 0.64 & 10.54 \\
\hline 158509 A-27 (C)(1)_pt1 & 38.50 & 24.76 & 0.34 & 7.25 & 0.49 & 10.69 & & & & 15.42 & & 2.56 \\
\hline 158509 A-27 (C)(1)_pt2 & 6.51 & 46.44 & 4.33 & & 7.33 & 32.87 & & & 0.21 & 2.30 & & \\
\hline 158509 A-27 (C)(1)_pt3 & 5.98 & 49.42 & 0.39 & 0.15 & 1.87 & 41.61 & & & 0.58 & & & \\
\hline 158509 A-27 (C)(1)_pt4 & 21.00 & 40.66 & 0.27 & 0.40 & 1.33 & 33.24 & & & 0.19 & 1.37 & & 1.53 \\
\hline
\end{tabular}


Table B2. Relative weight percentages of corresponding elements resulting from EDS analysis (continued)

\begin{tabular}{|c|c|c|c|c|c|c|c|c|c|c|c|c|c|c|}
\hline $\begin{array}{c}\text { SEM Sample } \\
\text { ID }\end{array}$ & $\mathrm{C}$ & $\mathrm{O}$ & $\mathrm{Na}$ & $\mathrm{Mg}$ & $\mathrm{Al}$ & $\mathrm{Si}$ & $\mathrm{P}$ & $\mathrm{S}$ & $\mathrm{Cl}$ & $\mathrm{K}$ & $\mathrm{Ca}$ & $\mathrm{Ti}$ & $\mathrm{Fe}$ & $\mathrm{Cu}$ \\
\hline $\begin{array}{c}158510 \text { A- } \\
27 \text { (D)(1)_pt1 }\end{array}$ & 6.26 & 46.23 & 0.79 & 0.99 & 6.63 & 32.19 & & & & 1.36 & 0.45 & 0.36 & 4.75 & \\
\hline $\begin{array}{c}158510 \mathrm{~A}- \\
27(\mathrm{D})(1) \_\mathrm{pt} 2\end{array}$ & 8.52 & 44.44 & 0.56 & 0.56 & 10.32 & 28.91 & & & & 4.97 & & & 1.73 & \\
\hline $\begin{array}{c}158510 \mathrm{~A}- \\
27(\mathrm{D})(1) \_\mathrm{pt} 3\end{array}$ & $\begin{array}{c}63.1 \\
2 \\
\end{array}$ & 16.98 & & 0.42 & 1.96 & 10.85 & & & & 0.54 & 4.70 & & 1.44 & \\
\hline $\begin{array}{c}158510 \text { A- } \\
27 \text { (D)(1)_pt4 }\end{array}$ & 4.05 & 50.67 & 0.46 & & & 44.06 & & & & & 0.77 & & & \\
\hline 158506(5)_pt1 & $\begin{array}{c}35.8 \\
9\end{array}$ & 31.80 & 0.69 & 0.45 & 1.57 & 24.07 & & 0.70 & 0.67 & 0.92 & 0.83 & 0.27 & 1.43 & 0.71 \\
\hline 158506(2)_pt1 & & 37.63 & 0.98 & 1.06 & 3.66 & 12.52 & & 0.23 & 0.49 & 0.39 & 1.02 & 0.75 & 41.27 & \\
\hline 158506(2)_pt2 & & 52.48 & 1.10 & 0.34 & 0.76 & 44.72 & & & & & 0.60 & & & \\
\hline 158506(2)_pt3 & & 50.34 & 1.13 & 0.87 & 5.23 & 37.84 & & & & 1.40 & 1.66 & & 1.53 & \\
\hline 158506(2)_pt4 & & 52.97 & 0.54 & 0.23 & 0.33 & 45.93 & & & & & & & & \\
\hline 158506(2)_pt5 & & 52.48 & 0.79 & 0.25 & 0.45 & 45.25 & & & & & & & & 0.78 \\
\hline 158506(2)_pt6 & & 52.68 & 0.73 & 0.16 & 0.68 & 45.26 & & & & 0.23 & 0.26 & & & \\
\hline 158506(3)_pt1 & & 50.21 & 0.95 & 1.06 & 7.17 & 36.11 & & & & 1.11 & 0.58 & & 2.81 & \\
\hline 158506(3)_pt2 & & 46.95 & 0.54 & 1.12 & 6.34 & 17.20 & & 8.91 & & 1.30 & 12.72 & & 4.91 & \\
\hline 158506(3)_pt4 & & 51.34 & 1.04 & 0.30 & 4.08 & 40.40 & & & & 0.38 & 0.53 & & 1.91 & \\
\hline 158506(4)_pt1 & & 51.55 & 0.86 & 0.38 & 1.46 & 40.69 & & 1.38 & 0.31 & 0.59 & 1.38 & & 1.39 & \\
\hline 158506(4)_pt2 & & 51.34 & 0.59 & 0.50 & 1.74 & 41.29 & 0.51 & & & 0.54 & 1.42 & & 2.07 & \\
\hline 158506(4)_pt3 & & 51.21 & 0.69 & 0.62 & 3.35 & 39.71 & & 0.50 & & 0.65 & 1.25 & 0.41 & 1.61 & \\
\hline 158506(4)_pt4 & & 53.11 & 0.39 & & 0.03 & 46.47 & & & & & & & & \\
\hline 158506(6)_pt1 & & 50.84 & 0.82 & 0.78 & 8.64 & 36.33 & & & & 0.60 & 0.45 & & 1.55 & \\
\hline 158506(6)_pt2 & & 49.05 & 1.50 & 0.80 & 7.40 & 34.38 & & & & 2.91 & 1.71 & & 2.26 & \\
\hline 158506(6)_pt3 & & 52.71 & 0.61 & 0.22 & 0.71 & 45.26 & & & & 0.26 & 0.23 & & & \\
\hline 158506(6)_pt4 & & 53.23 & & & 0.24 & 46.53 & & & & & & & & \\
\hline
\end{tabular}


Table B2. Relative weight percentages of corresponding elements resulting from EDS analysis (continued)

\begin{tabular}{|c|c|c|c|c|c|c|c|c|c|c|c|c|c|}
\hline SEM Sample ID & $\mathrm{C}$ & $\mathrm{O}$ & $\mathrm{Na}$ & $\mathrm{Mg}$ & $\mathrm{Al}$ & $\mathrm{Si}$ & $\mathrm{P}$ & $\mathrm{S}$ & $\mathrm{Cl}$ & $\mathrm{K}$ & $\mathrm{Ca}$ & $\mathrm{Ti}$ & $\mathrm{Fe}$ \\
\hline 158506(7)_pt1 & & 51.52 & 1.12 & 0.53 & 2.98 & 41.44 & & & & 0.34 & 1.29 & & 0.78 \\
\hline 158506(7)_pt2 & & 49.72 & 0.43 & 3.28 & 2.16 & 34.94 & & 1.40 & & 0.27 & 1.57 & 0.97 & 5.26 \\
\hline 6-8-15(1)_pt1 & 11.73 & 57.68 & 0.78 & 0.71 & 3.75 & 16.66 & & & & 0.76 & 5.75 & & 2.18 \\
\hline 6-8-15(1)_pt2 & & 52.45 & & & 0.42 & 44.93 & & & & & 2.20 & & \\
\hline 6-8-15(1)_pt3 & & 52.50 & 0.65 & & 1.17 & 44.59 & & & & & 1.09 & & \\
\hline 6-8-15(1)_pt4 & 4.51 & 52.33 & 1.51 & 0.16 & 7.35 & 27.48 & & & & 4.28 & 1.72 & & 0.66 \\
\hline 158514(2)_pt1 & & 53.05 & 0.33 & 0.17 & 0.42 & 46.03 & & & & & & & \\
\hline 158514(2)_pt2 & & 50.58 & 0.42 & 0.86 & 3.14 & 39.37 & & & & 0.75 & 0.93 & & 3.95 \\
\hline 158514(2)_pt3 & & 49.90 & 1.17 & 1.79 & 8.57 & 34.51 & & & & 1.58 & 0.79 & & 1.70 \\
\hline 158514(2)_pt4 & & 48.18 & 3.94 & 0.27 & 8.65 & 31.32 & & 0.74 & & 3.29 & 2.39 & & 1.21 \\
\hline 158514(2)_pt5 & & 51.71 & 0.41 & 0.51 & 3.04 & 41.92 & & & & 1.19 & & & 1.22 \\
\hline 158515(1)_pt1 & & 52.60 & 0.71 & & 0.66 & 45.25 & & & & 0.50 & 0.27 & & \\
\hline 158515(1)_pt2 & & 52.51 & 0.61 & 0.56 & 2.00 & 43.96 & & & & 0.36 & & & \\
\hline 158515(1)_pt3 & & 47.74 & 0.86 & 0.75 & 3.54 & 32.94 & & & & 0.28 & 1.44 & 1.22 & 11.24 \\
\hline 158515(1)_pt4 & & 50.24 & 0.52 & 1.33 & 0.91 & 39.79 & & & & 0.24 & & & 6.97 \\
\hline 158515(1)_pt5 & & 53.08 & 0.43 & & 0.10 & 46.38 & & & & & & & \\
\hline 158515(1)_pt6 & & 52.59 & 1.11 & 0.31 & 0.33 & 45.24 & & & & & 0.42 & & \\
\hline 158516(1)_pt1 & & 53.10 & 0.39 & & 0.08 & 46.43 & & & & & & & \\
\hline 158516(1)_pt2 & & 53.05 & 0.34 & & & 46.38 & & & & & 0.22 & & \\
\hline 158516(1)_pt3 & & 52.52 & 0.55 & 0.19 & 0.85 & 44.80 & & & & 0.23 & 0.24 & 0.62 & \\
\hline 158517(1)_pt1 & & 53.19 & & 0.17 & 0.22 & 46.42 & & & & & & & \\
\hline 158517(1)_pt2 & & 50.09 & 0.36 & 0.61 & 1.82 & 39.18 & & & & 0.48 & & & 7.45 \\
\hline 158517(1)_pt3 & & 48.85 & 1.30 & 0.97 & 5.22 & 33.73 & & 0.64 & & 0.65 & 3.63 & & 5.01 \\
\hline 158517(1)_pt4 & & 52.78 & 0.30 & & & 45.87 & & & & & 1.05 & & \\
\hline 158518(1)_pt1 & & 50.50 & 0.67 & 0.64 & 2.36 & 39.71 & & & & 0.51 & 0.43 & & 5.18 \\
\hline 158518(1)_pt2 & & 50.27 & 2.76 & 0.56 & 5.49 & 37.64 & & & & 0.88 & 1.28 & & 1.11 \\
\hline 158518(1)_pt3 & & 50.34 & 0.93 & 0.25 & 3.43 & 39.78 & & & & 3.38 & 0.62 & & 1.26 \\
\hline 158518(1)_pt4 & & 52.31 & 1.24 & 0.51 & 0.29 & 44.67 & & & & & 0.99 & & \\
\hline 158518(1)_pt5 & & 49.44 & 1.59 & 0.85 & 4.32 & 36.40 & & & & 0.57 & 1.43 & & 5.40 \\
\hline
\end{tabular}


Table B2. Relative weight percentages of corresponding elements resulting from EDS analysis (continued)

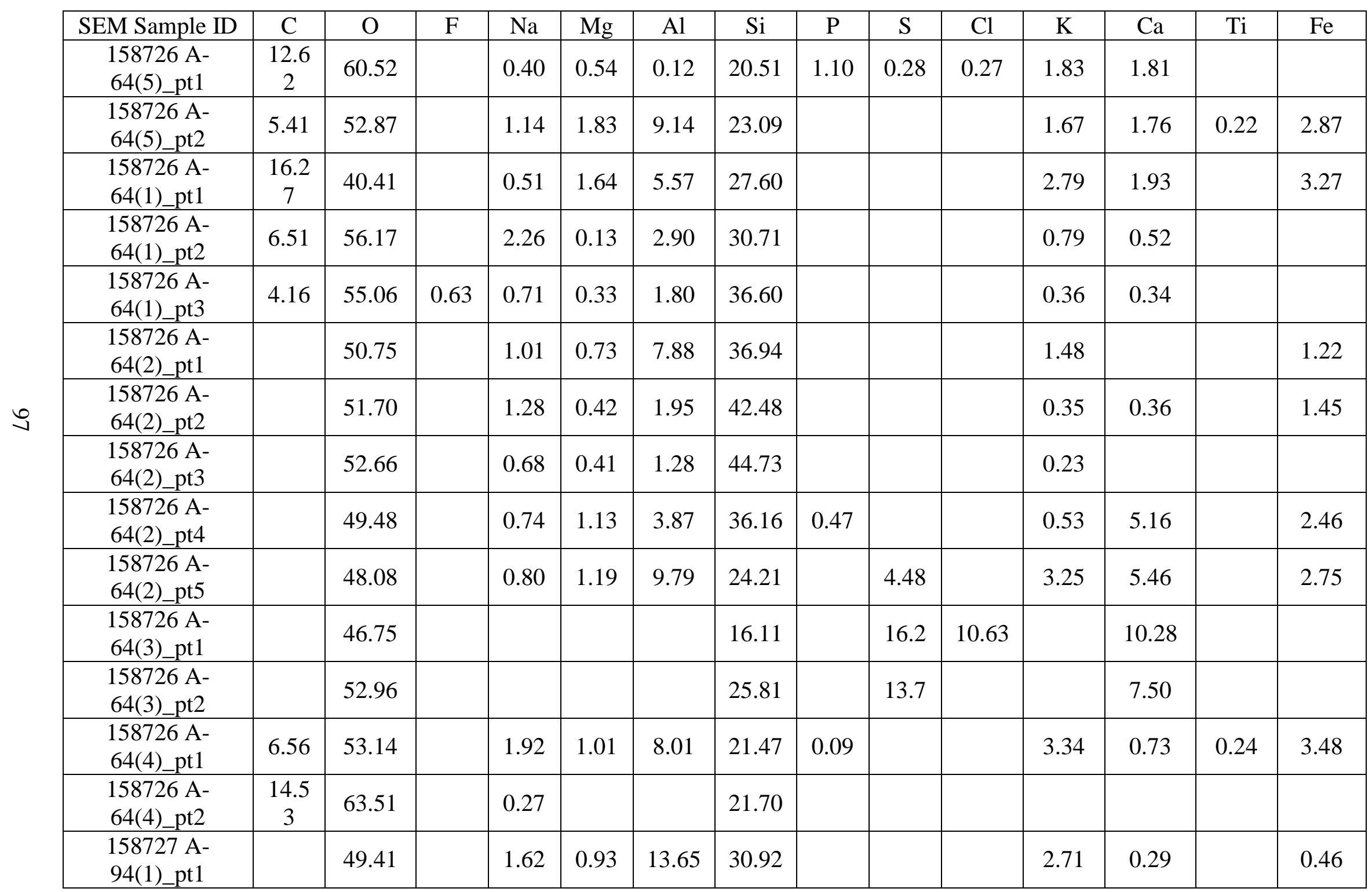


Table B2. Relative weight percentages of corresponding elements resulting from EDS analysis (continued)

\begin{tabular}{|c|c|c|c|c|c|c|c|c|c|c|c|c|c|}
\hline SEM Sample ID & $\mathrm{O}$ & $\mathrm{Na}$ & $\mathrm{Mg}$ & $\mathrm{Al}$ & $\mathrm{Si}$ & $\mathrm{P}$ & $S$ & $\mathrm{Cl}$ & $\mathrm{K}$ & $\mathrm{Ca}$ & $\mathrm{Ti}$ & $\mathrm{Fe}$ & Mo \\
\hline $\begin{array}{l}158727 \text { A- } \\
94(1) \_p t 2\end{array}$ & 51.20 & 1.75 & 1.47 & 5.11 & 39.17 & & & & 0.40 & 0.39 & & 0.52 & \\
\hline $\begin{array}{l}158727 \text { A- } \\
94(1) \_p t 3\end{array}$ & 48.45 & 7.99 & 0.44 & 9.60 & 31.73 & & & & 0.22 & 0.84 & & 0.72 & \\
\hline $\begin{array}{l}158727 \mathrm{~A}- \\
94 \text { (1)_pt1 }\end{array}$ & 53.03 & 0.21 & & 0.30 & 46.13 & & & & & 0.35 & & & \\
\hline $\begin{array}{l}158727 \mathrm{~A}- \\
94(1) \_\mathrm{pt} 2\end{array}$ & 53.05 & 0.55 & & & 46.40 & & & & & & & & \\
\hline $\begin{array}{l}158727 \mathrm{~A}- \\
94(1) \_\mathrm{pt} 3\end{array}$ & 49.91 & 0.32 & 2.35 & 0.98 & 38.90 & & & & & 5.76 & & 1.78 & \\
\hline $\begin{array}{l}158727 \mathrm{~A}- \\
94(2) \_\mathrm{pt} 1\end{array}$ & 46.79 & 1.92 & 2.19 & 8.41 & 29.51 & & & 1.63 & 2.56 & 1.52 & 0.40 & 5.08 & \\
\hline $\begin{array}{l}158727 \mathrm{~A}- \\
94 \text { (2)_pt2 }\end{array}$ & 53.14 & 0.21 & & 0.31 & 46.34 & & & & & & & & \\
\hline $\begin{array}{l}158727 \mathrm{~A}- \\
94 \text { (3)_pt1 }\end{array}$ & 48.58 & & 2.27 & 1.41 & 8.86 & 31.28 & 0.25 & & 0.98 & 1.69 & 0.58 & 4.10 & \\
\hline $\begin{array}{l}158727 \mathrm{~A}- \\
94(3) \_p t 2\end{array}$ & 41.01 & 0.32 & 0.51 & 13.86 & 1.84 & 14.43 & & 2.30 & 0.42 & 25.31 & & & \\
\hline $\begin{array}{l}158727 \mathrm{~A}- \\
94(3) \_p t 3\end{array}$ & 53.08 & & 0.45 & & 0.08 & 46.39 & & & & & & & \\
\hline $\begin{array}{l}158727 \mathrm{~A}- \\
94(3) \_\mathrm{pt} 4\end{array}$ & 40.15 & & 0.61 & 0.75 & 1.39 & 20.88 & & & 0.28 & 35.33 & & 0.62 & \\
\hline $\begin{array}{l}158727 \mathrm{~A}- \\
94 \text { (3)_pt5 }\end{array}$ & 30.06 & & & & & & & & & & & 69.94 & \\
\hline $\begin{array}{l}158727 \mathrm{~A}- \\
94 \text { (4)_pt1 }\end{array}$ & 53.02 & 0.56 & & 0.23 & 46.19 & & & & & & & & \\
\hline $\begin{array}{l}158727 \mathrm{~A}- \\
94(4) \_\mathrm{pt} 2\end{array}$ & 50.85 & 0.53 & 0.79 & 2.18 & 41.05 & & & 0.24 & 0.25 & 2.01 & & 1.37 & 0.74 \\
\hline
\end{tabular}


Table B2. Relative weight percentages of corresponding elements resulting from EDS analysis (continued)

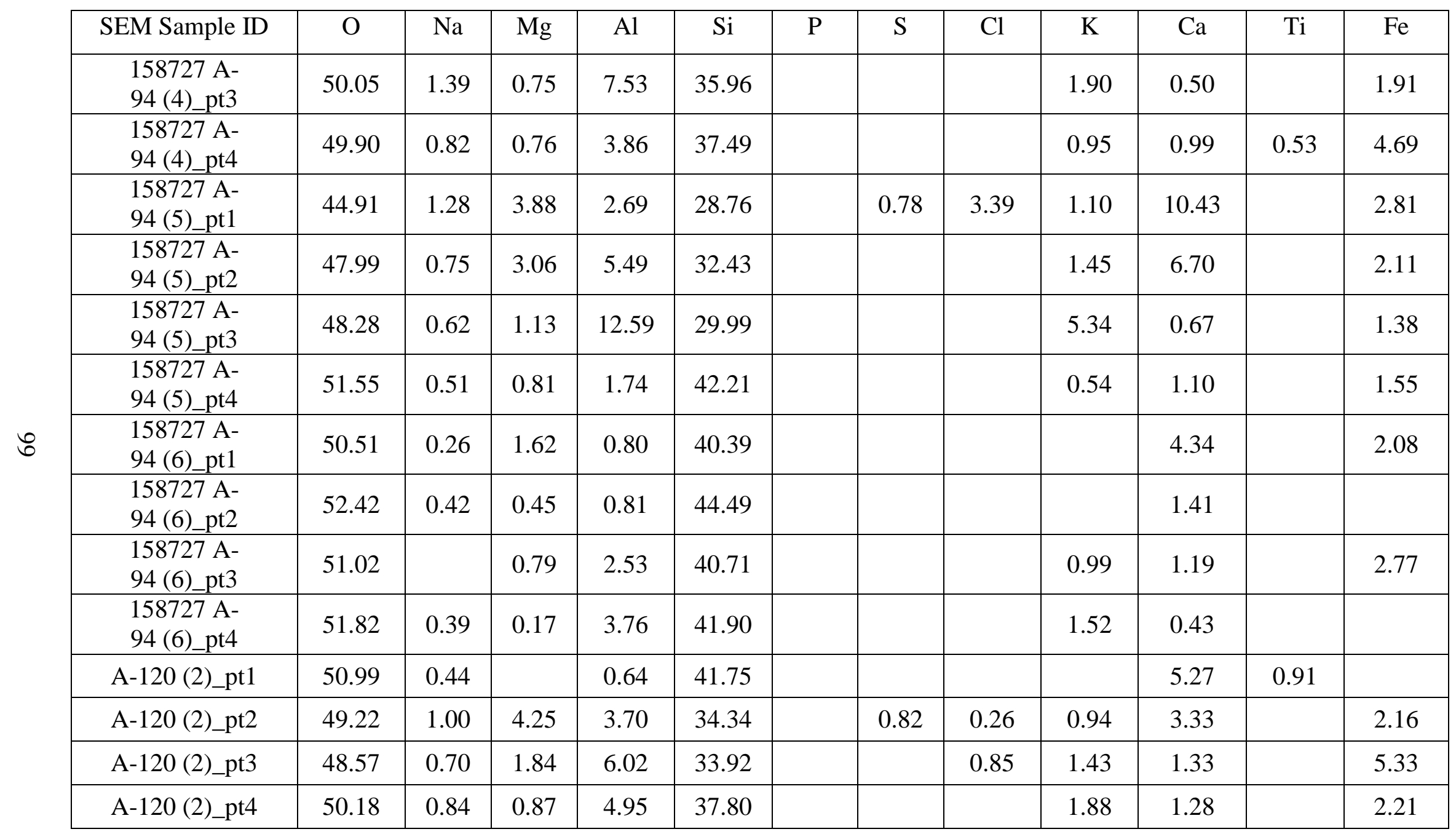


Table B2. Relative weight percentages of corresponding elements resulting from EDS analysis (continued)

\begin{tabular}{|c|c|c|c|c|c|c|c|c|c|c|c|c|c|}
\hline SEM Sample ID & $\mathrm{C}$ & $\mathrm{O}$ & $\mathrm{Na}$ & $\mathrm{Mg}$ & $\mathrm{Al}$ & $\mathrm{Si}$ & $\mathrm{P}$ & $\mathrm{S}$ & $\mathrm{Cl}$ & $\mathrm{K}$ & $\mathrm{Ca}$ & $\mathrm{Ti}$ & $\mathrm{Fe}$ \\
\hline A-120 (1)_pt1 & & 52.01 & 0.35 & 0.30 & 2.50 & 42.93 & & & & 1.06 & 0.84 & & \\
\hline A-120 (1)_pt2 & & 49.83 & 0.83 & 0.60 & 4.86 & 36.71 & & & & 1.19 & 0.68 & 0.88 & 4.42 \\
\hline A-120 (1)_pt3 & & 53.26 & & & & 46.74 & & & & & & & \\
\hline A-120 (1)_pt4 & & 50.96 & 0.87 & 0.65 & 3.66 & 39.92 & & & & 0.69 & 1.58 & & 1.65 \\
\hline A-129(2)_pt2 & 81.92 & 9.45 & 0.18 & & & 7.66 & & 0.39 & 0.17 & 0.09 & 0.15 & & \\
\hline A-129(5)_pt1 & 65.44 & 17.25 & 0.66 & & 0.18 & 13.27 & & 0.92 & 0.87 & 1.07 & 0.36 & & \\
\hline A-129(5)_pt2 & 60.15 & 20.67 & 0.56 & & & 17.47 & & 0.27 & 0.27 & 0.40 & 0.20 & & \\
\hline A-129(6)_pt1 & 87.56 & 6.23 & 0.23 & 0.16 & & 4.34 & & 0.60 & 0.27 & 0.20 & 0.41 & & \\
\hline A-129(11)_pt4 & 54.17 & 24.09 & 0.51 & 0.19 & 0.28 & 20.13 & 0.41 & & & & 0.23 & & \\
\hline A-129(12)_pt1 & 71.20 & 14.31 & 0.71 & & & 11.75 & & 0.32 & 0.90 & 0.63 & 0.18 & & \\
\hline A-129(12)_pt2 & 6.69 & 49.69 & & & & 43.61 & & & & & & & \\
\hline A-150(1)_pt1 & 74.26 & 13.57 & 0.69 & & & 9.76 & 1.72 & & & & & & \\
\hline A-150(1)_pt2 & 66.77 & 17.11 & 0.88 & 0.21 & 0.03 & 13.15 & 1.24 & & 0.08 & 0.22 & 0.31 & & \\
\hline A-150(4)_pt1 & 61.13 & 20.60 & 0.20 & & & 17.61 & & 0.26 & & & 0.19 & & \\
\hline A-150(4)_pt2 & 68.89 & 16.48 & 0.21 & & 0.09 & 13.89 & & 0.29 & & & 0.15 & & \\
\hline A-150(4)_pt3 & 78.28 & 11.45 & 0.15 & & & 9.64 & & 0.20 & & & 0.28 & & \\
\hline
\end{tabular}


Table B2. Relative weight percentages of corresponding elements resulting from EDS analysis (continued)

\begin{tabular}{|c|c|c|c|c|c|c|c|c|c|c|c|c|c|}
\hline SEM Sample ID & $\mathrm{C}$ & $\mathrm{O}$ & $\mathrm{Na}$ & $\mathrm{Mg}$ & $\mathrm{Al}$ & $\mathrm{Si}$ & $\mathrm{P}$ & $\mathrm{S}$ & $\mathrm{Cl}$ & $\mathrm{K}$ & $\mathrm{Ca}$ & $\mathrm{Ti}$ & $\mathrm{Fe}$ \\
\hline A-150(9)_pt1 & 60.59 & 13.90 & 0.55 & 0.54 & 0.24 & 8.57 & & 1.12 & 6.21 & 8.28 & & & \\
\hline A-150(13)_pt1 & 77.22 & 11.83 & 0.21 & & & 9.14 & & 0.76 & 0.35 & & 0.49 & & \\
\hline A-150(13)_pt2 & 9.86 & 47.86 & 0.38 & & & 41.90 & & & & & & & \\
\hline A-150(14)_pt1 & 90.95 & 4.82 & & & & 4.23 & & & & & & & \\
\hline A-150(15)_pt1 & 54.88 & 23.75 & 0.16 & & 0.03 & 20.73 & & & 0.23 & 0.23 & & & \\
\hline
\end{tabular}

\section{Table B3}

Particulate matter type with respect to filters

\begin{tabular}{|c|c|}
\hline \multirow{5}{*}{} & Particulate matter type \\
\hline Filter No. & $\mathrm{PM}_{10}$ \\
\hline $\mathrm{A}-9$ & $\mathrm{PM}_{2.5}$ \\
\hline $\mathrm{A}-10$ & $\mathrm{PM}_{10}$ \\
\hline $\mathrm{A}-14$ & $\mathrm{PM}_{2.5}$ \\
\hline $\mathrm{A}-15$ & $\mathrm{PM}_{2.5}$ \\
\hline $\mathrm{A}-25$ & $\mathrm{PM}_{10}$ \\
\hline $\mathrm{A}-27$ & $\mathrm{PM}_{10}$ \\
\hline $\mathrm{A}-30$ & $\mathrm{PM}_{2.5}$ \\
\hline $\mathrm{A}-31$ & $\mathrm{PM}_{10}$ \\
\hline $\mathrm{A}-64$ & $\mathrm{PM}_{10}$ \\
\hline $\mathrm{A}-94$ & $\mathrm{TSP}$ \\
\hline $\mathrm{A}-120$ & $\mathrm{PM}_{10}$ \\
\hline $\mathrm{A}-129$ & $\mathrm{PM}_{10}$ \\
\hline $\mathrm{A}-150$ & \\
\hline & \\
\hline
\end{tabular}


Table B4

Particulate matter identification

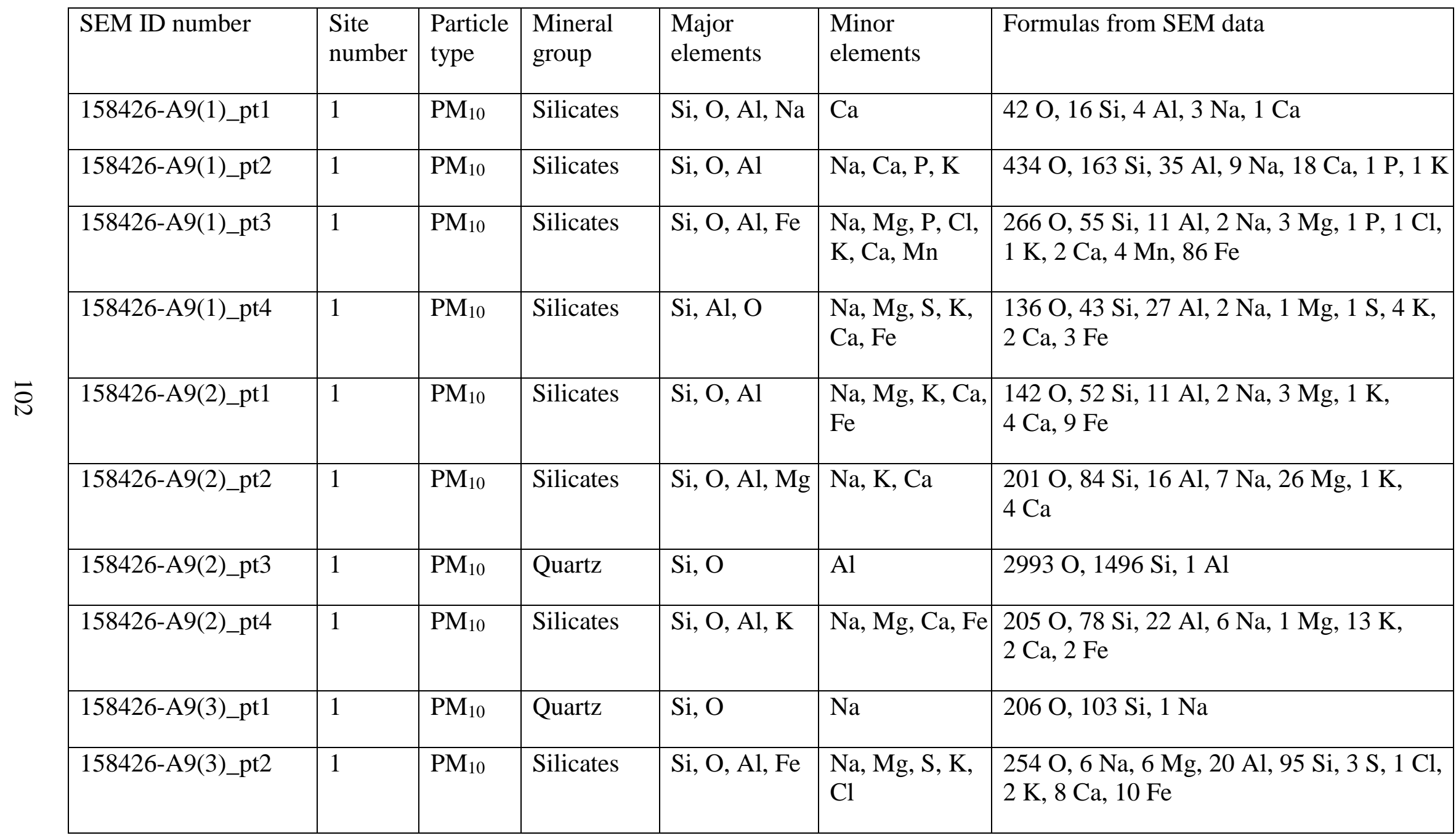


Table B4. Particulate matter identification (continued)

\begin{tabular}{|c|c|c|c|c|c|c|}
\hline SEM ID number & $\begin{array}{l}\text { Site } \\
\text { number }\end{array}$ & $\begin{array}{l}\text { Particle } \\
\text { type }\end{array}$ & $\begin{array}{l}\text { Mineral } \\
\text { group }\end{array}$ & $\begin{array}{l}\text { Major } \\
\text { elements }\end{array}$ & $\begin{array}{l}\text { Minor } \\
\text { elements }\end{array}$ & Formulas from SEM data \\
\hline 158426-A9(3)_pt3 & 1 & $\mathrm{PM}_{10}$ & Silicates & $\mathrm{Si}, \mathrm{O}, \mathrm{Na}$ & $\mathrm{Mg}, \mathrm{Al}, \mathrm{K}, \mathrm{Ca}$ & $\begin{array}{l}353 \mathrm{O}, 429 \mathrm{Na}, 2 \mathrm{Mg}, 6 \mathrm{Al}, 169 \mathrm{Si}, 2 \mathrm{~K}, \\
1 \mathrm{Cl}\end{array}$ \\
\hline 158426-A9(4)_pt1 & 1 & $\mathrm{PM}_{10}$ & Quartz & $\mathrm{Si}, \mathrm{O}$ & $\mathrm{Na}, \mathrm{Al}, \mathrm{Ca}, \mathrm{Ti}$ & $265 \mathrm{O}, 7 \mathrm{Na}, 2 \mathrm{Al}, 123 \mathrm{Si}, 11 \mathrm{Ca}, 1 \mathrm{Ti}$ \\
\hline 158426-A9(4)_pt3 & 1 & $\mathrm{PM}_{10}$ & Quartz & $\mathrm{Si}, \mathrm{O}$ & $\mathrm{Na}$ & $206 \mathrm{O}, 119 \mathrm{Si}, 1 \mathrm{Na}$ \\
\hline 158426-A9(5)_pt1 & 1 & $\mathrm{PM}_{10}$ & Chlorides & $\mathrm{Na}, \mathrm{Cl}$ & $\mathrm{O}, \mathrm{S}, \mathrm{K}, \mathrm{Ca}, \mathrm{Si}$ & $27 \mathrm{Na}, 3 \mathrm{O}, 1 \mathrm{Si}, 3 \mathrm{~S}, 5 \mathrm{Cl}, 4 \mathrm{~K}, 1 \mathrm{Ca}$ \\
\hline 158426-A9(5)_pt2 & 1 & $\mathrm{PM}_{10}$ & Chlorides & $\mathrm{O}, \mathrm{Na}, \mathrm{Cl}$ & $\mathrm{Al}, \mathrm{Si}, \mathrm{S}, \mathrm{K}, \mathrm{Ca}$ & $\begin{array}{l}55 \mathrm{O}, 35 \mathrm{Na}, 1 \mathrm{Al}, 6 \mathrm{Si}, 6 \mathrm{~S}, 21 \mathrm{Cl}, 8 \mathrm{~K}, \\
2 \mathrm{Ca}\end{array}$ \\
\hline 158426-A9(5)_pt4 & 1 & $\mathrm{PM}_{10}$ & Chlorides & $\begin{array}{l}\mathrm{Na}, \mathrm{O}, \mathrm{Si}, \mathrm{Cl}, \\
\mathrm{K}\end{array}$ & $\mathrm{Al}, \mathrm{S}$ & $157 \mathrm{O}, 59 \mathrm{Na}, 1 \mathrm{Al}, 49 \mathrm{Si}, 3 \mathrm{~S}, 34 \mathrm{Cl}, 34 \mathrm{~K}$ \\
\hline 158426-A9(6)_pt1 & 1 & $\mathrm{PM}_{10}$ & Quartz & $\mathrm{Si}, \mathrm{O}$ & & $2 \mathrm{O}, 1 \mathrm{Si}$ \\
\hline 158426-A9(6)_pt2 & 1 & $\mathrm{PM}_{10}$ & Quartz & $\mathrm{Si}, \mathrm{O}$ & $\begin{array}{l}\mathrm{Na}, \mathrm{Mg}, \mathrm{Al}, \mathrm{P} \\
\mathrm{S}, \mathrm{K}, \mathrm{Cl}\end{array}$ & $\begin{array}{l}514 \mathrm{O}, 4 \mathrm{Na}, 4 \mathrm{Mg}, 1 \mathrm{Al}, 228 \mathrm{Si}, 5 \mathrm{P}, \\
9 \mathrm{~S}, 8 \mathrm{~K}, 7 \mathrm{Ca}\end{array}$ \\
\hline
\end{tabular}


Table B4. Particulate matter identification (continued)

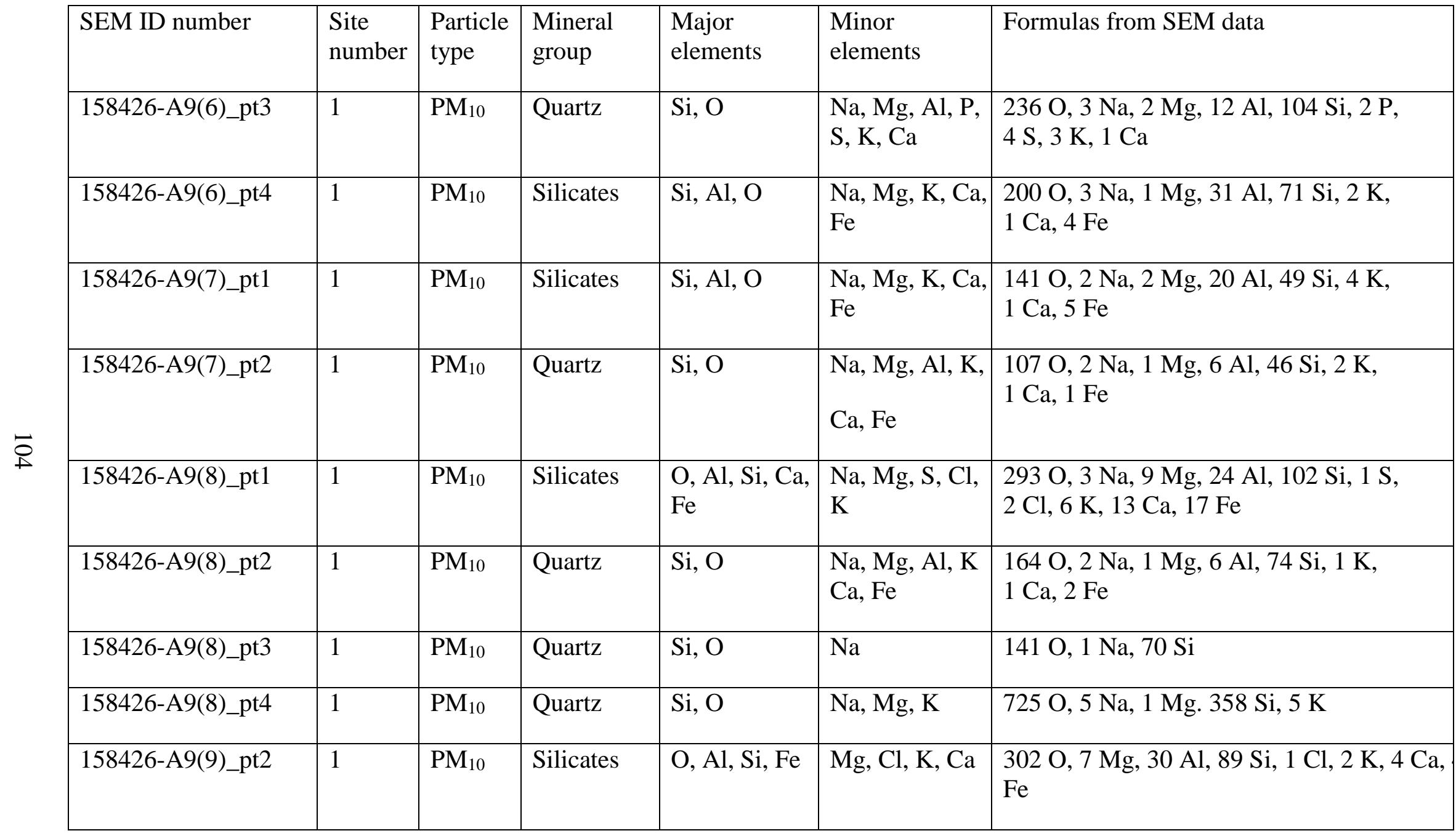


Table B4. Particulate matter identification (continued)

\begin{tabular}{|c|c|c|c|c|c|c|}
\hline SEM ID number & $\begin{array}{l}\text { Site } \\
\text { number }\end{array}$ & $\begin{array}{l}\text { Particle } \\
\text { type }\end{array}$ & $\begin{array}{l}\text { Mineral } \\
\text { group }\end{array}$ & $\begin{array}{l}\text { Major } \\
\text { elements }\end{array}$ & $\begin{array}{l}\text { Minor } \\
\text { elements }\end{array}$ & Formulas from SEM data \\
\hline 158426-A9(8)_pt5 & 1 & $\mathrm{PM}_{10}$ & Silicates & $\mathrm{O}, \mathrm{Si}, \mathrm{Al}$ & $\begin{array}{l}\mathrm{Na}, \mathrm{Mg}, \mathrm{S}, \mathrm{K} \\
\mathrm{Ca}, \mathrm{Ti}, \mathrm{Fe}\end{array}$ & $\begin{array}{l}444 \mathrm{O}, 5 \mathrm{Na}, 8 \mathrm{Mg}, 59 \mathrm{Al}, 158 \mathrm{Si}, 1 \mathrm{~S}, 7 \mathrm{~K} \text {, } \\
3 \mathrm{Ca}, 2 \mathrm{Ti}, 10 \mathrm{Fe}\end{array}$ \\
\hline 158426-A9(9)_pt1 & 1 & $\mathrm{PM}_{10}$ & Silicates & $\mathrm{O}, \mathrm{Si}, \mathrm{Ca}, \mathrm{Fe}$ & $\begin{array}{l}\mathrm{Na}, \mathrm{Mg}, \mathrm{Al}, \mathrm{P} \\
\mathrm{S}, \mathrm{K}, \mathrm{Ca}, \mathrm{Ti}\end{array}$ & $\begin{array}{l}229 \mathrm{O}, 3 \mathrm{Na}, 5 \mathrm{Mg}, 9 \mathrm{Al}, 78 \mathrm{Si}, 2 \mathrm{P} \\
1 \mathrm{~S}, 1 \mathrm{~K}, 10 \mathrm{Ca}, 1 \mathrm{Ti}, 22 \mathrm{Fe}\end{array}$ \\
\hline 158426-A9(9)_pt4 & 1 & $\mathrm{PM}_{10}$ & Quartz & $\mathrm{Si}, \mathrm{O}$ & $\mathrm{Al}$ & $748 \mathrm{O}, 1 \mathrm{Al}, 373 \mathrm{Si}$ \\
\hline 158426-A9(9)_pt5 & 1 & $\mathrm{PM}_{10}$ & Quartz & $\mathrm{Si}, \mathrm{O}$ & & $2 \mathrm{O}, 1 \mathrm{Si}$ \\
\hline 158426-A9(10)_pt1 & 1 & $\mathrm{PM}_{10}$ & Quartz & $\mathrm{Si}, \mathrm{O}$ & $\mathrm{Na}, \mathrm{Al}$ & $186 \mathrm{O}, 1 \mathrm{Na}, 1 \mathrm{Mg}, 92 \mathrm{Si}$ \\
\hline 158426-A9(11)_pt1 & 1 & $\mathrm{PM}_{10}$ & Silicates & $\mathrm{O}, \mathrm{Si}, \mathrm{Al}, \mathrm{Fe}$ & $\mathrm{Mg}, \mathrm{Cl}, \mathrm{K}, \mathrm{Ca}$ & $\begin{array}{l}339 \mathrm{O}, 4 \mathrm{Mg}, 12 \mathrm{Al}, 58 \mathrm{Si}, 1 \mathrm{Cl}, 1 \mathrm{~K}, 2 \mathrm{Ca} \text {, } \\
133 \mathrm{Fe}\end{array}$ \\
\hline 158426-A9(11)_pt2 & 1 & $\mathrm{PM}_{10}$ & Quartz & $\mathrm{Si}, \mathrm{O}$ & & $2 \mathrm{O}, 1 \mathrm{Si}$ \\
\hline 158426-A9(11)_pt3 & 1 & $\mathrm{PM}_{10}$ & Silicates & $\mathrm{O}, \mathrm{Al}, \mathrm{Si}$ & $\begin{array}{l}\mathrm{Na}, \mathrm{Mg}, \mathrm{K}, \mathrm{Ca} \\
\mathrm{Fe}\end{array}$ & $\begin{array}{l}177 \mathrm{O}, 3 \mathrm{Na}, 2 \mathrm{Mg}, 15 \mathrm{Al}, 72 \mathrm{Si}, 4 \mathrm{~K}, 1 \mathrm{Ca} \text {, } \\
\mathrm{Fe}\end{array}$ \\
\hline
\end{tabular}


Table B4. Particulate matter identification (continued)

\begin{tabular}{|c|c|c|c|c|c|c|}
\hline SEM ID number & $\begin{array}{l}\text { Site } \\
\text { number }\end{array}$ & $\begin{array}{l}\text { Particle } \\
\text { type }\end{array}$ & $\begin{array}{l}\text { Mineral } \\
\text { group }\end{array}$ & $\begin{array}{l}\text { Major } \\
\text { elements }\end{array}$ & $\begin{array}{l}\text { Minor } \\
\text { elements }\end{array}$ & Formulas from SEM data \\
\hline 158426-A9(11)_pt4 & 1 & $\mathrm{PM}_{10}$ & Quartz & $\mathrm{Si}, \mathrm{O}$ & & $2 \mathrm{O}, 1 \mathrm{Si}$ \\
\hline 158426-A9(11)_pt5 & 1 & $\mathrm{PM}_{10}$ & Quartz & $\mathrm{Si}, \mathrm{O}$ & & $2 \mathrm{O}, 1 \mathrm{Si}$ \\
\hline $\begin{array}{l}\text { 158426- } \\
\text { A9(2ndDay)(1)_pt1 }\end{array}$ & 1 & $\mathrm{PM}_{10}$ & Quartz & $\mathrm{Si}, \mathrm{O}$ & $\begin{array}{l}\mathrm{N}, \mathrm{Na}, \mathrm{Al}, \mathrm{S} \\
\mathrm{Cl}, \mathrm{Ca}\end{array}$ & $\begin{array}{l}102 \mathrm{~N}, 1342 \mathrm{O}, 11 \mathrm{Na}, 1 \mathrm{Al}, 532 \mathrm{Si} \\
4 \mathrm{~S}, 4 \mathrm{Cl}, 3 \mathrm{Ca}\end{array}$ \\
\hline $\begin{array}{l}\text { 158426- } \\
\text { A9(2ndDay)(1)_pt2 }\end{array}$ & 1 & $\mathrm{PM}_{10}$ & Silicates & $\mathrm{Si}, \mathrm{Al}, \mathrm{O}$ & $\begin{array}{l}\mathrm{Na}, \mathrm{Mg}, \mathrm{Cl}, \mathrm{K}, \\
\mathrm{Fe}\end{array}$ & $\begin{array}{l}214 \mathrm{O}, 1 \mathrm{Na}, 9 \mathrm{Mg}, 25 \mathrm{Al}, 77 \mathrm{Si}, 1 \mathrm{Cl}, 9 \mathrm{~K} \text {, } \\
\mathrm{Fe}\end{array}$ \\
\hline $\begin{array}{l}\text { 158426- } \\
\text { A9(2ndDay)(3)_pt1 }\end{array}$ & 1 & $\mathrm{PM}_{10}$ & $\begin{array}{l}\text { K- } \\
\text { feldspars }\end{array}$ & $\mathrm{Si}, \mathrm{O}, \mathrm{K}, \mathrm{Al}$ & $\mathrm{C}, \mathrm{Na}$ & $23 \mathrm{C}, 147 \mathrm{O}, 1 \mathrm{Na}, 11 \mathrm{Al}, 40 \mathrm{Si}, 9 \mathrm{~K}$ \\
\hline $\begin{array}{l}\text { 158426- } \\
\text { A9(2ndDay)(4)_pt1 }\end{array}$ & 1 & $\mathrm{PM}_{10}$ & Quartz & $\mathrm{Si}, \mathrm{O}$ & $\mathrm{C}$ & $1 \mathrm{C}, 15 \mathrm{O}, 6 \mathrm{Si}$ \\
\hline $\begin{array}{l}\text { 158426- } \\
\text { A9(2ndDay)(4)_pt2 }\end{array}$ & 1 & $\mathrm{PM}_{10}$ & Quartz & $\mathrm{Si}, \mathrm{O}$ & $\begin{array}{l}\mathrm{Na}, \mathrm{Mg}, \mathrm{Al}, \mathrm{P} \\
\mathrm{K}, \mathrm{Ca}, \mathrm{Ti}, \mathrm{Fe}\end{array}$ & $\begin{array}{l}355 \mathrm{O}, 2 \mathrm{Na}, 4 \mathrm{Mg}, 16 \mathrm{Al}, 148 \mathrm{Si}, 1 \mathrm{P}, 2 \mathrm{~K} \\
10 \mathrm{Ca}, 1 \mathrm{Ti}, 9 \mathrm{Fe}\end{array}$ \\
\hline test158426 A9(2)_pt1 & 1 & $\mathrm{PM}_{10}$ & Quartz & $\mathrm{Si}, \mathrm{O}, \mathrm{C}$ & $\begin{array}{l}\mathrm{C}, \mathrm{Na}, \mathrm{Mg}, \mathrm{Al}, \\
\mathrm{K}, \mathrm{Ca}, \mathrm{Fe}\end{array}$ & $\begin{array}{l}47 \mathrm{C}, 168 \mathrm{O}, 3 \mathrm{Na}, 2 \mathrm{Mg}, 14 \mathrm{Al}, 69 \mathrm{Si}, 2 \mathrm{~K} \text {, } \\
1 \mathrm{Ca}, 3 \mathrm{Fe}\end{array}$ \\
\hline
\end{tabular}


Table B4. Particulate matter identification (continued)

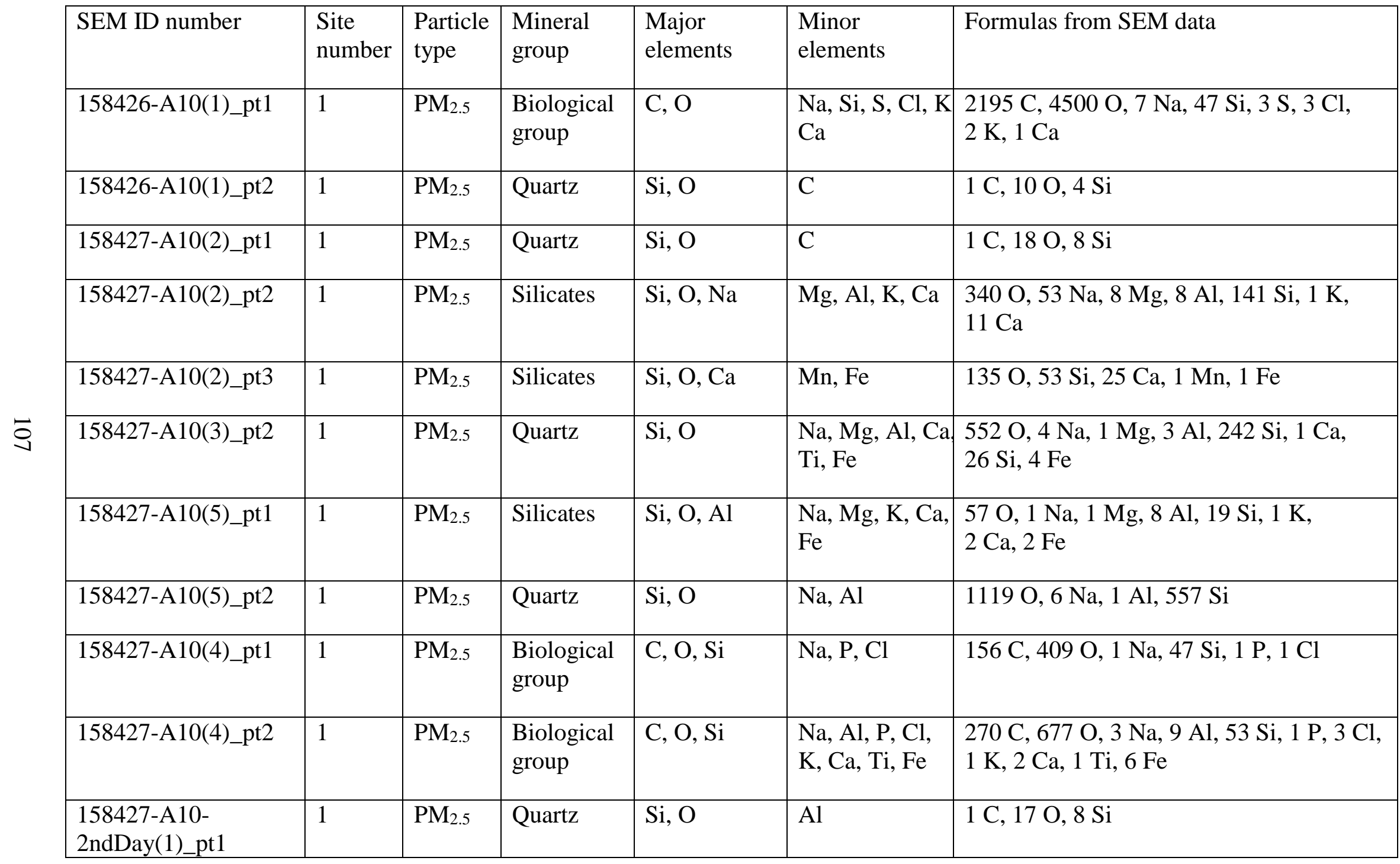


Table B4. Particulate matter identification (continued)

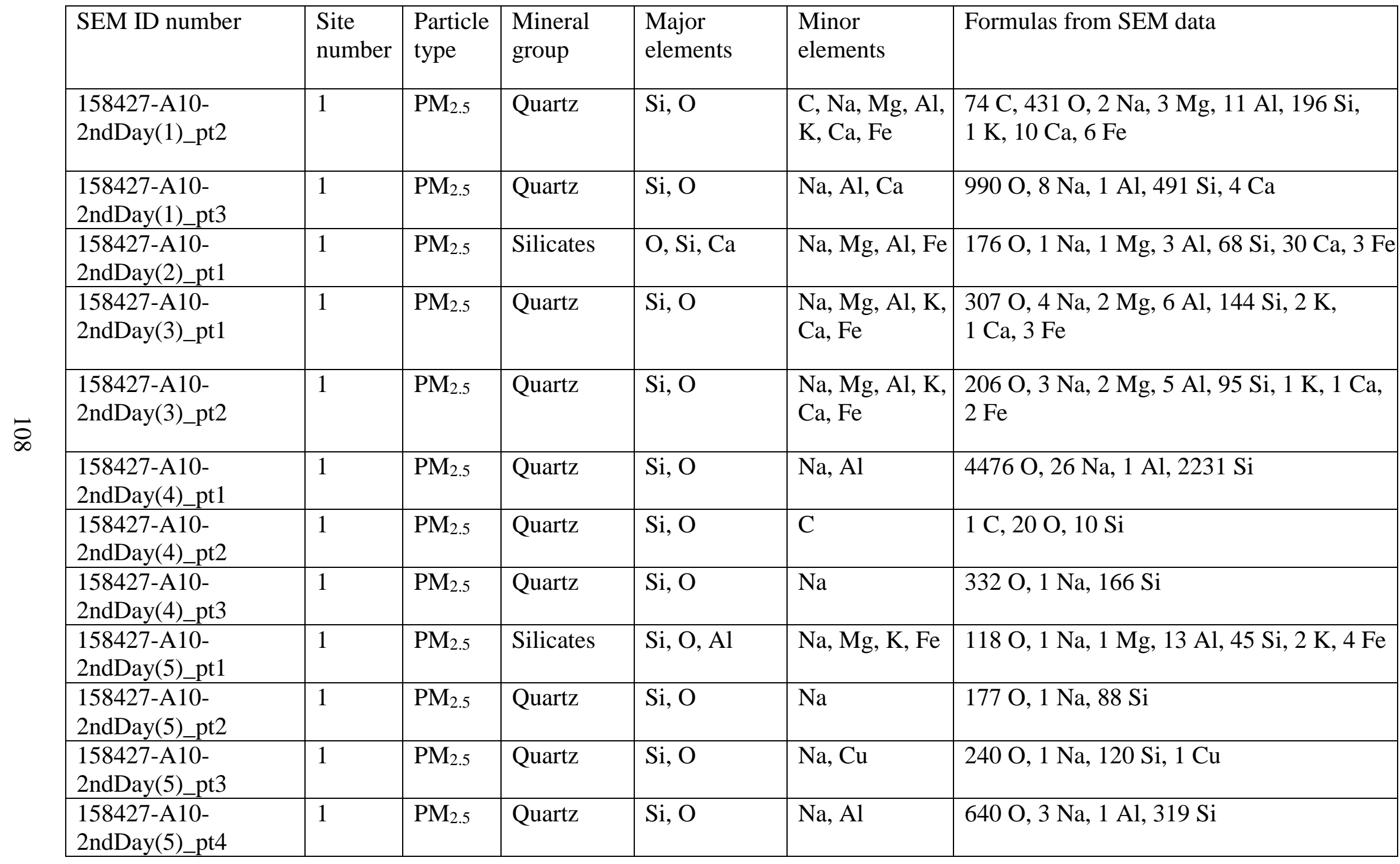


Table B4. Particulate matter identification (continued)

\begin{tabular}{|c|c|c|c|c|c|c|}
\hline SEM ID number & $\begin{array}{l}\text { Site } \\
\text { number }\end{array}$ & $\begin{array}{l}\text { Particle } \\
\text { type }\end{array}$ & $\begin{array}{l}\text { Mineral } \\
\text { group }\end{array}$ & $\begin{array}{l}\text { Major } \\
\text { elements }\end{array}$ & $\begin{array}{l}\text { Minor } \\
\text { elements }\end{array}$ & Formulas from SEM data \\
\hline $\begin{array}{l}\text { 158427-A10- } \\
\text { 2ndDay(6)_pt1 }\end{array}$ & 1 & $\mathrm{PM}_{2.5}$ & Quartz & $\mathrm{Si}, \mathrm{O}$ & $\mathrm{Na}$ & $152 \mathrm{O}, 1 \mathrm{Na}, 76 \mathrm{Si}$ \\
\hline 158427-A10(4)_pt3 & 1 & $\mathrm{PM}_{2.5}$ & Quartz & $\mathrm{Si}, \mathrm{O}$ & $\mathrm{Al}$ & $691 \mathrm{O}, 1 \mathrm{Al}, 345 \mathrm{Si}$ \\
\hline 158427-A10(46)_pt1 & 1 & $\mathrm{PM}_{2.5}$ & Quartz & $\mathrm{Si}, \mathrm{O}$ & $\mathrm{Al}$ & $4490 \mathrm{O}, 1 \mathrm{Al}, 2245 \mathrm{Si}$ \\
\hline $\begin{array}{l}\text { 158427-A10- } \\
\text { 2ndDay(6)_pt3 }\end{array}$ & 1 & $\mathrm{PM}_{2.5}$ & Quartz & $\mathrm{Si}, \mathrm{O}$ & $\mathrm{Na}, \mathrm{P}, \mathrm{Ca}$ & $442 \mathrm{O}, 3 \mathrm{Na}, 217 \mathrm{Si}, 3 \mathrm{P}, 1 \mathrm{Ca}$ \\
\hline $\begin{array}{l}\text { 158427-A14- } \\
\text { 2ndDay(7)_pt1 }\end{array}$ & 2 & $\mathrm{PM}_{10}$ & Quartz & $\mathrm{Si}, \mathrm{O}$ & $\begin{array}{l}\mathrm{Na}, \mathrm{Mg}, \mathrm{Al}, \mathrm{K} \\
\mathrm{Ca}, \mathrm{Fe}\end{array}$ & $\begin{array}{l}179 \mathrm{O}, 2 \mathrm{Na}, 2 \mathrm{Mg}, 7 \mathrm{Al}, 78 \mathrm{Si}, 1 \mathrm{~K}, 4 \mathrm{Ca}, \\
4 \mathrm{Fe}\end{array}$ \\
\hline $\begin{array}{l}\text { 158427-A14- } \\
\text { 2ndDay(7)_pt4 }\end{array}$ & 2 & $\mathrm{PM}_{10}$ & Silicates & $\mathrm{O}, \mathrm{Al}, \mathrm{Si}, \mathrm{Ca}$ & $\mathrm{Na}, \mathrm{Mg}, \mathrm{K}, \mathrm{Mn}$ & $\begin{array}{l}289 \mathrm{O}, 10 \mathrm{Na}, 5 \mathrm{Mg}, 20 \mathrm{Al}, 86 \mathrm{Si}, 1 \mathrm{~K}, \\
50 \mathrm{Ca}, 3 \mathrm{Mn}\end{array}$ \\
\hline $\begin{array}{l}\text { 158427-A14- } \\
\text { 2ndDay(7)_pt5 }\end{array}$ & 2 & $\mathrm{PM}_{10}$ & Silicates & $\mathrm{O}, \mathrm{Si}, \mathrm{Fe}$ & $\begin{array}{l}\mathrm{Na}, \mathrm{Mg}, \mathrm{Al}, \mathrm{K} \\
\mathrm{Ca}\end{array}$ & $\begin{array}{l}231 \mathrm{O}, 2 \mathrm{Na}, 3 \mathrm{Mg}, 17 \mathrm{Al}, 59 \mathrm{Si}, 1 \mathrm{~K}, 5 \mathrm{Ca} \text {, } \\
50 \mathrm{Fe}\end{array}$ \\
\hline $\begin{array}{l}\text { 158427-A14- } \\
\text { 2ndDay(7)_pt6 }\end{array}$ & 2 & $\mathrm{PM}_{10}$ & Quartz & $\mathrm{Si}, \mathrm{O}$ & $\begin{array}{l}\mathrm{Na}, \mathrm{Mg}, \mathrm{Al}, \mathrm{K} \\
\mathrm{Ca}, \mathrm{Fe}\end{array}$ & $\begin{array}{l}410 \mathrm{O}, 3 \mathrm{Na}, 2 \mathrm{Mg}, 10 \mathrm{Al}, 193 \mathrm{Si}, 1 \mathrm{~K}, \\
2 \mathrm{Ca}, 3 \mathrm{Fe}\end{array}$ \\
\hline
\end{tabular}


Table B4. Particulate matter identification (continued)

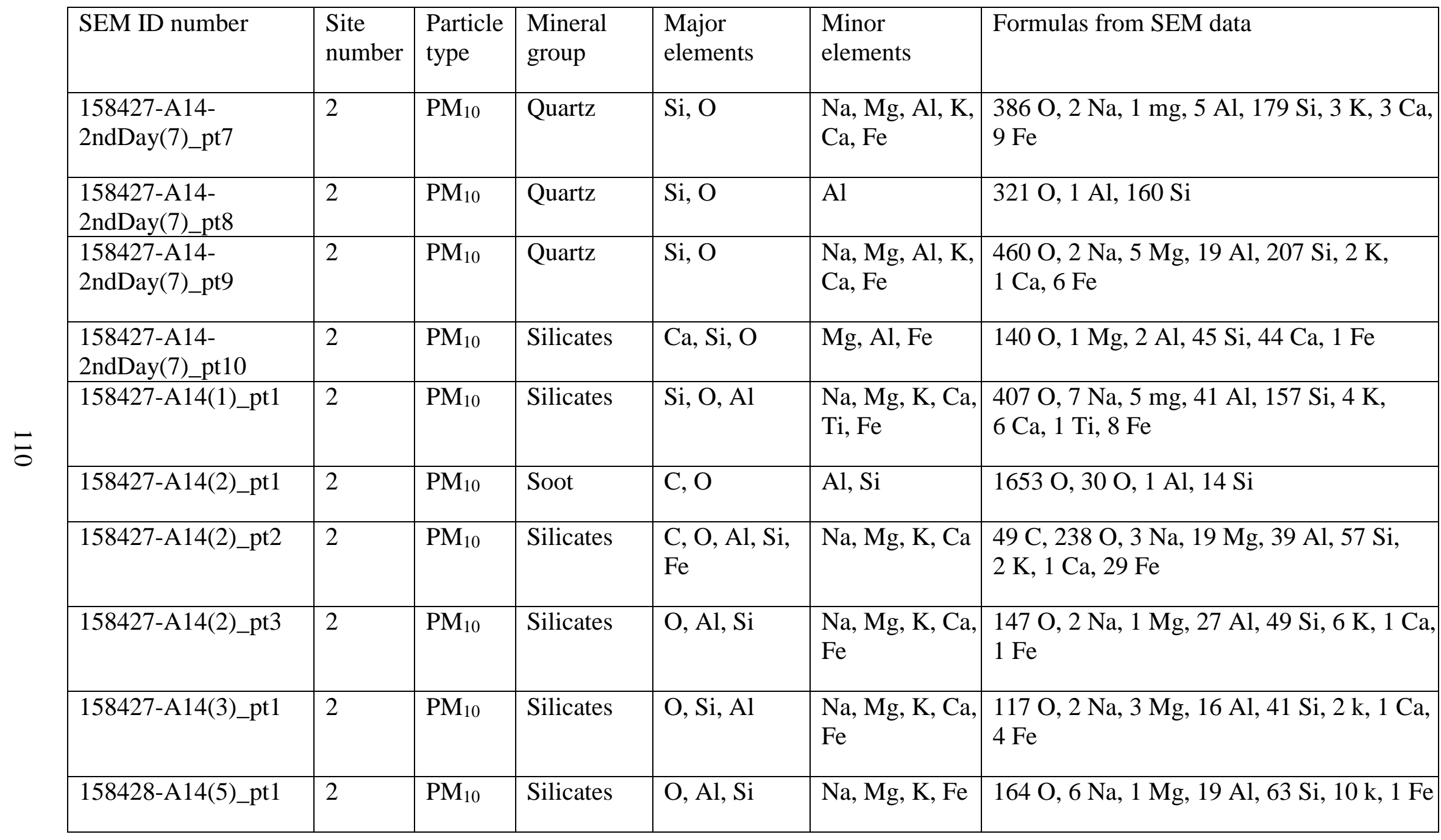


Table B4. Particulate matter identification (continued)

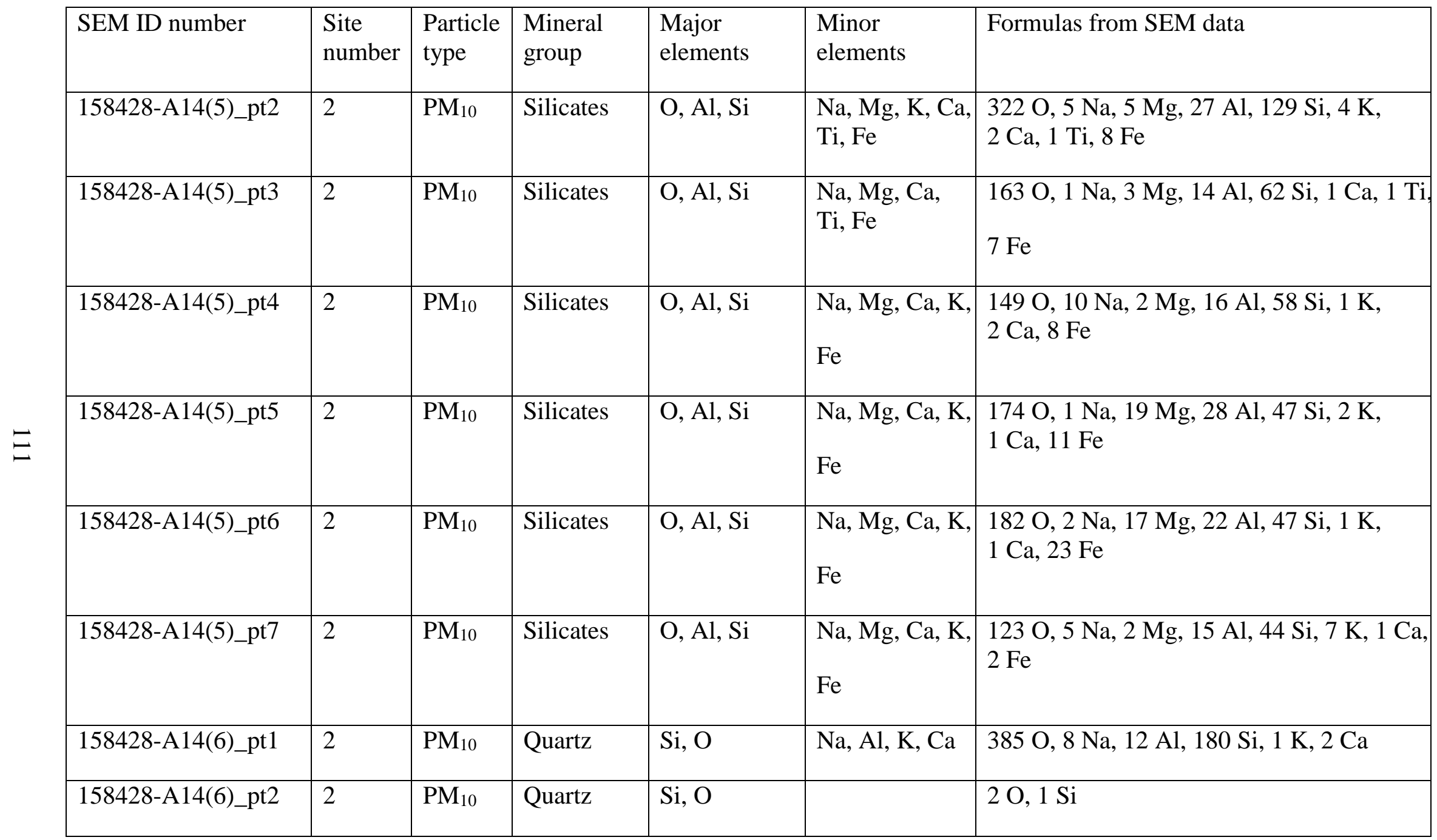


Table B4. Particulate matter identification (continued)

\begin{tabular}{|c|c|c|c|c|c|c|}
\hline SEM ID number & $\begin{array}{l}\text { Site } \\
\text { number }\end{array}$ & $\begin{array}{l}\text { Particle } \\
\text { type }\end{array}$ & $\begin{array}{l}\text { Mineral } \\
\text { group }\end{array}$ & $\begin{array}{l}\text { Major } \\
\text { elements }\end{array}$ & $\begin{array}{l}\text { Minor } \\
\text { elements }\end{array}$ & Formulas from SEM data \\
\hline 158428-A14(6)_pt3 & 2 & $\mathrm{PM}_{10}$ & Quartz & $\mathrm{Si}, \mathrm{O}$ & $\begin{array}{l}\mathrm{Na}, \mathrm{Mg}, \mathrm{Al}, \mathrm{K} \\
\mathrm{Ca}, \mathrm{Ti}, \mathrm{Fe}\end{array}$ & $\begin{array}{l}289 \mathrm{O}, 3 \mathrm{Na}, 3 \mathrm{Mg}, 26 \mathrm{Al}, 116 \mathrm{Si}, 8 \mathrm{~K} \\
2 \mathrm{Ca}, 1 \mathrm{Ti}, 4 \mathrm{Fe}\end{array}$ \\
\hline $\begin{array}{l}\text { 158427-A10- } \\
\text { 2ndDay(7)_pt1 }\end{array}$ & 2 & $\mathrm{PM}_{10}$ & Quartz & $\mathrm{Si}, \mathrm{O}$ & $\begin{array}{l}\mathrm{Na}, \mathrm{Mg}, \mathrm{Al}, \mathrm{K} \\
\mathrm{Ca}, \mathrm{Fe}\end{array}$ & $\begin{array}{l}239 \mathrm{O}, 3 \mathrm{Na}, 3 \mathrm{Mg}, 1 \mathrm{Al}, 104 \mathrm{Si}, 1 \mathrm{~K}, 5 \mathrm{Ca} \text {, } \\
5 \mathrm{Fe}\end{array}$ \\
\hline $\begin{array}{l}\text { 158427-A10- } \\
\text { 2ndDay(7)_pt3 }\end{array}$ & 2 & $\mathrm{PM}_{10}$ & Silicates & $\begin{array}{l}\mathrm{O}, \mathrm{Mg}, \mathrm{Al}, \mathrm{Si}, \\
\mathrm{Fe}\end{array}$ & $\mathrm{Na}, \mathrm{K}, \mathrm{Ca}, \mathrm{Ti}$ & $\begin{array}{l}324 \mathrm{O}, 1 \mathrm{Na}, 34 \mathrm{Mg}, 64 \mathrm{Al}, 76 \mathrm{Si}, 3 \mathrm{~K} \\
1 \mathrm{Ca}, 2 \mathrm{Ti}, 24 \mathrm{Fe}\end{array}$ \\
\hline $\begin{array}{l}\text { 158427-A10- } \\
\text { 2ndDay(7)_pt4 }\end{array}$ & 2 & $\mathrm{PM}_{10}$ & Silicates & $\mathrm{O}, \mathrm{Al}, \mathrm{Si}, \mathrm{Ca}$ & $\begin{array}{l}\mathrm{Na}, \mathrm{Mg}, \mathrm{K}, \mathrm{Ti} \\
\mathrm{Fe}\end{array}$ & $\begin{array}{l}289 \mathrm{O}, 10 \mathrm{Na}, 5 \mathrm{Mg}, 20 \mathrm{Al}, 86 \mathrm{Si}, 1 \mathrm{~K}, \\
50 \mathrm{Ca}, 3 \mathrm{Ti}, 13 \mathrm{Fe}\end{array}$ \\
\hline $\begin{array}{l}\text { 158427-A10- } \\
\text { 2ndDay(7)_pt6 }\end{array}$ & 2 & $\mathrm{PM}_{10}$ & Quartz & $\mathrm{Si}, \mathrm{O}$ & $\begin{array}{l}\mathrm{Na}, \mathrm{Mg}, \mathrm{Al}, \mathrm{K} \\
\mathrm{Ca}, \mathrm{Fe}\end{array}$ & $\begin{array}{l}410 \mathrm{O}, 3 \mathrm{Na}, 2 \mathrm{Mg}, 10 \mathrm{Al}, 193 \mathrm{Si}, 1 \mathrm{~K}, \\
2 \mathrm{Ca}, 3 \mathrm{Fe}\end{array}$ \\
\hline $\begin{array}{l}\text { 158427-A10- } \\
\text { 2ndDay(7)_pt7 }\end{array}$ & 2 & $\mathrm{PM}_{10}$ & Quartz & $\mathrm{Si}, \mathrm{O}$ & $\begin{array}{l}\mathrm{Na}, \mathrm{Mg}, \mathrm{Al}, \mathrm{K} \\
\mathrm{Ca}, \mathrm{Fe}\end{array}$ & $\begin{array}{l}386 \mathrm{O}, 2 \mathrm{Na}, 1 \mathrm{Mg}, 5 \mathrm{Al}, 179 \mathrm{Si}, 3 \mathrm{~K}, 3 \mathrm{Ca} \text {, } \\
9 \mathrm{Fe}\end{array}$ \\
\hline $\begin{array}{l}\text { 158427-A10- } \\
\text { 2ndDay(7)_pt8 }\end{array}$ & 2 & $\mathrm{PM}_{10}$ & Quartz & $\mathrm{Si}, \mathrm{O}$ & $\mathrm{Al}$ & $321 \mathrm{O}, 1 \mathrm{Al}, 160 \mathrm{Si}$ \\
\hline
\end{tabular}


Table B4. Particulate matter identification (continued)

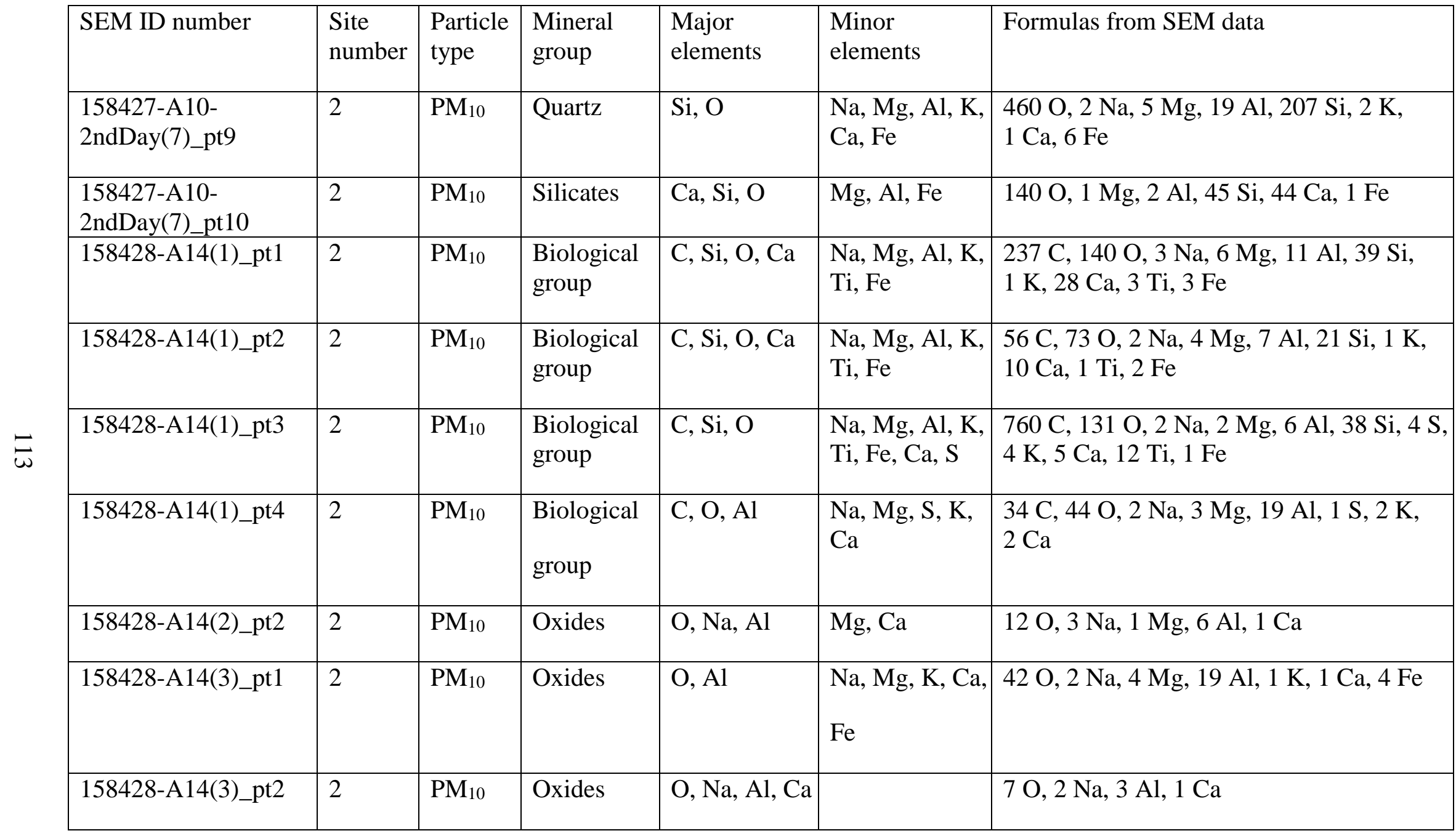


Table B4. Particulate matter identification (continued)

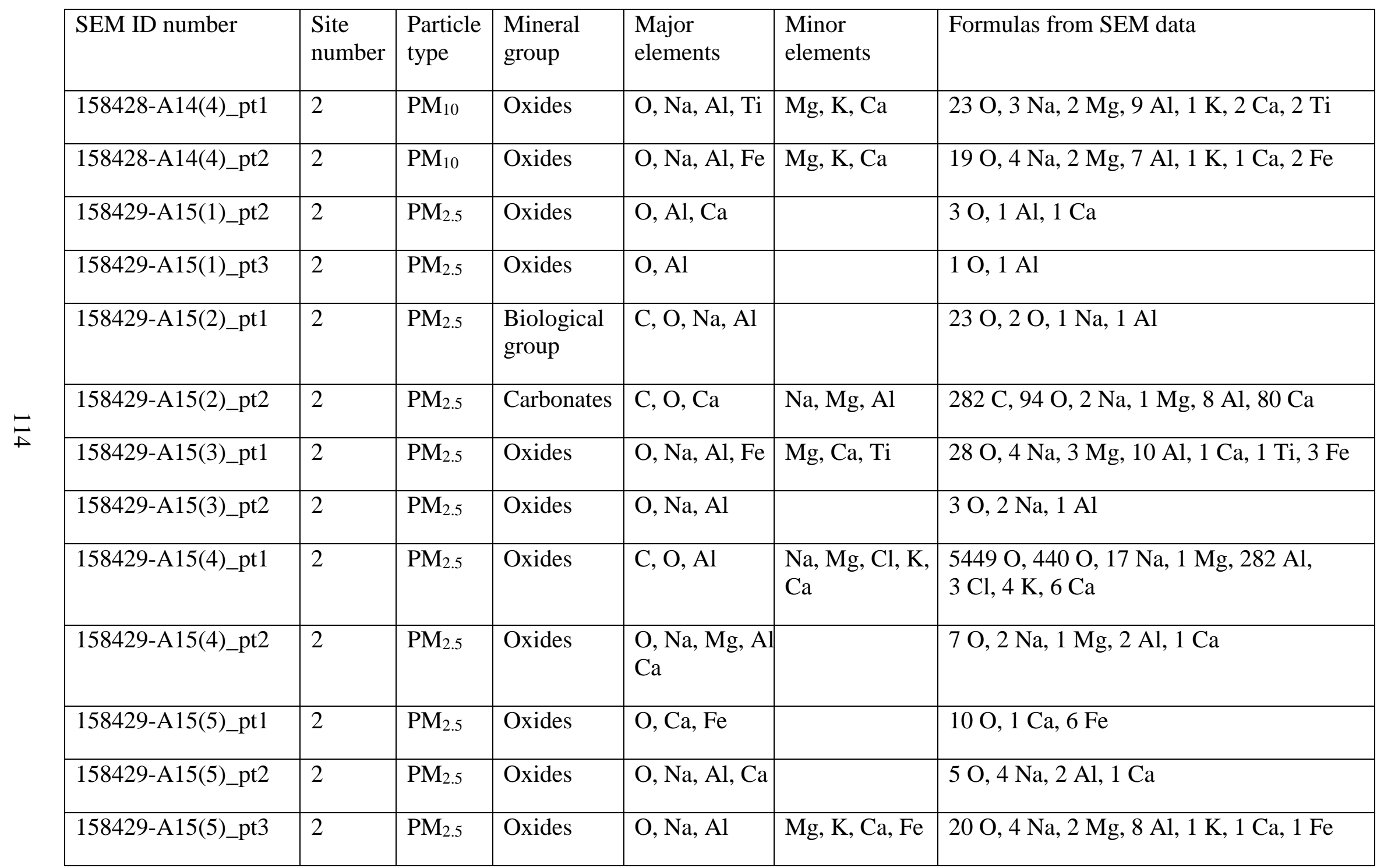


Table B4. Particulate matter identification (continued)

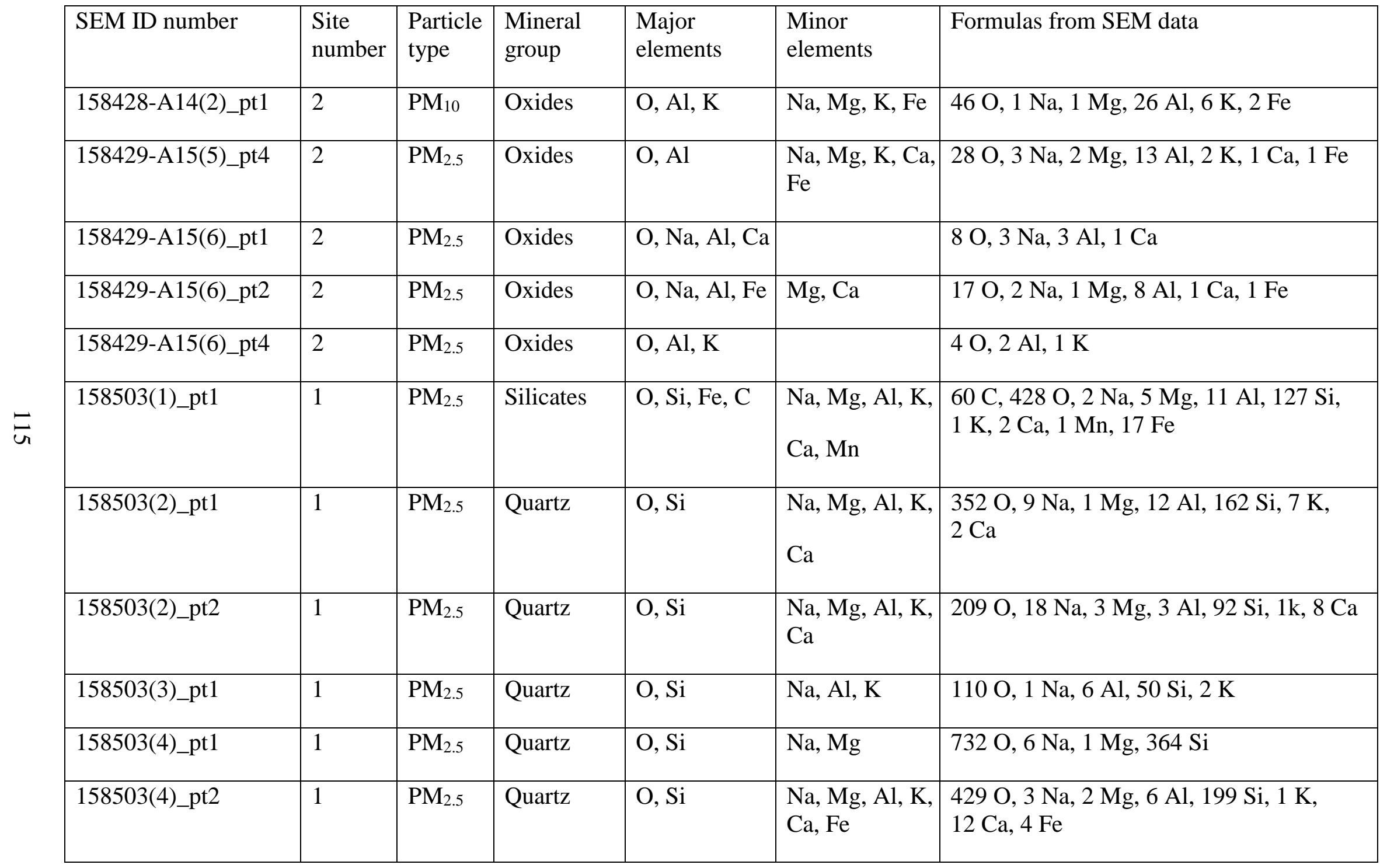


Table B4. Particulate matter identification (continued)

\begin{tabular}{|c|c|c|c|c|c|c|}
\hline SEM ID number & $\begin{array}{l}\text { Site } \\
\text { number }\end{array}$ & $\begin{array}{l}\text { Particle } \\
\text { type }\end{array}$ & $\begin{array}{l}\text { Mineral } \\
\text { group }\end{array}$ & $\begin{array}{l}\text { Major } \\
\text { elements }\end{array}$ & $\begin{array}{l}\text { Minor } \\
\text { elements }\end{array}$ & Formulas from SEM data \\
\hline 158503(4)_pt3 & 1 & $\mathrm{PM}_{2.5}$ & Quartz & $\mathrm{O}, \mathrm{Si}$ & $\mathrm{Na}, \mathrm{Al}$ & $190 \mathrm{O}, 1 \mathrm{Na}, 1 \mathrm{Mg}, 94 \mathrm{Si}$ \\
\hline 158503(4)_pt4 & 1 & $\mathrm{PM}_{2.5}$ & Quartz & $\mathrm{O}, \mathrm{Si}$ & $\begin{array}{l}\mathrm{Mg}, \mathrm{Al}, \mathrm{S}, \mathrm{K} \\
\mathrm{Ca}, \mathrm{Fe}\end{array}$ & $\begin{array}{l}556 \mathrm{O}, 3 \mathrm{Mg}, 8 \mathrm{Al}, 262 \mathrm{Si}, 3 \mathrm{~S}, 1 \mathrm{~K}, 1 \mathrm{Ca}, \\
5 \mathrm{Fe}\end{array}$ \\
\hline 158503(4)_pt5 & 1 & $\mathrm{PM}_{2.5}$ & Quartz & $\mathrm{O}, \mathrm{Si}$ & $\mathrm{Na}$ & $254 \mathrm{O}, 1 \mathrm{Na}, 127 \mathrm{Si}$ \\
\hline 158503(4)_pt6 & 1 & $\mathrm{PM}_{2.5}$ & Quartz & $\mathrm{O}, \mathrm{Si}$ & $\mathrm{Na}, \mathrm{Mg}, \mathrm{Al}, \mathrm{Ca}$ & $610 \mathrm{O}, 5 \mathrm{Na}, 2 \mathrm{Mg}, 1 \mathrm{Al}, 286 \mathrm{Si}, 32 \mathrm{Ca}$ \\
\hline 158503(5)_pt1 & 1 & $\mathrm{PM}_{2.5}$ & Quartz & $\mathrm{O}, \mathrm{Si}$ & $\begin{array}{l}\mathrm{Na}, \mathrm{Mg}, \mathrm{Al}, \mathrm{K}, \\
\mathrm{Ca}, \mathrm{Fe}\end{array}$ & $\begin{array}{l}301 \mathrm{O}, 4 \mathrm{Na}, 1 \mathrm{Mg}, 9 \mathrm{Al}, 139 \mathrm{Si}, 1 \mathrm{~K}, 2 \mathrm{Ca} \text {, } \\
2 \mathrm{Fe}\end{array}$ \\
\hline 158503(5)_pt3 & 1 & $\mathrm{PM}_{2.5}$ & Quartz & $\mathrm{O}, \mathrm{Si}$ & & $2 \mathrm{O}, 1 \mathrm{Si}$ \\
\hline 158503(5)_pt4 & 1 & $\mathrm{PM}_{2.5}$ & Silicates & $\mathrm{O}, \mathrm{Si}, \mathrm{Mg}, \mathrm{Al}$ & $\mathrm{Na}, \mathrm{K}, \mathrm{Ca}, \mathrm{Fe}$ & $\begin{array}{l}306 \mathrm{O}, 1 \mathrm{Na}, 14 \mathrm{Mg}, 17 \mathrm{Al}, 123 \mathrm{Si}, 3 \mathrm{~K} \\
5 \mathrm{Ca}, 9 \mathrm{Fe}\end{array}$ \\
\hline 158503(5)_pt5 & 1 & $\mathrm{PM}_{2.5}$ & Quartz & $\mathrm{O}, \mathrm{Si}$ & $\mathrm{Na}, \mathrm{Al}, \mathrm{K}$ & $563 \mathrm{O}, 2 \mathrm{Na}, 4 \mathrm{Al}, 278 \mathrm{Si}, 1 \mathrm{~K}$ \\
\hline 158503(5)_pt6 & 1 & $\mathrm{PM}_{2.5}$ & Silicates & $\mathrm{O}, \mathrm{Si}, \mathrm{Fe}$ & $\mathrm{Na}, \mathrm{Mg}, \mathrm{Al}, \mathrm{Ca}$ & $\begin{array}{l}448 \mathrm{O}, 3 \mathrm{Na}, 1 \mathrm{Mg}, 4 \mathrm{Al}, 204 \mathrm{Si}, 1 \mathrm{Ca} \\
21 \mathrm{Fe}\end{array}$ \\
\hline 158503(5)_pt7 & 1 & $\mathrm{PM}_{2.5}$ & Quartz & $\mathrm{O}, \mathrm{Si}$ & $\begin{array}{l}\mathrm{Na}, \mathrm{Mg}, \mathrm{Al}, \mathrm{K}, \\
\mathrm{Ca}, \mathrm{Fe}\end{array}$ & $\begin{array}{l}263 \mathrm{O}, 3 \mathrm{Na}, 2 \mathrm{Mg}, 9 \mathrm{Al}, 120 \mathrm{Si}, 1 \mathrm{~K}, 1 \mathrm{Ca} \text {, } \\
2 \mathrm{Fe}\end{array}$ \\
\hline
\end{tabular}


Table B4. Particulate matter identification (continued)

\begin{tabular}{|c|c|c|c|c|c|c|}
\hline SEM ID number & $\begin{array}{l}\text { Site } \\
\text { number }\end{array}$ & $\begin{array}{l}\text { Particle } \\
\text { type }\end{array}$ & $\begin{array}{l}\text { Mineral } \\
\text { group }\end{array}$ & $\begin{array}{l}\text { Major } \\
\text { elements }\end{array}$ & $\begin{array}{l}\text { Minor } \\
\text { elements }\end{array}$ & Formulas from SEM data \\
\hline 158504(1)_pt1 & 1 & $\mathrm{PM}_{2.5}$ & Quartz & $\mathrm{O}, \mathrm{Si}$ & $\begin{array}{l}\mathrm{Na}, \mathrm{Mg}, \mathrm{Al}, \mathrm{K}, \\
\mathrm{Fe}\end{array}$ & $230 \mathrm{O}, 1 \mathrm{Na}, 1 \mathrm{Mg}, 7 \mathrm{Al}, 106 \mathrm{Si}, 2 \mathrm{~K}, 3 \mathrm{Fe}$ \\
\hline 158504(1)_pt2 & 1 & $\mathrm{PM}_{2.5}$ & Silicates & $\mathrm{O}, \mathrm{Si}, \mathrm{Ca}$ & $\mathrm{Na}, \mathrm{Mg}, \mathrm{Al}, \mathrm{Fe}$ & $\begin{array}{l}386 \mathrm{O}, 1 \mathrm{Na}, 1 \mathrm{Mg}, 1 \mathrm{Al}, 182 \mathrm{Si}, 12 \mathrm{Ca} \\
4 \mathrm{Fe}\end{array}$ \\
\hline 158504(1)_pt3 & 1 & $\mathrm{PM}_{2.5}$ & Silicates & $\mathrm{O}, \mathrm{Si}, \mathrm{Al}$ & $\begin{array}{l}\mathrm{Na}, \mathrm{Mg}, \mathrm{S}, \mathrm{K}, \\
\mathrm{Fe}\end{array}$ & $278 \mathrm{O}, 1 \mathrm{Na}, 8 \mathrm{Mg}, 103 \mathrm{Si}, 1 \mathrm{~S}, 2 \mathrm{~K}, 7 \mathrm{Fe}$ \\
\hline 158504(1)_pt4 & 1 & $\mathrm{PM}_{2.5}$ & Silicates & $\begin{array}{l}\mathrm{O}, \mathrm{C}, \mathrm{Si}, \mathrm{Mg}, \\
\mathrm{Ca}\end{array}$ & $\begin{array}{l}\mathrm{Na}, \mathrm{Al}, \mathrm{S}, \mathrm{K}, \\
\mathrm{Fe}\end{array}$ & $\begin{array}{l}209 \mathrm{C}, 869 \mathrm{O}, 3 \mathrm{Na}, 35 \mathrm{Mg}, 6 \mathrm{Al}, 172 \mathrm{Si}, 1 \\
2 \mathrm{~K}, 50 \mathrm{Ca}, 4 \mathrm{Fe}\end{array}$ \\
\hline 158504(2)_pt3 & 1 & $\mathrm{PM}_{2.5}$ & Quartz & $\mathrm{O}, \mathrm{Si}$ & $\mathrm{Na}, \mathrm{Al}, \mathrm{K}$ & $685 \mathrm{O}, 8 \mathrm{Na}, 1 \mathrm{Al}, 340 \mathrm{Si}, 1 \mathrm{~K}$ \\
\hline 158504(3)_pt1 & 1 & $\mathrm{PM}_{2.5}$ & Silicates & $\mathrm{O}, \mathrm{Si}, \mathrm{Ca}$ & $\begin{array}{l}\mathrm{Na}, \mathrm{Mg}, \mathrm{Al}, \mathrm{S}, \\
\mathrm{Fe}\end{array}$ & $\begin{array}{l}154 \mathrm{O}, 1 \mathrm{Na}, 8 \mathrm{Mg}, 2 \mathrm{Al}, 63 \mathrm{Si}, 1 \mathrm{~S}, 13 \mathrm{Ca} \text {, } \\
1 \mathrm{Fe}\end{array}$ \\
\hline 158504(3)_pt2 & 1 & $\mathrm{PM}_{2.5}$ & Quartz & $\mathrm{O}, \mathrm{Si}$ & $\begin{array}{l}\mathrm{Na}, \mathrm{Al}, \mathrm{S}, \mathrm{K} \\
\mathrm{Ca}\end{array}$ & $275 \mathrm{O}, 3 \mathrm{Na}, 5 \mathrm{Al}, 129 \mathrm{Si}, 1 \mathrm{~S}, 2 \mathrm{~K}, 2 \mathrm{Ca}$ \\
\hline
\end{tabular}


Table B4. Particulate matter identification (continued)

\begin{tabular}{|c|c|c|c|c|c|c|}
\hline SEM ID number & $\begin{array}{l}\text { Site } \\
\text { number }\end{array}$ & $\begin{array}{l}\text { Particle } \\
\text { type }\end{array}$ & $\begin{array}{l}\text { Mineral } \\
\text { group }\end{array}$ & $\begin{array}{l}\text { Major } \\
\text { elements }\end{array}$ & $\begin{array}{l}\text { Minor } \\
\text { elements }\end{array}$ & Formulas from SEM data \\
\hline 158504(3)_pt3 & 1 & $\mathrm{PM}_{2.5}$ & Silicates & $\mathrm{O}, \mathrm{Si}$ & $\begin{array}{l}\mathrm{Na}, \mathrm{Mg}, \mathrm{Al}, \mathrm{S} \\
\mathrm{K}, \mathrm{Ca}, \mathrm{Fe}\end{array}$ & $\begin{array}{l}615 \mathrm{O}, 6 \mathrm{Na}, 7 \mathrm{Mg}, 14 \mathrm{Al}, 270 \mathrm{Si}, 3 \mathrm{~S}, 1 \mathrm{~K} \text {, } \\
3 \mathrm{Ca}, 21 \mathrm{Fe}\end{array}$ \\
\hline 158504(3)_pt4 & 1 & $\mathrm{PM}_{2.5}$ & Silicates & $\begin{array}{l}\mathrm{O}, \mathrm{Si}, \mathrm{Al}, \mathrm{Mg}, \\
\mathrm{Ca}\end{array}$ & $\mathrm{Na}, \mathrm{K}, \mathrm{Ti}, \mathrm{Fe}$ & $\begin{array}{l}427 \mathrm{O}, 3 \mathrm{Na}, 19 \mathrm{Mg}, 10 \mathrm{Al}, 1 \mathrm{~K}, 17 \mathrm{Ca} \\
2 \mathrm{Ti}, 9 \mathrm{Fe}\end{array}$ \\
\hline 158504(3)_pt5 & 1 & $\mathrm{PM}_{2.5}$ & Quartz & $\mathrm{O}, \mathrm{Si}$ & & $2 \mathrm{O}, 1 \mathrm{Si}$ \\
\hline 158504(3)_pt6 & 1 & $\mathrm{PM}_{2.5}$ & Quartz & $\mathrm{O}, \mathrm{Si}$ & & $2 \mathrm{O}, 1 \mathrm{Si}$ \\
\hline 158504(3)_pt7 & 1 & $\mathrm{PM}_{2.5}$ & Quartz & $\mathrm{O}, \mathrm{Si}$ & $\mathrm{Na}, \mathrm{Mg}$ & $671 \mathrm{O}, 5 \mathrm{Na}, 1 \mathrm{Mg}, 334 \mathrm{Si}$ \\
\hline 158504(3)_pt9 & 1 & $\mathrm{PM}_{2.5}$ & Silicates & $\mathrm{O}, \mathrm{Si}, \mathrm{Na}, \mathrm{Al}$ & $\mathrm{Mg}, \mathrm{K}, \mathrm{Fe}$ & $\begin{array}{l}502 \mathrm{O}, 21 \mathrm{Na}, 2 \mathrm{Mg}, 18 \mathrm{Al}, 230 \mathrm{Si}, 1 \mathrm{~K} \\
2 \mathrm{Fe}\end{array}$ \\
\hline 158504(3)_pt10 & 1 & $\mathrm{PM}_{2.5}$ & Quartz & $\mathrm{O}, \mathrm{Si}$ & $\mathrm{Na}$ & $186 \mathrm{O}, 1 \mathrm{Na}, 93 \mathrm{Si}$ \\
\hline $\begin{array}{l}158507 \mathrm{~A}-27 \\
(\mathrm{~A})(1) \_\mathrm{pt} 1\end{array}$ & 1 & $\mathrm{PM}_{10}$ & Silicates & $\mathrm{C}, \mathrm{O}, \mathrm{Si}, \mathrm{Ca}$ & $\mathrm{Na}, \mathrm{Mg}, \mathrm{Al}, \mathrm{Fe}$ & $\begin{array}{l}289 \mathrm{C}, 234 \mathrm{O}, 2 \mathrm{Na}, 1 \mathrm{Mg}, 2 \mathrm{Al}, 71 \mathrm{Si} \\
85 \mathrm{Ca}, 1 \mathrm{Fe}\end{array}$ \\
\hline $\begin{array}{l}158507 \text { A-27 } \\
\text { (A)(1)_pt2 }\end{array}$ & 1 & $\mathrm{PM}_{10}$ & Silicates & $\mathrm{C}, \mathrm{Si}, \mathrm{O}, \mathrm{Al}$ & $\begin{array}{l}\mathrm{Na}, \mathrm{Mg}, \mathrm{K}, \mathrm{Ca} \text {, } \\
\mathrm{Ti}, \mathrm{Fe}\end{array}$ & $\begin{array}{l}132 \mathrm{C}, 554 \mathrm{O}, 4 \mathrm{Na}, 12 \mathrm{Mg}, 31 \mathrm{Al}, 235 \mathrm{Si} \\
2 \mathrm{~K}, 3 \mathrm{Ca}, 1 \mathrm{Ti}, 11 \mathrm{Fe}\end{array}$ \\
\hline
\end{tabular}


Table B4. Particulate matter identification (continued)

\begin{tabular}{|c|c|c|c|c|c|c|}
\hline SEM ID number & $\begin{array}{l}\text { Site } \\
\text { number }\end{array}$ & $\begin{array}{l}\text { Particle } \\
\text { type }\end{array}$ & $\begin{array}{l}\text { Mineral } \\
\text { group }\end{array}$ & $\begin{array}{l}\text { Major } \\
\text { elements }\end{array}$ & $\begin{array}{l}\text { Minor } \\
\text { elements }\end{array}$ & Formulas from SEM data \\
\hline $\begin{array}{l}158507 \text { A-27 } \\
\text { (A)(1)_pt3 }\end{array}$ & 1 & $\mathrm{PM}_{10}$ & Silicates & $\mathrm{C}, \mathrm{O}, \mathrm{Si}, \mathrm{Al}$ & $\mathrm{Na}, \mathrm{Mg}, \mathrm{K}, \mathrm{Fe}$ & $\begin{array}{l}11 \mathrm{C}, 71 \mathrm{O}, 1 \mathrm{Na}, 2 \mathrm{Mg}, 6 \mathrm{Al}, 27 \mathrm{Si}, 1 \mathrm{~K} \\
1 \mathrm{Fe}\end{array}$ \\
\hline $\begin{array}{l}158507 \mathrm{~A}-27 \\
(\mathrm{~A})(1) \_\mathrm{pt} 4\end{array}$ & 1 & $\mathrm{PM}_{10}$ & Silicates & $\begin{array}{l}\mathrm{C}, \mathrm{O}, \mathrm{Si}, \mathrm{Mg}, \\
\mathrm{Fe}\end{array}$ & $\begin{array}{l}\mathrm{Na}, \mathrm{P}, \mathrm{Cl}, \mathrm{K}, \\
\mathrm{Ca}, \mathrm{Ti}\end{array}$ & $\begin{array}{l}453 \mathrm{C}, 633 \mathrm{Si}, 5 \mathrm{Na}, 51 \mathrm{Mg}, 71 \mathrm{Al}, 183 \mathrm{Si}, \\
1 \mathrm{P}, 1 \mathrm{Cl}, 15 \mathrm{~K}, 9 \mathrm{Ca}, 4 \mathrm{Ti}, 53 \mathrm{Fe}\end{array}$ \\
\hline $\begin{array}{l}158509 \mathrm{~A}-27 \\
(\mathrm{C})(1) \_\mathrm{pt} 1\end{array}$ & 1 & $\mathrm{PM}_{10}$ & Silicates & $\begin{array}{l}\mathrm{C}, \mathrm{O}, \mathrm{Mg}, \mathrm{Si}, \\
\mathrm{Ca}\end{array}$ & $\mathrm{Na}, \mathrm{Al}, \mathrm{Fe}$ & $\begin{array}{l}217 \mathrm{C}, 105 \mathrm{O}, 1 \mathrm{Na}, 20 \mathrm{Mg}, 1 \mathrm{Al}, 26 \mathrm{Si}, 26 \\
3 \mathrm{Fe}\end{array}$ \\
\hline $\begin{array}{l}158509 \text { A-27 } \\
\text { (C)(1)_pt2 }\end{array}$ & 1 & $\mathrm{PM}_{10}$ & Silicates & $\mathrm{C}, \mathrm{O}, \mathrm{Si}$ & $\mathrm{Na}, \mathrm{Al}, \mathrm{K}, \mathrm{Ca}$ & $\begin{array}{l}101 \mathrm{C}, 540 \mathrm{O}, 35 \mathrm{Na}, 51 \mathrm{Al}, 218 \mathrm{Si}, 1 \mathrm{~K}, \\
11 \mathrm{Ca}\end{array}$ \\
\hline $\begin{array}{l}158509 \mathrm{~A}-27 \\
(\mathrm{C})(1) \_\mathrm{pt} 4\end{array}$ & 1 & $\mathrm{PM}_{10}$ & Silicates & $\mathrm{C}, \mathrm{O}, \mathrm{Si}$ & $\begin{array}{l}\mathrm{Na}, \mathrm{Mg}, \mathrm{Al}, \mathrm{K}, \\
\mathrm{Ca}, \mathrm{Fe}\end{array}$ & $\begin{array}{l}360 \mathrm{C}, 523 \mathrm{O}, 2 \mathrm{Na}, 3 \mathrm{Mg}, 10 \mathrm{Al}, 244 \mathrm{Si} \\
1 \mathrm{~K}, 7 \mathrm{Ca}, 6 \mathrm{Fe}\end{array}$ \\
\hline $\begin{array}{l}158510 \mathrm{~A}-27 \\
\text { (D)(1)_pt1 }\end{array}$ & 1 & $\mathrm{PM}_{10}$ & Silicates & $\mathrm{C}, \mathrm{O}, \mathrm{Si}, \mathrm{Al}$ & $\begin{array}{l}\mathrm{Na}, \mathrm{Mg}, \mathrm{K}, \mathrm{Ca}, \\
\mathrm{Ti}, \mathrm{Fe}\end{array}$ & $\begin{array}{l}69 \mathrm{C}, 384 \mathrm{O}, 5 \mathrm{Na}, 5 \mathrm{Mg}, 33 \mathrm{Al}, 152 \mathrm{Si} \\
5 \mathrm{~K}, 1 \mathrm{Ca}, 1 \mathrm{Ti}, 11 \mathrm{Fe}\end{array}$ \\
\hline
\end{tabular}


Table B4. Particulate matter identification (continued)

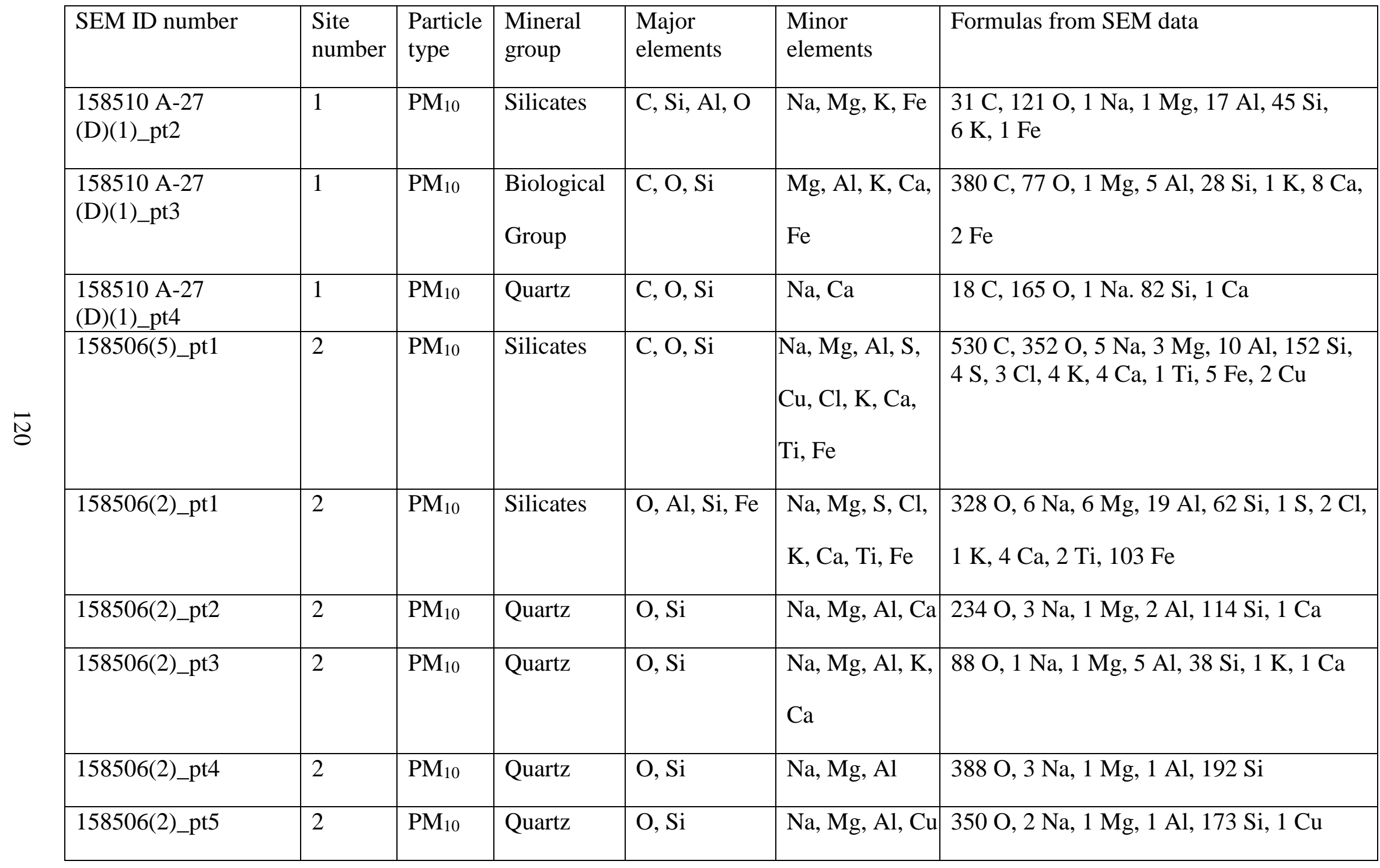


Table B4. Particulate matter identification (continued)

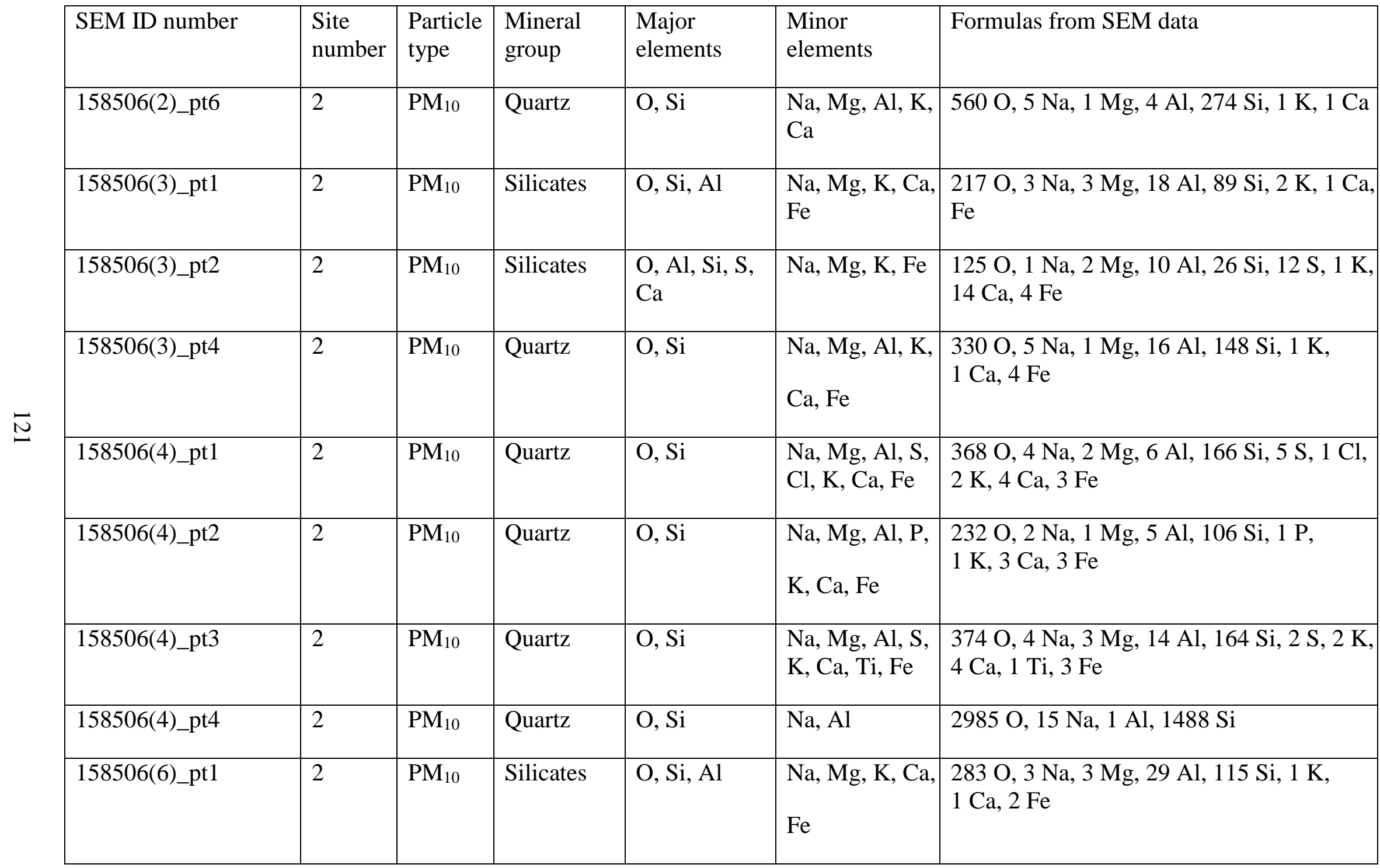


Table B4. Particulate matter identification (continued)

\begin{tabular}{|c|c|c|c|c|c|c|}
\hline SEM ID number & $\begin{array}{l}\text { Site } \\
\text { number }\end{array}$ & $\begin{array}{l}\text { Particle } \\
\text { type }\end{array}$ & $\begin{array}{l}\text { Mineral } \\
\text { group }\end{array}$ & $\begin{array}{l}\text { Major } \\
\text { elements }\end{array}$ & $\begin{array}{l}\text { Minor } \\
\text { elements }\end{array}$ & Formulas from SEM data \\
\hline 158506(6)_pt2 & 2 & $\mathrm{PM}_{10}$ & Silicates & $\mathrm{O}, \mathrm{Si}, \mathrm{Al}$ & $\begin{array}{l}\mathrm{Na}, \mathrm{Mg}, \mathrm{K}, \mathrm{Ca}, \\
\mathrm{Fe}\end{array}$ & $\begin{array}{l}93 \mathrm{O}, 2 \mathrm{Na}, 1 \mathrm{Mg}, 8 \mathrm{Al}, 37 \mathrm{Si}, 2 \mathrm{~K}, 1 \mathrm{Ca} \text {, } \\
1 \mathrm{Fe}\end{array}$ \\
\hline 158506(6)_pt3 & 2 & $\mathrm{PM}_{10}$ & Quartz & $\mathrm{O}, \mathrm{Si}$ & $\begin{array}{l}\mathrm{Na}, \mathrm{Mg}, \mathrm{Al}, \mathrm{K}, \\
\mathrm{Ca}\end{array}$ & $\begin{array}{l}574 \mathrm{O}, 5 \mathrm{Na}, 2 \mathrm{Mg}, 5 \mathrm{Al}, 281 \mathrm{Si}, 1 \mathrm{~K}, \\
1 \mathrm{Ca}\end{array}$ \\
\hline 158506(6)_pt4 & 2 & $\mathrm{PM}_{10}$ & Quartz & $\mathrm{O}, \mathrm{Si}$ & $\mathrm{Al}$ & $374 \mathrm{O}, 1 \mathrm{Al}, 186 \mathrm{Si}$ \\
\hline 158506(7)_pt1 & 2 & $\mathrm{PM}_{10}$ & Quartz & $\mathrm{O}, \mathrm{Si}$ & $\begin{array}{l}\mathrm{Na}, \mathrm{Mg}, \mathrm{Al}, \mathrm{K}, \\
\mathrm{Ca}, \mathrm{Fe}\end{array}$ & $\begin{array}{l}370 \mathrm{O}, 6 \mathrm{Na}, 3 \mathrm{Mg}, 13 \mathrm{Al}, 170 \mathrm{Si}, 1 \mathrm{~K} \\
4 \mathrm{Ca}, 2 \mathrm{Fe}\end{array}$ \\
\hline 6-8-15(1)_pt2 & 2 & $\mathrm{PM}_{10}$ & Quartz & $\mathrm{O}, \mathrm{Si}$ & $\mathrm{Al}, \mathrm{Ca}$ & $211 \mathrm{O}, 1 \mathrm{Al}, 103 \mathrm{Si}, 4 \mathrm{Ca}$ \\
\hline 158515(1)_pt1 & 2 & $\mathrm{PM}_{2.5}$ & Quartz & $\mathrm{O}, \mathrm{Si}$ & $\mathrm{Na}, \mathrm{Al}, \mathrm{K}, \mathrm{Ca}$, & $488 \mathrm{O}, 5 \mathrm{Na}, 4 \mathrm{Al}, 239 \mathrm{Si}, 2 \mathrm{~K}, 1 \mathrm{Ca}$ \\
\hline 158515(1)_pt2 & 2 & $\mathrm{PM}_{2.5}$ & Quartz & $\mathrm{O}, \mathrm{Si}$ & $\mathrm{Na}, \mathrm{Mg}, \mathrm{Al}, \mathrm{K}$ & $356 \mathrm{O}, 3 \mathrm{Na}, 3 \mathrm{Mg}, 8 \mathrm{Al}, 170 \mathrm{Si}, 1 \mathrm{~K}$ \\
\hline
\end{tabular}


Table B4. Particulate matter identification (continued)

\begin{tabular}{|c|c|c|c|c|c|c|}
\hline SEM ID number & $\begin{array}{l}\text { Site } \\
\text { number }\end{array}$ & $\begin{array}{l}\text { Particle } \\
\text { type }\end{array}$ & $\begin{array}{l}\text { Mineral } \\
\text { group }\end{array}$ & $\begin{array}{l}\text { Major } \\
\text { elements }\end{array}$ & $\begin{array}{l}\text { Minor } \\
\text { elements }\end{array}$ & Formulas from SEM data \\
\hline 158515(1)_pt3 & 2 & $\mathrm{PM}_{2.5}$ & Silicates & $\mathrm{O}, \mathrm{Si}, \mathrm{Al}, \mathrm{Fe}$ & $\begin{array}{l}\mathrm{Na}, \mathrm{Mg}, \mathrm{K}, \mathrm{Ca}, \\
\mathrm{Ti}\end{array}$ & $\begin{array}{l}417 \mathrm{O}, 5 \mathrm{Na}, 4 \mathrm{Mg}, 18 \mathrm{Al}, 164 \mathrm{Si}, 1 \mathrm{~K} \\
5 \mathrm{Ca}, 4 \mathrm{Ti}, 28 \mathrm{Fe}\end{array}$ \\
\hline 158515(1)_pt4 & 2 & $\mathrm{PM}_{2.5}$ & Quartz & $\mathrm{O}, \mathrm{Si}$ & $\begin{array}{l}\mathrm{Na}, \mathrm{Mg}, \mathrm{Al}, \mathrm{K} \\
\mathrm{Fe}\end{array}$ & $\begin{array}{l}511 \mathrm{O}, 4 \mathrm{Na}, 9 \mathrm{Mg}, 5 \mathrm{Al}, 231 \mathrm{Si}, 1 \mathrm{~K}, \\
20 \mathrm{Fe}\end{array}$ \\
\hline 158515(1)_pt6 & 2 & $\mathrm{PM}_{2.5}$ & Quartz & $\mathrm{O}, \mathrm{Si}$ & $\mathrm{Na}, \mathrm{Mg}, \mathrm{Al}, \mathrm{Ca}$ & $314 \mathrm{O}, 5 \mathrm{Na}, 1 \mathrm{Mg}, 1 \mathrm{Al}, 154 \mathrm{Si}, 1 \mathrm{Ca}$ \\
\hline 158516(1)_pt1 & 2 & $\mathrm{PM}_{2.5}$ & Quartz & $\mathrm{O}, \mathrm{Si}$ & $\mathrm{Na}, \mathrm{Al}$ & $1119 \mathrm{O}, 6 \mathrm{Na}, 1 \mathrm{Al}, 558 \mathrm{Si}$ \\
\hline 158516(1)_pt2 & 2 & $\mathrm{PM}_{2.5}$ & Quartz & $\mathrm{O}, \mathrm{Si}$ & $\mathrm{Na}$ & $224 \mathrm{O}, 1 \mathrm{Na}, 112 \mathrm{Si}$ \\
\hline 158517(1)_pt1 & 2 & $\mathrm{PM}_{2.5}$ & Quartz & $\mathrm{O}, \mathrm{Si}$ & $\mathrm{Mg}, \mathrm{Al}$ & $475 \mathrm{O}, 1 \mathrm{Mg}, 1 \mathrm{Al}, 236 \mathrm{Si}$ \\
\hline 158517(1)_pt2 & 2 & $\mathrm{PM}_{2.5}$ & Silicates & $\mathrm{O}, \mathrm{Si}, \mathrm{Fe}$ & $\mathrm{Na}, \mathrm{Mg}, \mathrm{Al}, \mathrm{K}$ & $\begin{array}{l}255 \mathrm{O}, 1 \mathrm{Na}, 2 \mathrm{Mg}, 5 \mathrm{Al}, 114 \mathrm{Si}, 1 \mathrm{~K} \\
11 \mathrm{Fe}\end{array}$ \\
\hline 158517(1)_pt3 & 2 & $\mathrm{PM}_{2.5}$ & Silicates & $\begin{array}{l}\mathrm{O}, \mathrm{Si}, \mathrm{Al}, \mathrm{Fe}, \\
\mathrm{Ca}\end{array}$ & $\mathrm{Na}, \mathrm{Mg}, \mathrm{S}, \mathrm{K}$ & $\begin{array}{l}184 \mathrm{O}, 3 \mathrm{Na}, 2 \mathrm{Mg}, 12 \mathrm{Al}, 72 \mathrm{Si}, 1 \mathrm{~S}, 1 \mathrm{~K}, \\
5 \mathrm{Ca}, 5 \mathrm{Fe}\end{array}$ \\
\hline
\end{tabular}


Table B4. Particulate matter identification (continued)

\begin{tabular}{|c|c|c|c|c|c|c|}
\hline SEM ID number & $\begin{array}{l}\text { Site } \\
\text { number }\end{array}$ & $\begin{array}{l}\text { Particle } \\
\text { type }\end{array}$ & $\begin{array}{l}\text { Mineral } \\
\text { group }\end{array}$ & $\begin{array}{l}\text { Major } \\
\text { elements }\end{array}$ & $\begin{array}{l}\text { Minor } \\
\text { elements }\end{array}$ & Formulas from SEM data \\
\hline 158517(1)_pt4 & 2 & $\mathrm{PM}_{2.5}$ & Quartz & $\mathrm{O}, \mathrm{Si}$ & $\mathrm{Na}, \mathrm{Ca}$ & $253 \mathrm{O}, 1 \mathrm{Na}, 125 \mathrm{Si}, 2 \mathrm{Ca}$ \\
\hline 158518(1)_pt1 & 2 & $\mathrm{PM}_{2.5}$ & Quartz & $\mathrm{O}, \mathrm{Si}$ & $\begin{array}{l}\mathrm{Na}, \mathrm{Mg}, \mathrm{Al}, \mathrm{K} \\
\mathrm{Ca}, \mathrm{Fe}\end{array}$ & $\begin{array}{l}294 \mathrm{O}, 3 \mathrm{Na}, 2 \mathrm{Mg}, 8 \mathrm{Al}, 132 \mathrm{Si}, 1 \mathrm{~K}, \\
1 \mathrm{Ca}, 9 \mathrm{Fe}\end{array}$ \\
\hline 158518(1)_pt2 & 2 & $\mathrm{PM}_{2.5}$ & Silicates & $\mathrm{O}, \mathrm{Si}, \mathrm{Al}$ & $\begin{array}{l}\mathrm{Na}, \mathrm{Mg}, \mathrm{K}, \mathrm{Ca}, \\
\mathrm{Fe}\end{array}$ & $\begin{array}{l}158 \mathrm{O}, 6 \mathrm{Na}, 1 \mathrm{Mg}, 10 \mathrm{Al}, 67 \mathrm{Si}, 1 \mathrm{~K}, \\
2 \mathrm{Ca}, 1 \mathrm{Fe}\end{array}$ \\
\hline 158518(1)_pt3 & 2 & $\mathrm{PM}_{2.5}$ & Quartz & $\mathrm{O}, \mathrm{Si}$ & $\begin{array}{l}\mathrm{Na}, \mathrm{Mg}, \mathrm{Al}, \mathrm{K} \\
\mathrm{Ca}, \mathrm{Fe}\end{array}$ & $\begin{array}{l}306 \mathrm{O}, 4 \mathrm{Na}, 1 \mathrm{Mg}, 12 \mathrm{Al}, 138 \mathrm{Si}, 8 \mathrm{~K} \\
2 \mathrm{Ca}, 2 \mathrm{Fe}\end{array}$ \\
\hline 6-8-15(1)_pt3 & 2 & $\mathrm{PM}_{10}$ & Quartz & $\mathrm{O}, \mathrm{Si}$ & $\mathrm{Na}, \mathrm{Al}, \mathrm{Ca}$ & $121 \mathrm{O}, 1 \mathrm{Na}, 2 \mathrm{Al}, 58 \mathrm{Si}, 1 \mathrm{Ca}$ \\
\hline 158514(2)_pt1 & 2 & $\mathrm{PM}_{10}$ & Quartz & $\mathrm{O}, \mathrm{Si}$ & $\mathrm{Na}, \mathrm{Mg}, \mathrm{Al}$ & $474 \mathrm{O}, 2 \mathrm{Na}, 1 \mathrm{Mg}, 2 \mathrm{Al}, 234 \mathrm{Si}$ \\
\hline 158514(2)_pt2 & 2 & $\mathrm{PM}_{10}$ & Quartz & $\mathrm{O}, \mathrm{Si}$ & $\begin{array}{l}\mathrm{Na}, \mathrm{Mg}, \mathrm{Al}, \mathrm{K} \\
\mathrm{Ca}, \mathrm{Fe}\end{array}$ & $\begin{array}{l}173 \mathrm{O}, 1 \mathrm{Na}, 2 \mathrm{Mg}, 6 \mathrm{Al}, 77 \mathrm{Si}, 1 \mathrm{Ki}, 1 \mathrm{Ca} \text {, } \\
4 \mathrm{Fe}\end{array}$ \\
\hline 158514(2)_pt3 & 2 & $\mathrm{PM}_{10}$ & Silicates & $\mathrm{O}, \mathrm{Si}, \mathrm{Al}$ & $\begin{array}{l}\mathrm{Na}, \mathrm{Mg}, \mathrm{K}, \mathrm{Ca} \\
\mathrm{Fe}\end{array}$ & $\begin{array}{l}158 \mathrm{O}, 3 \mathrm{Na}, 4 \mathrm{Mg}, 16 \mathrm{Al}, 62 \mathrm{Si}, 2 \mathrm{~K}, 1 \mathrm{Ca} \text {, } \\
2 \mathrm{Fe}\end{array}$ \\
\hline 158514(2)_pt4 & 2 & $\mathrm{PM}_{10}$ & Silicates & $\mathrm{O}, \mathrm{Si}, \mathrm{Na}, \mathrm{Al}$ & $\begin{array}{l}\mathrm{Mg}, \mathrm{S}, \mathrm{K}, \mathrm{Ca} \\
\mathrm{Fe}\end{array}$ & $\begin{array}{l}271 \mathrm{O}, 15 \mathrm{Na}, 1 \mathrm{Mg}, 29 \mathrm{Al}, 100 \mathrm{Si}, 2 \mathrm{~S}, \\
8 \mathrm{~K}, 5 \mathrm{Ca}, 2 \mathrm{Fe}\end{array}$ \\
\hline
\end{tabular}


Table B4. Particulate matter identification (continued)

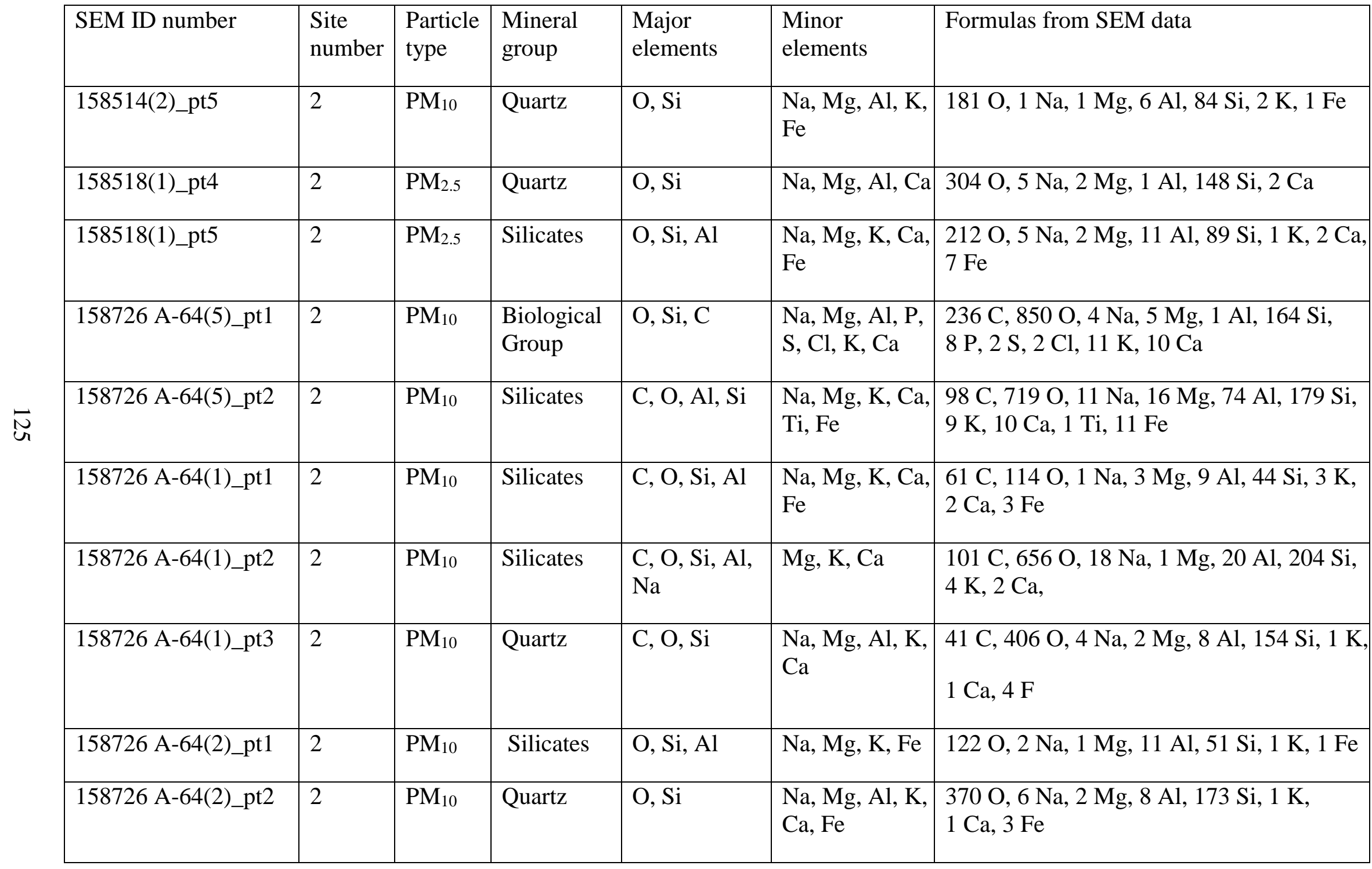


Table B4. Particulate matter identification (continued)

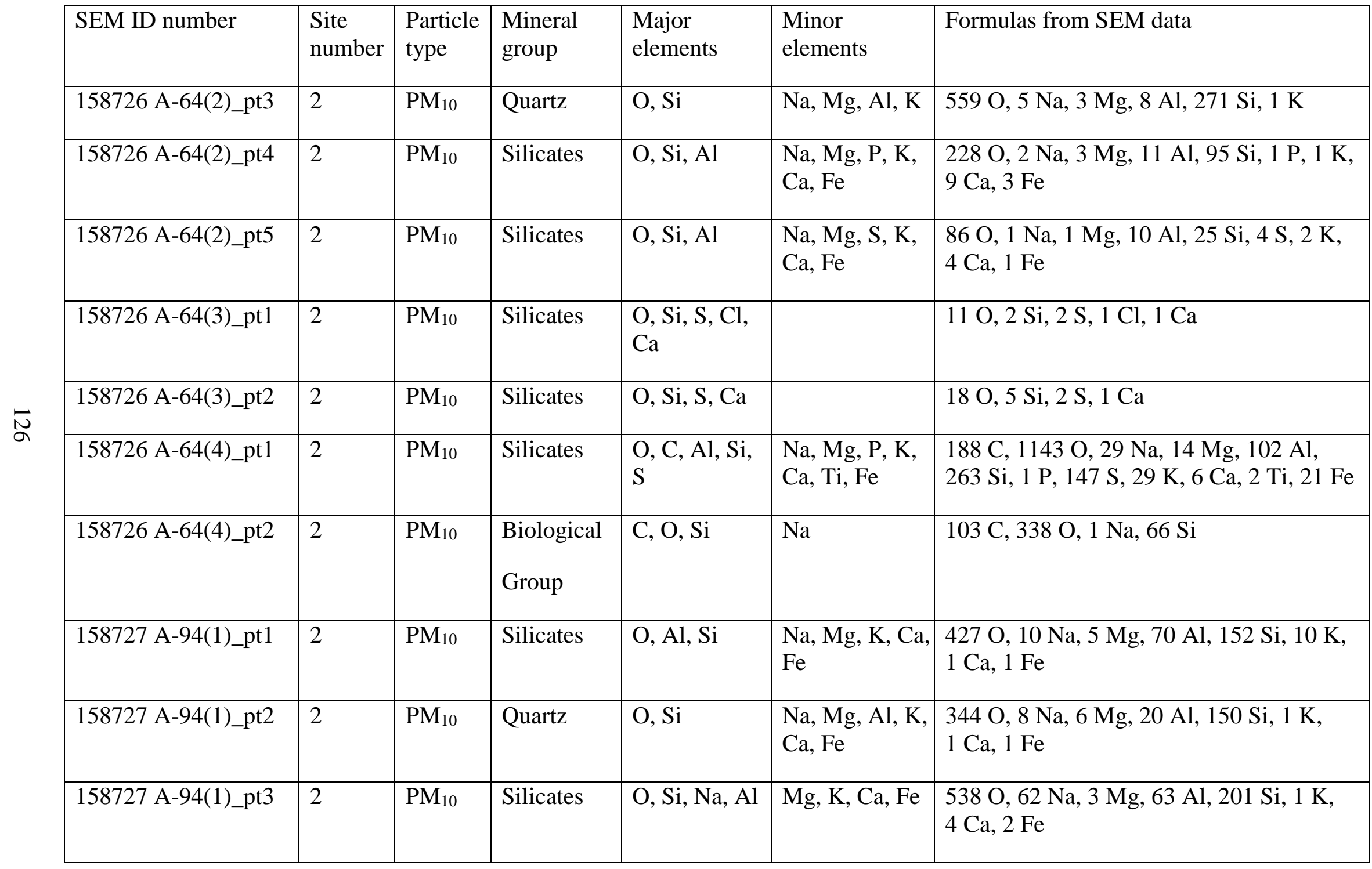


Table B4. Particulate matter identification (continued)

\begin{tabular}{|c|c|c|c|c|c|c|}
\hline SEM ID number & $\begin{array}{l}\text { Site } \\
\text { number }\end{array}$ & $\begin{array}{l}\text { Particle } \\
\text { type }\end{array}$ & $\begin{array}{l}\text { Mineral } \\
\text { group }\end{array}$ & $\begin{array}{l}\text { Major } \\
\text { elements }\end{array}$ & $\begin{array}{l}\text { Minor } \\
\text { elements }\end{array}$ & Formulas from SEM data \\
\hline 158727 A-94 (1)_pt1 & 2 & $\mathrm{PM}_{10}$ & Quartz & $\mathrm{O}, \mathrm{Si}$ & $\mathrm{Na}, \mathrm{Al}, \mathrm{Ca}$ & $379 \mathrm{O}, 1 \mathrm{Na}, 1 \mathrm{Al}, 188 \mathrm{Si}, 1 \mathrm{Ca}$ \\
\hline 158727 A-94 (1)_pt2 & 2 & $\mathrm{PM}_{10}$ & Quartz & $\mathrm{O}, \mathrm{Si}$ & $\mathrm{Na}$ & $139 \mathrm{O}, 1 \mathrm{Na}, 69 \mathrm{Si}$ \\
\hline 158727 A-94 (1)_pt3 & 2 & $\mathrm{PM}_{10}$ & Silicates & $\mathrm{O}, \mathrm{Si}, \mathrm{Ca}$ & $\mathrm{Na}, \mathrm{Mg}, \mathrm{Al}, \mathrm{Fe}$ & $\begin{array}{l}224 \mathrm{O}, 1 \mathrm{Na}, 7 \mathrm{Mg}, 3 \mathrm{Al}, 99 \mathrm{Si}, 10 \mathrm{Ca} \\
2 \mathrm{Fe}\end{array}$ \\
\hline 158727 A-94 (2)_pt1 & 2 & $\mathrm{PM}_{10}$ & Silicates & $\mathrm{O}, \mathrm{Si}, \mathrm{Al}$ & $\begin{array}{l}\mathrm{Na}, \mathrm{Mg}, \mathrm{Cl}, \mathrm{K}, \\
\mathrm{Ca}, \mathrm{Ti}, \mathrm{Fe}\end{array}$ & $\begin{array}{l}350 \mathrm{O}, 10 \mathrm{Na}, 11 \mathrm{Mg}, 37 \mathrm{Al}, 126 \mathrm{Si}, 6 \mathrm{Cl}, \\
8 \mathrm{~K}, 5 \mathrm{Ca}, 1 \mathrm{Ti}, 11 \mathrm{Fe}\end{array}$ \\
\hline 158727 A-94 (2)_pt2 & 2 & $\mathrm{PM}_{10}$ & Quartz & $\mathrm{O}, \mathrm{Si}$ & $\mathrm{Na}, \mathrm{Al}$ & $363 \mathrm{O}, 1 \mathrm{Na}, 1 \mathrm{Al}, 181 \mathrm{Si}$ \\
\hline 158727 A-94 (3)_pt3 & 2 & $\mathrm{PM}_{10}$ & Quartz & $\mathrm{O}, \mathrm{Si}$ & $\mathrm{Na}, \mathrm{Al}$ & $1119 \mathrm{O}, 7 \mathrm{Na}, 1 \mathrm{Al}, 557 \mathrm{Si}$ \\
\hline 158727 A-94 (3)_pt4 & 2 & $\mathrm{PM}_{10}$ & Silicates & $\mathrm{O}, \mathrm{Si}, \mathrm{Ca}$ & $\begin{array}{l}\mathrm{Na}, \mathrm{Mg}, \mathrm{Al}, \mathrm{K}, \\
\mathrm{Fe}\end{array}$ & $\begin{array}{l}350 \mathrm{O}, 4 \mathrm{Na}, 4 \mathrm{Mg}, 7 \mathrm{Al}, 104 \mathrm{Si}, 1 \mathrm{~K}, \\
123 \mathrm{Ca}, 2 \mathrm{Fe}\end{array}$ \\
\hline 158727 A-94 (3)_pt5 & 2 & $\mathrm{PM}_{10}$ & Oxides & $\mathrm{O}, \mathrm{Fe}$ & & $1 \mathrm{O}, 1 \mathrm{Fe}$ \\
\hline
\end{tabular}


Table B4. Particulate matter identification (continued)

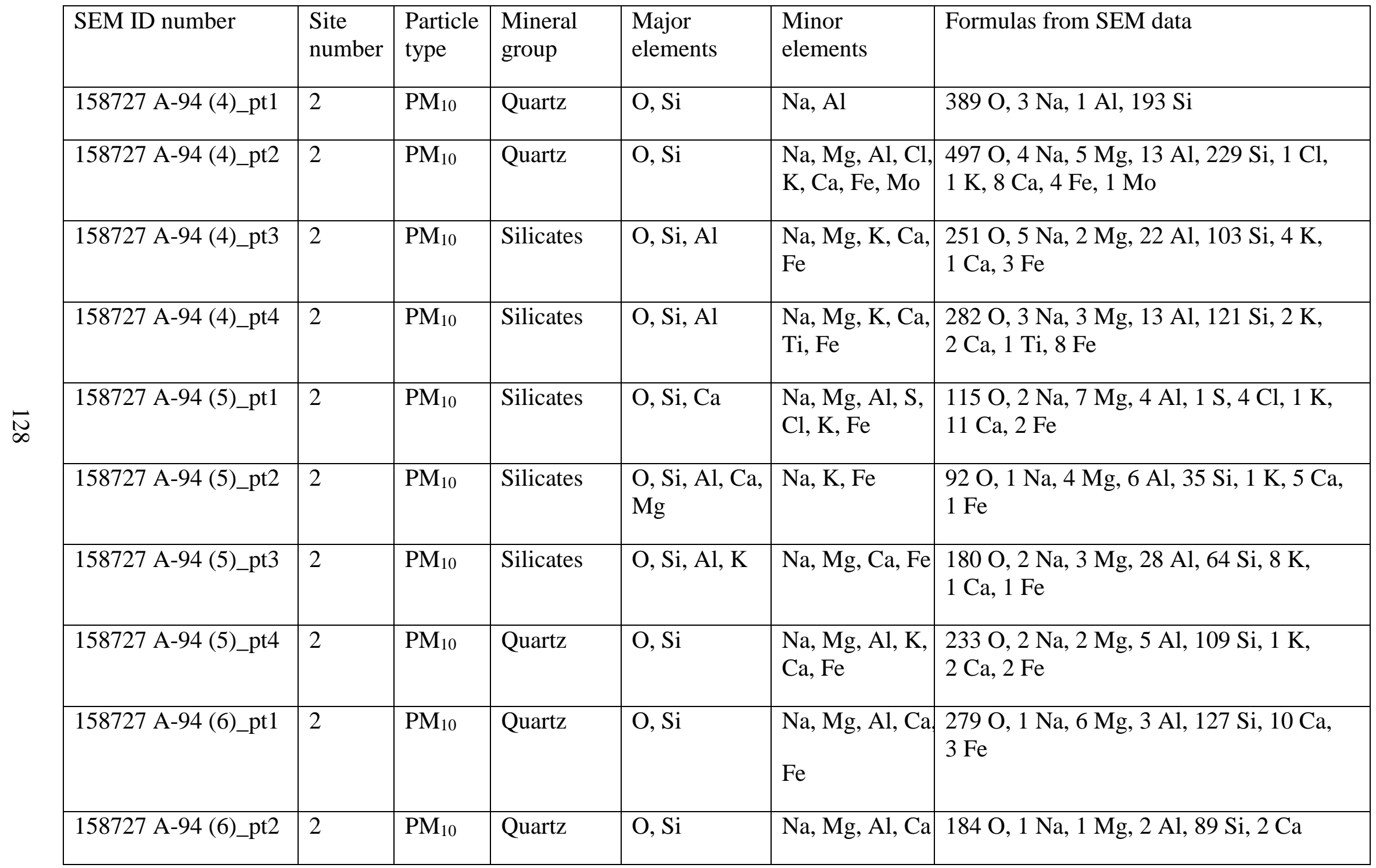


Table B4. Particulate matter identification (continued)

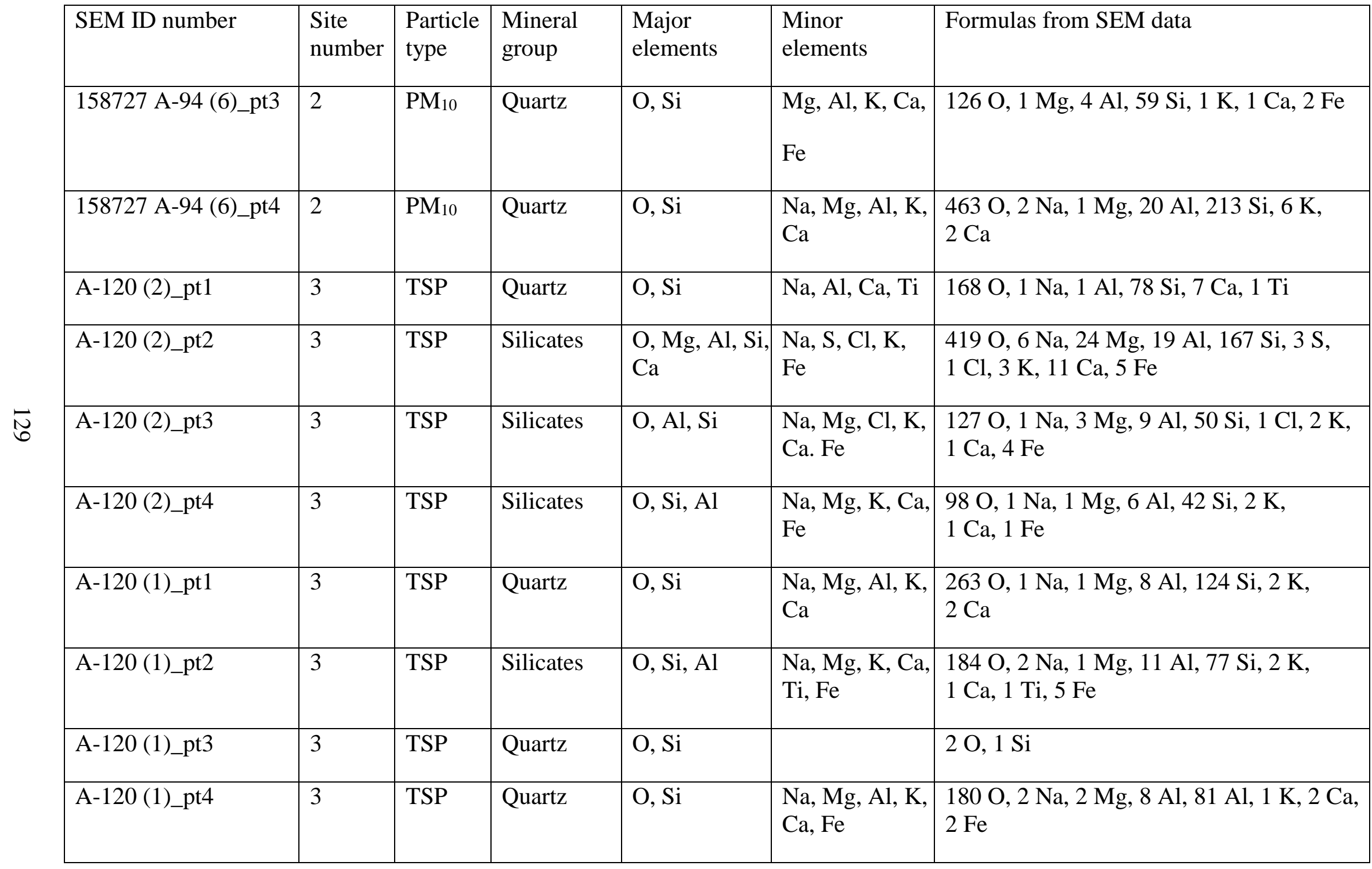


Table B4. Particulate matter identification (continued)

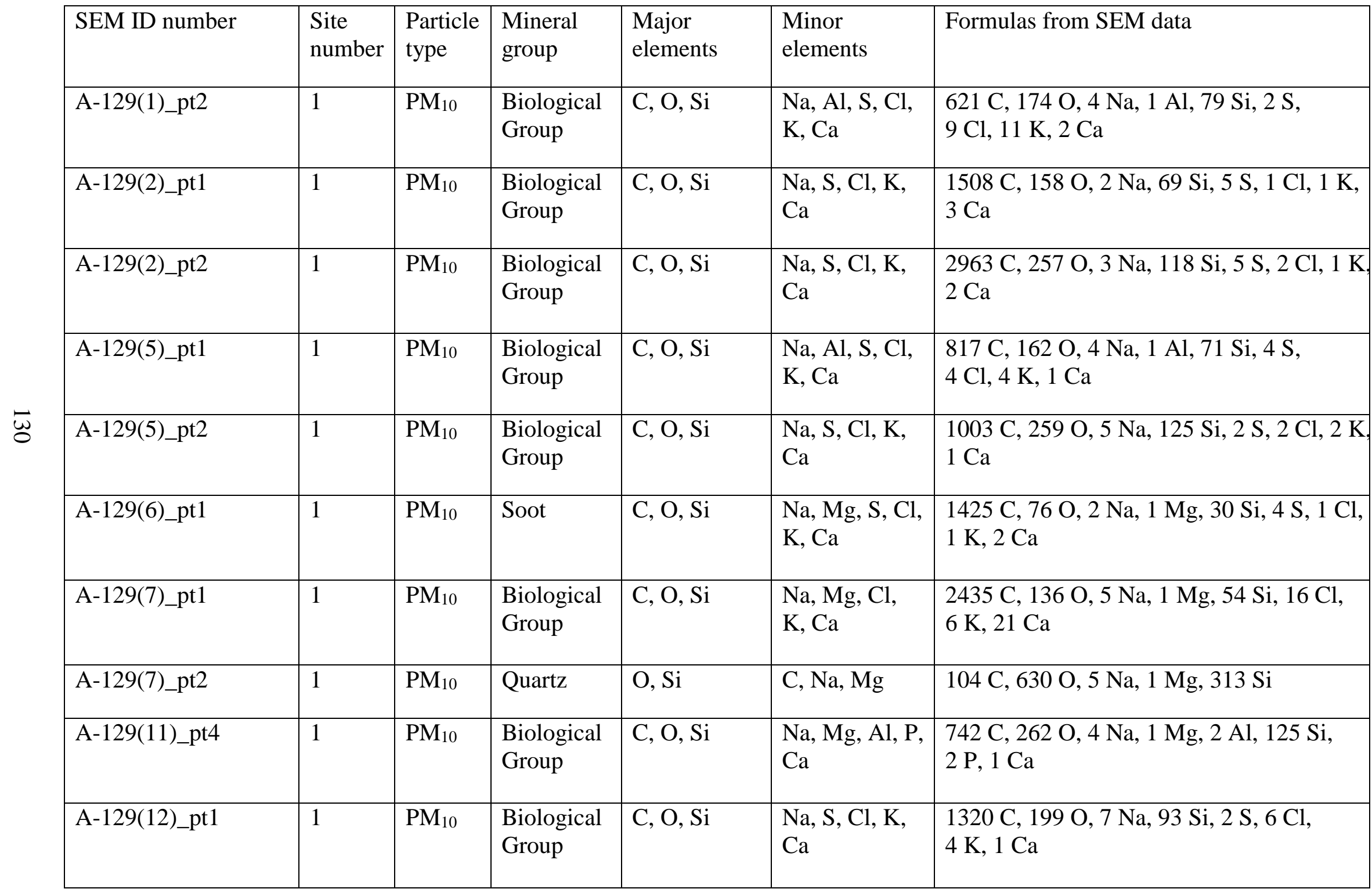


Table B4. Particulate matter identification (continued)

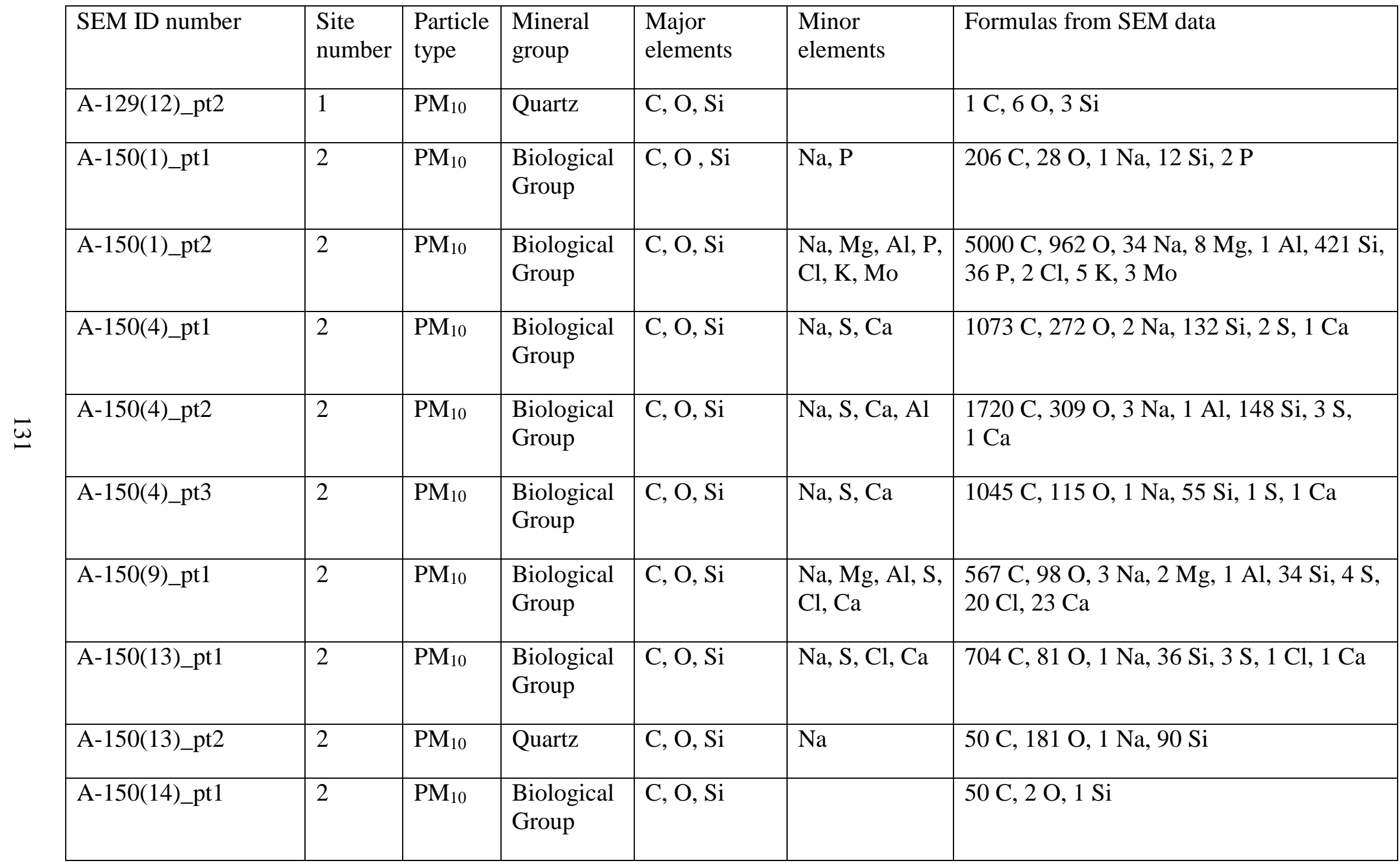


Table B4. Particulate matter identification (continued)

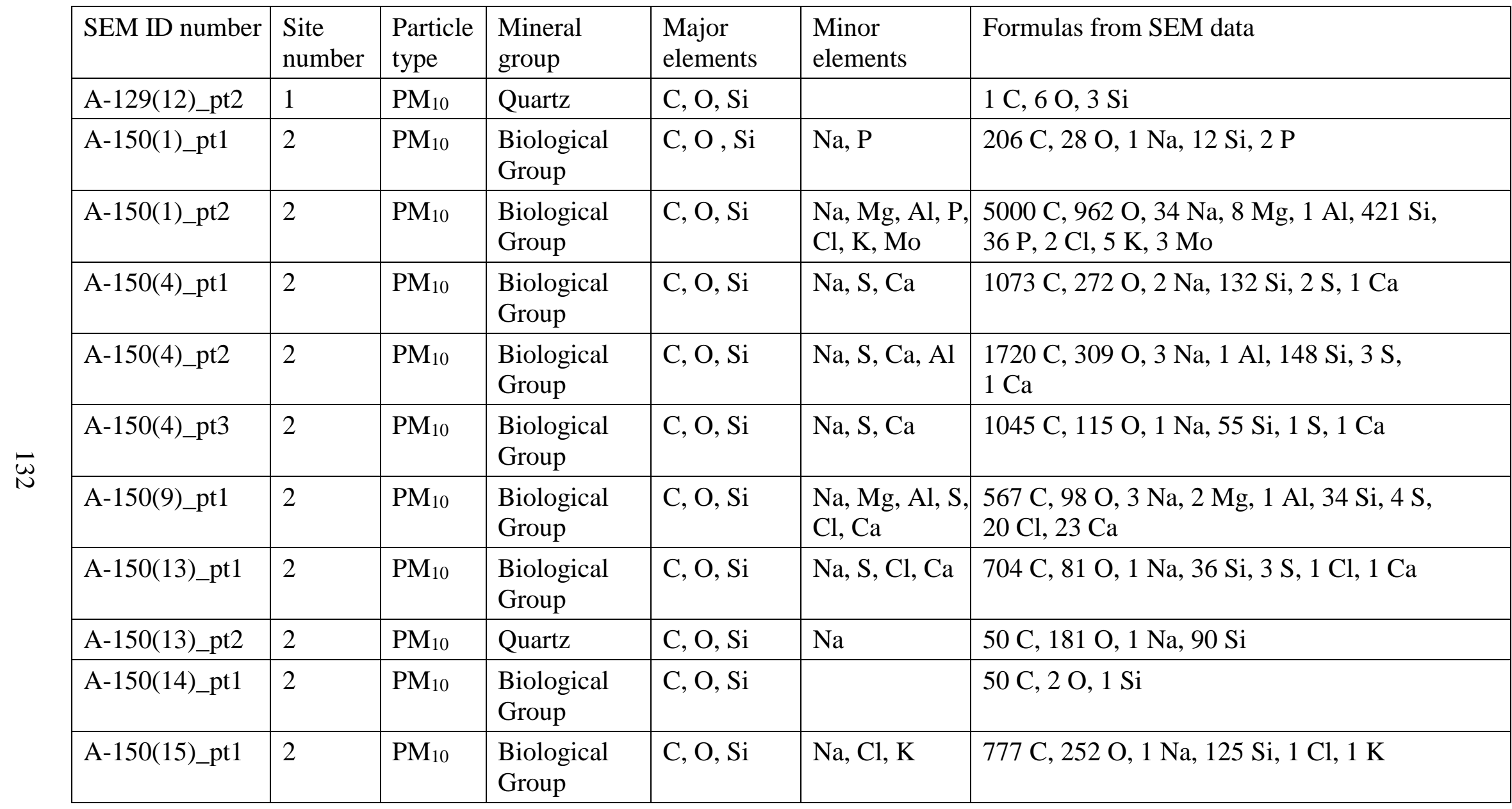




\section{APPENDIX C}

Table C1

Elemental compositions in soil samples (analyzed by ICP-MS)

\begin{tabular}{|c|c|c|c|c|c|c|c|c|c|c|}
\hline Elements & $\mathrm{Li}$ & $\mathrm{Be}$ & B & $\mathrm{Na}$ & $\mathrm{Mg}$ & $\mathrm{Al}$ & $\mathrm{P}$ & $S$ & $\mathrm{~K}$ & $\mathrm{Ca}$ \\
\hline $\begin{array}{l}\text { Unit } \\
\text { Symbol }\end{array}$ & ppm & ppm & ppm & $\%$ & $\%$ & $\%$ & $\%$ & $\%$ & $\%$ & $\%$ \\
\hline $\begin{array}{l}\text { Detection } \\
\text { Limit }\end{array}$ & 0.1 & 0.1 & 1 & 0.001 & 0.01 & 0.01 & 0.001 & 0.001 & 0.01 & 0.01 \\
\hline $\begin{array}{l}\text { Analysis } \\
\text { Method }\end{array}$ & $\begin{array}{l}\text { AR- } \\
\text { MS }\end{array}$ & $\begin{array}{l}\text { AR- } \\
\text { MS }\end{array}$ & $\begin{array}{l}\text { AR- } \\
\text { MS }\end{array}$ & $\begin{array}{l}\text { AR- } \\
\text { MS }\end{array}$ & $\begin{array}{l}\text { AR- } \\
\text { MS }\end{array}$ & $\begin{array}{l}\text { AR- } \\
\text { MS }\end{array}$ & $\begin{array}{l}\text { AR- } \\
\text { ICP }\end{array}$ & $\begin{array}{l}\text { AR- } \\
\text { ICP }\end{array}$ & $\begin{array}{l}\text { AR- } \\
\text { MS }\end{array}$ & $\begin{array}{l}\text { AR- } \\
\text { MS }\end{array}$ \\
\hline $14-\mathrm{N} 1-38$ & 15 & 0.7 & 8 & 0.044 & 0.73 & 2.66 & 0.062 & 0.048 & 0.42 & 0.44 \\
\hline $14-\mathrm{N} 2-100$ & 11.1 & 0.6 & 7 & 0.023 & 0.53 & 2.05 & 0.062 & 0.054 & 0.37 & 0.38 \\
\hline $14-\mathrm{N} 3-200$ & 10.4 & 0.6 & 5 & 0.021 & 0.51 & 2.07 & 0.059 & 0.042 & 0.34 & 0.39 \\
\hline $14-\mathrm{N} 4-300$ & 10.6 & 0.7 & 7 & 0.018 & 0.51 & 2.14 & 0.064 & 0.042 & 0.37 & 0.44 \\
\hline 14-S1-38 & 15.3 & 0.7 & 9 & 0.02 & 0.75 & 2.6 & 0.06 & 0.033 & 0.38 & 0.44 \\
\hline $14-S 2-100$ & 15.2 & 0.8 & 8 & 0.016 & 0.77 & 2.6 & 0.068 & 0.04 & 0.41 & 0.47 \\
\hline $14-S 3-200$ & 17.2 & 0.8 & 10 & 0.019 & 0.88 & 3.03 & 0.069 & 0.043 & 0.48 & 0.48 \\
\hline $14-S 4-300$ & 12.7 & 0.7 & 7 & 0.018 & 0.65 & 2.39 & 0.067 & 0.039 & 0.4 & 0.43 \\
\hline $\begin{array}{l}15-1 N 1-38- \\
1\end{array}$ & 11.2 & 0.5 & 3 & 0.019 & 0.58 & 1.69 & 0.063 & 0.046 & 0.3 & 0.53 \\
\hline $\begin{array}{l}15-1 \mathrm{~N} 1-38- \\
2\end{array}$ & 11.5 & 0.5 & 3 & 0.02 & 0.62 & 1.61 & 0.062 & 0.057 & 0.26 & 0.61 \\
\hline $\begin{array}{l}15-1 N 1-38- \\
3\end{array}$ & 11.9 & 0.5 & 3 & 0.019 & 0.63 & 1.68 & 0.074 & 0.057 & 0.31 & 0.67 \\
\hline $15-1 \mathrm{~S} 1-38-1$ & 13.5 & 0.4 & 4 & 0.064 & 0.93 & 1.51 & 0.059 & 0.107 & 0.18 & 1.48 \\
\hline $15-1 \mathrm{~S} 1-38-2$ & 16.7 & 0.5 & 4 & 0.105 & 1.17 & 1.53 & 0.063 & 0.116 & 0.16 & 1.64 \\
\hline $15-1 S 1-38-3$ & 12.6 & 0.5 & 3 & 0.061 & 0.84 & 1.46 & 0.057 & 0.077 & 0.17 & 1.31 \\
\hline $\begin{array}{l}\text { 15-1S2-100- } \\
1\end{array}$ & 14.2 & 0.6 & 4 & 0.018 & 0.74 & 2.03 & 0.069 & 0.044 & 0.34 & 0.57 \\
\hline $\begin{array}{l}15-1 S 2-100- \\
2\end{array}$ & 12.6 & 0.5 & 3 & 0.02 & 0.65 & 1.86 & 0.065 & 0.039 & 0.31 & 0.52 \\
\hline $\begin{array}{l}15-1 S 2-100- \\
3\end{array}$ & 14.8 & 0.6 & 3 & 0.018 & 0.75 & 2.05 & 0.067 & 0.041 & 0.32 & 0.54 \\
\hline
\end{tabular}


Table C1. Elemental compositions in soil samples (analyzed by ICP-MS) (continued)

\begin{tabular}{|c|c|c|c|c|c|c|c|c|c|c|}
\hline Elements & $\mathrm{Li}$ & $\mathrm{Be}$ & B & $\mathrm{Na}$ & $\mathrm{Mg}$ & $\mathrm{Al}$ & $\mathrm{P}$ & $S$ & $\mathrm{~K}$ & $\mathrm{Ca}$ \\
\hline Unit Symbol & ppm & ppm & ppm & $\%$ & $\%$ & $\%$ & $\%$ & $\%$ & $\%$ & $\%$ \\
\hline Detection Limit & 0.1 & 0.1 & 1 & 0.001 & 0.01 & 0.01 & 0.001 & 0.001 & 0.01 & 0.01 \\
\hline $15-2-\mathrm{N}-38$ & 22.2 & 1 & 5 & 0.031 & 0.76 & 2.48 & 0.07 & 0.051 & 0.31 & 0.52 \\
\hline $15-2-N-100$ & 19.5 & 0.9 & 3 & 0.03 & 0.62 & 2.33 & 0.064 & 0.042 & 0.3 & 0.38 \\
\hline $15-2-S-38$ & 23.6 & 0.9 & 4 & 0.114 & 1.12 & 2.19 & 0.059 & 0.127 & 0.16 & 1.34 \\
\hline $15-2-S-100$ & 26.5 & 1.2 & 4 & 0.026 & 0.89 & 2.9 & 0.069 & 0.039 & 0.32 & 0.45 \\
\hline $15-2-S-200$ & 26.9 & 1.2 & 5 & 0.024 & 0.89 & 2.9 & 0.072 & 0.042 & 0.33 & 0.46 \\
\hline $15-2-S-300$ & 22 & 1 & 4 & 0.029 & 0.74 & 2.57 & 0.07 & 0.039 & 0.33 & 0.41 \\
\hline $15-3-N-300$ & 14.7 & 0.7 & 1 & 0.027 & 0.49 & 1.89 & 0.064 & 0.033 & 0.25 & 0.36 \\
\hline $15-3-S-38$ & 22.6 & 0.9 & 4 & 0.074 & 0.91 & 2.15 & 0.057 & 0.115 & 0.18 & 0.93 \\
\hline $15-3-S-100$ & 23.4 & 1.1 & 4 & 0.03 & 0.78 & 2.73 & 0.069 & 0.038 & 0.33 & 0.44 \\
\hline $15-3-S-200$ & 24.2 & 1 & 4 & 0.026 & 0.81 & 2.82 & 0.072 & 0.044 & 0.35 & 0.4 \\
\hline 15-3-S-300 & 24.4 & 1.1 & 5 & 0.029 & 0.84 & 2.81 & 0.073 & 0.041 & 0.35 & 0.46 \\
\hline $15-4-N-38$ & 22.1 & 0.9 & 3 & 0.027 & 0.73 & 2.4 & 0.067 & 0.079 & 0.24 & 0.46 \\
\hline $15-4-\mathrm{N}-100$ & 17.5 & 0.8 & 2 & 0.027 & 0.57 & 2.14 & 0.063 & 0.044 & 0.27 & 0.34 \\
\hline $15-4-\mathrm{N}-200$ & 16.1 & 0.8 & 1 & 0.029 & 0.54 & 2.05 & 0.066 & 0.043 & 0.25 & 0.36 \\
\hline $15-4-N-300$ & 17.6 & 0.9 & 2 & 0.03 & 0.6 & 2.26 & 0.065 & 0.043 & 0.27 & 0.42 \\
\hline
\end{tabular}


Table C1. Elemental compositions in soil samples (analyzed by ICP-MS) (continued)

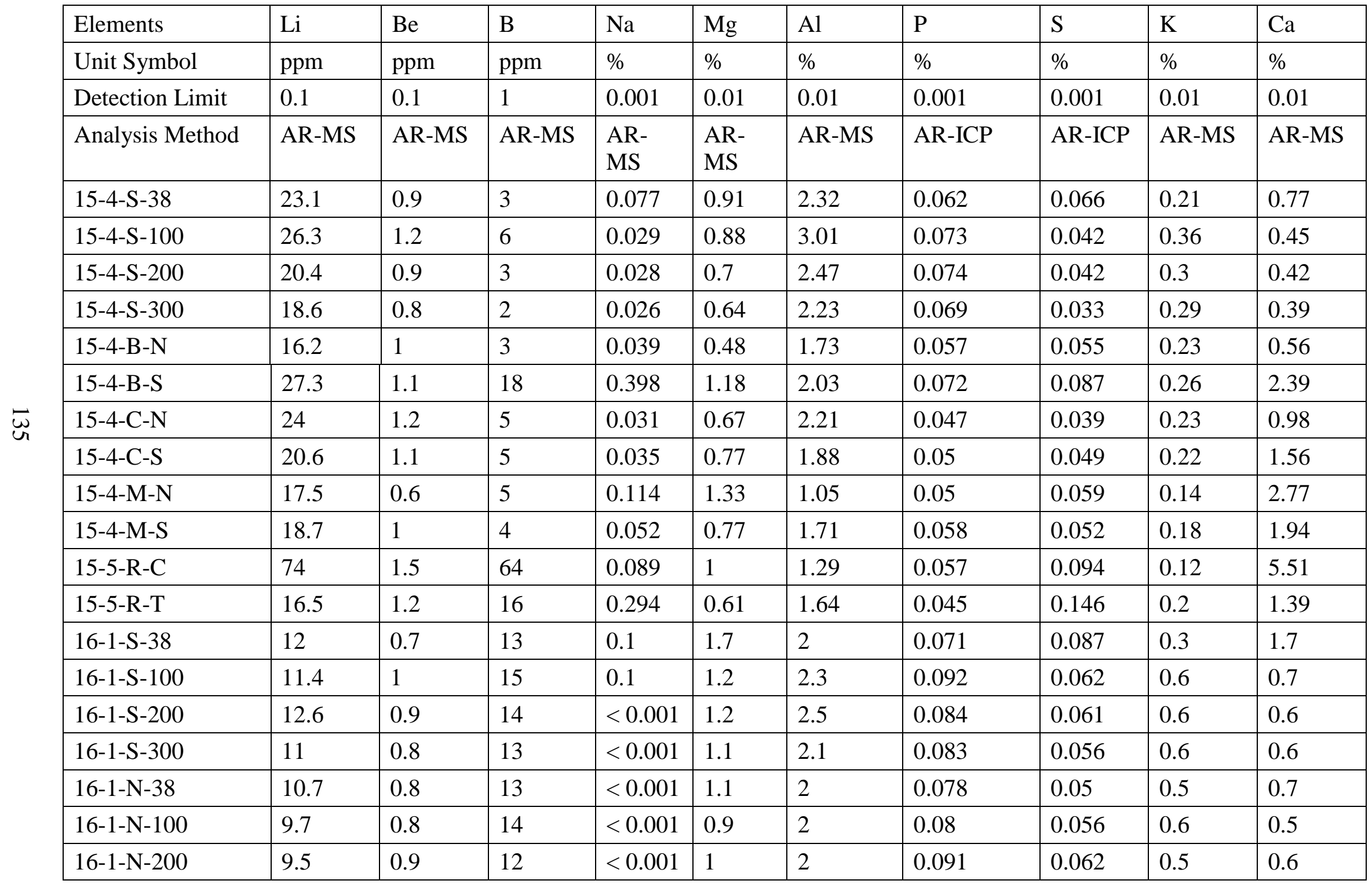


Table C1. Elemental compositions in soil samples (analyzed by ICP-MS) (continued)

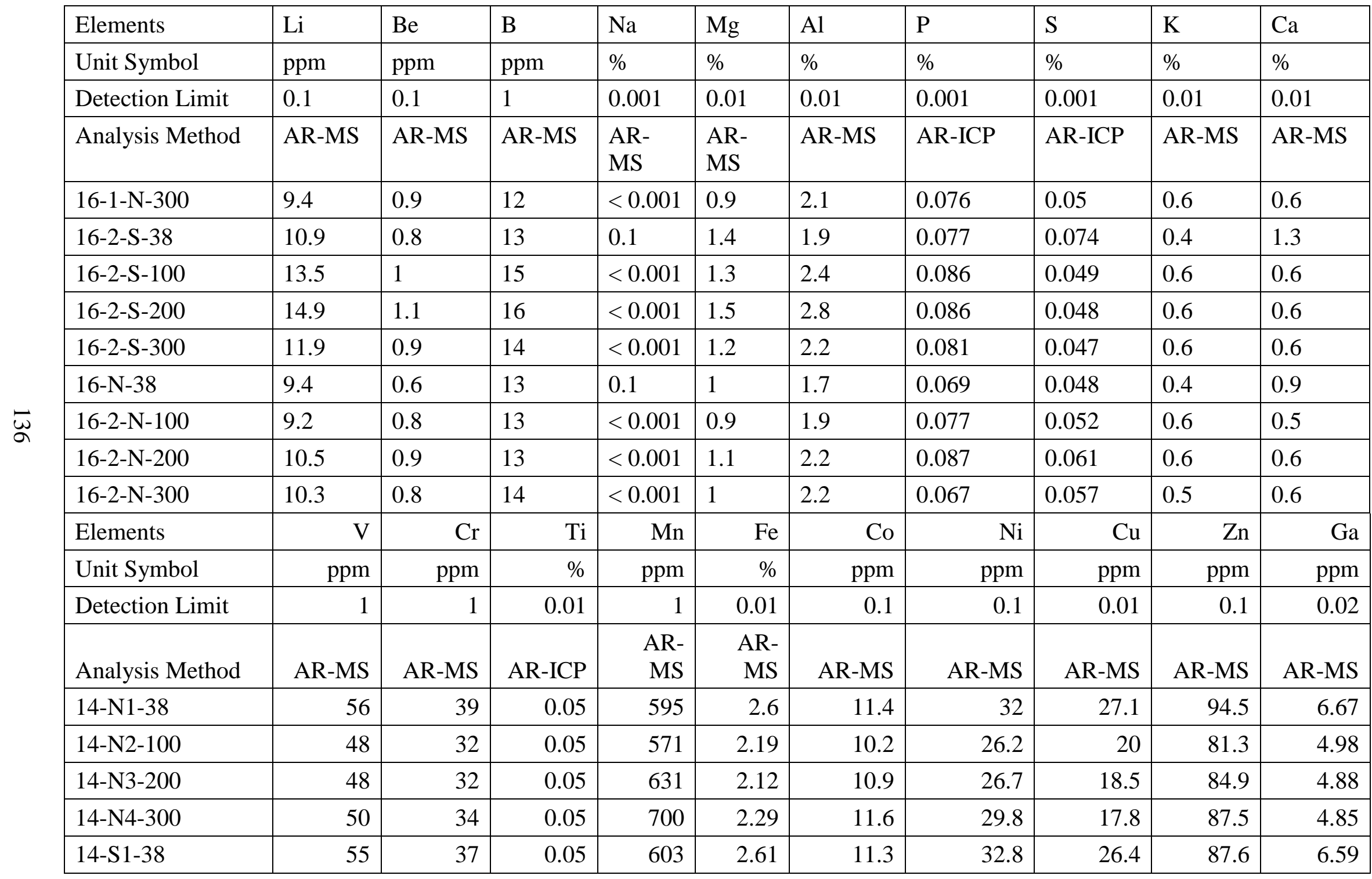


Table C1. Elemental compositions in soil samples (analyzed by ICP-MS) (continued)

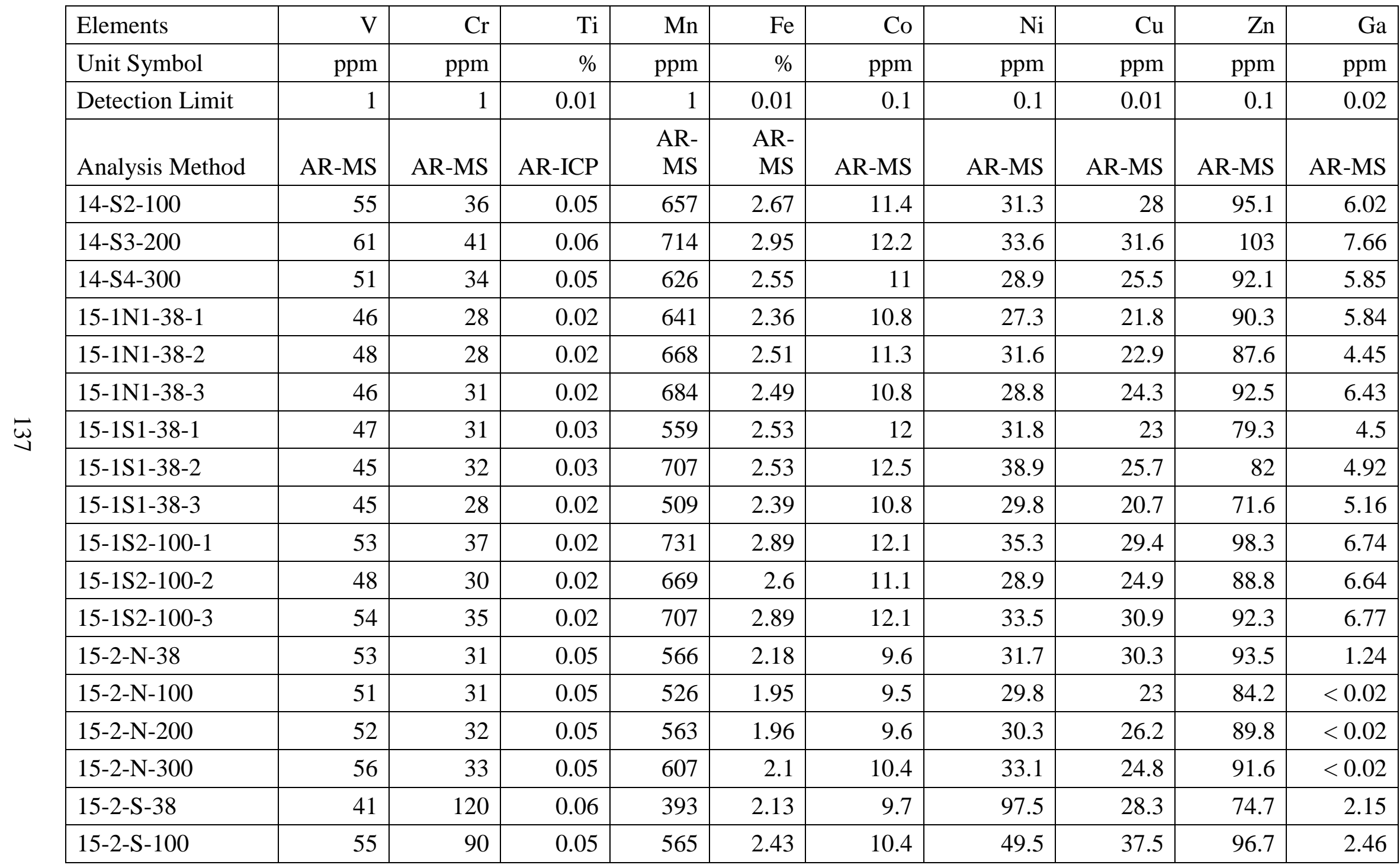


Table C1. Elemental compositions in soil samples (analyzed by ICP-MS) (continued)

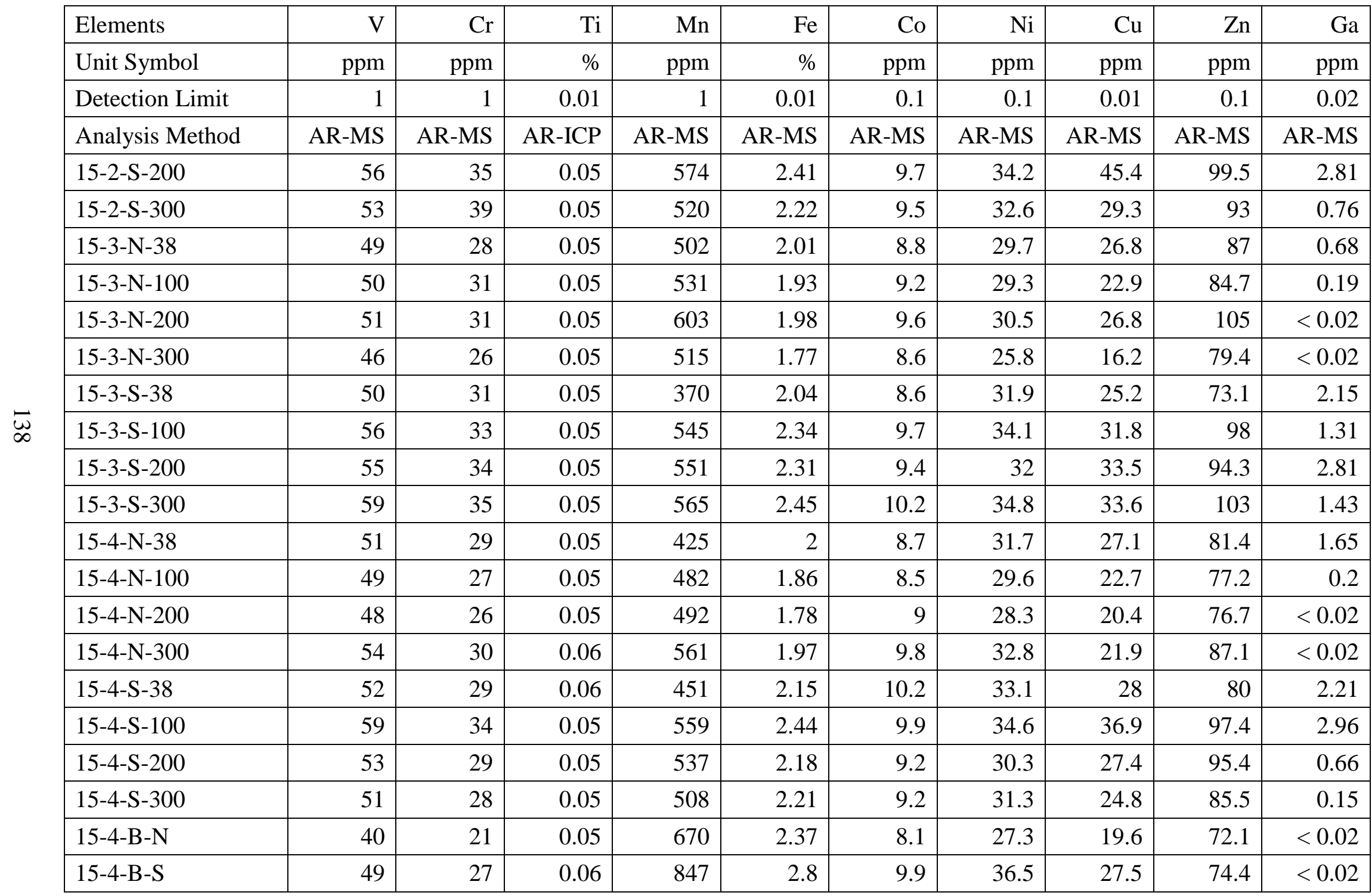


Table C1. Elemental compositions in soil samples (analyzed by ICP-MS) (continued)

\begin{tabular}{|c|c|c|c|c|c|c|c|c|c|c|}
\hline Elements & $\mathrm{V}$ & $\mathrm{Cr}$ & $\mathrm{Ti}$ & Mn & $\mathrm{Fe}$ & $\mathrm{Co}$ & $\mathrm{Ni}$ & $\mathrm{Cu}$ & $\mathrm{Zn}$ & $\mathrm{Ga}$ \\
\hline Unit Symbol & ppm & ppm & $\%$ & ppm & $\%$ & ppm & ppm & ppm & ppm & ppm \\
\hline Detection Limit & 1 & 1 & 0.01 & 1 & 0.01 & 0.1 & 0.1 & 0.01 & 0.1 & 0.02 \\
\hline $15-4-\mathrm{C}-\mathrm{N}$ & 42 & 24 & 0.05 & 526 & 2.08 & 8.3 & 27.3 & 21.1 & 63.8 & $<0.02$ \\
\hline $15-4-\mathrm{C}-\mathrm{S}$ & 40 & 22 & 0.04 & 722 & 2.96 & 8.7 & 27.3 & 20.2 & 64.6 & $<0.02$ \\
\hline $15-5-\mathrm{R}-\mathrm{C}$ & 54 & 24 & 0.04 & 2330 & 7.24 & 11.7 & 35.3 & 25.5 & 72 & $<0.02$ \\
\hline $15-5-\mathrm{R}-\mathrm{T}$ & 39 & 23 & 0.08 & 689 & 3.26 & 5 & 18.2 & 17.9 & 30.9 & $<0.02$ \\
\hline $16-1-S-38$ & 45 & 33 & 0.06 & 384 & 2.7 & 8.3 & 38.8 & 26.9 & 93.3 & 3.6 \\
\hline $16-1-S-100$ & 45 & 33 & 0.06 & 518 & 2.6 & 8.7 & 41.7 & 29.9 & 111 & 3.6 \\
\hline $16-1-\mathrm{N}-100$ & 44 & 30 & 0.06 & 483 & 2.3 & 9.1 & 47.8 & 22.5 & 100 & 3.3 \\
\hline $16-1-\mathrm{N}-200$ & 45 & 32 & 0.05 & 581 & 2.4 & 9.5 & 42.8 & 26 & 123 & 3.3 \\
\hline $16-1-\mathrm{N}-300$ & 49 & 34 & 0.05 & 601 & 2.5 & 10.2 & 39.6 & 24.3 & 115 & 3.4 \\
\hline $16-2-S-38$ & 43 & 29 & 0.06 & 368 & 2.4 & 8.2 & 46 & 23.1 & 86.3 & 3.4 \\
\hline $16-2-S-100$ & 49 & 35 & 0.06 & 511 & 2.8 & 9.5 & 42.9 & 35.2 & 110 & 4.9 \\
\hline $16-2-S-200$ & 52 & 38 & 0.06 & 513 & 3 & 9.8 & 43.5 & 38.2 & 116 & 5.3 \\
\hline 16-2-S-300 & 48 & 33 & 0.05 & 476 & 2.7 & 9.1 & 34.1 & 29.3 & 111 & 4.2 \\
\hline $16-\mathrm{N}-38$ & 41 & 27 & 0.05 & 412 & 2.2 & 7.9 & 30.9 & 21.9 & 90 & 3.3 \\
\hline $16-2-N-100$ & 44 & 29 & 0.06 & 508 & 2.3 & 9.3 & 32.8 & 25.3 & 106 & 3.5 \\
\hline
\end{tabular}


Table C1. Elemental compositions in soil samples (analyzed by ICP-MS) (continued)

\begin{tabular}{|c|c|c|c|c|c|c|c|c|c|c|}
\hline Elements & V & $\mathrm{Cr}$ & $\mathrm{Ti}$ & $\mathrm{Mn}$ & $\mathrm{Fe}$ & Co & $\mathrm{Ni}$ & $\mathrm{Cu}$ & $\mathrm{Zn}$ & $\mathrm{Ga}$ \\
\hline Unit Symbol & ppm & $\mathrm{ppm}$ & $\%$ & $\mathrm{ppm}$ & $\%$ & ppm & $\mathrm{ppm}$ & ppm & $\mathrm{ppm}$ & $\mathrm{ppm}$ \\
\hline Detection Limit & 1 & 1 & 0.01 & 1 & 0.01 & 0.1 & 0.1 & 0.01 & 0.1 & 0.02 \\
\hline $16-2-\mathrm{N}-200$ & 47 & 33 & 0.07 & 543 & 2.5 & 9.8 & 37.1 & 27.3 & 110 & 3.7 \\
\hline $16-2-\mathrm{N}-300$ & 50 & 34 & 0.06 & 552 & 2.5 & 10.2 & 41.7 & 23.6 & 106 & 3.5 \\
\hline Detection Limit & 0.1 & 0.1 & 0.1 & 0.1 & 0.5 & 0.01 & 0.1 & 0.1 & 0.1 & 0.1 \\
\hline Analysis Method & AR-MS & AR-MS & AR-MS & AR-MS & AR-MS & AR-MS & AR-MS & AR-MS & AR-MS & AR-MS \\
\hline $14-\mathrm{N} 1-38$ & $<0.1$ & 6.1 & 0.8 & 22.1 & 61.8 & 10.7 & 3.6 & 5.5 & 4.9 & 3.5 \\
\hline $14-\mathrm{N} 2-100$ & $<0.1$ & 6.1 & 0.7 & 18.2 & 64.6 & 9.91 & 2.7 & 4 & 5 & 3.3 \\
\hline $14-\mathrm{N} 3-200$ & $<0.1$ & 6 & 0.5 & 18.3 & 84.6 & 10 & 2.4 & 4.4 & 4.8 & 3.2 \\
\hline 14-S3-200 & $<0.1$ & 5.7 & 0.9 & 26.2 & 49.6 & 11.5 & 3.9 & 5.9 & 5.1 & 3.7 \\
\hline $14-S 4-300$ & $<0.1$ & 5.6 & 0.8 & 19.4 & 71.8 & 10.1 & 2.7 & 5 & 4.6 & 3.3 \\
\hline $15-1 \mathrm{~N} 1-38-1$ & 0.2 & 6.5 & 1.3 & 10.4 & 73.4 & 8.09 & 4.6 & 4.3 & 4 & 2.6 \\
\hline $15-1 \mathrm{~N} 1-38-2$ & 0.3 & 5.9 & 1.2 & 8.7 & 56.6 & 7.81 & 4 & 4.6 & 3.9 & 2.7 \\
\hline $15-1 N 1-38-3$ & 0.3 & 5.8 & 1.4 & 10.8 & 64.1 & 7.55 & 4.5 & 4 & 3.9 & 2.8 \\
\hline 15-1S1-38-1 & 0.3 & 6.2 & 0.7 & 8.5 & 79.7 & 7.99 & 4.2 & 5.4 & 4 & 2.8 \\
\hline 15-1S1-38-2 & 0.3 & 4.7 & 1.6 & 9.1 & 96.7 & 8.49 & 7.1 & 4.9 & 3.9 & 2.8 \\
\hline $15-1 S 1-38-3$ & 0.3 & 5.2 & 1.3 & 7.2 & 90.9 & 7.37 & 3.9 & 4.2 & 3.8 & 2.6 \\
\hline $15-1 S 2-100-1$ & 0.2 & 6.6 & 1.2 & 12.5 & 62.8 & 8.27 & 4.7 & 5.3 & 4.4 & 2.9 \\
\hline
\end{tabular}


Table C1. Elemental compositions in soil samples (analyzed by ICP-MS) (continued)

\begin{tabular}{|c|c|c|c|c|c|c|c|c|c|c|}
\hline Elements & $\mathrm{Ge}$ & As & $\mathrm{Se}$ & $\mathrm{Rb}$ & $\mathrm{Sr}$ & $\mathrm{Y}$ & $\mathrm{Zr}$ & $\mathrm{Sc}$ & $\mathrm{Pr}$ & $\mathrm{Gd}$ \\
\hline Unit Symbol & ppm & $\mathrm{ppm}$ & ppm & ppm & ppm & $\mathrm{ppm}$ & ppm & ppm & ppm & $\mathrm{ppm}$ \\
\hline Detection Limit & 0.1 & 0.1 & 0.1 & 0.1 & 0.5 & 0.01 & 0.1 & 0.1 & 0.1 & 0.1 \\
\hline Analysis Method & AR-MS & AR-MS & AR-MS & AR-MS & AR-MS & AR-MS & AR-MS & AR-MS & AR-MS & AR-MS \\
\hline 15-1S2-100-2 & 0.3 & 6.7 & 1.1 & 11.8 & 72.3 & 8.07 & 4.1 & 4.4 & 4 & 2.7 \\
\hline 15-1S2-100-3 & 0.3 & 6.4 & 1.1 & 12 & 64.7 & 8.39 & 4.7 & 5.3 & 4.3 & 3 \\
\hline $15-2-\mathrm{N}-38$ & $<0.1$ & 5.7 & $<0.1$ & 19.5 & 46.4 & 10.4 & 4.1 & 5.1 & 4.7 & 2.7 \\
\hline $15-2-\mathrm{N}-100$ & $<0.1$ & 6.5 & $<0.1$ & 19.5 & 61.3 & 10.2 & 2.6 & 4.7 & 5 & 2.7 \\
\hline $15-2-\mathrm{N}-200$ & $<0.1$ & 6.5 & $<0.1$ & 20 & 64 & 10.4 & 3.3 & 4.8 & 5 & 2.8 \\
\hline $15-2-\mathrm{N}-300$ & $<0.1$ & 7.5 & $<0.1$ & 19.5 & 80.8 & 11.1 & 2.5 & 5.2 & 5.1 & 2.9 \\
\hline $15-2-S-38$ & $<0.1$ & 5.1 & $<0.1$ & 13.3 & 64.5 & 9.98 & 7.6 & 5.1 & 4.4 & 2.6 \\
\hline $15-2-S-100$ & $<0.1$ & 6 & $<0.1$ & 22.5 & 41.8 & 10.7 & 3 & 5.7 & 4.9 & 2.9 \\
\hline $15-2-S-200$ & $<0.1$ & 5.6 & $<0.1$ & 23.2 & 35.1 & 10.8 & 3.9 & 5.4 & 4.9 & 2.9 \\
\hline $15-2-S-300$ & $<0.1$ & 6.2 & $<0.1$ & 20.6 & 54.6 & 10.1 & 3.2 & 5.2 & 4.6 & 2.7 \\
\hline $15-3-\mathrm{N}-38$ & $<0.1$ & 5.5 & $<0.1$ & 17.1 & 45.2 & 9.66 & 3.1 & 4.7 & 4.6 & 2.6 \\
\hline $15-3-\mathrm{N}-100$ & $<0.1$ & 6.2 & $<0.1$ & 19 & 57.4 & 10.1 & 2.7 & 4.6 & 4.9 & 2.7 \\
\hline $15-3-\mathrm{N}-200$ & $<0.1$ & 5.9 & $<0.1$ & 21.1 & 61.3 & 11 & 3.3 & 4.8 & 4.9 & 2.9 \\
\hline $15-3-N-300$ & $<0.1$ & 6.1 & $<0.1$ & 16 & 66.5 & 9.56 & 1.6 & 4.1 & 4.6 & 2.6 \\
\hline $15-3-S-38$ & $<0.1$ & 4.8 & $<0.1$ & 14.2 & 52.1 & 9.57 & 7.8 & 5 & 4.4 & 2.6 \\
\hline $15-3-S-100$ & $<0.1$ & 6.2 & $<0.1$ & 22.1 & 51 & 10.4 & 2.8 & 5.3 & 4.8 & 2.7 \\
\hline $15-3-S-200$ & $<0.1$ & 5.4 & $<0.1$ & 23.8 & 34.5 & 10 & 3.9 & 5.2 & 4.6 & 2.7 \\
\hline $15-3-S-300$ & $<0.1$ & 6.2 & $<0.1$ & 23.1 & 55 & 11.1 & 3.4 & 5.7 & 5.2 & 3 \\
\hline $15-4-N-38$ & $<0.1$ & 5.2 & $<0.1$ & 17.9 & 41.4 & 9.77 & 4.5 & 5 & 4.8 & 2.7 \\
\hline $15-4-\mathrm{N}-100$ & $<0.1$ & 6.2 & $<0.1$ & 18.5 & 53.9 & 9.52 & 2.6 & 4.4 & 4.7 & 2.6 \\
\hline $15-4-\mathrm{N}-200$ & $<0.1$ & 6.2 & $<0.1$ & 17.7 & 58.5 & 9.33 & 2.8 & 4.1 & 4.5 & 2.6 \\
\hline $15-4-N-300$ & $<0.1$ & 7 & $<0.1$ & 19.1 & 72.7 & 10.9 & 2.7 & 5 & 5.1 & 2.9 \\
\hline 15-4-S-38 & $<0.1$ & 5 & $<0.1$ & 16.2 & 57.2 & 10 & 5.7 & 5 & 4.7 & 2.8 \\
\hline $15-4-S-100$ & $<0.1$ & 6.1 & $<0.1$ & 24.6 & 37.7 & 10.7 & 3.5 & 5.8 & 4.9 & 2.9 \\
\hline
\end{tabular}


Table C1. Elemental compositions in soil samples (analyzed by ICP-MS) (continued)

\begin{tabular}{|c|c|c|c|c|c|c|c|c|c|c|}
\hline Elements & $\mathrm{Ge}$ & As & $\mathrm{Se}$ & $\mathrm{Rb}$ & $\mathrm{Sr}$ & $\mathrm{Y}$ & $\mathrm{Zr}$ & $\mathrm{Sc}$ & $\operatorname{Pr}$ & $\mathrm{Gd}$ \\
\hline Unit Symbol & ppm & ppm & $\mathrm{ppm}$ & ppm & ppm & $\mathrm{ppm}$ & $\mathrm{ppm}$ & ppm & $\mathrm{ppm}$ & $\mathrm{ppm}$ \\
\hline Detection Limit & 0.1 & 0.1 & 0.1 & 0.1 & 0.5 & 0.01 & 0.1 & 0.1 & 0.1 & 0.1 \\
\hline Analysis Method & AR-MS & AR-MS & AR-MS & AR-MS & AR-MS & AR-MS & AR-MS & AR-MS & AR-MS & AR-MS \\
\hline $15-4-S-200$ & $<0.1$ & 5.7 & $<0.1$ & 20.8 & 51.2 & 9.72 & 2.4 & 5 & 4.4 & 2.7 \\
\hline $15-4-S-300$ & $<0.1$ & 6.2 & $<0.1$ & 18.4 & 57.2 & 9.53 & 3 & 4.7 & 4.6 & 2.6 \\
\hline 15-4-B-N & $<0.1$ & 9.5 & $<0.1$ & 17.2 & 25.2 & 10.5 & 2.6 & 3.7 & 4.7 & 2.7 \\
\hline 15-4-B-S & $<0.1$ & 9.7 & $<0.1$ & 20.5 & 70.8 & 11.2 & 4.3 & 4.6 & 5 & 3 \\
\hline $15-4-\mathrm{C}-\mathrm{N}$ & $<0.1$ & 9 & $<0.1$ & 19.5 & 29.4 & 10.3 & 4.7 & 4.1 & 5.3 & 2.9 \\
\hline $15-4-\mathrm{C}-\mathrm{S}$ & $<0.1$ & 11.5 & $<0.1$ & 17.1 & 36.6 & 10 & 4.5 & 4 & 4.7 & 2.6 \\
\hline $15-4-\mathrm{M}-\mathrm{N}$ & $<0.1$ & 3.7 & $<0.1$ & 10.8 & 45.7 & 7.17 & 1.4 & 2.3 & 4.1 & 2.1 \\
\hline 15-4-M-S & $<0.1$ & 10.4 & $<0.1$ & 13.4 & 38.1 & 9.92 & 1.9 & 3.9 & 4.6 & 2.7 \\
\hline 15-5-R-C & $<0.1$ & 20 & 0.4 & 9 & 92.5 & 14.6 & 7.5 & 5.5 & 4 & 2.9 \\
\hline 15-5-R-T & $<0.1$ & 7.4 & $<0.1$ & 12.1 & 61.8 & 9.36 & 10.1 & 5.3 & 4 & 2.4 \\
\hline 16-1-S-38 & $<0.1$ & 5 & 0.2 & 9.4 & 86.9 & 13.5 & 9.8 & 6.3 & 5.6 & 2.2 \\
\hline 16-1-S-100 & $<0.1$ & 5.7 & 0.3 & 14.4 & 79 & 13.1 & 2.9 & 5.5 & 5.4 & 2.2 \\
\hline $16-1-S-200$ & $<0.1$ & 5.8 & 0.3 & 15.2 & 52 & 13 & 4.1 & 6.2 & 5.7 & 2.2 \\
\hline 16-1-S-300 & $<0.1$ & 5.7 & 0.3 & 13.3 & 77.3 & 12.2 & 3.7 & 5.8 & 4.9 & 2.1 \\
\hline $16-1-N-38$ & $<0.1$ & 5.9 & 0.3 & 12 & 56.7 & 11.5 & 5.1 & 5.7 & 4.8 & 2 \\
\hline $16-1-\mathrm{N}-100$ & $<0.1$ & 6.7 & 0.3 & 12.8 & 69.9 & 11.2 & 3.6 & 5.1 & 4.9 & 2 \\
\hline $16-1-\mathrm{N}-200$ & $<0.1$ & 6.7 & 0.5 & 14.1 & 76 & 13.1 & 5.3 & 5.3 & 5.3 & 2.1 \\
\hline $16-1-\mathrm{N}-300$ & $<0.1$ & 7.5 & 0.4 & 13.1 & 95.4 & 14.2 & 3.6 & 6.6 & 5.6 & 2.4 \\
\hline $16-2-S-38$ & $<0.1$ & 5.3 & 0.1 & 9.4 & 73.3 & 11.6 & 6.6 & 5.9 & 4.9 & 2 \\
\hline $16-2-S-100$ & $<0.1$ & 6.6 & 0.3 & 15 & 50.8 & 12.5 & 4.4 & 6.4 & 5.3 & 2.2 \\
\hline $16-2-S-200$ & $<0.1$ & 6.2 & 0.3 & 16.1 & 44.5 & 13.7 & 5 & 7.3 & 5.3 & 2.3 \\
\hline $16-2-S-300$ & $<0.1$ & 6.3 & 0.3 & 14.6 & 66.6 & 12.6 & 3.3 & 6.1 & 5.2 & 2.1 \\
\hline $16-\mathrm{N}-38$ & $<0.1$ & 6 & 0.2 & 10.3 & 64.6 & 10.8 & 3.7 & 4.9 & 4.6 & 1.8 \\
\hline $16-2-\mathrm{N}-100$ & $<0.1$ & 7.1 & 0.4 & 12.7 & 77.6 & 12.1 & 3.9 & 5.3 & 5.1 & 2.1 \\
\hline
\end{tabular}


Table C1. Elemental compositions in soil samples (analyzed by ICP-MS) (continued)

\begin{tabular}{|c|c|c|c|c|c|c|c|c|c|c|}
\hline Elements & $\mathrm{Ge}$ & As & $\mathrm{Se}$ & $\mathrm{Rb}$ & $\mathrm{Sr}$ & $\mathrm{Y}$ & $\mathrm{Zr}$ & $\mathrm{Sc}$ & $\operatorname{Pr}$ & $\mathrm{Gd}$ \\
\hline Unit Symbol & ppm & $\mathrm{ppm}$ & ppm & ppm & ppm & $\mathrm{ppm}$ & ppm & ppm & ppm & ppm \\
\hline Detection Limit & 0.1 & 0.1 & 0.1 & 0.1 & 0.5 & 0.01 & 0.1 & 0.1 & 0.1 & 0.1 \\
\hline Analysis Method & AR-MS & AR-MS & AR-MS & AR-MS & AR-MS & AR-MS & AR-MS & AR-MS & AR-MS & AR-MS \\
\hline $16-2-N-200$ & $<0.1$ & 6.8 & 0.3 & 14.7 & 77.1 & 13.4 & 3.8 & 6.2 & 5.4 & 2.3 \\
\hline $16-2-N-300$ & $<0.1$ & 8.1 & 0.3 & 13.1 & 96.9 & 14.4 & 4.1 & 6.1 & 5.6 & 2.3 \\
\hline Elements & Dy & Ho & $\mathrm{Er}$ & $\mathrm{Tm}$ & $\mathrm{Nb}$ & Mo & $\mathrm{Ag}$ & $\mathrm{Cd}$ & In & $\mathrm{Sn}$ \\
\hline Unit Symbol & ppm & ppm & $\mathrm{ppm}$ & ppm & ppm & $\mathrm{ppm}$ & ppm & ppm & ppm & ppm \\
\hline Detection Limit & 0.1 & 0.1 & 0.1 & 0.1 & 0.1 & 0.01 & 0.002 & 0.01 & 0.02 & 0.05 \\
\hline Analysis Method & AR-MS & AR-MS & AR-MS & AR-MS & AR-MS & AR-MS & AR-MS & AR-MS & AR-MS & AR-MS \\
\hline $14-\mathrm{N} 1-38$ & 2.3 & 0.4 & 1.1 & 0.2 & 0.8 & 0.9 & 0.136 & 0.35 & 0.06 & $>200$ \\
\hline $14-\mathrm{N} 2-100$ & 2.1 & 0.4 & 1.1 & 0.1 & 0.7 & 0.81 & 0.036 & 0.41 & 0.03 & 177 \\
\hline $14-\mathrm{N} 3-200$ & 2.1 & 0.4 & 1 & 0.1 & 0.6 & 0.78 & 0.046 & 0.38 & 0.03 & 32.4 \\
\hline $14-\mathrm{N} 4-300$ & 2.3 & 0.4 & 1.1 & 0.2 & 0.7 & 0.75 & 0.066 & 0.37 & 0.04 & 50.9 \\
\hline 14-S1-38 & 2.3 & 0.4 & 1.1 & 0.1 & 0.6 & 0.8 & 0.098 & 0.31 & 0.04 & 31.9 \\
\hline $14-S 2-100$ & 2.4 & 0.4 & 1.1 & 0.1 & 0.7 & 0.89 & 0.097 & 0.37 & 0.03 & 20.6 \\
\hline $14-S 3-200$ & 2.4 & 0.4 & 1.2 & 0.2 & 0.8 & 0.95 & 0.106 & 0.39 & 0.04 & 27.3 \\
\hline $14-S 4-300$ & 2.1 & 0.4 & 1 & 0.1 & 0.6 & 0.84 & 0.087 & 0.39 & 0.03 & 32.5 \\
\hline $15-1 N 1-38-1$ & 1.3 & 0.4 & 0.8 & 0.1 & 0.6 & 0.96 & 0.097 & 0.5 & 0.06 & 1.42 \\
\hline $15-1 N 1-38-2$ & 1.3 & 0.4 & 0.9 & 0.1 & 0.6 & 1.53 & 0.069 & 0.42 & $<0.02$ & 2.41 \\
\hline $15-1 N 1-38-3$ & 1.3 & 0.4 & 0.8 & 0.1 & 0.6 & 1.22 & 0.088 & 0.5 & $<0.02$ & $>200$ \\
\hline $15-1 S 1-38-1$ & 1.4 & 0.4 & 0.8 & 0.1 & 0.6 & 1.32 & 0.065 & 0.36 & $<0.02$ & 2.33 \\
\hline 15-1S1-38-2 & 1.5 & 0.4 & 0.8 & 0.1 & 0.5 & 1.17 & 0.11 & 0.38 & $<0.02$ & $>200$ \\
\hline 15-1S1-38-3 & 1.2 & 0.4 & 0.8 & 0.1 & 0.5 & 1.08 & 0.047 & 0.34 & $<0.02$ & 3.16 \\
\hline 15-1S2-100-1 & 1.5 & 0.4 & 0.9 & 0.1 & 0.6 & 1.23 & 0.069 & 0.46 & $<0.02$ & 67.1 \\
\hline $15-1 \mathrm{~S} 2-100-2$ & 1.3 & 0.4 & 0.8 & 0.1 & 0.5 & 1.11 & 0.06 & 0.4 & $<0.02$ & 1.62 \\
\hline 15-1S2-100-3 & 1.4 & 0.4 & 0.8 & 0.1 & 0.6 & 1.03 & 0.071 & 0.42 & $<0.02$ & 3.78 \\
\hline $15-2-\mathrm{N}-38$ & 2.2 & 0.4 & 1.1 & 0.1 & 1 & 1.06 & 0.332 & 0.36 & 0.03 & 18.2 \\
\hline
\end{tabular}


Table C1. Elemental compositions in soil samples (analyzed by ICP-MS) (continued)

\begin{tabular}{|c|c|c|c|c|c|c|c|c|c|c|}
\hline Elements & Dy & Ho & $\mathrm{Er}$ & $\mathrm{Tm}$ & $\mathrm{Nb}$ & Mo & $\mathrm{Ag}$ & $\mathrm{Cd}$ & In & $\mathrm{Sn}$ \\
\hline Unit Symbol & ppm & ppm & ppm & ppm & ppm & ppm & ppm & ppm & ppm & ppm \\
\hline Detection Limit & 0.1 & 0.1 & 0.1 & 0.1 & 0.1 & 0.01 & 0.002 & 0.01 & 0.02 & 0.05 \\
\hline Analysis Method & AR-MS & AR-MS & AR-MS & AR-MS & AR-MS & AR-MS & AR-MS & AR-MS & AR-MS & AR-MS \\
\hline $15-2-N-100$ & 2.2 & 0.4 & 1.1 & 0.1 & 0.8 & 0.91 & 0.179 & 0.36 & 0.03 & 2.05 \\
\hline $15-2-\mathrm{N}-200$ & 2.3 & 0.4 & 1.1 & 0.1 & 0.9 & 1.06 & 0.164 & $<0.01$ & $<0.02$ & $>200$ \\
\hline $15-2-N-300$ & 2.4 & 0.4 & 1.1 & 0.2 & 0.7 & 0.84 & 0.128 & 0.33 & 0.03 & 5.87 \\
\hline $15-2-S-38$ & 2.1 & 0.4 & 1.1 & 0.1 & 0.6 & 2.08 & 0.131 & 0.18 & $<0.02$ & 8.57 \\
\hline $15-2-S-100$ & 2.4 & 0.4 & 1.1 & 0.2 & 0.7 & 2.07 & 0.161 & $<0.01$ & $<0.02$ & $>200$ \\
\hline $15-2-S-200$ & 2.4 & 0.4 & 1.1 & 0.1 & 0.8 & 0.95 & 0.153 & 0.34 & 0.03 & 14.4 \\
\hline $15-2-S-300$ & 2.3 & 0.4 & 1.1 & 0.1 & 0.8 & 1.12 & 0.135 & 0.39 & 0.03 & 4.45 \\
\hline $15-3-\mathrm{N}-38$ & 2.2 & 0.4 & 1 & 0.1 & 0.9 & 1 & 0.138 & 1.8 & 0.11 & $>200$ \\
\hline $15-3-\mathrm{N}-100$ & 2.2 & 0.4 & 1 & 0.1 & 0.8 & 0.95 & 0.106 & 0.12 & $<0.02$ & 198 \\
\hline $15-3-\mathrm{N}-200$ & 2.4 & 0.4 & 1.1 & 0.2 & 0.8 & 0.93 & 0.108 & 0.43 & 0.02 & 13.1 \\
\hline $15-3-N-300$ & 2.1 & 0.4 & 1 & 0.1 & 0.7 & 0.76 & 0.096 & 0.29 & $<0.02$ & 13.6 \\
\hline $15-3-S-38$ & 2.1 & 0.4 & 1 & 0.1 & 0.8 & 1.35 & 0.125 & 2.41 & 0.13 & $>200$ \\
\hline 15-3-S-100 & 2.3 & 0.4 & 1.1 & 0.1 & 0.8 & 0.94 & 0.129 & $<0.01$ & $<0.02$ & 155 \\
\hline $15-3-S-200$ & 2.2 & 0.4 & 1 & 0.1 & 0.8 & 0.94 & 0.107 & 0.23 & $<0.02$ & 35.1 \\
\hline $15-3-S-300$ & 2.5 & 0.4 & 1.2 & 0.2 & 0.9 & 0.95 & 0.141 & $<0.01$ & $<0.02$ & 166 \\
\hline $15-4-N-38$ & 2.2 & 0.4 & 1 & 0.1 & 0.9 & 0.86 & 0.122 & 0.09 & $<0.02$ & 57 \\
\hline $15-4-N-100$ & 2.1 & 0.4 & 1 & 0.1 & 0.8 & 0.81 & 0.101 & 0.06 & $<0.02$ & 81.4 \\
\hline $15-4-\mathrm{N}-200$ & 2.1 & 0.4 & 1 & 0.1 & 0.7 & 0.81 & 0.135 & 0.84 & $<0.02$ & $>200$ \\
\hline $15-4-\mathrm{N}-300$ & 2.4 & 0.4 & 1.1 & 0.2 & 0.8 & 0.86 & 0.13 & 0.17 & $<0.02$ & 132 \\
\hline 15-4-S-38 & 2.3 & 0.4 & 1.1 & 0.1 & 0.8 & 1.26 & 0.142 & 0.21 & $<0.02$ & 16 \\
\hline $15-4-S-100$ & 2.4 & 0.4 & 1.1 & 0.2 & 0.9 & 0.96 & 0.14 & 0.37 & 0.04 & 1.46 \\
\hline $15-4-S-200$ & 2.2 & 0.4 & 1 & 0.1 & 0.7 & 0.94 & 0.114 & 0.38 & 0.03 & 2.12 \\
\hline $15-4-S-300$ & 2.1 & 0.4 & 1 & 0.1 & 0.7 & 0.86 & 0.111 & 0.35 & 0.03 & 1.42 \\
\hline 15-4-B-N & 2.2 & 0.4 & 1.1 & 0.1 & 0.8 & 1.29 & 0.132 & 0.35 & 0.03 & 2.9 \\
\hline
\end{tabular}


Table C1. Elemental compositions in soil samples (analyzed by ICP-MS) (continued)

\begin{tabular}{|c|c|c|c|c|c|c|c|c|c|c|}
\hline Elements & Dy & Ho & $\mathrm{Er}$ & $\mathrm{Tm}$ & $\mathrm{Nb}$ & Mo & $\mathrm{Ag}$ & $\mathrm{Cd}$ & In & $\mathrm{Sn}$ \\
\hline Unit Symbol & ppm & ppm & ppm & ppm & ppm & $\mathrm{ppm}$ & $\mathrm{ppm}$ & ppm & ppm & ppm \\
\hline Detection Limit & 0.1 & 0.1 & 0.1 & 0.1 & 0.1 & 0.01 & 0.002 & 0.01 & 0.02 & 0.05 \\
\hline Analysis Method & AR-MS & AR-MS & AR-MS & AR-MS & AR-MS & AR-MS & AR-MS & AR-MS & AR-MS & AR-MS \\
\hline $15-4-B-S$ & 2.5 & 0.4 & 1.2 & 0.2 & 1 & 1.16 & 0.141 & 0.37 & 0.02 & 1.85 \\
\hline $15-4-\mathrm{C}-\mathrm{N}$ & 2.3 & 0.4 & 1.1 & 0.1 & 0.9 & 1.02 & 0.12 & 0.28 & 0.02 & 2.5 \\
\hline 15-4-C-S & 2.1 & 0.4 & 1 & 0.1 & 0.7 & 1.34 & 0.098 & 0.25 & 0.03 & 2.79 \\
\hline 15-4-M-N & 1.6 & 0.3 & 0.8 & $<0.1$ & 0.7 & 0.56 & 0.094 & 0.17 & $<0.02$ & 0.97 \\
\hline 15-4-M-S & 2.1 & 0.4 & 1 & 0.1 & 0.7 & 1.18 & 0.1 & 0.23 & 0.03 & 4.09 \\
\hline $15-5-\mathrm{R}-\mathrm{C}$ & 2.7 & 0.5 & 1.5 & 0.2 & 0.3 & 4.1 & 0.088 & 1.97 & 0.09 & $>200$ \\
\hline 15-5-R-T & 2 & 0.3 & 0.9 & 0.1 & 0.7 & 2.46 & 0.108 & 4.55 & 0.26 & $>200$ \\
\hline $16-1-S-38$ & 1.5 & 0.3 & 0.8 & 0.3 & 1 & 1.4 & 0.2 & 0.2 & $<0.02$ & 23.7 \\
\hline 16-1-S-100 & 1.5 & 0.3 & 0.8 & 0.2 & 1 & 1.2 & 0.1 & 0.3 & $<0.02$ & 2.8 \\
\hline $16-1-S-200$ & 1.5 & 0.3 & 0.8 & 0.2 & 0.9 & 1.1 & 0.1 & 0.3 & $<0.02$ & 3.9 \\
\hline 16-1-S-300 & 1.4 & 0.3 & 0.7 & 0.2 & 0.9 & 1 & 0.1 & 0.2 & $<0.02$ & 5.5 \\
\hline $16-1-N-38$ & 1.3 & 0.3 & 0.7 & 0.2 & 1 & 1.1 & 0.1 & 0.2 & $<0.02$ & 19.3 \\
\hline $16-1-\mathrm{N}-100$ & 1.4 & 0.3 & 0.7 & 0.2 & 1 & 1.1 & 0.1 & 0.2 & $<0.02$ & 153 \\
\hline $16-1-\mathrm{N}-200$ & 1.5 & 0.3 & 0.8 & 0.2 & 0.9 & 1 & 0.1 & 0.6 & $<0.02$ & $>200$ \\
\hline $16-1-\mathrm{N}-300$ & 1.6 & 0.3 & 0.8 & 0.3 & 0.8 & 1 & 0.1 & 0.3 & $<0.02$ & 29.3 \\
\hline 16-2-S-38 & 1.3 & 0.3 & 0.7 & 0.2 & 0.9 & 1.2 & 0.1 & $<0.01$ & $<0.02$ & 165 \\
\hline $16-2-S-100$ & 1.5 & 0.3 & 0.8 & 0.2 & 0.8 & 1.3 & 0.3 & 0.3 & $<0.02$ & 69.4 \\
\hline 16-2-S-200 & 1.6 & 0.3 & 0.8 & 0.2 & 0.9 & 1.1 & 0.2 & 0.3 & $<0.02$ & 162 \\
\hline $16-2-S-300$ & 1.5 & 0.3 & 0.7 & 0.2 & 0.9 & 1.1 & 0.1 & 0.3 & $<0.02$ & 49.2 \\
\hline $16-\mathrm{N}-38$ & 1.3 & 0.3 & 0.6 & 0.2 & 0.9 & 1.1 & 0.1 & 0.2 & $<0.02$ & 42.7 \\
\hline $16-2-\mathrm{N}-100$ & 1.4 & 0.3 & 0.7 & 0.2 & 1 & 1 & 0.1 & 0.2 & $<0.02$ & 42.8 \\
\hline $16-2-\mathrm{N}-200$ & 1.5 & 0.3 & 0.8 & 0.2 & 0.9 & 1.1 & 0.1 & 0.3 & $<0.02$ & 79.1 \\
\hline $16-2-\mathrm{N}-300$ & 1.6 & 0.3 & 0.8 & 0.2 & 0.9 & 1 & 0.1 & 0.2 & $<0.02$ & 80.2 \\
\hline
\end{tabular}


Table C1. Elemental compositions in soil samples (analyzed by ICP-MS) (continued)

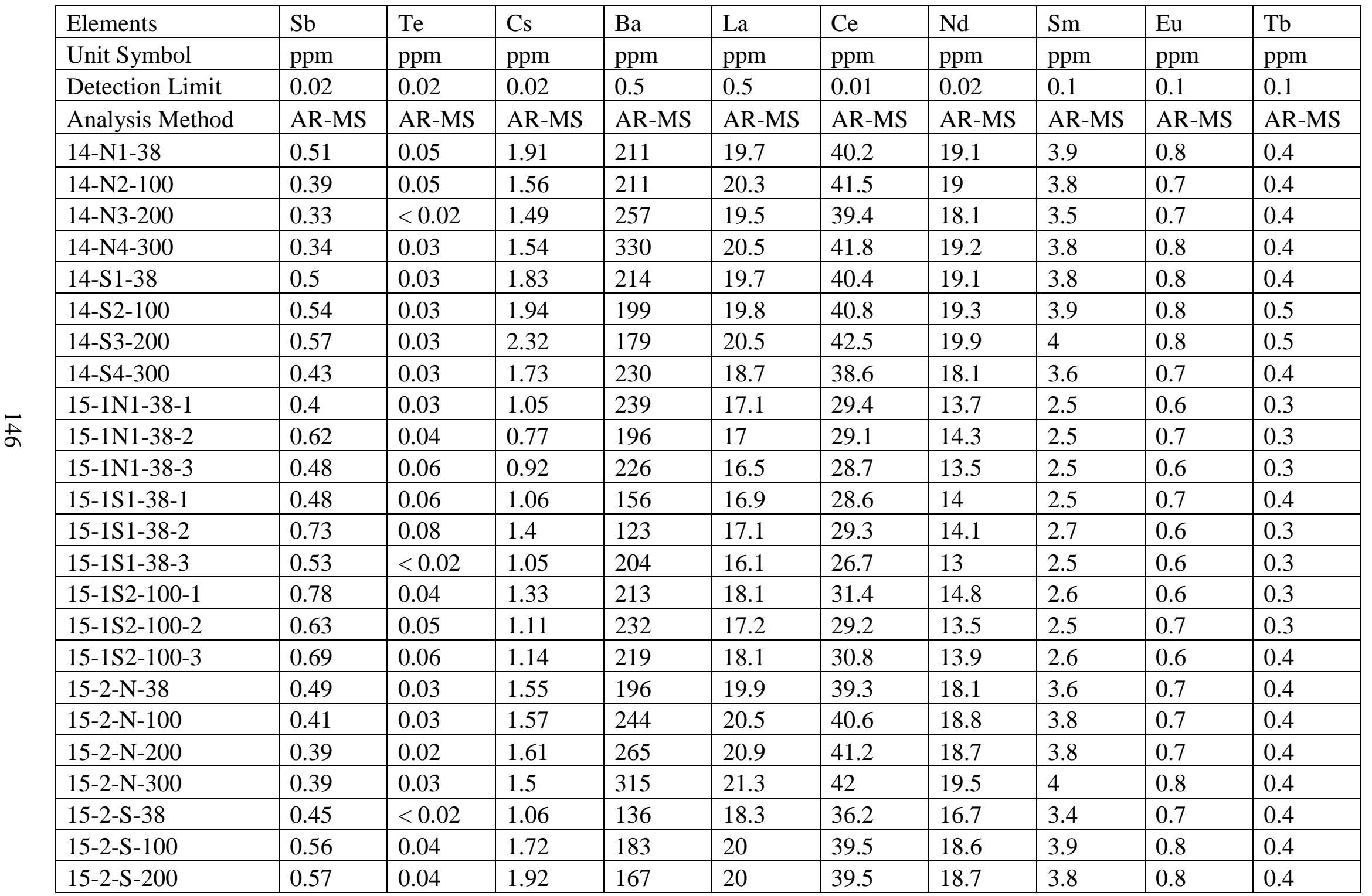


Table C1. Elemental compositions in soil samples (analyzed by ICP-MS) (continued)

\begin{tabular}{|c|c|c|c|c|c|c|c|c|c|c|}
\hline Elements & $\mathrm{Sb}$ & $\mathrm{Te}$ & Cs & $\mathrm{Ba}$ & $\mathrm{La}$ & $\mathrm{Ce}$ & $\mathrm{Nd}$ & $\mathrm{Sm}$ & $\mathrm{Eu}$ & $\mathrm{Tb}$ \\
\hline Unit Symbol & $\mathrm{ppm}$ & $\mathrm{ppm}$ & ppm & ppm & ppm & ppm & ppm & ppm & $\mathrm{ppm}$ & ppm \\
\hline Detection Limit & 0.02 & 0.02 & 0.02 & 0.5 & 0.5 & 0.01 & 0.02 & 0.1 & 0.1 & 0.1 \\
\hline Analysis Method & AR-MS & AR-MS & AR-MS & AR-MS & AR-MS & AR-MS & AR-MS & AR-MS & AR-MS & AR-MS \\
\hline $15-3-N-38$ & 0.46 & 0.03 & 1.27 & 193 & 19 & 37.7 & 17.1 & 3.6 & 0.7 & 0.4 \\
\hline $15-3-N-100$ & 0.41 & 0.02 & 1.54 & 222 & 19.7 & 39.4 & 17.9 & 3.6 & 0.7 & 0.4 \\
\hline 15-3-S-38 & 0.49 & 0.03 & 1.02 & 135 & 18.2 & 36.2 & 16.5 & 3.4 & 0.7 & 0.4 \\
\hline $15-3-S-100$ & 0.52 & 0.03 & 1.84 & 212 & 19.7 & 38.9 & 18.2 & 3.7 & 0.7 & 0.4 \\
\hline $15-3-S-200$ & 0.46 & 0.04 & 1.91 & 163 & 18.7 & 37.1 & 17.3 & 3.6 & 0.7 & 0.4 \\
\hline $15-3-S-300$ & 0.54 & 0.03 & 1.96 & 228 & 21.2 & 41.6 & 19.9 & 4 & 0.8 & 0.4 \\
\hline $15-4-\mathrm{N}-38$ & 0.45 & 0.02 & 1.33 & 173 & 20.1 & 39.4 & 17.9 & 3.6 & 0.7 & 0.4 \\
\hline $15-4-S-100$ & 0.52 & 0.03 & 1.99 & 180 & 20.4 & 40.1 & 18.9 & 4 & 0.8 & 0.4 \\
\hline $15-4-S-200$ & 0.4 & 0.03 & 1.75 & 221 & 18.5 & 36.4 & 16.8 & 3.6 & 0.7 & 0.4 \\
\hline $15-4-S-300$ & 0.42 & 0.02 & 1.53 & 231 & 19.4 & 38.4 & 17.6 & 3.5 & 0.7 & 0.4 \\
\hline $15-4-B-N$ & 0.62 & 0.02 & 1.37 & 549 & 19.1 & 38.1 & 17.7 & 3.4 & 0.7 & 0.4 \\
\hline $15-4-B-S$ & 0.73 & 0.03 & 1.89 & 435 & 20.5 & 40.1 & 18.8 & 3.9 & 0.8 & 0.4 \\
\hline $15-4-\mathrm{C}-\mathrm{N}$ & 0.57 & 0.02 & 1.61 & 389 & 21.8 & 43.3 & 20 & 4 & 0.7 & 0.4 \\
\hline 15-4-C-S & 0.69 & 0.03 & 1.38 & 618 & 19.3 & 38.3 & 17.5 & 3.5 & 0.6 & 0.4 \\
\hline 15-4-M-N & 0.33 & $<0.02$ & 1 & 242 & 17.1 & 34.3 & 15.5 & 3 & 0.5 & 0.3 \\
\hline 15-4-M-S & 0.65 & $<0.02$ & 0.9 & 642 & 18.7 & 37.1 & 17.4 & 3.7 & 0.7 & 0.4 \\
\hline 15-5-R-C & 1.15 & $<0.02$ & 0.78 & 864 & 16.6 & 33.3 & 15.7 & 3.4 & 0.7 & 0.4 \\
\hline
\end{tabular}


Table C1. Elemental compositions in soil samples (analyzed by ICP-MS) (continued)

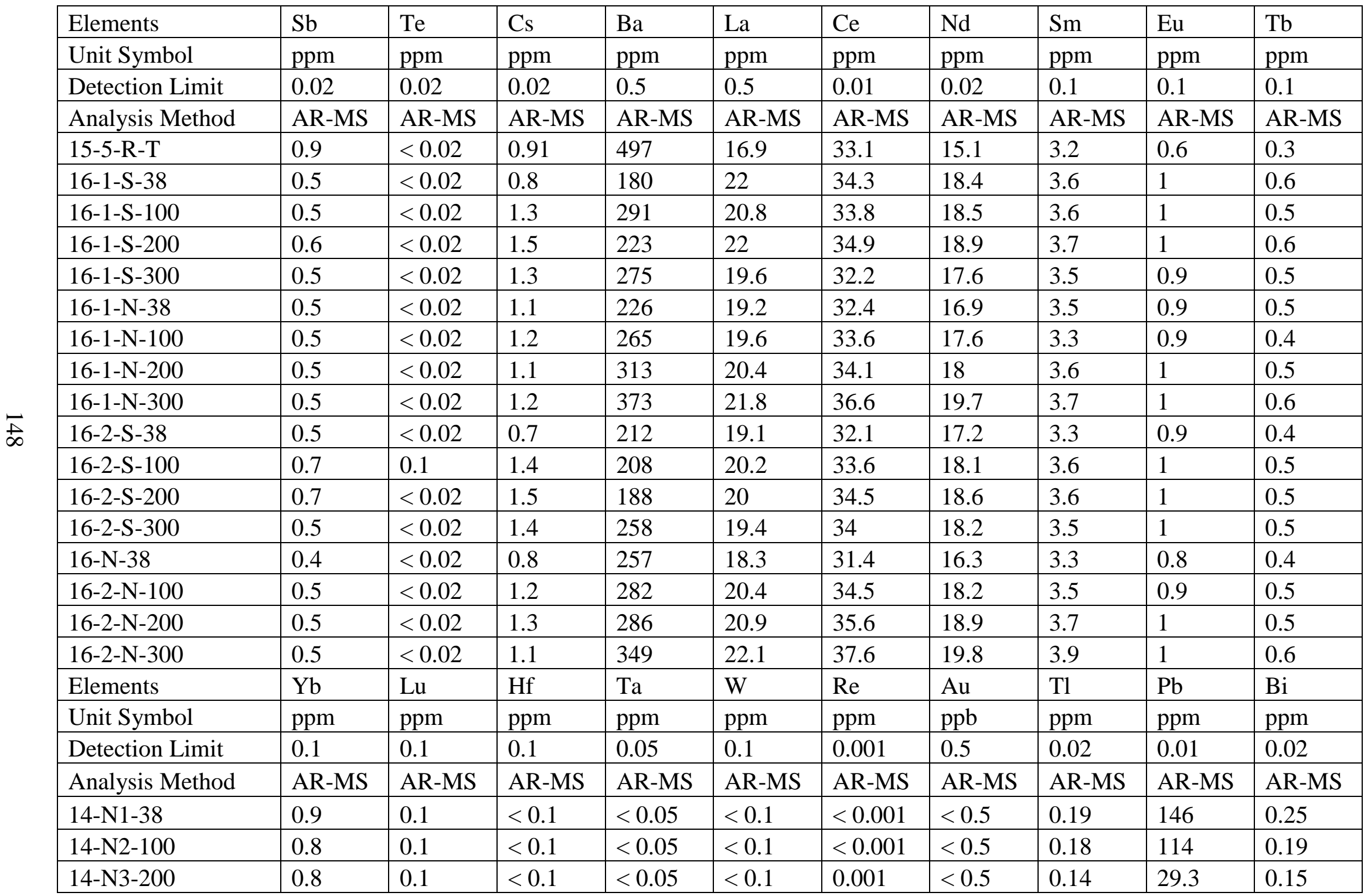


Table C1. Elemental compositions in soil samples (analyzed by ICP-MS) (continued)

\begin{tabular}{|c|c|c|c|c|c|c|c|c|c|c|}
\hline Elements & $\mathrm{Yb}$ & $\mathrm{Lu}$ & Hf & $\mathrm{Ta}$ & $\mathrm{W}$ & $\operatorname{Re}$ & $\mathrm{Au}$ & $\mathrm{Tl}$ & $\mathrm{Pb}$ & $\mathrm{Bi}$ \\
\hline Unit Symbol & ppm & $\mathrm{ppm}$ & ppm & ppm & $\mathrm{ppm}$ & ppm & $\mathrm{ppb}$ & ppm & ppm & $\mathrm{ppm}$ \\
\hline Detection Limit & 0.1 & 0.1 & 0.1 & 0.05 & 0.1 & 0.001 & 0.5 & 0.02 & 0.01 & 0.02 \\
\hline Analysis Method & AR-MS & AR-MS & AR-MS & AR-MS & AR-MS & AR-MS & AR-MS & AR-MS & AR-MS & AR-MS \\
\hline 14-S1-38 & 0.8 & 0.1 & $<0.1$ & $<0.05$ & $<0.1$ & $<0.001$ & $<0.5$ & 0.17 & 31.8 & 0.21 \\
\hline $14-S 2-100$ & 0.9 & 0.1 & $<0.1$ & $<0.05$ & $<0.1$ & 0.001 & $<0.5$ & 0.17 & 25.7 & 0.23 \\
\hline 15-1N1-38-1 & 0.6 & 0.1 & 0.1 & $<0.05$ & $<0.1$ & $<0.001$ & 1.3 & 0.16 & 46.4 & 0.2 \\
\hline $15-1 N 1-38-2$ & 0.7 & $<0.1$ & 0.1 & $<0.05$ & $<0.1$ & 0.002 & 1.4 & 0.13 & 66.9 & 0.2 \\
\hline $15-1 N 1-38-3$ & 0.7 & $<0.1$ & 0.1 & $<0.05$ & $<0.1$ & $<0.001$ & 0.6 & 0.14 & 240 & 0.25 \\
\hline 15-1S1-38-1 & 0.8 & 0.1 & $<0.1$ & $<0.05$ & $<0.1$ & 0.002 & 1.5 & 0.11 & 25.7 & 0.18 \\
\hline 15-1S1-38-2 & 0.8 & 0.1 & 0.1 & $<0.05$ & $<0.1$ & 0.002 & 3.6 & 0.12 & 1270 & 0.42 \\
\hline $15-2-N-38$ & 0.9 & 0.1 & $<0.1$ & $<0.05$ & $<0.1$ & $<0.001$ & $<0.5$ & 0.19 & 23.6 & 0.22 \\
\hline $15-2-\mathrm{N}-100$ & 0.9 & 0.1 & $<0.1$ & $<0.05$ & $<0.1$ & $<0.001$ & $<0.5$ & 0.19 & 11.9 & 0.18 \\
\hline $15-2-\mathrm{N}-200$ & 0.9 & 0.1 & $<0.1$ & $<0.05$ & $<0.1$ & $<0.001$ & $<0.5$ & 0.18 & 140 & 0.2 \\
\hline $15-2-\mathrm{N}-300$ & 1 & 0.1 & $<0.1$ & $<0.05$ & $<0.1$ & $<0.001$ & $<0.5$ & 0.19 & 13.6 & 0.17 \\
\hline $15-2-S-38$ & 0.9 & 0.1 & 0.2 & $<0.05$ & $<0.1$ & $<0.001$ & $<0.5$ & 0.17 & 14.5 & 0.16 \\
\hline $15-2-S-100$ & 1 & 0.1 & $<0.1$ & $<0.05$ & $<0.1$ & $<0.001$ & $<0.5$ & 0.21 & 126 & 0.28 \\
\hline $15-2-S-200$ & 0.9 & 0.1 & $<0.1$ & $<0.05$ & $<0.1$ & $<0.001$ & $<0.5$ & 0.22 & 23.2 & 0.27 \\
\hline $15-2-S-300$ & 0.9 & 0.1 & $<0.1$ & $<0.05$ & $<0.1$ & $<0.001$ & $<0.5$ & 0.2 & 14.1 & 0.21 \\
\hline $15-3-N-38$ & 0.8 & 0.1 & $<0.1$ & $<0.05$ & $<0.1$ & $<0.001$ & $<0.5$ & 0.17 & 171 & 0.22 \\
\hline $15-3-\mathrm{N}-100$ & 0.9 & 0.1 & $<0.1$ & $<0.05$ & $<0.1$ & $<0.001$ & $<0.5$ & 0.17 & 121 & 0.18 \\
\hline
\end{tabular}


Table C1. Elemental compositions in soil samples (analyzed by ICP-MS) (continued)

\begin{tabular}{|c|c|c|c|c|c|c|c|c|c|c|}
\hline Elements & $\mathrm{Yb}$ & $\mathrm{Lu}$ & Hf & $\mathrm{Ta}$ & $\mathrm{W}$ & $\operatorname{Re}$ & $\mathrm{Au}$ & $\mathrm{Tl}$ & $\mathrm{Pb}$ & $\mathrm{Bi}$ \\
\hline Unit Symbol & ppm & $\mathrm{ppm}$ & ppm & ppm & $\mathrm{ppm}$ & ppm & $\mathrm{ppb}$ & ppm & ppm & $\mathrm{ppm}$ \\
\hline Analysis Method & AR-MS & AR-MS & AR-MS & AR-MS & AR-MS & AR-MS & AR-MS & AR-MS & AR-MS & AR-MS \\
\hline $15-3-\mathrm{N}-300$ & 0.8 & 0.1 & $<0.1$ & $<0.05$ & $<0.1$ & $<0.001$ & $<0.5$ & 0.14 & 21.7 & 0.12 \\
\hline $15-3-S-38$ & 0.9 & 0.1 & 0.2 & $<0.05$ & $<0.1$ & $<0.001$ & $<0.5$ & 0.17 & 205 & 0.22 \\
\hline $15-3-S-300$ & 1 & 0.2 & $<0.1$ & $<0.05$ & $<0.1$ & $<0.001$ & $<0.5$ & 0.23 & 101 & 0.26 \\
\hline $15-4-N-38$ & 0.9 & 0.1 & $<0.1$ & $<0.05$ & $<0.1$ & $<0.001$ & $<0.5$ & 0.18 & 45.2 & 0.22 \\
\hline $15-4-\mathrm{N}-100$ & 0.9 & 0.1 & $<0.1$ & $<0.05$ & $<0.1$ & $<0.001$ & $<0.5$ & 0.18 & 58.5 & 0.18 \\
\hline $15-4-\mathrm{N}-200$ & 0.8 & 0.1 & $<0.1$ & $<0.05$ & $<0.1$ & $<0.001$ & $<0.5$ & 0.16 & 146 & 0.19 \\
\hline $15-4-\mathrm{N}-300$ & 1 & 0.1 & $<0.1$ & $<0.05$ & $<0.1$ & $<0.001$ & $<0.5$ & 0.18 & 87.2 & 0.19 \\
\hline 15-4-B-N & 0.9 & 0.1 & $<0.1$ & $<0.05$ & $<0.1$ & $<0.001$ & $<0.5$ & 0.2 & 13 & 0.15 \\
\hline 15-4-B-S & 1 & 0.1 & $<0.1$ & $<0.05$ & $<0.1$ & $<0.001$ & $<0.5$ & 0.24 & 14.4 & 0.23 \\
\hline $15-4-\mathrm{C}-\mathrm{N}$ & 0.9 & 0.1 & $<0.1$ & $<0.05$ & $<0.1$ & $<0.001$ & $<0.5$ & 0.22 & 12.5 & 0.2 \\
\hline 15-4-C-S & 0.9 & 0.1 & $<0.1$ & $<0.05$ & $<0.1$ & $<0.001$ & $<0.5$ & 0.2 & 11.4 & 0.18 \\
\hline 15-4-M-N & 0.6 & $<0.1$ & $<0.1$ & $<0.05$ & $<0.1$ & $<0.001$ & $<0.5$ & 0.11 & 6.4 & 0.1 \\
\hline 15-4-M-S & 0.9 & 0.1 & $<0.1$ & $<0.05$ & $<0.1$ & $<0.001$ & $<0.5$ & 0.22 & 13.5 & 0.15 \\
\hline 15-5-R-C & 1.4 & 0.2 & $<0.1$ & $<0.05$ & 0.1 & $<0.001$ & $<0.5$ & 0.19 & 174 & 0.14 \\
\hline 15-5-R-T & 0.8 & 0.1 & 0.2 & $<0.05$ & 0.2 & $<0.001$ & $<0.5$ & 0.14 & 422 & 0.24 \\
\hline 16-1-S-38 & 0.9 & 0.1 & 0.2 & $<0.05$ & 0.1 & $<0.001$ & $<0.5$ & 0.2 & 27.4 & 0.2 \\
\hline $16-1-S-100$ & 0.9 & 0.1 & 0.1 & $<0.05$ & $<0.1$ & $<0.001$ & $<0.5$ & 0.2 & 16.4 & 0.2 \\
\hline
\end{tabular}


Table C1. Elemental compositions in soil samples (analyzed by ICP-MS) (continued)

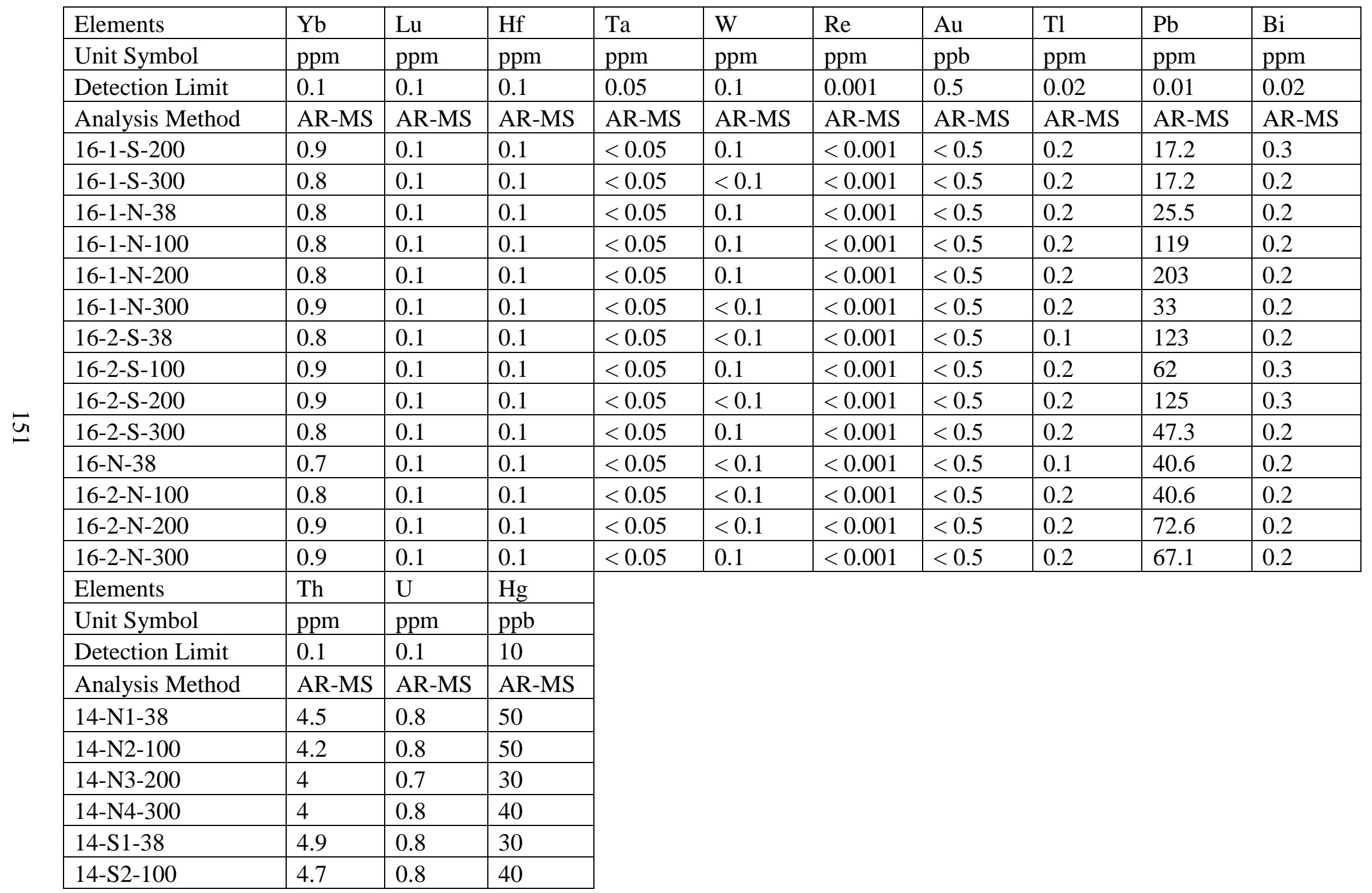


Table C1. Elemental compositions in soil samples (analyzed by ICP-MS) (continued)

\begin{tabular}{|l|l|l|l|}
\hline Elements & $\mathrm{Th}$ & $\mathrm{U}$ & $\mathrm{Hg}$ \\
\hline Unit Symbol & $\mathrm{ppm}$ & $\mathrm{ppm}$ & $\mathrm{ppb}$ \\
\hline Detection Limit & 0.1 & 0.1 & 10 \\
\hline Analysis Method & AR-MS & AR-MS & AR-MS \\
\hline $14-\mathrm{S} 3-200$ & 4.6 & 0.8 & 30 \\
\hline $14-\mathrm{S} 4-300$ & 4.1 & 0.8 & 100 \\
\hline $15-1 \mathrm{~N} 1-38-1$ & 2.9 & 0.7 & 70 \\
\hline $15-1 \mathrm{~N} 1-38-2$ & 2.7 & 0.8 & 80 \\
\hline $15-1 \mathrm{~N} 1-38-3$ & 2.7 & 0.8 & 60 \\
\hline $15-1 \mathrm{~S} 1-38-1$ & 3.7 & 1.1 & 40 \\
\hline $15-1 \mathrm{~S} 1-38-2$ & 4.9 & 1.2 & 60 \\
\hline $15-1 \mathrm{~S} 1-38-3$ & 3.4 & 0.9 & 70 \\
\hline $15-1 \mathrm{~S} 2-100-1$ & 3 & 0.8 & 60 \\
\hline $15-1 \mathrm{~S} 2-100-2$ & 2.7 & 0.7 & 40 \\
\hline $15-1 \mathrm{~S} 2-100-3$ & 2.8 & 0.8 & 30 \\
\hline $15-2-\mathrm{N}-38$ & 4.9 & 0.8 & 80 \\
\hline $15-2-\mathrm{N}-100$ & 4.6 & 0.7 & 110 \\
\hline $15-2-\mathrm{N}-200$ & 4.7 & 0.8 & 130 \\
\hline $15-2-\mathrm{N}-300$ & 4.7 & 0.8 & 140 \\
\hline $15-2-\mathrm{S}-38$ & 6.4 & 1 & 30 \\
\hline $15-2-\mathrm{S}-100$ & 5.3 & 0.7 & 100 \\
\hline $15-2-\mathrm{S}-200$ & 5.2 & 0.7 & 110 \\
\hline $15-2-\mathrm{S}-300$ & 4.6 & 0.7 & 100 \\
\hline $15-3-\mathrm{N}-38$ & 4.6 & 0.8 & 30 \\
\hline $15-3-\mathrm{N}-100$ & 4.6 & 0.7 & 20 \\
\hline $15-3-\mathrm{N}-200$ & 4.2 & 0.8 & 20 \\
\hline $15-3-\mathrm{N}-300$ & 3.9 & 0.7 & $<10$ \\
\hline $15-3-\mathrm{S}-38$ & 6 & 1 & 30 \\
\hline & & & \\
\hline
\end{tabular}


Table C1. Elemental compositions in soil samples (analyzed by ICP-MS) (continued)

\begin{tabular}{|c|c|c|c|}
\hline Elements & Th & $\mathrm{U}$ & $\mathrm{Hg}$ \\
\hline Unit Symbol & ppm & ppm & $\mathrm{ppb}$ \\
\hline Detection Limit & 0.1 & 0.1 & 10 \\
\hline Analysis Method & AR-MS & AR-MS & AR-MS \\
\hline $15-3-S-100$ & 4.8 & 0.7 & 20 \\
\hline $15-3-S-200$ & 4.7 & 0.7 & 20 \\
\hline $15-3-S-300$ & 5 & 0.8 & 20 \\
\hline $15-4-\mathrm{N}-38$ & 5.5 & 0.8 & 20 \\
\hline $15-4-\mathrm{N}-100$ & 4.5 & 0.7 & 20 \\
\hline $15-4-\mathrm{N}-200$ & 4.3 & 0.7 & 30 \\
\hline $15-4-\mathrm{N}-300$ & 5 & 0.8 & 20 \\
\hline $15-4-S-38$ & 6 & 1 & 30 \\
\hline $15-4-S-100$ & 5.4 & 0.8 & 30 \\
\hline $15-4-S-200$ & 4.2 & 0.7 & 20 \\
\hline $15-4-S-300$ & 4.5 & 0.8 & 20 \\
\hline $15-4-\mathrm{B}-\mathrm{N}$ & 4.5 & 0.9 & 20 \\
\hline $15-4-B-S$ & 5.8 & 0.9 & 30 \\
\hline $15-4-\mathrm{C}-\mathrm{N}$ & 5.8 & 0.8 & 20 \\
\hline $15-4-C-S$ & 5.4 & 1 & 20 \\
\hline 15-4-M-N & 3.8 & 0.6 & $<10$ \\
\hline 15-4-M-S & 4.7 & 0.9 & 30 \\
\hline 15-5-R-C & 4.8 & 2.8 & 30 \\
\hline 15-5-R-T & 5.5 & 1.5 & $<10$ \\
\hline $16-1-S-38$ & 5.5 & 1.3 & 70 \\
\hline $16-1-S-100$ & 3.3 & 0.9 & 50 \\
\hline 16-1-S-200 & 3.9 & 1 & 40 \\
\hline $16-1-S-300$ & 3.4 & 0.9 & 40 \\
\hline $16-1-N-38$ & 3.6 & 0.9 & 20 \\
\hline
\end{tabular}


Table C1. Elemental compositions in soil samples (analyzed by ICP-MS) (continued)

\begin{tabular}{|l|l|l|l|}
\hline Elements & $\mathrm{Th}$ & $\mathrm{U}$ & $\mathrm{Hg}$ \\
\hline Unit Symbol & $\mathrm{ppm}$ & $\mathrm{ppm}$ & $\mathrm{ppb}$ \\
\hline Detection Limit & 0.1 & 0.1 & 10 \\
\hline Analysis Method & AR-MS & AR-MS & AR-MS \\
\hline $16-1-\mathrm{N}-100$ & 3.4 & 0.8 & 30 \\
\hline $16-1-\mathrm{N}-200$ & 3 & 0.9 & 40 \\
\hline $16-1-\mathrm{N}-300$ & 3.8 & 1 & 20 \\
\hline $16-2-\mathrm{S}-38$ & 4.7 & 1 & 40 \\
\hline $16-2-\mathrm{S}-100$ & 4.1 & 0.8 & 70 \\
\hline $16-2-\mathrm{S}-200$ & 4.2 & 0.8 & 60 \\
\hline $16-2-\mathrm{S}-300$ & 3.6 & 0.9 & 40 \\
\hline $16-\mathrm{N}-38$ & 3.7 & 0.8 & 30 \\
\hline $16-2-\mathrm{N}-100$ & 3.5 & 0.8 & 30 \\
\hline \multirow{\leftarrow}{A}{} & 3.8 & 0.9 & 40 \\
\hline $16-2-\mathrm{N}-200$ & 4.1 & 0.9 & 30 \\
\hline $16-2-\mathrm{N}-300$ & & &
\end{tabular}

